UNIVERSIDADE DE SÃO PAULO - USP

FACULDADE DE DIREITO DE RIBEIRÃO PRETO

ANDRÉ SIMIONATO CASTRO

A lei de perímetro urbano e seu impacto no desenvolvimento da cidade e do campo: análise do município de Ribeirão Preto (SP)

RIBEIRÃO PRETO

2017 
ANDRÉ SIMIONATO CASTRO

A lei de perímetro urbano e seu impacto no desenvolvimento da cidade e do campo: análise do município de Ribeirão Preto (SP)

(versão original).

Dissertação apresentada ao Programa de Pós-Graduação em Direito como requisito para obtenção do título de Mestre.

Orientador: Prof. Dr.

Gustavo Assed Ferreira.

RIBEIRÃO PRETO 
Autorizo a reprodução e a divulgação parcial ou total desse trabalho, por qualquer meio convencional ou eletrônico, para fins de estudo e de pesquisa, desde que citada a fonte.

\section{Castro, André Simionato}

A lei de perímetro urbano e seu impacto no desenvolvimento da

cidade e do campo: análise do município de Ribeirão Preto (SP) / André Simionato Castro; orientador Gustavo Assed Ferreira. --

Ribeirão Preto, 2017.

$193 \mathrm{p}$.

Dissertação (Mestrado - Programa de Pós-Graduação em Direito) -Faculdade de Direito de Ribeirão Preto, Universidade de São Paulo, 2017.

1. PERIMETRO URBANO, 2. DIREITO URBANISTICO. 3. EXPANSÃO URBANA. 4. RIBEIRÃO PRETO. 5. PLANO DIRETOR. I. Ferreira, Gustavo Assed, orient. II. Título 
Dissertação de mestrado de André Simionato Castro, com o título A lei de perímetro urbano e seu impacto no desenvolvimento da cidade e do campo: análise do município de Ribeirão Preto (SP) sob orientação do Professor Doutor Gustavo Assed Ferreira Cristinai, à banca examinadora designada pelo Programa de Pós-Graduação em Direito stricto sensu - Mestrado - da Faculdade de Direito de Ribeirão Preto da Universidade de São Paulo, em $/ 2017$.

Os membros da banca examinadora consideram a candidata

Professor Doutor Gustavo Assed Ferreira

Banca Examinadora:

Professor(a) Doutor (a)

Professor (a) Doutor (a)

Professor (a) Doutor (a) 
Pelo direito à cidade. 


\section{Agradecimentos}

Aos meus pais, meu irmão e à CAPES, pelo suporte material na custosa vida de pesquisador. É cada vez mais um privilégio se dedicar à pesquisa em tempos de desmonte da Ciência e da Universidade Pública no Brasil. Ao meu orientador, Gustavo Assed, pelas valiosas dicas sobre o mundo ribeirão-pretano; Ao professor Thiago Marrara, por me fazer acreditar que a academia é possível; Ao NAJURP e todos os seus integrantes, pela oportunidade de enxergar a realidade além dos muros da universidade, e de mostrar que o direito pode fazer sentido. Em especial à professora Fabiana Severi; ao Yan Funck, pela pontualidade britânica nas reuniões e pelos debates urbanísticos; à Laysi Silva, pela dose diária de lucidez; ao Alexandre Dias, pelos cafés filosóficos; à Ana Luiza Martins, pelas caronas musicais nos domingos de trabalho; à Mariana Zan, pelo bom humor que acalenta. Aos amigos e parceiros advogados populares: Ana Mauer, Deíse Maito, Gabriela Leal, Jesus Pacheco, Júlia Navarro, Juliana Moyses, Laís Gonzalez e Tharuell Kahwage pela troca infinita de conhecimento, pela coragem de nadar contra a corrente, pelo companheirismo nas dores do crescimento e pelo profissionalismo que inspira e admira (tanto na academia quanto na labuta);Um agradecimento especial à Claudia Valente pelas madrugadas de escrita, debates, riso e desespero; pelas tentativas (frustradas) de manter a boa forma; pelas viagens acadêmicas enriquecedoras; e ,principalmente, pela amizade sincera que se faz entender só pelo olhar; Ao Arthur Escolano, pela cumplicidade nas vitórias e derrotas ao longo desses anos de mestrado e de vida.; Aos remanescentes companheiros de Turma II: Ricardo Salles, Carolina Campos, Paulinne Yshikawa, Ana Maria Assunção, Ana Laura Javaroni, Danielle Rosim - pela companhia desde a graduação e por serem a minha família em Ribeirão Preto.Às comunidades João Pessoa, Nazaré Paulista, Família e demais assentamentos de Ribeirão Preto. Espero que meu trabalho de alguma forma ajude na conquista pelo direito à cidade; à Vânia, pela paciência e profissionalismo;

À FDRP, minha eterna casa. 


\section{Resumo}

ANDRÉ, S.C. A lei de perímetro urbano e seu impacto no desenvolvimento da cidade e do campo: análise do município de Ribeirão Preto (SP) 2017, 193 fls. Dissertação de mestrado apresentada ao programa de Pós-graduação stricto sensu - Mestrado. Faculdade de Direito de Ribeirão Preto, Universidade de São Paulo. Ribeirão Preto, 2017.

A presente análise pretende entender os aspectos jurídicos e sociológicos envolvidos na produção do espaço urbano de Ribeirão Preto. O enfoque se dá em torno da lei de perímetro urbano, que tem o poder de definir o que é e o que não é cidade, moldando os destinos da geografia local e, principalmente, alterando o valor do solo sobre o qual regula. Justamente por conta dessas possibilidades, a lei é alvo de disputas das mais diversas naturezas, que por ventura desviam o instrumento de seu papel originário. Enquanto instrumento de política urbana, o perímetro urbano é previsto na Lei 10. 257 de 2001 (Estatuto da Cidade) como agente racionalizante da expansão urbana, quando essa se faz necessária. No entanto, a cidade de Ribeirão Preto presencia uma verdadeira corrida pelo ouro em sua zona rural, com "tentáculos" de grandes empreendimentos imobiliários dispersos pelo território. Isso gera a inquietação de querer descobrir se, talvez, as regras do mercado estejam prevalecendo sobre o poder normativo da lei de perímetro. É o que se pretende descrever.

Palavras chave: Regulação do Perímetro Urbano, captura econômica, Expansão Urbana, Zona Periurbana, plano diretor. 


\begin{abstract}
ANDRÉ, S.C. A lei de perímetro urbano e seu impacto no desenvolvimento da cidade e do campo: análise do município de Ribeirão Preto (SP) 2017, 193 fls. Dissertação de mestrado apresentada ao programa de Pós-graduação stricto sensu - Mestrado. Faculdade de Direito de Ribeirão Preto, Universidade de São Paulo. Ribeirão Preto, 2017

The present analysis intends to understand the legal and sociological aspects involved in the production of the urban space of Ribeirão Preto. The focus is on the law of urban perimeter, which has the power to define what is and what is not a city, shaping the destinies of local geography and also changing the value of the land over it regulates. Due to these potentialities, the law is subject of unfair disputes of various motivation, which, may distort the urban instrument from its original role. As an tool of urban policy, the urban perimeter is provided by the $10257-2001$ bill (The "City Statute") as rationalizing agent of urban expansion, when it becomes necessary. However, the city of Ribeirão Preto witnesses a gold rush in its rural area, with "tentacles" of large real estate developments scattered throughout its territory.. This raises the concern that, perhaps, market rules are prevailing over the normative power of perimeter law. This is what we want to describe
\end{abstract}

Keywords: urban Perimeter regulation, Master Plan, Urban Expansion, Peri-urban Zone, economic capture. 


\section{LISTA DE ABREVIATURAS E SIGLAS}

ABECIP- Associação Brasileira de Entidades de Crédito Imobiliário e Poupança BNH - Banco Nacional de Habitação

CEPAM - Centro de Estudos e Pesquisas de Administração Municipal

CEPEU - Centro de Pesquisas e Estudos

CNPU - Comissão Nacional de Regiões Metropolitanas e Política Urbana

CODEGRAN - Conselho Deliberativo da Grande São Paulo

COMUR - Conselho Municipal de Urbanismo de Ribeirão Preto

CONSULTI - Conselho Consultivo de Desenvolvimento Integrado da Grande São Paulo

DER - Departamento de Estradas e Rodagem do Estado de São Paulo

DOPM - Departamento de Obras Públicas do Município

DL - Decreto-Lei

DF - Distrito Federal

EESC - Escola de Engenharia de São Carlos

EMPLASA - Empresa Paulista de Planejamento Metropolitano SA

EMURB - Empresa Municipal de Urbanização de São Paulo

FUMEFI - Fundo Metropolitano de Financiamento e Investimento

GEIPOT - Grupo de Estudos para a Integração da Política de Transporte

IBAM - Instituto Brasileiro de Administração Municipal

IDORT - Instituto de Organização Racional do Trabalho de São Paulo

IAB - Instituto de Arquitetos do Brasil

IBRA - Instituto Brasileiro de Reforma Agrária

IE - Instituto de Engenharia

INCRA - Instituto Nacional de Colonização e Reforma Agrária

INPS - Instituto Nacional de Previdência Social

IPEA - Instituto de Pesquisa Econômica Aplicada

LF - Lei Federal

MDB - Movimento Democrático Brasileiro

PAR - Programa de Arrendamento Residencial

PIB - Produto Interno Bruto

PND - Plano Nacional de Desenvolvimento

RJ - Rio de Janeiro 
SBPE - Sistema Brasileiro de Poupança e Empréstimo

SEAD - Secretaria Especial de Agricultura Familiar e do Desenvolvimento Agrário SENAM - Serviço Nacional de Municípios

SERFHAU - Serviço Federal de Habitação e Urbanismo

SERPLAN - Secretaria de planejamento e Gestão Pública

SHRF - Serviço de Habitação e Reforma Urbana SP - São Paulo

SPAM - Serviço de Planejamento e Administração Metropolitana de São Paulo

SUDAM - Superintendência do Desenvolvimento da Amazônia

USP - Universidade de São Paulo 


\section{SUMÁRIO}

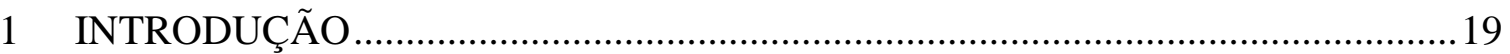

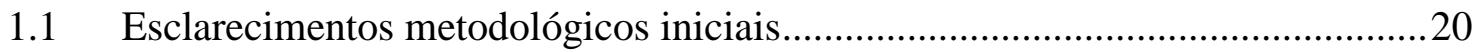

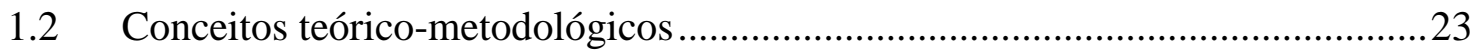

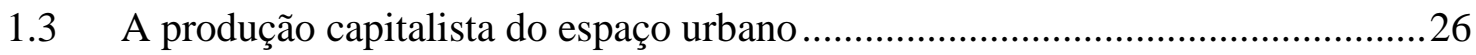

1.3.1. A origem do urbano com base em Henri Lefebvre ......................................26

1.3.2. O processo de acumulação capitalista e a necessidade de expansão territorial (com base em David Harvey) ........................................................................... 30

1.3.3. A economia política do século XXI: financeirização do solo urbano e rural 34

2 RETROSPECTIVA HISTÓRICA DA REGULAÇÃO URBANA BRASILEIRA NO

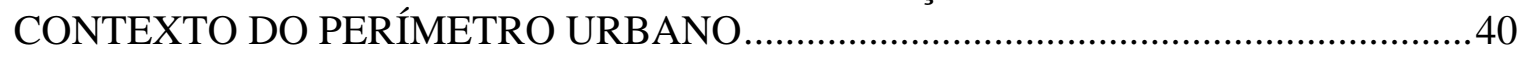

2.1 Período Colonial (1500-1822) ......................................................................... 40

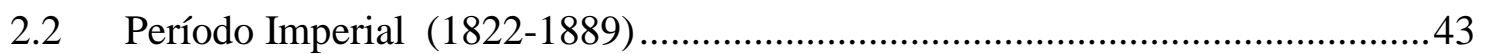

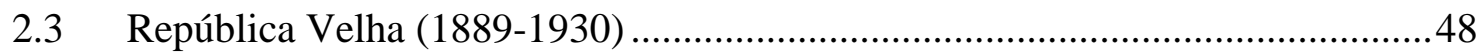

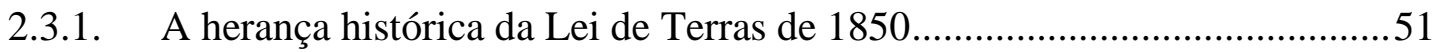

2.4 O período populista: da Era Vargas a João Goulart $(1930$ - 1964) .....................56

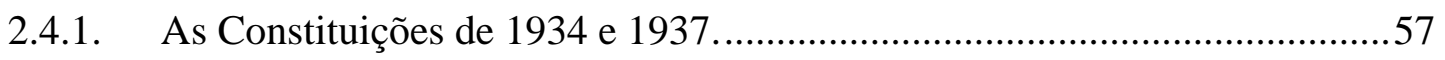

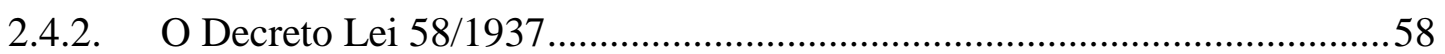

2.4.3. Habitação Social e Expansão Urbana na era Vargas ....................................60

2.4.4. O urbanismo no Pós-guerra e na Redemocratização ...................................62 62

2.4.5. O Governo JK e ascensão das empreiteiras ................................................64

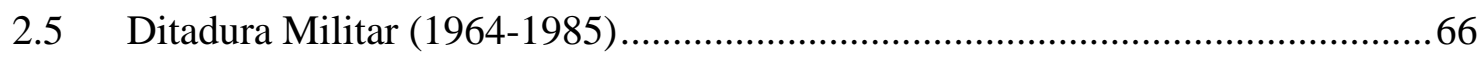

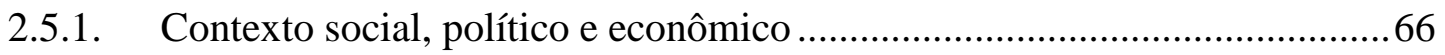

2.5.2. A administração Municipal na Constituição Federal de 1967 ...................... 71

2.5.3. A política habitacional e a influência na organização territorial urbana ......72

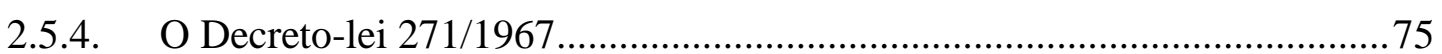

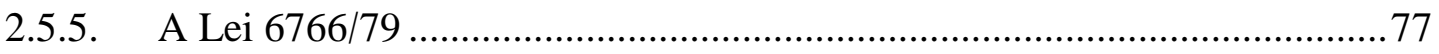

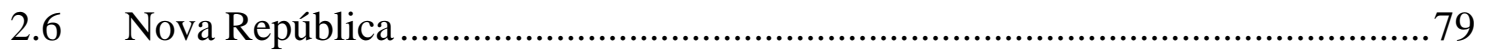

2.6.1. A política urbana na Constituição de 1988 ..................................................... 81

2.6.2. Estatuto da Cidade - o art. 42-b e a regulação do perímetro urbano .............84

2.6.3. A política habitacional em tempos de financeirização .................................89

2.6.4. A Lei $n^{\circ}$ 13.465/2017 (Medida Provisória 759 de 2016) ..............................92

3 INTERAÇÕES JURÍDICAS CONFLITUOSAS ENVOLVENDO O PERÍMETRO

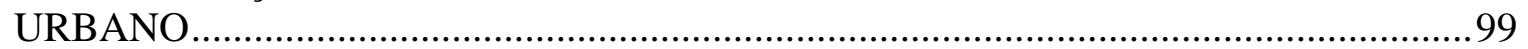

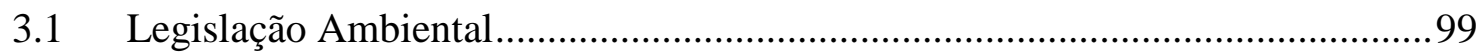

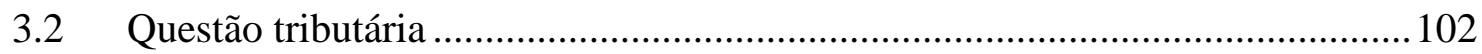

3.3 O Avanço da Cidade Sobre a Zona Rural ...................................................... 104 


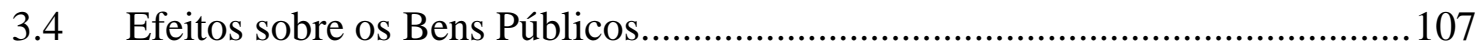

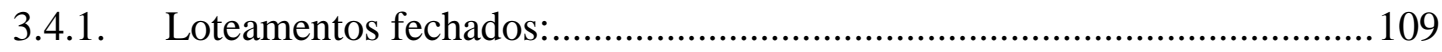

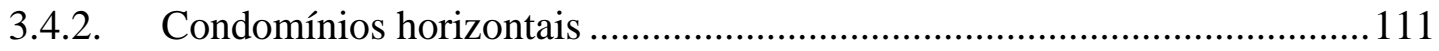

3.4.3. (Breve) Classificação dos Bens Públicos...................................................112

3.4.4. Teoria do Domínio Público..................................................................... 114

4 ANÁLISE DE CASO: A ORGANIZAÇÃO TERRITORIAL DE RIBEIRÃO PRETO 117

4.1 Ribeirão Preto no Período Colonial: expansão e primeiros regramentos...........117

4.2 República Oligárquica - a era do café. ............................................................ 120

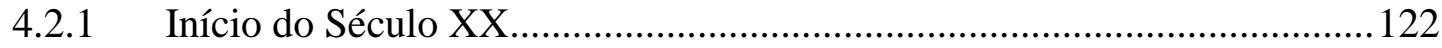

4.3 Ribeirão Preto no período populista (1930-1964) ...........................................123

4.3.1. O perímetro urbano na legislação municipal entre (1930-1964) .................... 132

4.4 Ribeirão Preto no Regime Militar (1964-1985) - A Cidade da Cana ................135

4.4.1 O perímetro urbano na legislação municipal entre (1964-1985) ....................139

4.5 Ribeirão Preto no período de redemocratização (1988-2017) ........................... 146

4.5.1. O Plano Diretor de 1995 e suas leis complementares (LC. 1.573/03 e LC.

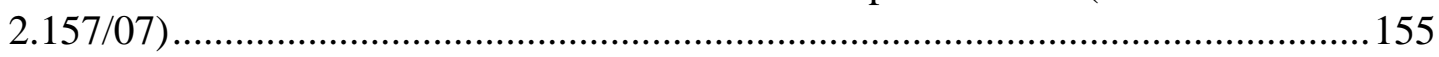

4.5.2. 4.5.3. Lei Complementar 2.505 de 2012: ADIN........................................ 159

4.5.3. A Zona de expansão Urbana e a questão Rural .......................................... 164

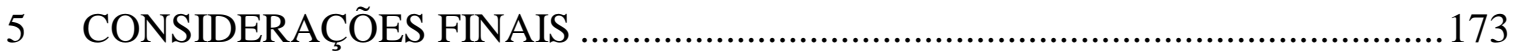

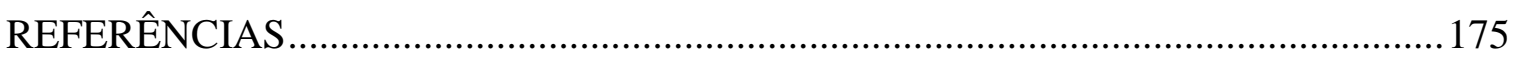

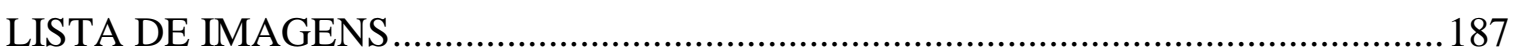




\section{INTRODUÇÃO}

O planejamento territorial brasileiro enfrenta permanentemente o desafio de gerir territórios que convertem suas terras rurais em urbanas, resultado no crescimento da cidade. A cautela nesse processo se justifica porquanto é comum o desencadeamento de atividades nocivas de especulação imobiliária permeados de conflitos jurídicos incompatíveis com o desenvolvimento inclusivo e sustentável, previsto na Constituição Federal e no Estatuto da Cidade. Ainda, o crescimento horizontal continua intenso nas cidades brasileiras após a grande explosão demográfica da industrialização, colocando tanto os aglomerados urbanos como os vazios rurais no centro de acirradas disputas de interesses. Nesse contexto, observou-se que após os anos 70 e a introdução do corolário neoliberal pelo consenso de Washington (1989) ${ }^{1}$, houve uma mudança paradigmática do papel do Estado quanto à gestão desse recurso e dos direitos a ele vinculados .(HARVEY, 2008). A privatização e a financeirização, típicas desse novo modelo, tornaram ainda mais incisivas a acumulação por extração de ativos até então considerados públicos, com o objetivo de abrir aos “investidores” campos antes excluídos do cálculo da lucratividade. (ROYER, 2013).

Autores como David Harvey (2005) demonstram como diversos tipos de utilidade, espaços e direitos públicos vem sendo privatizados em alguma medida por todo mundo capitalista, geralmente em detrimento do bem-estar da população mais vulnerável, o que instiga a busca pela compreensão dessa nova realidade socioespacial. Nessa tarefa, o filósofo Giogio Agamben (2010) postula que não se está diante de um processo de crescimento e desenvolvimento da antiga cidade, calcada na praça pública, mas da instauração de um novo paradigma intermediário.

\footnotetext{
"Certamente, um dos seus traços evidentes é que há uma passagem do modelo de polis fundada sobre um centro, no qual há um espaço público, uma ágora, para uma nova espacialização metropolitana, na qual certamente está ocorrendo um processo de 'despolitização', cujo resultado é uma curiosa zona em que não é possível decidir o que é privado e o que é público"
}

\footnotetext{
${ }^{1} \mathrm{O}$ banco mundial promovou a ideia de que governos deveriam ser menos interventivos a adotar políticas que permitam o livre funcionamento dos mercados , inclusive no que tange à política territorial; (...)(i) desenvolvimento de direitos de propriedade: Assegurando os direitos de livre troca dos bens, sob pena de punição da lei em caso de inadimplencia; um sistema registral que dê segurança para a posse; (ii) desenvolvimento de um sistema de financiamento hipotecário: criando hipotecas saudáveis e competitivas. Instituições de crédito que promovam mecanismos inovadores para fornecer maior oferta de acesso ao financiamento da habitação pelos pobres; (iii) racionalização de subsídios: garantir que os programas de subsídio sejam de escala acessível, bem segmentada, mensurável e transparente para que se evite distorcer os mercados imobiliários (tradução livre). BANCO MUNDIAL. Housing: Enabling Markets to Work.. The International Bank for Reconstruction and Development. Washinton, 2013. P.5
} 
Com o intuito de aproximar essa investigação da realidade próxima, escolheu-se a cidade de Ribeirão Preto como locus por motivos tanto pessoais como cientificamente oportunos. Primeiramente porque a literatura ainda é majoritariamente baseada nos fenômenos urbanos envolvendo cidades como Rio de Janeiro e São Paulo. Autores como Paula Santoro (2012); Nabil Bonduki (2009) e Graziano da Silva (1997) mostram que as dinâmicas da relação urbano-rural do interior são bastante peculiares e demandam uma "interiorização" da academia.

Em segundo lugar, a "Califórnia brasileira" possui uma extensa zona rural onde se testemunha a presença cada vez mais maciça de condomínio urbanísticos, criando um mosaico de bairros-enclave dispersos sobre o território. A paisagem na zona sul mescla avenidas cortando canaviais com avenidas emparedadas por muros de residenciais fechados, fazendo do espaço público mera passagem para os destinos privados. Ao analisar o mapa da lei de uso e ocupação do solo vigente (L.C. 2.157 de 2007), percebeu-se a demarcação de uma zona de expansão urbana especialmente ampla ao redor dessa região, o que levou a questionar se havia justificativa técnica para essa conformação vez que a legislação vigente não permite o contrário (assim versam o art. 42b do Estatuto da Cidade e o $\operatorname{art} .5^{\circ}$ da Lei de uso e ocupação do solo de Ribeirão Preto).

Com base nessas inquietações, a presente pesquisa indaga se existe uma captura econômica dos instrumentos jurídico-urbanísticos dedicados à definição do perímetro urbano a favor de interesses eminentemente privados e em detrimento da regulação vigente sobre expansão urbana. Assim, busca-se ir além de uma análise meramente normativa, a fim de verificar os possíveis resultados da aplicação das normas. Conforme salientado por Gabriel Ignacio Anitua, “a principal pergunta no trabalho empírico sobre o direito já sancionado é : como ele funciona?" (ANITUA, 2006, p. 309-310). O intuito, portanto, é compreender o desenvolvimento real das formulações jurídicas, diferente do dever ser ou ideal, que costuma ser matéria da dogmática jurídica. (ANITUA, 2006, p. 312).

\subsection{Esclarecimentos metodológicos iniciais}

Até que se chegue propriamente na demarcação do perímetro urbano de Ribeirão Preto e toda a discussão sobre sua captura econômica, é essencial entender as forças nem sempre tão óbvias que agem pelos vários estratos políticos do planejamento urbano das cidades, tanto em escala regional como global. O intuito é tentar criar um cenário minimamente claro sobre os diversos fatores e atores que dirigem o destino da cidade para, 
então, possibilitar uma leitura crítica sobre a legislação vigente a partir do todo - "com todas as cartas na mesa".

Essa primeira tarefa se justifica porque é comum pensar o planejamento da expansão urbana como uma tarefa eminentemente técnica, como se a organização do espaço fosse (apenas) fruto de uma equação racional-quantitativa da administração pública, livre de questões políticas e ideologias - inclusive, erroneamente se atribui à legislação urbanística a mesma carapaça de neutralidade. Talvez isso se dê pela difícil tarefa de enxergar uma trajetória político-filosófica completamente abstrata por detrás de um espaço urbano materializado (o objeto concreto da cidade parece algo natural, como se sempre estivesse ali, a despeito de qualquer intervenção ou pensamento humanos). É justamente por isso que Milton Santos (2000, p.9), adverte que "tudo é ideológico. Estamos dentro de um mar de ideologias. Tudo é produzido a partir de uma ideologia, mas as coisas não aparecem como tal. Somos cercados por coisas que são ideologia, mas que nos dizem ser realidade”. O mesmo já havia sido argumentado por Henri Lefebvre (1976, apud SOJA,1993, p. 102) no sentido de que:

(o espaço) não é um objeto científico afastado da ideologia e da política; sempre foi político e estratégico. Se o espaço tem uma aparência de neutralidade e indiferença em relação a seus conteúdos e, desse modo, parece ser "puramente" formal, a epítome da abstração racional é precisamente por ter sido ocupado e usado, e por já ter sido o foco de processos passados cujos vestígios nem sempre são evidentes na paisagem. $\mathrm{O}$ espaço foi formado e moldado a partir de elementos históricos e naturais, mas esse foi um processo político. O espaço é político e ideológico. É um produto literalmente repleto de ideologias

Sendo assim, nesse primeiro momento é necessário recorrer a outras ciências, como a sociologia, a geografia e o urbanismo, para ilustrar o que se enxerga do cenário urbano em sua totalidade histórica, tentando identificar o atual papel da legislação urbanística no complexo processo de expansão urbana (na cidade de Ribeirão Preto). Parte-se, portanto, de uma análise materialista sobre a formação do espaço urbano, pois busca-se um módulo ótico constatativo e não normativo. Essa pesquisa pretende entender as disposições do presente como resultantes de um processo histórico que influencia e é influenciado pelas interações sociais sob as regras do sistema econômico vigente.

Baseando-se na classificação de Fabiana Oliveira (2012) é possível concluir que o tipo de pesquisa a ser desenvolvido nessa proposta se encaixa no perfil de pesquisa não doutrinária, ou empírica. De acordo com a autora, esse procedimento tem como objetivo descrever, explicar e/ou criticar o direito e os fenômenos jurídicos tal qual eles se manifestam na realidade. Portanto, a pesquisa empírica permite verificar como o aspecto 
material do Direito se realiza concretamente e como fatos, atos e atividades concretizam o Direito na vida em sociedade. Em outras palavras, o empirismo jurídico foca em como o Direito e as instituições jurídicas operam em um contexto social, econômico e político mais amplo. É importante ressalvar que os dois tipos de pesquisa (doutrinária e empírica) muitas vezes se misturam em abordagens para responder a problemas propostos, sendo que nas pesquisas empíricas necessariamente há o "recurso a aspectos da pesquisa teórica ou doutrinária para o estabelecimento de parâmetros, e para a definição e a operacionalização de conceitos" (ARTHURS, 1983). Admite-se, portanto, que os dados coletados empiricamente serão contextualizados pela doutrina disponível sobre o tema, visando assim a criação de uma visão holística sobre o universo particular da cidade de Ribeirão Preto sobre o mundo em sua totalidade.

Em se tratando de uma abordagem sociológica do direito, vale ressaltar que o objeto das Ciências Sociais é essencialmente qualitativo. (MINAYO, 1994). O Direito tem uma carga histórica, cultural, política e ideológica que não comporta as limitações de uma fórmula numérica ou num dado estatístico. Além da discussão realizada nos tópicos anteriores, sobre a questão da neutralidade, Minayo (1994, p. 37) esclarece:

Nenhuma pesquisa é neutra seja ela qualitativa ou quantitativa. Pelo contrário, qualquer estudo da realidade, por mais objetivo que possa parecer, por mais "ingênuo" ou "simples" nas pretensões, tem a norteá-lo um arcabouço teórico que informa a escolha do objeto, todos os passos e resultados teóricos e práticos.

Por fim, é importante esclarecer que além de ampla consulta à bibliografia sobre o tema, a pesquisa empírica será realizada através do levantamento de dados documentais e estatísticos junto à Secretaria de Planejamento e Gestão Pública - SEPLAN do município de Ribeirão Preto; ao Conselho Municipal de Urbanismo (COMUR); ao CATI - Escritório de Desenvolvimento Rural de Ribeirão Preto; à Câmara Municipal de Ribeirão Preto, ao Ministério Público do Estado de São Paulo e ao Fórum Estadual de Ribeirão Preto, onde serão consultados documentos referentes à política de expansão urbana bem como sobre a conformação política envolvendo o estabelecimento do Plano Diretor de Ribeirão Preto.

A análise desses dados será feita da seguinte forma:

Parte geral: elaboração de tabelas dispondo de leis federais, estaduais e municipais (Ribeirão Preto) que mencionem ou alterem o perímetro urbano, organizando-as em ordem cronológica. Logo em seguida os textos serão analisados à luz dos referenciais teóricos elencados, refletindo sobre as alterações matérias que realizam ou não na realidade 
destacada, criando um panorama histórico de sua função enquanto agente produtor da realidade urbana.

Análise de caso: os dados coletados sobre a região periurbana da Cidade de Ribeirão Preto serão sobrepostos sobre o mapa da cidade de maneira que seja possível visualizar criticamente a configuração espacial da cidade de acordo com os padrões de renda, recebimento de investimentos públicos, raça, escolaridade. Verificando, assim, eventuais influências econômicas sobre mercado imobiliário sobre organização territorial da cidade em seus momentos de expansão.

\subsection{Conceitos teórico-metodológicos}

Ainda que nunca tenha explicitamente definido o conceito de materialismo histórico dialético, a obra de Marx nos permite extrair algumas noções metodológicas nesse sentido. Avesso ao idealismo, o filósofo alemão examina as condições materiais da existência humana como fundamento da pesquisa social. A concepção de história consiste, pois, em expor o processo real de produção, partindo dele para a produção material da vida imediata (é enxergar a sociedade civil em suas diferentes fases e tê-las como fundamento de toda a história, expondo sua ação enquanto Estado e explicando a base de todos os seus diversos produtos teóricos e formas de consciência, da religião, da filosofia, da moral e etc.)

Essa concepção, diferente do idealismo hegeliano ${ }^{2}$, não busca uma categoria em cada período, senão a que se mantém sobre o terreno histórico real - não explica a prática partindo da ideia, mas explica as formações ideológicas sobre a base da prática material, por qual chega, consequentemente, a conclusão de que todas as formas e todos os produtos da consciência não podem ser destruídos por obra da crítica intelectual (mediante a dissolução na "autoconsciência" ou a transformação em "fantasmas", etc). Só podem dissolver-se pela derrocada prática das relações sociais reais. É o que se denota por Marx e Engels em Fuerbach (2012, p. 70):

\footnotetext{
${ }^{2}$ A mencionada aproximação entre Hegel e Marx é procurada na dialética idealismo-materialismo. Hegel é marcadamente idealista e Marx, por sua vez, materialista. De maneira superficial, o primeiro considera que o homem se desenvolve por si mesmo, ou seja, a consciência humana independe da natureza, mas sim das ideias. Desta forma o idealismo hegeliano não levava em consideração as origens materiais para o desenvolvimento da consciência humana, diferente do materialismo que acredita que o homem se desenvolve na medida em que interage com a natureza e modifica os meios de produção material.(SPIRKINE; YAKHOT,1975) SPIRKINE, A. YAKHOT, O. Princípios do Materialismo Dialético. S. São Paulo: Estampa, $1975 \mathrm{a}$
} 
Esta concepção revela que a historia não termina dissolvendo-se na autoconsciência, como o "espíritu do espíritu", mas sim que em cada uma de suas fases se encontra um resultado material, uma soma de forças produtivas, uma relação historicamente criada dos homens com a natureza e de uns com os outros, que cada geração transfere à que se segue, uma massa de forças produtivas, capitais e circunstâncias, que, ainda que por um lado sejam modificados pela nova geração, de outro ditam a esta as suas próprias condições de vida e a imprimem um determinado desenvolvimento, um caráter especial de que, portanto, as circunstâncias fazem os homens na mesma medida em que os homens criam as circunstâncias (tradução livre)

Leandro Konder em "Dialética como método" (2008, p.54), elucida que para Marx, a espécie humana se percebe através de um corpo, uma dimensão natural concreta. Por conta disso, a natureza do ser se modifica materialmente, na interação física com o mundo: "ao atuar sobre a natureza exterior, o homem modifica, ao mesmo tempo, sua própria natureza". Ainda, o método dialético estimula a revisão do passado à luz do que está acontecendo no presente; ele questiona o presente em nome do futuro, o que está sendo em nome do que "ainda não é" (2008, p. 83) - criando uma consciência de que nada está posto definitivamente, logo, tudo pode ser alterado.

O perfil transmutante da natureza humana, portanto, não se coaduna com a proposta essencialmente espiritual (como em Hegel) e sim com a transformação material, "que abrange a modificação não só das formas de trabalho e organização prática de vida, mas também dos próprios órgãos dos sentidos: o olho humano passou a ver coisas que não enxergava antes, o ouvido humano foi educado pela música para ouvir coisas que não escutava antes etc".

Justamente por conta desse entendimento, Konder (2008, p.35) argumenta que um processo de transformação social só pode se dar após a fiel percepção da realidade, o que só se conseguiria emoldurando-a num quadro de totalidade aberta de fatos e eventos (ou seja: através de esquemas que não pretendem "reduzir" a infinita riqueza da realidade ao conhecimento.)

Segundo o autor, na dialética marxista o conhecimento é totalizante e a atividade humana, em geral, é um processo de totalização que nunca alcança uma etapa definitiva e acabada. "Qualquer objeto que o homem possa perceber ou criar é parte de um todo. Em cada ação empreendida, o ser humano se defronta, inevitavelmente, com problemas interligados"(KONDER, 2008, p. 35). Com base nisso, diante de problemas cotidianos (como os problemas urbanos posteriormente elencados), o ser humano precisa ter uma certa visão de conjunto deles: é a partir da visão do conjunto que podemos avaliar a dimensão de cada elemento do quadro. Pretende-se, com a utilização da visão materialista histórico 
dialética, evitar atribuições exageradas de valor a uma verdade limitada (transformando-a em mentira), facilitando a compreensão de uma verdade mais geral (é justamente essa estrutura significativa - que a visão de conjunto proporciona - que é chamada de totalidade)

Posto isso, é importante elencar que há totalidades mais abrangentes e totalidades menos abrangentes, a depender do nível de generalização do pensamento dos objetivos concretos dos homens em cada situação dada. Konder (2008, p. 37) esclarece que, se a pesquisa está empenhada em analisar questões políticas que estão sendo vividas por um determinado país, o nível de totalização necessário é o da visão de conjunto da sociedade desse lugar, da sua economia, da sua história, das suas contradições atuais. Entretanto, se a intenção é aprofundar a análise e entender a situação do Brasil no quadro mundial, é necessário um nível de totalização mais abrangente: “(...) vou precisar de uma visão de conjunto do capitalismo, da sua gênese, da sua evolução, dos seus impasses no mundo de hoje".

Vale lembrar que a totalidade é apenas um momento de um processo de totalização (que nunca alcança uma etapa definitiva e acabada). Afinal,

(...) a dialética - maneira de pensar elaborada em função da necessidade de
reconhecermos a constante emergência do novo na realidade humana - negar-
se-ia a si mesma, caso cristalizasse ou coagulasse suas sínteses, recusando-se a
revê-las, mesmo em face de situações modificadas. A modificação do todo só se
realiza, de fato, após um acúmulo de mudanças nas partes que o compõem.
Processam-se alterações setoriais, quantitativas, até que se alcança um ponto
crítico que assinala a transformação qualitativa da totalidade. E a lei dialética da
transformação da quantidade em qualidade (idem, p. 38)

Portanto, para que o conhecimento continue o constante ofício de depurador da realidade (para que se possa ir além das aparências e penetrar na essência dos fenômenos) são necessárias operações de síntese e de análise que esclareçam não só a dimensão imediata como também, e sobretudo, a dimensão mediata delas. Konder (idem p. 44-45) ensina que em todos os objetos com que se lida diariamente existe uma dimensão imediata (percebidos imediatamente) e existe uma dimensão mediata, que vai se descobrindo, construindo ou reconstruindo aos poucos.

Com base nisso, a presente pesquisa pretende construir gradualmente a totalidade Ribeirão-pretana a partir de produtos materiais locais de sua história bem como identificando seus processos urbanos no contexto internacional do capitalismo financeiro, com base nas teorias de Henri Lefebvre (direito à cidade), David Harvey (Produção Capitalista do espaço) e Raquel Rolnik (Financeirização do território urbano em "Guerra dos Lugares"). 


\title{
1.3 A produção capitalista do espaço urbano
}

\subsubsection{A origem do urbano com base em Henri Lefebvre}

A partir de uma análise materialista, Henri Lefebvre, em O direito à Cidade (2001), descreve a origem da configuração sociopolítica das cidades industriais oitocentistas, permitindo entender um pouco os processos que culminaram nas atuais conformações urbanas (primeiro, o autor diferencia os burgos medievais para então evidenciar as transformações sofridas durante a industrialização).

Para o autor, as cidades medievais são centros de vida social e política onde se acumulam não apenas as riquezas como também os conhecimentos, as técnicas e as obras (obras de arte, monumentos):

\begin{abstract}
"A própria cidade é um obra, e esta característica contrasta com a orientação irreversível na direção do dinheiro, na direção do comercio, na direção das trocas, na direção dos produtos. Com efeito, a obra é valor de uso e o produto é valor de troca. O uso principal da cidade, isto é, das ruas e das praças, dos edifícios e dos monumentos, é a Festa (que consome improdutivamente, sem nenhuma outra vantagem além do prazer do prestígio, enormes riquezas em objetos e em dinheiro). (LEFEBVRE, 2001,p. 12)
\end{abstract}

Com a industrialização, as terras saem da esfera dos feudais e passam para as mãos dos capitalistas urbanos enriquecidos "pelo comércio, pelo banco, pela usura". Além disso, a cidade, o campo e as novas instituições que passam a regulamentar as relações tenderam a constituir uma nova divisão de trabalho (tecnicamente, socialmente e politicamente), tudo isso através de uma rede de centro urbanos ligados por estradas, hidrovias, relações comerciais e bancárias (LEFEBVRE, p.13)

$\mathrm{O}$ autor identifica o surgimento da cidade moderna através de um processo com dois aspectos: industrialização e urbanização, crescimento e desenvolvimento, produção econômica e vida social. Os dois "aspectos" deste processo, inseparáveis, tem uma unidade e, ao mesmo tempo, um conflito (um choque violento entre a realidade urbana e a realidade industrial vez que não apenas empresas entram em cena, mas estabelecimentos diversos, centros bancários e financeiros, técnicos e políticos). Segundo o autor, muito embora já estejamos em fases mais avançadas do capitalismo esse processo dialético e conflituoso do sistema com o espaço urbano está longe de ser compreendido justamente por estar sempre se modificando. Por exemplo, cita a contradição entre necessidade de mão de obra versus inchaço da cidade. (A população depende de polos de crescimento industrial para 
conseguir emprego e acaba induzindo o que Lefebvre chama de "implosão-explosão" da cidade - p. 18).

Muito embora Lefebvre enxergue certa espontaneidade no desenvolvimento desse tipo de cidade também deixa claro que, na maior parte das vezes, ele é dirigido pelo interesse de setores dominantes da sociedade. As classes ou frações de classes dirigentes, que possuem o capital (os meios de produção), geram não apenas o emprego econômico do capital e os investimentos produtivos, como também a sociedade inteira, com o emprego de uma parte das riquezas produzidas na "cultura", na arte, no conhecimento, na ideologia. Toda a noção de urbanidade é produzida segundo os interesses daqueles que controlam a cidade, desde o formato físico da cidade até as mais íntimas relações de cidadania - tudo isso amparado e viabilizado pelo poder do Estado, através de imposições e o uso da força. Para ilustrar esse poder do planejamento urbano dirigido na vida cotidiana, o autor cita as reformas feitas em Paris pelo barão Haussmann, que alargou as ruas permitindo maior atuação dos aparatos policiais bonapartistas em repressões políticas a manifestantes contrários ao regime, bem como criou boulevards em zonas mais pobres empurrando a população para as periferias da cidade (LEFEBVRE,2001, p. 23):

\footnotetext{
O barão Haussmann, homem desse Estado bonapartista que se erige sobre a sociedade a fim de trata-la cinicamente como o despojo (e não apenas arena) das lutas pelo poder, substitui as ruas tortuosas mas vivas por longas avenidas, os bairros sórdidos mas animados por bairros aburguesados. Se ele abre boulevards, se arranja espaços vazios, não é pela beleza das perspectivas. É para "pentear Paris com as metralhadoras" (Benjamin Péret). O célebre barão não esconde isso. Mais tarde, serão gratos a Haussmann por ter aberto paris à circulação. Essa não era a finalidade, o objetivo do "urbanismo" haussmaniano. Os vazios tem um sentido: proclamam alto e forte a glória do poder do Estado que os arranja, a violência que neles pode se desenrolar. Mais tarde efetuam-se transferências para outras finalidades que justificam de uma outra maneira os entalhes na vida urbana.
}

Para o autor, as intervenções violentas e "suburbanizantes" do Estado Francês, em favorecimento dos estratos mais abastados, principia um processo que descentraliza a Cidade e a afasta daqueles que a constroem - a classe trabalhadora (LEFEBVRE,2001, p.25). Em outras palavras, esse distanciamento faz com que os operários, que empregam sua mão de obra na construção da cidade, percam a consciência de sua capacidade criadora e, portanto, são vulnerados por esse processo alienante.

Isso inaugura um processo recorrente na urbanização capitalista a que chamou de “urbanização desurbanizante e desurbanizada". Isto é, muito embora os "suburbanos" não deixem de ser urbanos podem perder a consciência de sua condição enquanto cidadão da cidade se desvinculando física e politicamente da vida nela. Assim como são privados de 
usufruir dos avanços e benefícios que produzem na e para a própria cidade, afinal, são realocados para espaços cada vez mais longínquos e sem infraestrutura adequada.

Diante dessas colocações, Lefebvre resume em três períodos o processo histórico que culminou no atual formato de cidade capitalista (LEFEBVRE,2001, p. 28):

\begin{abstract}
Primeiro período - A indústria e o processo de industrialização assaltam e saqueiam a realidade urbana preexistente, até destruí-la pela prática e pela ideologia, até extirpá-la da realidade e da consciência. Conduzida segundo uma estratégia de classe, a industrialização se comporta como um poder negativo da realidade urbana: o social urbano é negado pelo econômico industrial.

Segundo período - (em parte justaposto ao primeiro) - A urbanização se amplia. A sociedade urbana se generaliza. A realidade urbana, na e por sua própria destruição, faz-se reconhecer como realidade sócio-econômica. Descobre-se que a sociedade inteira corre o risco de se decompor se lhe faltarem a cidade e a centralidade: desapareceu um dispositivo essencial para a organização planificada da produção e do consumo.

Terceiro período - Reencontra-se ou reinventa-se (não sem sofrer com sua destruição na prática e no pensamento) a realidade urbana. Tenta-se restituir a centralidade. Teria desaparecido a estratégia de classe? Não se sabe ao certo. Ela se modificou. As centralidades antigas, a decomposição dos centros são por ela substituídas pelo centro de decisão. É assim que nasce ou renasce a reflexão urbanística. Esta sucede a um urbanismo sem reflexão.
\end{abstract}

O resultado recente desse processo seria o "urbanismo dos promotores de venda", em que o empresariado concebe e realiza, sem nada ocultar, uma organização espacial para o mercado, visando o lucro. O fato novo, segundo o autor, é que não se vende mais uma moradia ou um imóvel, mas sim um tipo de urbanismo. Com ou sem essa ideologia, o urbanismo torna-se valor de troca e o projeto desses promotores de venda se apresenta como ocasião e local privilegiados: "lugar de felicidade numa vida cotidiana miraculosa e maravilhosamente transformada”. (LEFEBVRE,2001, p. 32)

Como será analisado posteriormente, há muito disso em comum com o estilo de vida propagandeado pelos condomínios fechados a partir da década de 80 no Brasil, com destaque para os da região sul de Ribeirão Preto. Consequentemente, esse fazer urbano comercial com toda sua complexidade política e territorial demandou a formatação de uma ampla frente de estratégias urbanísticas, envolvendo desde a regulação do planejamento até as estruturas político-partidárias, para assim assegurar os ganhos dos empresários (e dar continuidade aos mencionados processos de acumulação). O impacto dessa visão de urbanismo não só afeta a formatação de leis organizadoras da cidade como restringe o acesso ao direito à cidade por parte da população, determinando nos mínimos detalhes os papéis dos cidadãos de acordo com sua classe e localidade.

Extrai-se da obra de Lefebvre que a determinação capitalista para a organização espacial descende do modelo industrial num primeiro momento, e hoje, com a transmutação para o modelo de mercado financeiro globalizado, essa relação se torna ainda mais 
complexa e entrelaçada. Esboça-se uma estratégia global que modula as cidades e as formata em sociedades de consumo dirigido onde são construídos não apenas centros comerciais como também centros de consumo privilegiados: a cidade renovada, o condomínio de luxo, o boulevard gastronômico e etc. que visam, entre outros objetivos, à criação de nichos de atratividade para investimentos altamente lucrativos (hoje muito mais fluidos com a financeirização dos recursos). O problema não estaria na criação da zona de atratividade de investimentos em si, mas a que custo ela se perfaz em relação aos direitos da coletividade e ao acesso aos seus benefícios.

O que permeia essa estratégia (e a torna viável) é a imposição de uma ideologia da felicidade através do consumo, condicionando a existência dessa alegria à criação infinita de novos espaços por onde ela se realiza. Denota-se que o setor imobiliário inflama uma necessidade nem sempre espontânea por "cidades diferenciadas" (que possibilitam vidas “invejáveis"). Como se a própria população demandasse esse tipo de ocupação segregada do território, justificando e mistificando os demais interesses que permeiam a produção capitalista do solo urbano, bem como mascarando os eventuais abusos de direito que nela possam acontecer - eis o urbanismo adaptado à sua nova missão.

O papel do Estado é bastante controverso nessa empreitada, como será pormenorizado adiante. Muito embora existam direitos e garantias que condicionem a função social da propriedade bem como princípios coletivistas da administração pública, não são raros os momentos em que o Estado opera a contragosto desses dispositivos em função de privilégios econômicos de determinados setores. Há, por exemplo, evidente conivência do poder público a esses privilégios quando instituições públicas que concentram os meios do poder (informação, formação, organização, operação) são preferencialmente colocadas em bairros já em vantagem em relação aos demais, reforçando sua valorização. Ou então são realocados justamente para que eles próprios valorizem a região a ser comercializada, horando os interesses de loteadores e investidores. (em Ribeirão Preto, por exemplo, há uma agência da polícia federal dentro do Shopping Iguatemi, na rica zona sul, e os parques públicos mais estruturados da cidade estão rodeados de prédios alto padrão. Mais detalhes a posteriori). É inegável, também, a atuação do Estado como responsável pela repressão (coações, inclusive a violência) e persuasão (ideologia, publicidade) contra quaisquer tipos de manifestações contrarias ao establishment aqui evidenciado (vide o caso dos rolezinhos e das remoções violentas de comunidades de favela). 
Lefebvre argumenta que ao redor e a partir desses centros de valorização a cidade é estratificada, em ordem dispersa, segundo normas e coações previstas, até que se chegue nas periferias, a região da urbanização desurbanizada. "Todas as condições se reúnem assim para que exista uma dominação perfeita, para uma exploração apurada das pessoas, ao mesmo tempo como produtores, como consumidores de produtos, como consumidores de espaço". (LEFEBVRE,2001, p. 33) Nesse sentido, a defesa do direito à cidade não pode ser concebido como um simples reivindicação do "direito de visita" ou de retorno às cidades tradicionais. "Só pode ser formulado como direito à vida urbana, transformada, renovada. (...)" (LEFEBVRE,2001, p. 105). "O urbano", deve se lugar de encontro, ter prioridade do valor de uso, "inscrição no espaço de um tempo promovido à posição de supremo bem entre os bens, encontre sua base morfológica, sua realização práticosensível."

\subsubsection{O processo de acumulação capitalista e a necessidade de expansão territorial (com base em David Harvey)}

Analisando escritos fragmentários de Marx, David Harvey argumenta que o filósofo reconhecia o perfil territorial da acumulação de capital (acumulação num contexto geográfico), criando tipos específicos de estruturas espaciais. Vale ressaltar que, o autor (2005, p. 73) define o capital não como uma coisa ou conjunto de instituições, mas como um processo de circulação entre produção e realização. Esse processo precisa se expandir, acumular, reformar constantemente o processo de trabalho e os relacionamentos sociais na produção, assim como precisa mudar constantemente as dimensões e as formas de circulação.

Com base nisso, é possível ligar o processo geral de crescimento econômico com o entendimento explícito de uma estrutura emergente de relações territoriais. Para tanto, Harvey (2005,p.43) também busca na teoria marxista da acumulação os fundamentos para o entendimento da estrutura espacial:

Para Marx, a acumulação de capital é o "motor cuja potência aumenta no modo
de produção capitalista". Sendo assim, o capitalismo é muito dinâmico e
inevitavelmente expansível, desencadeando uma força permanentemente
revolucionária alterando a forma do mundo a todo momento. (Harvey, 2005,
p.43). com frequência, transparecem na forma de crises, vulnerando todo o funcionamento do sistema. A constante ameaça desse risco produz tensões no processo de acumulação, que passa a depender das seguintes circunstâncias para ter um mínimo de sustentabilidade: 
a) A disponibilidade de um exército de reserva industrial (excedente de mão de obra) que possibilite a expansão da produção. Portanto, são necessários mecanismo de aumento da oferta de força de trabalho (seja por estímulo ao crescimento demográfico, às correntes migratórias, alteração de leis trabalhistas e etc.)

b) A disponibilidade de meios de produção no mercado (ou oportunidade de obtenção) - máquinas, infraestrutura, matéria prima que possibilitem a expansão da produção conforme o capital seja reinvestido.

c) A disponibilidade de mercado para absorver as quantidades crescentes de mercadorias produzidas

A dificuldade em prover cada um desses quesitos com a fluidez necessária pode desencadear uma crise de crescimento do mercado e, consequentemente, afetar toda a economia. Entretanto, Marx concluiu que o capitalismo tende, ativamente, a produzir algumas das barreiras para seu próprio desenvolvimento pelo fato de que as crises são endêmicas ao processo capitalista de acumulação, afinal:

"a produção não é apenas imediatamente consumo e o consumo não é apenas imediatamente produção, a produção não é apenas meio para o consumo e o consumo não é apenas o objetivo da produção [...] mas também, tanto a produção quanto o consumo [...] criam o outro, completando-se e criando-se enquanto o outro (Marx, 1973, p. 93 apud HARVEY, 2005).

Isto é, as crises muitas vezes são produzidas para que, na recuperação, o sistema continue caminhando na sua lógica infinita e expansiva: a produção e o consumo se integram de modo dialético na produção como totalidade Periodicamente, essa mesma regra econômica geral produz uma superabundância de capital bem como suscita uma superpopulação relativa, sendo, portanto, um fenômeno que suplementa esse último, embora se situem em pólos opostos: capital inaproveitado em um pólo e população trabalhadora desempregada no outro. (HARVEY, 2005, p.45). Sendo assim, a conquista de novos espaços acaba sendo a saída viável para descomprimir tanto o capital acumulado em busca de novos horizontes de investimentos como para a pressão da alta população em busca de empregos, a serem gerados pelos investimentos em capital produtivo e etc. Harvey elucida resumidamente essa ideia no seguinte trecho (2005, p. 47):

(...) [a crise] desencadeia um processo de racionalização forçada. Tudo o que precisará acontecer, se for para sustentar o sistema capitalista, será a criação de condições apropriadas para a renovação da acumulação. Em geral, as crises periódicas devem ter o efeito de expandir a capacidade produtiva e de renovar as condições de acumulação adicional. Podemos conceber cada crise como uma mudança do processo de acumulação para um nível novo e superior. 
É importante ressaltar que, para o autor, as correções forçadas e periódicas relativas ao curso da acumulação do capital também podem, facilmente, escapar do controle e inflar movimentos revolucionários e o caos, que, tipicamente, produzem "o terreno de reprodução para o fascismo". Denota-se aqui o frágil equilíbrio entre a saúde econômica e a viabilidade política de Estados mais inclusivos e democráticos, daí vislumbra-se uma relação teórica para as interferências econômicas no fazer urbano das cidades bem como no perfil (mais ou menos inclusivo) dessa atividade .

Harvey (2005, p. 48) também sugere que a recuperação dessas crises cíclicas podem se dar pela a) inserção do capital em novas esferas de atividade ainda não organizadas pelo capitalismo (por exemplo transformar agricultura de subsistência em agrobusiness; b) pela criação de novos hábitos de consumo, estimulando novas necessidades e provendo o mercado com novos produtos; c) pela facilitação e o estímulo para o crescimento populacional de modo organizado visando a continuar as dinâmicas de acumulação a longo prazo; e d) pela expansão geográfica para outras regiões, permitindo o investimento do capital excedente em outras localidades (rumo à criação do "mercado mundial"3)

Aqui, Harvey diferencia os três primeiros itens como matérias de intensificação da atividade social, dos mercados, das pessoas numa específica estrutura espacial. O último item, complementando a visão de Marx e Lefebvre, suscita a questão da organização espacial e da expansão geográfica como produto necessário para o processo de acumulação. (2005 p. 52). Uma vez classificada e consolidada como modalidade diferenciada no processo de acumulação, a expansão geográfica pode ser analisada com maior especificidade e, assim, aproximar-se do tema da presente pesquisa. Um dos elementos mais marcantes desse movimento é a utilização de tecnologias financeiras que permitem a transferência fluida do capital apesar das inconveniências geográficas. Marx já vislumbrava essa possibilidade nos Grundrisse :

“(...) a circulação se afigura como processo essencial do capital. O processo de produção não recomeça antes da transformação da mercadoria em dinheiro. A continuidade constante desse processo, a transição desimpedida e fluida do valor de um forma em outra, ou de uma fase do processo para a seguinte, afigura-se como condição essencial para a produção como base no capital, em um grau muito maior do que em todas as formas mais antigas de produção. (MARX, 1973, p. 535)

Harvey cita o sistema financeiro como ferramenta que possibilita a desmaterialização do valor de determinado bem de capital e assim permitir que ele gire

\footnotetext{
${ }^{3}$ Conceito de mercado mundial em marx
} 
livremente no mercado, aumentando o dinamismo esperado pelos investidores. Para o autor, esse sistema de crédito possibilita a expansão geográfica do mercado por meio do estabelecimento da continuidade onde antes não existia continuidade alguma. Isto é, essa tecnologia financeira suprime a barreira territorial pois consegue encurtar o tempo das transações, gerando fluidez. (viabilidade fática da negociação - anulação do espaço pelo tempo) (2005, p 52)

Vale ressaltar que esse processo não está livre das contradições ${ }^{4}$ típicas do desenvolvimento capitalista, o que desencadeia uma série de tensões na produção do solo urbano. Se por um lado a expansão do capital para novos territórios depende de mecanismos financeiros 'desmaterializantes', como a fluidez do sistema de crédito, por outro lado a ocupação desses novos espaços com objetos construídos (capital novamente materializado em forma de prédios, condomínios e etc) cria nova barreira ao mercado vez que sua existência é antitética ao objetivo de facilitar a circulação de bens e capitais.

Segundo Harvey, essa contradição reside no fato de que o capital passa a ser representado na forma de uma paisagem física, criada à sua própria imagem, como valor de uso, acentuando a acumulação progressiva do mesmo: “A paisagem geográfica, abrangida pelo capital fixo e imobilizado, é tanto uma glória coroada do desenvolvimento do capital passado, como uma prisão inibidora do progresso adicional da acumulação (...)" afinal, são impossíveis de serem movidos sem serem destruídos (HARVEY, 2005, p. 53). Sendo assim, define-se o desenvolvimento espacial do capitalismo como uma eterna "corda bamba" entre preservar o valor dos investimentos passados de capital na construção do ambiente e destruir esses investimentos para abrir espaço novo para a acumulação. Como consequência dessa contradição pendular, é possível testemunhar uma disputa contínua de construção e destruição de espaços conforme perdura sua utilidade (são consumidos). Interessante notar que esse é um dos fatores determinantes para a organização de diferentes estratos de valor entre bairros, conferindo-lhes maior ou menor atratividade, favorecendo a atuação do mercado (e fazendo girar o incessante motor da especulação imobiliária). $\mathrm{O}$ autor ainda elucida que as crises cíclicas do investimento de capital fixo, muitas vezes compreendidas como ondas longas do desenvolvimento econômico, "são, portanto, normalmente expressas como reformas periódicas do ambiente geográfico, para adaptá-lo às necessidades da acumulação adicional.” (HARVEY, 2005, p. 54) 
Flavio Villaça (2001, p. 153) descreve esse fenômeno no livro Espaço Intraurbano no Brasil quando analisa as mudanças de valor nos bairros classificados como de alta renda sempre na mesma direção, sempre mantendo alguma comunicação com as regiões centrais. São bairros que 'andam' em determinado sentido dentro do tecido urbano conforme se criam novas centralidades de valorização, por exemplo o Rio de Janeiro cuja elite primeiro se instala na Glória, depois vai para o Flamengo-Catete, em seguida Botafogo, Copacabana, Ipanema, Leblon, São Conrado e, agora, tem a Barra da Tijuca como ponto de valorização.

O mesmo se observa em São Paulo, que partiu dos Campos Elíseos, para Higienópolis e Vila Buarque, depois Avenida Paulista, Jardim América e Alto de Pinheiros, Morumbi, Jardim Leonor, Granja Viana, Alphaville, e etc. Por fim, também é possível vislumbrar semelhança no caso de Ribeirão Preto, cuja centralidade sempre avança em direção à zona sul (Antes os casarões mais abastados do período cafeeiro circundavam o quadrilátero central, em seguida para o Alto da Boa Vista, Jardim América, Jardim Canadá, Região da Fiúsa e agora para a região do Shopping Iguatemi e de Bonfim Paulista). A partir de um ponto de contato com o centro, essas classes se expandiram num setor de círculo por bairros próximos ao centro - mas não encostados ou dentro dele - como Higienopolis e Pacaembu em São Paulo. Mantendo (quando não rompidas por completo) a relação com essa localidade e mantendo a ponte entre novas regiões de valorização e velho capital investido.

De maneira geral, infere-se que enquanto a derrubada das barreiras espaciais em função da troca talvez crie dependência elas também transformam as coisas necessárias em luxos, beneficiando a economia recém-introduzida no metabolismo da troca. (Harvey, 2005 , p. 67). Portanto, esses autores se apoiam sobre a teoria de que tanto o atraso quanto o subdesenvolvimento podem e devem ser produzidos e perpetuados pela penetração das relações sociais capitalistas nas economias não capitalistas. O que explicaria, por exemplo, o relacionamento genérico existente entre o Terceiro Mundo e os centros metropolitanos da acumulação. Sendo assim, vislumbram a existência de diferentes escalas da relação centro-periferia, tanto em níveis continentais (Norte X Sul) como em níveis locais, como na existência de bairros mais ou menos valorizados.

\subsubsection{A economia política do século XXI: financeirização do solo urbano e rural}

A partir da construção desse panorama geopolítico da acumulação do capital sob expansão territorial, Harvey tenta encaixar o atual papel do Estado nesse jogo complexo. 
Fica evidente, em sua escrita, a preocupação com a índole confusa dessa Instituição no começo do século XXI (HARVEY,2005, capítulo III, p. 77):

"considero que estou assistindo a uma reprise de um filme exaurido da década
de 1930,com sombras da década de 1890 , com objetivos como "justiça social" e
"conservação" sendo gradualmente convertidos em objetivos de eficiência e
racionalidade do mercado, com um toque de muito socialismo para os ricos,
auxílio financeiro para empresas e instituições financeiras pouco sólidas etc."

Obviamente não seria correto afirmar que o Estado apenas recentemente se tornou agente promotor do aparato capitalista de produção. (HARVEY, 2005, p.79) Ele sempre esteve presente muito embora suas formas e modos de funcionamento mudassem conforme o capitalismo amadurecia.

Entretanto, para o autor, esse século vem vivenciando uma fase de retrocessos que compromete a própria estrutura do Estado de Direito em que se funda a "civilização capitalista". Direitos de propriedade comum, obtidos ao longo de anos de longas disputas históricas, vêm sendo passados para domínio privado através de políticas de espoliação não raro impostas contra a vontade da população, colocando em cheque a gestão democrática. É com base nisso que se tem a impressão de que a crise de 2008 não foi somente um colapso do sistema financeiro desregulado como também evidenciou as limitações do próprio modelo institucional vigente frente aos imperativos de um poder econômico capaz de subverter os mais consolidados interesses coletivos. (ROYER, 2013, p. 27).

Essa situação de indefinição institucional pode se tornar um problema vez que quase em todo processo produtivo destinado ao consumo existe, de maneira direta ou indireta, a presença do Estado, o que inclui a própria construção da cidade (retomando o conceito de Lefebvre da cidade-produto) e, portanto, influenciando diretamente na formação das franjas de crescimento. Sendo assim, além da primeira introdução que buscou construir um breve pano de fundo sobre o motor econômico que pauta a expansão urbana, se faz necessário identificar o possível perfil do Estado contemporâneo (no mundo financeirizado) e então analisar sua atuação da demarcação do perímetro urbano.

Na teoria de David Harvey (2005, p.80), da mesma forma que o trabalhador, mediante o trabalho, cria capital como instrumento para sua própria dominação, os seres humanos criam, na forma do Estado, um instrumento para sua própria dominação - em particular, a lei, o poder de tributação e poder de coação - podem ser transformados, pela luta política, em instrumento para dominação.

O uso do Estado como instrumento de dominação de um determinado estrato social cria uma contradição adicional: os setores dominantes tem de exercer seu poder em seu próprio interesse, enquanto afirma que suas ações são para o bem de todos. Marx e 
Engels (apud Harvey, 1970, p. 106) afirmam que essa contradição se resolve pelo emprego de duas estratégias: a) primeiro, a manifestação da vontade Estatal deve parecer independente e autônoma em suas ações. A autoridade atribuída aos funcionários públicos os diferenciam dos demais membros da sociedade garantindo "santidade e inviolabilidade peculiares"; b) segundo, a estratégia para solucionar a contradição deve se basear na conexão entre ideologia e Estado "Especificamente, os interesses de classe são capazes de ser transformados num interesses geral e ilusório, pois a classe dirigente pode, com sucesso, universalizar suas idéias como idéias dominantes " (Harvey,2005, p. 81)

Para Engels (1941, p. 1570), o Estado, imbuído nessa máscara de neutralidade, está à mercê do interesse através de duas maneiras: corrompendo funcionários públicos (vide escândalos de corrupção tanto no Brasil quanto no mundo) e pela aliança entre governo e a elite financeira (vide crise das hipotecas de 2008, bem como as eleições americanas, ambas fortemente influenciadas pelos interesses de Wall Street).

Em relação a esses fatos, o livro $O$ capital no século XXI do economista francês Thomas Piketty (2014) permite estabelecer uma relação mais fundamentada em dados entre a concentração de renda, o rentismo do mercado financeiro e subversão do poder político no começo desse século. Pelo que se extrai, o mundo hoje se aproxima de um nível de concentração de renda similar ao que existia na Belle Époque, antes da primeira grande guerra, período de maior concentração já registrada (PIKETTY,2014, p. 31)

Ao coletar e analisar dados sobre a renda dos países industrializados desde o século XVIII até o início deste século, o economista argumenta cientificamente a veracidade da tendência de acumulação infinita do capital, ensaiada por Marx. Sendo assim, a economia estaria sempre caminhando para níveis de riqueza extremamente concentrados e desiguais, influenciando nas conformações políticas e proposições de leis, obviamente beneficiando uma oligarquia detentora do poder de decisão. Dentre as provas desse argumento, Piketty demonstra que no sistema financeiro atual as maiores fortunas rendem mais do que as pequenas, criando o risco de se elevar a desigualdade ${ }^{5}$ a níveis inéditos - A taxa de crescimento das maiores riquezas supera a taxa média anual (6,8\% a.a., contra 3,3\% a.a - PIKETTY, 2014, p. 424)

\footnotetext{
${ }^{5}$ Desigualdade fundamental do Capitalismo: Há uma desigualdade fundamental no capitalismo tida como $r>g$, em que $r$ é a taxa de remuneração do capital (isto é, o que rende, em média, o capital durante um ano, sob a forma de lucros, dividendos, juros, aluguéis e etc em porcentagem de seu valor), e g representa a taxa de crescimento ( isto é, o crescimento anual da renda e da produção). Essa lógica é o ponto central do livro. (PIKETTY, 2014, p. 33)
} 
De maneira resumida, entende-se que quando a taxa de remuneração do capital excede substancialmente a taxa de crescimento da economia - como ocorreu durante a maior parte do séc. XIX e tende a ocorrer no século XXI - a riqueza herdada aumenta mais rápido do que a renda e a produção. Basta então que herdeiros poupem uma parte limitada da renda de seu capital para que ele cresça mais rápido do que a economia como um todo. Sob essas condições, é quase inevitável que a fortuna herdada supere a riqueza constituída durante uma vida de trabalho e que a concentração do capital atinja níveis muito altos. Isso seria potencialmente incompatível com os valores meritocráticos e os princípios de justiça social que estão na base de nossas sociedades democráticas modernas.

Dentre os princípios fundantes do pensamento democrático ${ }^{6}$ está a crença (e a esperança) de que as desigualdades de uma sociedade sejam fundadas mais no mérito e no trabalho do que na filiação/ renda. Essa crença desempenha papel central na sociedade moderna pois na democracia, a igualdade proclamada pela declaração dos direitos do homem e do cidadão contrasta de maneira singular com a desigualdade real das condições de vida. Sendo assim, é vital fazer com que as desigualdades sociais resultem de princípios racionais e universais (méritos) e não de contingências arbitrárias: "As desigualdades devem ser justas e úteis a todos (as distinções sociais só podem fundamentar-se na utilidade comum - Decl. dos Direitos do Homem e do Cidadão, 1789") - (PIKETTY, 2014 p. 411)

Inclusive, o economista (PIKETTY, 2014 p. 289) infere que o aumento na concentração de renda pode ter contribuído com a fragilização do sistema financeiro que culminou na crise de 2008, derrubando governos pelo mundo todo. Numa análise mais técnica, argumenta-se que a sociedade mais desigual perde poder de compra e força as classes médias e baixas a recorrer aos empréstimos e os créditos fáceis oferecidos pelos bancos, amparados pela desregulação de mercado exigida pelos grandes banqueiros. $\mathrm{O}$ resultado disso é o endividamento generalizado das classes mais basilares da economia e o desmoronamento do sistema financeiro (sendo que os únicos beneficiados nessa trajetória são os banqueiros).

Outra possível evidência dessa subordinação do poder do Estado ao poder dos grandes rentistas é a existência de supersalários e o "extremismo meritocrático". Para Piketty (idem, 325), o atual poder econômico concentrado na mão de poucos "jogadores"

\footnotetext{
${ }^{6} \mathrm{O}$ que é democracia
} 
do mercado financeiro provoca a inviabilidade da governança empresarial, permitindo salários estratosféricos para os altos cargos. Isso acarreta no aumento do poder político dos diretores e CEOs, que tem maior poder de barganha nos financiamentos políticos de campanha bem como na alteração da legislação a favor dos mais ricos (via lobistas). Então perpetua-se um ciclo cada vez mais desigual e mais concentrador do poder, fazendo do Estado e do interesse público reféns de poucos oligarcas do mercado financeiro.

É curioso que o período de avanço da concentração de renda (e poder) apontado por Piketty, coincide com a disseminação do corolário Neoliberal ${ }^{7}$ por todo o mundo (após década de 70), juntamente com a ideia de que o Estado é menos eficiente e deveria intervir menos na economia. Ainda que, de fato, houvesse alguém esgotamento do modelo desenvolvimentista da época, é possível imaginar uma ligação entre o capital mais concentrado na mão de alguns poucos detentores (geralmente em paraísos fiscais), tirando de circulação o dinheiro que seria arrecadado pelo estado via tributação, enfraquecendo a receita dos Estados e tornando-os dependentes do setor privado para executarem suas atividades. Além disso, segundo a urbanista e relatora da ONU Raquel Rolnik (2015, p. 30) , os think thanks do mundo financeiro formularam essa ideia em Wall Street e na City de Londres e a implantaram na Inglaterra no final dos anos 1970 e início dos 1980, no contexto da guerra fria. A mudança no sentido e no papel econômico de vários serviços e bens, dentre eles o da terra (urbana e rural), ganhou impulso com a queda do Muro de Berlim vez que a subsequente hegemonia do livre mercado permitiria acesso a investimentos antes inacessíveis aos grandes players do mundo financeiro.

Isto é, mais do que uma simples estratégia para dar eficiência às funções estatais “onerosas demais", a transferência das atividades tipicamente públicas para o setor privado também possuía interesses eminentemente financeiros e políticos, como a implantação de um sistema global de mercado que permitisse a capilaridade dos investimentos a lugares nunca explorados (dando continuidade ao processo de acumulação) bem como a dominância do sistema capitalista diante do enfraquecimento das potências soviéticas. $\mathrm{O}$ sentimento de "modelo vitorioso" foi tanto que Francis Fukuyama (1992) se consagrou

\footnotetext{
7 “ O Neoliberalismo é em primeiro lugar uma teoria das práticas político-econômicas que propõe que o bemestar humano pode ser melhor promovido liberando-se as liberdades e capacidades empreendedoras individuais no âmbito de uma estrutura institucional caracterizada por sólidos direitos a propriedade privada, livres mercados e livre comércio. O papel do Estado é criar e preservar uma estrutura institucional apropriada a essas práticas; O Estado tem de garantir, por exemplo, a qualidade e a integridade do dinheiro. Deve também estabelecer as estruturas e funções militares, de defesa, de política e legais requeridas para garantir direitos de propriedade individuais e assegurar, se necessário pela força, o funcionamento apropriado dos mercados. (...) O Estado não deve avernturar-se para além dessas tarefas. (HARVEY, 2008, p. 6)
} 
como pensador ao defender que o modelo de democracia liberal norte-americano se espalharia pelo mundo todo representando o "fim da história", vez que seria o último patamar da evolução civilizatória.

O modelo neoliberal não só foi adotado por muitos governos como imposto como condição para a concessão de empréstimos internacionais por instituições financeiras multilaterais, como o Banco Mundial e o Fundo Monetário Internacional (FMI), o novo paradigma se baseia principalmente na implementação de políticas que criam mercados financeiros mais fortes e maiores, incluindo consumidores de média e baixa rendas, que até então estiveram excluídos.

É bem verdade que depois de sucessivas crises econômicas, como os choques do petróleo, muitos Estados tiveram seus recursos afetados e foram forçados a cortar orçamento de políticas públicas welfaristas. Entretanto, sob a luz das demonstrações de Piketty é possível ir além e enxergar essas crises como possíveis resultados do pico de concentração de renda e esgotamento do período de recuperação do período entre guerras (PIKETTY, 2014, p. 20). Luciana Royer (2013, p. 14) destaca que a partir dos anos 80 instaura-se uma nova fase de financeirização do sistema mundial, em meio à crise fiscal e a insuficiência dos fundos administrados pelos Estados, que esvaziaram a sustentação Estatal das políticas de bem-estar (Deslocou-se para o mercado o atendimento das necessidades básicas da classe trabalhadora). Para a autora, "o orçamento público e os fundos financeiros do Estado deixaram de ser responsáveis pela universalização das políticas públicas, limitando-se ao atendimento de demandas focalizadas e ao fomento de economias de mercado". Em alguns casos, inclusive, o orçamento fiscal do Estado passa a ser direcionado também para garantir a rentabilidade de aplicações financeiras de investidores privados.

É nesse sentido e nesse contexto que a presente pesquisa vem questionar o papel do planejamento urbano na aroganização das cidades, enquanto ação Estatal - se há uma crise de identidade sistêmica no Estado moderno, a quem ele serve quando decide colonizar novos espaços? Se a soberania popular está enfraquecida diante da hegemonia financeira globalizada, quem está decidindo o futuro da expansão urbana em Ribeirão Preto? 


\section{RETROSPECTIVA HISTÓRICA DA REGULAÇÃO URBANA BRASILEIRA NO CONTEXTO DO PERÍMETRO URBANO}

\subsection{Período Colonial (1500-1822)}

É comum dizer que diferentemente do que ocorreu nas cidades coloniais espanholas, as cidades portuguesas na américa não tiveram o mesmo tipo de preocupação ao organizarem seus traçados e, consequentemente, sua forma de expansão. Há quem diga que essa opção dos portugueses tinha um propósito estratégico, já que as vias tortuosas e fragmentadas se tornavam verdadeiros labirintos para eventuais invasores, atribuindo-se uma função defensiva. Ainda, a ausência de regramentos específicos favorecia a expansão da população para dentro do território sulamericano, legitimando a posse pelo critério uti possidetis $^{8}$ sobre áreas pretendidas pela Espanha (desde que os lucros do comércio real fossem garantidos). É possível inferir, superficialmente, que havia um caráter político e, principalmente, econômico no espalhamento da população sobre o território, favorecido pela "vista grossa" da legislação portuguesa já que a posse legitimaria o direito de explorar as riquezas dos novos territórios.

Embora pudesse existir uma função estratégica no período, há quem diga que a "falta de zêlo" na regulação urbanística colonial tenha contribuído para a cronicidade de problemas nas capitais de província, bem como retardado o desenvolvimento de políticas de planejamento e expansão urbana à época. Para Betina Schürmann, por exemplo, quando Salvador da Bahia deixou de ser capital do Brasil, em 1753, era uma cidade tão medieval quanto Lisboa na véspera das grandes reformas de Pombal. "Não inventaram os portugueses no planejamento de cidades em países novos. Ao contrário dos espanhóis, que eram instruídos por lei a executar um gradeado regular de ruas, que se entrecruzam em torno de uma praça central, os portugueses não mantinham regras, exceto a antiga defesa através da altura". (Schürmann, 1999, p.150 apud Mindlin)

Para a autora, tornou-se axiomático o elogio das cidades da América Espanhola com suas ruas cuidadosamente planejadas sob orientação de uma legislação urbana. Os espanhóis possuíam um código administrativo para ser observado pelos povoadores, enquanto os portugueses se limitavam às Ordenanças do Reino, que cuidavam mais da

\footnotetext{
${ }^{8}$ Utti possidetis ou uti possidetis iuris é um princípio de direito internacional segundo o qual os que de fato ocupam um território possuem direito sobre este. Entretanto, sua origem remonta o direito romano - A expressão advém da frase uti possidetis, ita possideatis, que significa "como possuís, assim possuais".
} 
arquitetura do que da fundação e do planejamento das cidades (SANTOS, 1968, p.38) . A urbanista Raquel Rolnik (1997, p. 17) explica que não existiu um corpo legal específico para aplicações na colônia que criasse uma noção de legalidade urbana, como acontecia na metrópole, extraindo-se apenas regras gerais como nas Ordenações Afonsinas, de 1446, e Manuelinas, de 1521:

Em nenhum desses códigos a questão da ordenação das cidades e critérios para sua fundação ou ainda para sua administração das povoações foram estabelecidas de forma precisa. Ao contrário das ordenanzas de Felipe II da Espanha que, partindo de critérios para a escolha do sítio, determinavam o traçado e definiam, em minúcias burocráticas, as formas de administração do cotidiano da cidade no novo mundo, a legislação portuguesa intervia em questões muito mais de ordem judiciária e fiscal do que propriamente urbanística ou política (ROLNIK, 1997, p. 17)

É defensável que pelo fato de o Brasil ter sido submetido, na década de 1530, a uma política colonial assentada no latifúndio, com produção de açúcar para o mercado europeu e no trabalho escravo, a colônia organizou-se como uma imensa retaguarda rural para os mercados europeus, resultando em um dinamismo centrado no campo. Essa política gerou uma certa atividade urbanizadora, mas o planejamento se restringiu apenas às cidades reais, localizadas no litoral e controladas pela metrópole, que se encarregava do envio de investimentos, de engenheiros militares e de arquitetos. As vilas mais modestas "sem planos, sem diretrizes específicas, nada tinham da disciplina e da ordem formal das cidades hispano-americanas" (REIS FILHO, 1987, p. 355).

Raquel Rolnik (1997, p. 20) elucida que o regime jurídico da propriedade de terras nesse período teve como fundamento a sesmaria (até 1822). Lembrando que essa era uma forma de posse instituída pelo Estado absolutista português em 1375, por D. Fernando I, condicionando-a ao uso produtivo da terra. Caso a obrigatoriedade do cultivo não fosse cumprida, o domínio seria suspenso provisoriamente, sendo possível a cassação definitiva a partir de 1475. No Brasil, seguiu-se essa lógica, sendo as terras do Novo Mundo consideradas de titularidade da Coroa e consignadas à Ordem de Cristo (patrimônio se confundia com o próprio patrimônio da Coroa). A partir de 1530 a "carta para o capitãomor dar terras de sesmaria" instruída por João III a Martim Afonso de Souza introduz uma especificidade em relação à metrópole: A carta de doação permitia ao capitão-mor conceder terras e criar vilas, confirmando-as e regulamentando-as por forais. (A concessão se dava gratuitamente sob exigência de ocupação, desbravamento e cultivo da terra, bem como a obrigação de pagar o dízimo à Ordem de Cristo). 
A atuação das entidades religiosas teve peculiar importância no espalhamento e na regulação dos núcleos urbanos no interior do Brasil, sendo o principal "braço institucional" da coroa nessas localidades. Segundo Murilo Marx (1991, p. 39):

\begin{abstract}
"os patrimônios religiosos eram porções de terra doadas nominalmente a uma devoção, a um santo padroeiro. Passavam a constituir patrimônio deste órgão, e sua capela, administrada por uma entidade que deveria merecer a autorização da Igreja e obedecer também às ordenações do Reino. A garantia de subsistência posterior do tempo se dava muitas vezes através de cessão de parcelas da gleba do santo, do aforamento ou da simples doação. Esse mecanismo configurava uma das formas de organização fundiária dos núcleos urbanos que, na maioria das vezes, se combinava com as datas, espécie de sesmaria urbana. Uma vez constituída a vila, a Câmara detinha o poder de doar e retirar terras, ou seja, cabia à municipalidade a concessão de 'terras e chãos' a partir do rocio da vila"
\end{abstract}

No sistema de sesmaria, assim como no de datas, a condição essencial necessária para estabelecer o domínio era a ocupação efetiva. Cabia à Câmara conceder as datas e zelar pelo cumprimento de tal condição sob pena de a terra voltar ao status de rocio e poder ser concedida a outrem (ROLNIK, 1997,p. 21). Maria Conceição Pires (1996, p. 29) explicita que, no caso de "São Sebastião" do Ribeirão Preto, na primeira metade do século XIX, a doação do patrimônio atendia a certos interesses dos fazendeiros, cada vez mais presentes, e que simpatizavam com a ideia de um núcleo de serviços mais próximo para desenvolver suas atividades econômicas, religiosas e políticas (a vila beneficiava esses empresários com suas atividades terciárias essenciais)

Paula Santoro (2012, p.60) reforça que vários autores descrevem o período colonial como origem estruturadora da nossa forma de ocupação do território, o que é fundamental para explicar a nossa urbanização polarizada e concentrada. Segundo a autora o perfil agroexportador da economia colonial deu às cidades uma face burocrática por serem sede dos aparelhos do Estado controladores das relações entre a economia colonial e a metropolitana:

\footnotetext{
As cidades serão elo de ligação com a circulação internacional de mercadorias (Oliveira, 1982, p.39).Ao contrário de uma imensa teia de aldeias e pequenas cidades padrão característico da urbanização europeia, por exemplo produziuse, por um lado uma extrema polarização, um vasto campo movido pelo conhecido complexo latifúndio e monocultura, que não gerou uma rede urbana de maior magnitude no entorno das próprias regiões produtivas, por outro criou grandes cidades em termos relativos, evidentemente, desde o princípio
}

Essa conformação histórica pode ter formatado modalidades completamente diferentes de urbanização não só externamente, entre metrópole e colônia, como internamente, entre interior e capitais de província. A partir desta noção, Reis (2000) 
constrói a ideia de que a urbanização brasileira, com destaque para o século XIX, avança progressivamente, contrariando grande parte das teses sociológicas de que a urbanização tenha se dado, necessariamente, pela industrialização, mas como uma forma de organização capitalista geral, adaptada às diferentes manifestações e condições do capital. Daí a pretensão de diferenciar os processos de urbanização e a regulação urbanística de grandes centros, capitais de províncias, de cidades interioranas, pela forma específica de colonização do espaço. Justamente porque pode ser que as estruturas político-econômicas que moldam a expansão urbana no interior de São Paulo sejam diferentes das que atuam na capital ou em demais localidades, a depender de suas particularidades específicas no processo de acumulação capitalista.

\subsection{Período Imperial (1822-1889)}

Em 1822, época da independência do Brasil, o sistema de sesmarias foi abolido, seguindo a tendência europeia (Napoleônica) de um modelo de Estado burguês burocrático $^{9}$, passando para a máquina Estatal a gestão das terras rurais e urbanas. É justamente nesse intuito que a constituição brasileira de 1824 , a primeira do país, dedica capítulos à administração, à economia das províncias e um capítulo específico à organização municipal, denominado "Das Comarcas", composto por três artigos:

\section{Das Camaras}

Art. 167. Em todas as Cidades, e Villas ora existentes, e nas mais, que para o futuro se crearem haverá Camaras, ás quaes compete o Governo economico, e municipal das mesmas Cidades, e Villas.

Art. 168. As Camaras serão electivas, e compostas do numero de Vereadores, que a Lei designar, e o que obtiver maior numero de votos, será Presidente.

Art. 169. O exercicio de suas funcções municipaes, formação das suas Posturas policiaes, applicação das suas rendas, e todas as suas particulares, e uteis attribuições, serão decretadas por uma Lei regulamentar.

A pesquisadora Doralice S. Maia (2014, p. 467) analisa o histórico da legislação urbana e explica que muito embora o espí rito burocrático da independência tenha dado certo estímulo às câmaras locais, supondo que o poder municipal conquistaria lugar de

\footnotetext{
${ }^{9}$ Estado moderno entendido "como forma de organização do poder históricamente determinada e, enquanto tal, caracterizada por conotações que a tornam peculiar e diversa de outras formas, historicamente também determinadas e interiormente homogêneas, de organização do poder”. (SHIERA, P. In: BOBBIO, 1986, p. $425-246)$
} 
relevo nas novas instituições políticas da carta de 1824, as decisões continuaram centralizadas na prática. Havia manutenção do poder central imperial, atribuindo uma autonomia pequena e totalmente dependente das relações de poder entre os agentes políticos da Capital e os das Câmaras Municipais.

O mesmo se observa na Carta de Lei de $1^{\circ}$ de outubro de 1828 que regulamentava e padronizava as Câmara Municipais para o tratamento do espaço urbano. Doralice Maia (2014, p. 468) argumenta que as definições dadas por esta legislação ficaram aquém do texto constitucional e do espírito liberal que ela propunha. Em vez de regularem uma vila ou cidade que contasse com uma entidade política local, capaz de administrar as demandas num fluxo hierárquico "de baixo para cima", surgiu um município tutelado e engessado pelo poder imperial. Ou seja, converteu-se o município em peça do mecanismo central.

Além disso, a autora evidencia que as unidades municipais já nasciam carentes de recursos financeiros para viabilizarem todas as atribuições determinadas pelo texto constitucional e pelas leis complementares. Nessa época, os municípios teriam que suprir todas as demandas de melhoramento urbano, de instrução, da saúde e policial, contando com recursos extremamente escassos. "Desta forma, não se atendia às mínimas funções indispensáveis à manutenção dos seus serviços, e ainda estavam sujeitas ao desconfiado e miúdo controle dos conselhos gerais das províncias, dos presidentes de províncias e do governo geral" (MAIA, 2014, p. 468 ). - ou então os recursos eram destinados à serviços e melhoramentos que só atingiam a parcela mais rica desses centro urbanos em formação (PIRES, 1996, p. 30).

Se por um lado esse período pós independência se torna importante por passar o aparato burocrático do poder religioso para o poder estatal, contribuindo para uma máquina pública menos influenciada pelas ordens da Igreja, por outro lado criava relações de dependência na administração local que favoreciam o apadrinhamento político pelo poder central, principalmente via "chantagem" de recursos. Ou seja, a gestão da terra e, por consequência, da expansão das cidades ainda estava à mercê dos grandes oligarcas do império muito embora já houvesse alguma máquina administrativa relativamente consistente.

No que tange aos dispositivos legais especificamente dedicados à delimitação física da expansão urbana, o Decreto de 13 de Novembro de 1832 se destaca por regular a 
criação das novas vilas no império, mencionando a intenção de definir a abrangência territorial delas:

A Regência, em Nome do Imperador,

DECRETA:

$\mathbf{1}^{\circ}$ Para se fazer effectiva a creação de uma Villa, será remettido o Decreto da sua creação, e a designação dos limites do seu termo, á Camara Municipal, á que pertencer o local da nova villa; a qual ordenará aos Juizes de Paz do novo termo que procedam á eleição dos Vereadores. (grifo nosso)

$\mathbf{2}^{\circ}$ Os Juizes de Paz, feitas as eleições, remetterão as listas apuradas á Camara Municipal, que fará a apuração geral; e conhecidos os Vereadores eleitos affixará dia para a sua reunião no local da nova villa, avisando-os por escripto, e fazendo tudo publico por editaes.

$3^{\circ}$ No dia affixado o Presidente da Camara Municipal comparecerá com o Secretario da mesma no lugar da nova villa; e, reunidos os Vereadores, lhes deferirá juramento, e dará posse; e fará lavrar auto da installação, o qual conterá o Decreto da creação, a designação dos limites, o juramento e posse dos Vereadores. Esse auto se fará publico por editaes, e pelos periodicos. (grifo nosso)

Muito embora essas regras sejam gerais e não tratem especificamente de perímetro urbano, que só vai ser mencionado no século XX com o CTN, já se demonstra a consciência do Estado brasileiro no que diz respeito à importância de regular a separação física entre as entidades urbanas em crescimento. A administração pública parece entender, desde esse período, que as atividades ocorridas em um determinado território urbano precisam ser organizadas de uma forma que se viabilize geograficamente a sua gestão (Principalmente evitando choques e conflitos com outras eventuais vilas nas cercanias, posteriormente evitando problemas fitossanitários com animais rurais e cemitérios em locais indevidos no tecido urbano, e etc.) Justamente por ser evidente o peso organizativo da limitação da cidade desde o primeiro império, a presente pesquisa busca ensaiar por quais motivos essa matéria administrativa restou ignorada na ciência jurídica por todos os séculos subsequentes.

\subsection{1 - A Lei de Terras (1850) e a transformação da terra em mercadoria}

D. Pedro II, por Graça de Deus e Unanime Acclamação dos Povos, Imperador Constitucional e Defensor Perpetuo do Brasil: Fazemos saber a todos os Nossos Subditos, que a Assembléa Geral Decretou, e Nós queremos a Lei seguinte:

Art. $1^{\circ}$ Ficam prohibidas as acquisições de terras devolutas por outro titulo que não seja o de compra. 
A promulgação da lei de terras (Lei n. 601 de 18 de Setembro de 1850; BRASIL, 1850) é um marco fundamental na forma de acesso à terra no Brasil, com grandes consequência para o desenvolvimento das cidades. Rolnik (1997, p. 23) defende que a partir de sua promulgação, a única forma legal de posse de terra passou a ser a compra devidamente registrada, o que acarretou em dois grandes efeitos práticos:

a) Absolutização da propriedade, desvinculando a posse como condição efetiva de ocupação da terra, conforme vinha ocorrendo desde o início da colonização.

b) Monetarização da terra, conferindo à terra o estatuto de mercadoria.

A mudança radical no regime territorial não se deu por mera vontade dos administradores, mas por grande pressão diplomática britânica, interessada na inserção plena do Brasil no sistema capitalista, mirando as grandes oportunidades de ganhos e investimento que ela representava (ROLNIK, 1997, p. 24). Pela mesma razão houve grande pressão para a abolição da escravatura, com substituição pela mão de obra livre assalariada - inclusive sob ameaça de intervenção armada inglesa, com ocupação dos portos brasileiros em 1849 e 1850. Não por acaso a própria lei de terras tratava especificamente dessa questão, em seus artigos 17 e 18, determinando verba do Estado para trazer essa população (em sua maioria branca e europeia, frize-se) facilitando sua fixação no território:

\footnotetext{
Art. 17. Os estrangeiros que comprarem terras, e nellas se estabelecerem, ou vierem á sua custa exercer qualquer industria no paiz, serão naturalisados querendo, depois de dous annos de residencia pela fórma por que o foram os da colonia de S, Leopoldo, e ficarão isentos do serviço militar, menos do da Guarda Nacional dentro do municipio.
}

Art. 18. O Governo fica autorizado a mandar vir annualmente á custa do Thesouro certo numero de colonos livres para serem empregados, pelo tempo que for marcado, em estabelecimentos agricolas, ou nos trabalhos dirigidos pela Administração publica, ou na formação de colonias nos logares em que estas mais convierem; tomando anticipadamente as medidas necessarias para que taes colonos achem emprego logo que desembarcarem.

Como se percebe, a intensa e decisiva participação dos cafeicultores paulistas na reformulação da ocupação do território fazia parte de um novo projeto econômico para a nação, baseado no trabalhador assalariado livre e com feições europeias. A Europa, por sua vez, centro do capitalismo à época, se beneficiaria da criação de um imenso mercado consumidor, tanto de seus produtos industrializados como de seus serviços (construção de ferrovias, por exemplo). Isto é, a lei de terras gradualmente substituiu o escravo na 
composição da riqueza, liberando a mão de obra (antes aprisionada) mas aprisionando o espaço territorial (antes "livre"), dando origem à lógica central das conformações urbanas brasileiras modernas. Raquel Rolnik (1997, p. 24) explica que se até então o principal capital do fazendeiro estava investido na pessoa do escravo, imobilizado como renda capitalizada, durante a transição para o trabalho livre o papel de lastro passou para a terra.

Inclusive, através desse estatuto jurídico a terra pôde servir como garantia para direitos reais e então viabilizar a contração de empréstimos bancários, o que foi muito conveniente num momento em que os grandes fazendeiros buscavam financiamento para a expansão dos cultivos. Todos esses fatores influenciaram para a transformação da terra em ativo imobiliário valioso, sujeito à valorização e às disputas típicas do mercado (e, consequentemente, da política).

Nesse contexto, o direito (inclusive o direito urbanístico) funcionou muito mais como um delimitador de acesso a esse recurso tão lucrativo, do que necessariamente um "regulador" da atividade, acirrando e consolidando as já existentes segregações espaciais. Raquel Rolnik (1997, p. 25) sustenta que a "separação entre a propriedade e a efetiva ocupação ocasionou uma transformação radical na forma da cidade, na medida em que aparecem a figura do loteamento ou arruamento, o desenho das ruas e lotes prévios ao próprio ato de construir". Daí se extrai que o desenvolvimento de um projeto de arruamento e, posteriormente, de um planejamento da cidade, possibilitou a divisão do território em "produtos" individualizáveis e comercializáveis, garantindo a venda em massa provendo a segurança jurídica demandada pelo mercado. Essa percepção é fundamental para entender a relação lógica entre o estabelecimento de diversos dispositivos urbanísticos e as lógicas do mercado, incluindo o perímetro urbano vez que sua demarcação tem o poder de abrir novas zonas urbanizáveis (“colonizáveis”).

DECRETO N. 233, DE 2 DE MARÇO DE 1894- O Presidente do Estado, para execução do art. $3 .^{\circ}$ da lei n. 240 , de 4 de Setembro de 1893 , manda que se observe CODIGO SANITARIO - CAPITULO I - RUAS E PRAÇAS PUBLICAS seguinte:

Artigo 26. - Dentro do perímetro urbano não deverá ser permittido conservar terrenos incultos, maltratados e servindo para depositos de lixo 


\subsection{República Velha (1889-1930)}

Sobre esse período, Maria Conceição Pires (1996, p. 47) atribui à proclamação da República (1889) e às transformações político-econômicas em nível nacional e internacional, os fatores que vieram reforçar o urbano como elemento indispensável à expansão da economia. A região de Ribeirão Preto exprime, de forma exemplar, o resultado do desenvolvimento do complexo cafeeiro paulista sendo a região de maior produção de café nesse momento, cuja dinâmica exigiu: um grande contingente de imigrantes; transformou-a na maior receptora de imigrantes, o desenvolvimento da malha ferroviária; a estruturação de uma rede urbana regional; e a consolidação da cidade de Ribeirão Preto como importante polo regional. O complexo cafeeiro é não só efeito, mas condição inerente ao desenvolvimento e a estruturação do sistema urbano, o que dialoga com os elementos fundantes da reprodução capitalista do espaço, ilustrado por David Harvey no primeiro capítulo.

A partir da promulgação da Constituição de 1891, as atividades administrativas internas dos municípios tornaram-se totalmente dependentes dos demais entes federativos vez que não havia um rol de competências estruturado e objetivo, limitando o tema ao vago art. 68 (FILISBINO, 2012): “os Estados organizar-se-ão de forma que fique assegurada a autonomia dos municípios, em tudo quanto respeito ao seu peculiar interesse”. De acordo com Leal (1997, essa estrutura foi propositalmente pensada para alinhar os interesses locais e regionais durante o período do coronelismo (a República café com leite). Muito embora existisse um viés liberal no conteúdo dessa constituição, a falta de determinação em alguns assuntos não visava à beneficiar a livre concorrência das entidades privadas mas criar lacunas a serem dominadas pelo poder oligárquico. O autor reforça que“(...) o princípio da autonomia das comunas ao mínimo compatível com as exigências da Constituição, que eram por demais imprecisas, deixando os Estados praticamente livres, ao regular os $\begin{array}{llll}\text { assuntos" } & \text { (idem, } & \text { 1997, } & \text { 99). }\end{array}$ Sendo assim, ficou evidente que a administração e o planejamento das cidades, sob essa captura de interesses oligárquicos, deu total liberdade aos Estados membros para intervir em assuntos de locais, como por exemplo:
a)
Organizar
b)
c) Definir a
as instituições
municipais.
competência dessas composição do instituições.
d) Definir os tipos de controle que exerceria sobre o município. 
e) Denominar o chefe do poder Executivo. f) Manipular as finanças municipais (IBAM, 2000) .

Segundo Hely Lopes Meirelles (1993, p. 37), a autonomia mencionada constitucionalmente não se concretizou e criou uma dependência institucional entre poder central e poder local, que só começaria a ser questionada décadas mais tarde, já na segunda metade do século XX. Os municípios foram transformados em “(...) feudos de políticos truculentos, que mandavam e desmandavam nos seus distritos de influência, como se o município fosse propriedade particular e o eleitorado um rebanho dócil ao seu poder" (MEIRELLES, 1993, p. 37).

Na política econômica e na administração pública são feitos vários ajustes nas tentativas de recuperação da economia, afetada pelas quedas no preço do café, inclusive com reformas no sistema bancário, introduzindo mecanismos que reforçaram o caráter financeiro tanto do território rural como do crescente território urbano:

\begin{abstract}
"visando a fundamentalmente a expansão da lavoura cafeeira, agora sob novos moldes de crescente especialização e a diversificação de investimentos na indústria e comércio nascentes. A reforma bancária efetuada no início da República, que resultou no 'Encilhamento' (grande dinamismo financeiro e especulativo), propiciou a instalação de várias companhias industriais, casas comerciais e bancos, muitos dos quais tinham na atividade imobiliária - compra e venda de terrenos urbanos, sua base de sustentação" (PIRES, 1996, p. 47)
\end{abstract}

Ainda, no governo de Bernardino de Campos, no comando do Estado de São Paulo (19021904), contemporâneo à presidência de Rodrigues Alves (1902-1906), o imóvel urbano tornou-se hipotecável para fins de crédito agrícola:

LEI ESTADUAL N. 865, DE 17 DE DEZEMBRO DE 1902

Dispõe sobre os Estabelecimentos de Credito Agricola no Estado

Artigo $4 .^{\circ}$ - As operações do banco, respeitadas as bases da legislação federal relativas ao credito agricola movel e aos emprestimos com a garantia pignoraticia ou

hypothecaria,

serão:

I. Por descontos e redescontos:

d) por primeira hypotheca de immoveis ruraes ou urbanos (directa ou por cessão).

DECRETO N. 5614 - DE 29 DE JULHO DE 1905

Approva as alterações feitas nos estatutos do Banco Hypothecario do Brazil.

O Presidente da Republica dos Estados Unidos do Brazil, attendendo ao que requereu o Banco Hypothecario do Brazil, representado por seu presidente João Leopoldo Modesto Leal, resolve approvar as alterações abaixo indicadas feitas nos estatutos do mesmo banco, que a este acompanham: 
Art. 16. A carteira hypothecaria destina-se ás seguintes operações (decreto n. 165 A, de 17 de janeiro de 1890, decreto n. 569 A, de 19 de janeiro de 1890, regulamento que baixou com o decreto n. 370, de 2 de maio de 1890, decreto n. $451 \mathrm{~B}$, de 31 de maio de 1890, e mais disposições em vigor a respeito):

$1^{\circ}$, fazer emprestimos hypothecarios a curto e longo prazo, sob garantia de propriedades urbanas ou ruraes;

$2^{\circ}$, effectuar emprestimos hypothecarios a curto e longo prazo, sob garantia de propriedades ruraes, para compra de machinas, instrumentos agricolas, arames e postes para, cercados, etc

Ambas as leis foram confeccionadas no contexto da crise do café no final do século XIX e começo do século XX, quando os preços da commoditie passavam por quedas recorrentes, o que inclusive culminou no Convênio de Taubaté em 1906. ${ }^{10} \mathrm{O}$ pesquisador em história econômica Fábio Correa (2012, p. 153) chama atenção para o fato de que entre 1899 e 1904 foram inúmeras as leis aprovadas com o intuito de favorecer essas condições de crédito e intervir no mercado de café, principalmente quando a crise se intensificou. (CORREA, 2012, p.153). Isso mostra, mais uma vez, a íntima relação da elite agrária paulista na elaboração de leis que beneficiassem seus interesses econômicos e, de maneira mais incisiva nesse momento, a utilização da terra urbana e rural como lastro financeiro (e garantia real) para os riscos e prejuízos de seus investimentos. Isso obviamente agrega muito mais faculdades econômicas à propriedade de terra e, consequentemente, aumenta seu valor sob a lógica capitalista de colonização espacial. Cria-se, portanto, mais um fator de incentivo à expansão das zonas urbanas, visando extrair do solo os valores e créditos necessários para os processos de acumulação da elite agrária, a despeito de quaisquer intenções abrangentes de planejamento do espaço ocupado e em detrimento do restante da população.

Posteriormente será possível analisar como essa lógica subsiste na "era da cana" em Ribeirão Preto, vez que a terra será mais loteada pelos grandes proprietários em períodos de preços ruins do setor sucroalcooleiro (a cidade invade o campo) e o inverso quando os preços da terra plantada são altos (o agronegócio comprime a cidade). Essa dinâmica será

10 O Convênio de Taubaté de 1906 foi um acordo firmado entre os governadores dos estados de São Paulo (Jorge Tibiriçá), Minas Gerais (Francisco Sales) e Rio de Janeiro (Nilo Peçanha) para proteger a produção brasileira de café, que passava por um momento crítico, de preços baixos e prevendo a colheita de uma safra recorde. Engendrado dentro dos princípios da "Política dos Governadores", acordou-se uma intervenção do Governo federal em benefício da classe dos cafeicultores de determinadas regiões do país. O convênio estabelecia preços mínimos para a compra do excedente pelos governos, que a exportação de tipos inferiores de café fosse desencorajada, que fosse melhorada a propaganda no exterior, que se estimulasse o consumo interno e restringisse a expansão das lavouras. As compras seriam financiadas por emissões lastreadas em empréstimos externos. 
permeada pelo estabelecimento de zonas urbanas e rurais, via legislação de perímetro urbano, objeto dessa pesquisa.

\subsubsection{A herança histórica da Lei de Terras de 1850}

Utilizando ferramenta de busca legislativa estadual, disponível no site oficial da Assembleia Legislativa do Estado de São Paulo, delimitou-se o objeto de pesquisa com a palavra chave "perímetro urbano" bem como foi delimitado o período de abrangência entre 1889 até 1930 . O intuito é analisar se houve menção ou alteração na lei de perímetro urbano e relacioná-las com o contexto político, econômico e histórico recortado.

São inúmeras as menções ao instrumento na legislação da época recortada. Entretanto, na maior parte das vezes, a nomenclatura é usada apenas com o intuito de especificar o local de realização das atividades reguladas (se em espaço urbano ou espaço rural, como por exemplo a abrangência do trabalho de funcionários públicos), tudo muito vago e sem grandes especificações sobre o que é considerado urbano, o que é considerado rural, ou sem utilizá-lo como instrumento de planejamento urbano. Levando em consideração a grande centralidade estadual na atividade legislativa "coronelista", buscouse encontrar menções ao perímetro urbano de Ribeirão Preto nas antigas leis e nos antigos decretos do arquivo da Assembléia Legislativa de São Paulo.

É interessante analisar que dos $43^{11}$ diplomas normativos promulgadas pelo legislativo paulista que mencionam o referido instrumento, 8 deles (18\%) estão direta ou indiretamente envolvidas com questões fitossanitárias. Veja:

\begin{tabular}{|c|c|c|}
\hline Diploma normativo & Conteúdo regulado & Menção ao perímetro \\
\hline $\begin{array}{l}\text { Decreto } \mathrm{n}^{\mathrm{o}} \quad 233 \text {, } \\
\text { de } 02 / 03 / 1894\end{array}$ & $\begin{array}{l}\begin{array}{l}\text { Estabelece } \\
\text { sanitário. }\end{array} \\
\text { o código }\end{array}$ & $\begin{array}{l}\text { Artigo 26. - Dentro do } \\
\text { perímetro urbano não deverá } \\
\text { ser permittido conservar terrenos } \\
\text { incultos, maltratados e servindo } \\
\text { para depositos de lixo. }\end{array}$ \\
\hline $\begin{array}{l}\text { decreto } \mathrm{n}^{\mathrm{o}} \quad 708, \\
\text { de } 18 / 09 / 1899\end{array}$ & $\begin{array}{l}\text { Dá regulamento para } \\
\text { instalação domiciliar de } \\
\text { esgotos. }\end{array}$ & $\begin{array}{l}\text { Artigo } 2^{\circ} \text { - Em toda a habitação } \\
\text { dentro do perimetro urbano } \\
\text { haverá um gabinete para a latrina } \\
\text { e demais apparelhos sanitarios, }\end{array}$ \\
\hline
\end{tabular}

11 http://www.al.sp.gov.br/alesp/pesquisalegislacao $/$ ?status $=$ G\&inicio $=40 \&$ fim $=50 \&$ autor $=\&$ texto $=$ per $\%$ EDmetro + urbano $\&$ tipo $=\&$ numero $=\&$ ano $=$ \&dataIni $=01 \% 2 \mathrm{~F} 01 \% 2 \mathrm{~F} 1800 \&$ dataFim $=01 \% 2 \mathrm{~F} 01 \% 2 \mathrm{~F} 1930 \&$ indexadores $=\&$ tema=\&idAutor=\&situacao= \&promulgacao= 


\begin{tabular}{|c|c|c|}
\hline & & $\begin{array}{l}\text { nas condições previstas nos } \\
\text { paragraphos que se seguem (...) }\end{array}$ \\
\hline $\begin{array}{l}\text { decreto } \mathrm{n}^{\mathrm{o}} \\
\text { de 03/12/1904 }\end{array}$ & $\begin{array}{l}\text { Dá regulamento para a } \\
\text { cobrança da taxa de } \\
\text { esgotos na cidade de } \\
\text { santos. }\end{array}$ & $\begin{array}{l}\text { Artigo 20. - Incumbe ao auxiliar } \\
\text { designado pela Repartiçao do } \\
\text { Saneamento } \\
\text { 1. }{ }^{\circ} \text { ) Acompanhar o serviço de } \\
\text { lançamento dentro do perimetro } \\
\text { urbano o principalmente dentro } \\
\text { da zona servida de exgottos, } \\
\text { auxiliando esse trabalho e } \\
\text { fornecendo os esclarecimentos } \\
\text { que não constarem da relação } \\
\text { cadastral. }\end{array}$ \\
\hline $\begin{array}{l}\text { decreto } \quad \mathrm{n}^{\mathbf{0}} \\
\text { de } 08 / 02 / 1906\end{array}$ & $\begin{array}{l}\text { Declara de necessidade } \\
\text { pública, para serem } \\
\text { desapropriados } \\
\text { estado, terrenos adjacentes } \\
\text { à linha adutora das águas } \\
\text { do cabuçu. }\end{array}$ & $\begin{array}{l}\text { Artigo unico. - São declarados } \\
\text { de necessidade publica, para } \\
\text { desapropriação pelo Estado, na } \\
\text { forma da lei, terrenos de } \\
\text { propriedade particular, } \\
\text { comprehendidos numa faixa de } \\
\text { vinte metros para cada lado da } \\
\text { linha adductora das aguas do } \\
\text { Cabuçú, desde a barragem desse } \\
\text { nome até o perimetro urbano }\end{array}$ \\
\hline $\begin{array}{l}\text { decreto } \quad \mathrm{n}^{\mathrm{o}} \\
\text { de } 14 / 11 / 1911\end{array}$ & $\begin{array}{l}\text { Reorganiza o serviço } \\
\text { sanitário do estado. }\end{array}$ & $\begin{array}{l}\text { Artigo 170 - Os resíduos solidos } \\
\text { des fabricas e officinas que não } \\
\text { forem utilisaveis serão } \\
\text { incinerados ou removidos para } \\
\text { fóra do perimetro urbano. }\end{array}$ \\
\hline $\begin{array}{l}\text { decreto } \quad \mathrm{n}^{\circ} \\
\text { de } 09 / 04 / 1918\end{array}$ & $\begin{array}{l}\text { Dá execução ao código } \\
\text { sanitário do estado de São } \\
\text { Paulo. }\end{array}$ & $\begin{array}{l}\text { Artigo 207. - Os residuos } \\
\text { solidos das fabricas e officinas } \\
\text { que não forem utilisaveis serão } \\
\text { incinerados ou removidos para } \\
\text { fóra do perimetro urbano } \\
\text { Artigo 410. - E vedado ter } \\
\text { porcos dentro dos quintaes ou } \\
\text { crial -os dentro do perimetro da } \\
\text { cidade. (Art. 182, lei 1.596). } \\
\text { Pena de multa de cem mil réis e } \\
\text { o dobro nas reincidências }\end{array}$ \\
\hline lei $\mathrm{n}^{\circ} 2.259$, de 31/12/1927 & $\begin{array}{l}\text { Modifica as disposições do } \\
\text { código sanitário, } \\
\text { relativamente a construção } \\
\text { de hospitais, casas de saúde } \\
\text { e maternidade. }\end{array}$ & $\begin{array}{l}\text { Artigo } 10^{\circ}-\$ 10^{\circ} \text { - No perimetro } \\
\text { urbano das cidades, em ruas } \\
\text { pavimentadas a pedra, asphalto } \\
\text { ou material semelhante poderão } \\
\text { ser construidos no alinhamento } \\
\text { das ruas mantendo porém, a } \\
\text { distancia minima de cinco } \\
\text { metros, com os terrenos } \\
\text { visinhos. }\end{array}$ \\
\hline $\begin{array}{l}\text { decreto } \mathrm{n}^{\circ} \\
\text { de } 03 / 10 / 1929\end{array}$ & $\begin{array}{l}\text { Regulamenta a lei } n^{\circ} 2362 \text {, } \\
\text { de } 14 \text { de janeiro deste ano, } \\
\text { que deu organização às } \\
\text { prefeituras sanitárias de } \\
\text { campos do Jordão e } \\
\text { Guarujá. }\end{array}$ & $\begin{array}{l}\text { Artigo } 331 \text { - Perimetro urbano } \\
\text { é aquelle onde existem ruas e as } \\
\text { edificações se acham mais } \\
\text { aglomeradas e suburbano } \\
\text { aquelle onde estas são muito } \\
\text { distantes uma das outras. }\end{array}$ \\
\hline
\end{tabular}


Tabela 1: Tipos normativos estaduais que mencionam a palavra "perímetro urbano" em Ribeirão Preto, no período oligárquico (1889-1930)

O período coincide com a grande epidemia de febre amarela que assolou o Estado no começo do século $\mathrm{XX}^{12}$, gerando diversas consequências tanto na administração pública quanto no formato da cidade, conforme será demonstrado com as mudanças de cemitério em Ribeirão Preto, beneficiando bairros valorizados. A doença se espalhava muito rapidamente graças às ferrovias, agora carregadas com imigrantes de todo canto da Europa, o que gerou preocupação por parte dos governantes não só pela integridade física da população mas também pelo risco de perda massiva de mão de obra que estava sendo importada a grandes custas (poderia colocar em cheque o projeto de nação branca livre e assalariada que os oligarcas brasileiros outrora planejaram).

Segundo Rolnik (1997, p. 43) muito embora essas leis tivessem sim o intuito de proteger a população das enfermidades decorrentes da falta de saneamento básico e tenham, de fato, ajudado a tornar o ambiente urbano mais salubre, elas também tiveram um papel muito importante na segregação espacial das cidades. A utilização do discurso técnico higienista, de que o poder de polícia era empregado por questões fitossanitárias, justificava uma série de abusos e oportunismos nos bairros mais pobres e encortiçados, vítimas da especulação imobiliária. "Como se tratava de penetrar no território popular com o objetivo de controlar para poder transformar, o sanitarismo forneceu à política repressiva do Estado os meios legais e institucionais para cumprir tal missão" (ROLNIK, 1997, p. 42)

Em “A cidade e a Lei”(1997, p.43), a autora evidencia que o próprio diretor de obras da cidade e São Paulo no período admitiu ser um dos intuitos da legislação sanitária a "repressão e policia - impedir que a parte restante da população, a qual pouco se importa com tudo isso, ou é incapaz de tentar o esforço necessário para o alcançar, possa crear situações que venham a constituir ameaça para os visinhos para a communidade e para a civilização".

Esse discurso pragmático dos engenheiros foi sensivelmente útil ao lobby dos empreendedores imobiliários. Foi reiteradamente massificada a ideia de que os avanços da técnica urbanística permitiriam garantir condições adequadas (higiênicas) e, simultaneamente, fazer investimentos urbanos altamente lucrativos (ROLNIK, 1997, p. 44). Com isso, muitos cortiços e demais moradias tidas como anti-higiênicas que se

\footnotetext{
${ }^{12}$ A população de Campinas, por exemplo, foi de aproximadamente 15.000 para não mais que 5.000 em 1900 - Ribeiro, Maria Alice Rosa. "Uma historia sem fim-um inventario da saude publica: São Paulo, 1880-1930." (1991).
} 
encontravam em regiões valorizadas, foram institucionalmente removidos para dar lugar a empreendimentos mais "limpos", expulsando a população mais pobre para regiões mais afastadas e com infraestrutura ainda mais pobre (gentrificação).

Além do código sanitário de 1894, que embasava esse argumento, a Lei municipal 498 de 1900 isentou de impostos municipais os proprietários que construíssem vilas operárias de acordo com o padrão municipal paulistano, fora do perímetro urbano, esse que seria delimitado pela mesma lei (inclusive essa política previa a concessão de terrenos municipais para a construção de moradias populares em lugares "apropriados" - fora da área urbana.). Para Raquel Rolnik (1997, p.48), a conjunção desses fatores e a utilização do perímetro como linha social contribuiu para criar verdadeiros muros na cidade: para dentro, o comércio, as fábricas não incômodas e a moradia da elite; para fora, a habitação popular "e tudo que cheira mal, polui e contamina (matadouros, fábricas químicas, manicômios e etc)". Assim, a capital exportou um formato dualista de manejar a expansão das cidades, determinando que : a) na zona urbana, central, as regras eram rígidas e extremamente custosas de serem cumpridas pela grande maioria (como a exigência de se fazer recuos, a existência de jardins e etc), limitando o tipo e a classe social de quem pudesse se instalar em regiões mais beneficiadas pelo planejamento e pela infraestrutura; b) a zona rural, periférica, seria "terra de ninguém" onde um diferente estamento de legalidade teria características mais permissivas, seria uma zona menos planejada, com menos investimentos públicos e que sequer exigia plano de arruamento para loteadores que quisessem explorá-la.

No mesmo rol dos 43 instrumentos normativos apresentados, $7^{13}$ deles $(16,2 \%)$ mencionam o perímetro urbano como delimitador da incidência geográfica de tributos, o que evidencia o potencial de influência desse instrumento administrativo em questões arrecadatórias. A ideia de perímetro como um planejamento espacial ainda não estava consolidada, entretanto, em determinadas matérias mais sensíveis ao interesse da classe governante parece ter ocorrido uma maior exploração da questão. Destaca-se o decreto n. 982 de 1901, que regula a cobrança de imposto predial e taxa de esgoto na capital estadual:

DA DEMARCAÇÃO DO PERIMETRO URBANO PARA OS EFFEITOS DO IMPOSTO PREDIAL

\footnotetext{
${ }^{13}$ Lei no $^{\circ}$ 576, de 27/08/1898; Decreto no 982, de 07/12/1901; RESOLUÇÃO N. 1.023 DE 1906; DECRETO N.1.450 de1907; Decreto $\mathrm{n}^{\circ}$ 2.621, de 24/12/1915; Lei $\mathrm{n}^{\circ}$ 1.439, de 19/12/1914; Resolução $\mathrm{n}^{\circ} 5$, de $30 / 10 / 1914$
} 
Artigo 13. - A demarcação dos limites da cidade ou perimetro urbano, para a cobrança do imposto predial, será feita de dous em dous annos, por meio de uma commissão.

Artigo 14. - A commissão a que se refere o artigo antecedente, será composta do presidente da camara municipal ou outro vereador que a camara designar, do procurador fiscal do Estado e do engenheiro-chefe da repartição a cujo cargo estiverem os serviços de exgottos da cidade ou de um engenheiro que for por este designado.

Artigo 15. - Feita a designação dos limites urbanos, será publicada pela imprensa e se enviará cópia do termo ao secretario da Fazenda, até o dia 15 de Dezembro, para ser approvado.

Artigo 16. - Da approvação do perimetro urbano, haverá recurso voluntario para o presidente do Estado, por qualquer pessoa interessada, interposto dentro do prazo de oito dias e apresentado na Secretaria da Fazenda, dentro de trinta dias.

Artigo 17. - A commissão demarcadora do perimetro urbano iniciará e terminará os seus trabalhos no ultimo trimestre do biennio, de modo que a cópia do termo de demarcação seja enviada á Secretaria da Fazenda, na epocha fixada no artigo 15 .

Esse decreto surpreende tanto pela especificação inédita que dá para a matéria quanto pela tecnicidade com que trata a demarcação de espaços tão complexos, e com um rol estritamente selecionado de membros políticos e técnicos para a feitura. Além disso, é possível vislumbrar uma maior necessidade do Estado em regular e tornar eficiente a captação de recursos via impostos prediais e taxas de serviço público, talvez na tentativa de aproveitar o aumento de potencial arrecadatório com a urbanização crescente. A ideia parece bem conveniente para o momento de crise econômica e queda de receita com as inconstâncias da exportação de café.

Vale ressaltar, como mencionado anteriormente, que era comum o governo oligárquico socializar os prejuízos sentidos pela crise cafeeira e assim manter os altos rendimentos dos barões. Sendo assim, é possível especular que esse decreto talvez tivesse a intenção de tornar a arrecadação mais eficiente e acurada na crise justamente para amortizar o baixo rendimento dos grandes fazendeiros vez que o governo utilizava recursos públicos para manter os preços do café virtualmente altos. (Daí, talvez, uma primeira hipótese de consequência indireta da alteração do perímetro urbano como instrumento indutor de concentração de renda, ao contrário de racionalizador do espaço urbano. Obviamente, toda essa discussão mais aprofundada não caberia aqui pela falta de tempo e embasamento científico) 
Apesar de lançar muitas hipóteses negativas sobre a demarcação do perímetro, o referido decreto destaca-se , também, por admitir recurso voluntário, no artigo 16, evidenciando a administração pública brasileira em direção à construção de Estado moderno, de inspiração francesa, minimante preocupado com o consentimento do administrado em relação aos atos da administração pública, muito embora a utilização de fato dependesse das relações de poder do coronelismo.

\subsection{O período populista: da Era Vargas a João Goulart (1930 - 1964)}

A crise de 1929 agravou a crise econômica e ajudou a sucumbir a Velha República, também em crise política. Ermínia Maricato (2001, p. 45) salienta que apesar de o processo brasileiro de urbanização ter se dado com maior intensidade a partir desse século XX, também foi conservado, como se percebe, muitas raízes da sociedade patrimonialista e clientelista próprias do Brasil pré-republicano: "O patrimonialismo impediu o surgimento da esfera pública, alimentando o fisiologismo, o paroquialismo, o clientelismo e o privilégio que é possível constatar até mesmo numa Câmara Municipal da mais poderosa cidade brasileira como é o caso de São Paulo, em pleno ano 2000.

A autora ainda faz um resgate da teoria de Lefebvre, argumentando que no contexto do desenvolvimento capitalista do período a construção das cidades foi , em grande parte, reprodução da força de trabalho e exprime, portanto, a feição material das relações de exploração entre as classes. Ainda, uma vez que Estado é "a expressão das classes dominantes, torna-se inviável um planejamento urbano democrático e igualitário". (MARICATO, 2001,p.48)

Com base nisso, a gestão municipal, durante essa primeira experiência republicana, reproduziu as relações de favor em detrimento das diretrizes de qualquer plano holístico de gestão, privilegiando as elites que se mantiveram no poder desde o período colonial, adaptando-se à entrada no capitalismo periférico. Isso viria a refletir, posteriormente, em práticas corriqueiras como a utilização de recursos do Orçamento Geral da União (os poucos que são distribuídos com subsídios ou a fundo perdido, pelo governo federal) através de emendas parlamentares para atender as bases políticas. "Esses investimentos pontuais negam o planejamento dos investimentos e reafirmam a relação de dependência e de favor". (MARICATO, 2001, p. 45)

Quanto ao contexto político do período, o Brasil esteve sob a administração do presidente Getúlio Vargas, "O Estado Getulista”, como ficou conhecido (entre 1930 e 
1945). Após sucessivas crises políticas no final da república velha, Vargas ascendeu provisoriamente ao poder e adotou fortes medidas centralizadoras. O estadista controlava tanto o Poder Executivo quanto o Poder Legislativo, dissolvendo o Congresso Nacional e, em 1934, promulga uma nova constituição que garantia o voto secreto e direto, bem como introduzia novos mecanismos administrativos burocráticos para fortalecer a máquina Estatal. Entretanto, em 1937, essa mesma Carta foi derrubada e instaurou-se a ditadura do Estado Novo. O regime foi marcado pela centralidade das políticas trabalhistas, fortalecidas por leis de proteção ao trabalhador e pelo crescimento econômico, que só seria interrompido em 1945, com o golpe militar. A partir de então inicia-se o período democrático e Getúlio só retornaria à presidência pelo voto direto, permanecendo até 1954, quando se suicidou. A década de 1950 foi marcada pela presidência desenvolvimentista de Juscelino Kubitschek, pela inauguração de Brasília, e pelo grande incentivo a industrialização, tida como solução para alavancar o progresso econômico do país. (LEONELLI, 2010, p. 75)

\subsubsection{As Constituições de 1934 e 1937.}

CF 1934, Art 124 - Provada a valorização do imóvel por motivo de obras públicas, a administração, que as tiver efetuado, poderá cobrar dos beneficiados contribuição de melhoria.

Como mencionado, era corriqueira a utilização de investimentos públicos para a valorização imobiliária de determinados setores mais abastados da sociedade, enquanto os serviços indesejáveis (desvalorizáveis) eram colocado no bairros mais pobres, geralmente fora do perímetro urbano. (inclusive em Ribeirão Preto, na época da febre amarela). Nesse sentido, a Constituição Federal de 1934 apresentou avanço com a introdução da figura da Contribuição de Melhoria, assumindo a alteração de valor causada pela atividade administrativa (desde que provada a valorização). Paula Santoro (2012,p. 64) argumenta, no entanto, que só na Constituição de 1966 que a matéria será melhor regulamentada e, portanto, melhor utilizada para os fins que foi criada.

A Constituição de 1937 foi outorgada num contexto de grandes disputas políticas, instaurando autoritariamente o poder do presidente Getúlio Vargas. Essa Carta recebeu o apelido de "Polaca" em função de sua inspiração no modelo semifascista polonês, que concedia ao governo poderes praticamente ilimitados. Sendo assim, as poucas garantias e liberdades conquistadas na última constituição foram dissolvidas pelo Estado Novo, que centralizou ainda mais administração pública nas mãos do governo central. (o Art 27, por 
exemplo, determina que o "Prefeito será de livre nomeação do Governador do Estado", reforçando o clientelismo político)

Mais uma vez é interrompida a disputa por maior autonomia no planejamento urbano e, consequentemente, interrompe o acesso das camadas mais populares às decisões políticas locais (muito embora já houvesse grande atividade dos movimentos populares reivindicando mais direitos nesse aspecto). É certo que o governo Vargas tinha grande apelo político com as grandes massas trabalhadoras, entretanto, as decisões políticas mais determinantes ainda passavam pela negociação e pelo crivo das grandes elites (agrária, financeira, industrial). Sem esse "pacto" o governo seria inviável e, sendo assim, a centralidade administrativa do governo continuou a privilegiar essas "castas superiores" quando dos seus interesses na política urbana.

\subsubsection{O Decreto Lei $58 / 1937$}

Ainda que Vargas tenha assegurado as suas rédeas sobre a gestão pública ,era inegável que o Brasil tivesse passado por mudanças inequívocas no padrão de acumulação, cuja importância da agricultura sofreu considerável queda em relação à indústria, e que portanto haviam mudanças contundentes acontecendo no processo de urbanização. Independente da posição política, demandavam-se novas formulas jurídicas de organizar o território.

Nesse contexto destaca-se a intenção do poder público em regular o parcelamento do solo que já vinha acontecendo de maneira frequente desde o começo do século, se comportando como um importante vetor da expansão urbana no período. Em 1937 foi elaborada a primeira legislação federal de parcelamento do solo (DL 58/1937) e a primeira regulação das florestas nacionais:

Considerando o crescente desenvolvimento da loteação de terrenos para venda mediante o pagamento do preço em prestações;

Considerando que as transações assim realizadas não transferem o domínio ao comprador, uma vez que o art. 1.088 do Código Civil permite a qualquer das partes arrepender-se antes de assinada a escritura da compra e venda;

Considerando que êsse dispositivo deixa pràticamente sem amparo numerosos compradores de lotes, que têm assim por exclusiva garantia a seriedade, a boa fé e a solvabilidade das emprêsas vendedoras ;

Considerando que, para segurança das transações realizadas mediante contrato de compromisso de compra e venda de lotes, cumpre acautelar o compromissário contra futuras alienações ou onerações dos lotes comprometidos; 
Considerando ainda que a loteação e venda de terrenos urbanos e rurais se opera frequentemente sem que aos compradores seja possível a verificação dos títulos de propriedade dos vendedores; DECRETA:

Art. $1^{\circ}, \mathrm{V}-\S 1^{\mathrm{o}}$ : Tratando-se de propriedade urbana, o plano e a planta de loteamento devem ser prèviamente aprovados pela Prefeitura Municipal, ouvidas, quanto ao que lhes disser respeito, as autoridades sanitárias, militares e, desde que se trata de área total ou parcialmente florestada as autoridades florestais (grifo nosso)

Paula Santoro (2012, p. 63) argumenta que o Decreto-Lei n 58/37 foi solução do legislador federal para tentar ordenar a já conflituosa expansão urbana através de loteamentos vez que na esfera municipal já existiam leis locais que tratavam do parcelamento, mas de maneira dispersa. O dispositivo esperava, ao mesmo tempo, criar uma proceder unificado para questão e transferir para os municípios determinadas autonomias de regramento, em escala local. Vale ressaltar que já haviam as licenças para arruar no início do século, o que significava um importante avanço na autonomia municipal sobre a gestão da expansão urbana (sem necessidade de chancela de outro ente federativo). No entanto, é só a partir do Decreto n 58/37 que a administração local passa a ter maior poder de decisão sobre o parcelamento do solo em seu território (Leonelli, 2010, p.41). Esse é um ponto muito importante para se entender a dinâmica do crescimento urbano vez que até hoje grande parte da colonização do espaço se dá por mecanismos de parcelamento.

Conforme evidenciado pelas exposições de motivos iniciais do DL 58/37, o Art. 1.088 do Código Civil de 1916 permitia "a qualquer das partes arrepender-se antes de assinada a escritura da compra e venda;" no caso dos lotes vendidos à prazo. Isto é: ainda que já houvessem sido quitadas as prestações contratuais, ao proprietário era garantido o direito de arrepender da venda e reaver a propriedade, o que gerava grande insegurança jurídica (principalmente para empresários e investidores imobiliários). Dessa forma, se a lei de Terras foi um marco para a transformação da terra em mercadoria, esse Decreto destacou-se por aumentar a "eficiência" contratual no parcelamento do território urbano. Ainda, esse dispositivo tanto reforçou o caráter comercial do solo quanto favoreceu a proliferação de loteamentos nas periferias do país, de forma clandestina, beneficiando o modelo periférico de ocupação urbana. O escopo desta regulação, neste momento, não parecia ser o de combate à ilegalidade e de busca da qualidade urbanística. "Não havia penalização ao loteador clandestino e havia expectativa de anistias e de investimentos em infraestrutura que deveriam chegar, posteriormente, a partir de intervenções públicas." (SANTORO, 2012, p. 72) Isto é: manteve-se a mesma lógica de suburbanização como uma alternativa altamente lucrativa de utilização das terras. 
De maneira geral, Sarah Feldman (2007 e 2009, apud, Leonelli,2010, p. 75) elucida que a década de 1930 foi também marcada pelo esforço de institucionalizar o urbanismo e o planejamento urbano do Brasil, com o estabelecimento de novos órgãos administrativos municipais voltados ao planejamento e de instituições na área. Segundo a autora, é nesse momento que a atividade urbanística começa a exigir o tratamento de uma tarefa técnico-administrativa, demandando profissionalização e especialização tanto dos funcionários quanto da legislação. Não é à toa que, no período, levantou-se o debate pela formulação de um código urbanístico nacional, em que se discutia o condicionamento da aprovação de loteamentos a um plano municipal que determinasse as diretrizes da expansão urbana, daí a preocupação em vincular o parcelamento ao respeito de critérios ambientais, sanitários, militares, como consta no artigo $1^{\circ}$ do decreto mencionado. (LEONELLI, 2010) .Por esses motivos, no que tange à regulação do parcelamento do solo no Brasil, é recorrente a definição do Decreto Federal 58/37 como o primeiro momento desta natureza, sendo que o tema só seria retomado em 1979, com a lei federal 6.766. Isso mostra que, apesar deter recebido muitas críticas e ter privilegiado os processos de especulação imobiliária, o referido decreto foi o único dispositivo federal a regular o tema (principalmente rural transformado em urbano) durante um dos períodos mais críticos da transformação territorial, o que ajuda a explicar muito da cronicidade de alguns problemas.

\subsubsection{Habitação Social e Expansão Urbana na era Vargas}

Paula Santoro (2012, p. 64) explicita que o Governo Getúlio Vargas, ao final dos anos 1930, teve um papel bastante interventivo no mercado de habitação, controlando os preços de aluguel, incentivando a produção de moradias com crédito e assegurando tais benefícios com a nova lei do inquilinato de $1942^{14}$. Essa nova política habitacional, além de ter grande apelo político à classe trabalhadora, estimulou a produção direta e o financiamento da moradia. Essas medidas, combinadas com a política desregulada de expansão urbana, incentivou o alastramento das cidades para além de seus perímetros urbanos, engolindo boa parte da zona rural:

\footnotetext{
“(...) surgem iniciativas de produção de habitação social a partir de cooperativas ou institutos organizados a partir de fundos de categorias profissionais, e promove uma série de medidas de complementação urbana na periferia, com grandes investimentos no transporte rodoviário que viabilizará o crescimento em extensão, principalmente nas grandes cidades onde a indústria irá se desenvolver." (SANTORO, 2012, p. 62)
}

14 Decreto-Lei no 4.598, de 20 de Agosto de 1942 
A política habitacional interna das grandes cidades acompanhou a tendência do governo central. Em São Paulo, por exemplo, era muito difundida a ideia de revisão das Posturas Municipais, incentivando a desregulação da zona rural como estratégia chave de barateamento da terra para que o operariado pudesse ocupá-lo. A tese de Paula Santoro (2012, p.65) traz um exemplar da Revista do Arquivo Municipal de São Paulo ,de 1942, em que técnicos e gestores sugeriram a revisão do Código de Obras e o Código Estadual Sanitário, retirando obrigatoriedade de recuo em ambas as laterais do terreno para casas na zona rural, bem como isenção do imposto para transmissão de um lote, em primeira compra, nas zonas em que o zoneamento designasse como operárias ou populares (Barbosa, 1942, apud SANTORO, 2012).

A autora ressalta que a mesma publicação também indicou os principais problemas já existentes na zona rural, como a ausência de transporte coletivo, grandes despesas com condução, falta de infraestrutura urbana. Em muitos casos a zona rural foi loteada, ocupada e ainda era abastecida por água de poço, esgoto em fossa, luz de lampião e carvão no lugar de gás (Bonduki, 1998, p.91-93 apud SANTORO, 2012, p. 65). Também em São Paulo, no mesmo período cria-se jurisprudência permitindo que o dono de lote construísse sua casa em uma rua não-oficial," desde que obedecesse o Código de Obras, sob o argumento de que a responsabilidade de abrir e pedir autorização para oficializar uma via, era do loteador, e a construção da casa, do proprietário do lote. Desta forma, viabilizava-se a ocupação sobre loteamentos ainda precários e clandestinos" (SANTORO, 2012, p. 67)

Ainda, o congelamento dos aluguéis decretados em 1942 e invariavelmente renovado nos anos seguintes, criou condições desfavoráveis para investidores em casas de aluguel e aumentou o número de despejos nas principais cidades do país. Dessa população desabrigada, muitos recorreram às regiões limítrofes da cidade e a zona rural (mais baratas) em busca de espaço para autoconstrução ou moradias mais acessíveis, formando as primeiras favelas e agravando o recorrente inchaço das periferias. Raquel Rolnik (1997, p. 202) ilustra que a invasão da zona rural foi historicamente associada a um modelo de cidade que destina suas periferias aos pobres, isto é, a desregulação das regiões limítrofes não é um mero vácuo legislativo mas um tipo bem delimitado de política urbana que privilegia determinados setores da cidade. A autora recorre ao termo "urban fence 15 " para determinar o caráter segregacionista do perímetro urbano nesse contexto, cuja região interna (zona

\footnotetext{
${ }^{15}$ Cercas urbanas (tradução livre)
} 
urbana) tinha os preços artificialmente inflados por uma legislação urbana rígida e empurrava os arruamentos populares para as áreas rurais.

Esse cenário se agrava após a segunda guerra mundial. Com as grandes potências industrias europeias destruídas houve grande demanda para a produção fabril no Brasil, espalhando o parque industrial pelas periferias das grandes cidades (principalmente São Paulo). Como consequência, a população urbana também aumentou, atraída pela oportunidade de mão de obra, induzindo as administrações municipais a aumentar consideravelmente os impostos territoriais tendo em vista a necessidade de captação de recursos para prover a infraestrutura dessa urbanização "a galope". O resultado geral foi o aumento do custo de vida nas zonas urbanas mais centralizadas e privilegiadas. (SANTORO, 2012)

\subsubsection{O urbanismo no Pós-guerra e na Redemocratização}

O artigo 28 da nova constituição de 1946 trouxe novamente a possibilidade de eleger diretamente representantes no poder executivo e legislativo, inclusive municipais. $\mathrm{O}$ período de redemocratização reacendeu o debate sobre o planejamento urbano e deu força aos questionamentos quanto à efetividade do DL 58-37 em controlar o parcelamento do solo. Gisela C. Leonelli (2010, p. 98) cita a Lei de Formação de Centros Povoados do Uruguai, aprovada em 1946, como referência para a elaboração de uma nova lei federal na matéria. Esse dispositivo estabelecia que:

a) os planos de loteamentos deveriam ser elaborados por urbanistas.

b) deveriam ser apresentados os recursos naturais existentes, as soluções para abastecimento de água, de salubridade, de comunicação, as características do terreno além dos preços da terra e dos títulos de propriedade.

c) definia o percentual de áreas livres, áreas ocupadas, e a localização de edifícios educacionais coerente com a distribuição da população.

d) reforçava que os planos diretores em elaboração teriam pouco alcance sem a aprovação de uma lei federal para disciplinar a expansão das novas áreas urbanas.

É possível perceber semelhanças com o conteúdo do atual estatuto das cidades (L. 11.257 de 2001), principalmente no que tange à preocupação com a valorização do solo a ser urbanizado. Isso mostra que os problemas decorrentes da supervalorização dos solos urbanizados (inclusive rurais urbanizados) já eram reconhecidos pela administração pública da época, no entanto, só foram contemplados com mecanismos jurídicos federais de captura da mais valia a partir de 2001 (e.g. outorga onerosa de transformação de uso). 
Isto é, são 55 anos de crescimento urbano sem munir o cidadão de dispositivos jurídicos que permitissem mitigar os efeitos da valorização do solo, favorecendo grandes investidores com influência na administração pública.

Ainda que as prefeituras tivessem alguma autonomia no controle dos loteamentos e na cobrança das exigências legais previstas localmente, a grande hegemonia da política urbana em torno do governo central ainda fragilizava a competência municipal, o que demandava criação de uma lei federal na matéria (LEONELLI, 2010, p. 98). Sobre o assunto, a autora cita a contribuição de Hely Lopes Meirelles na seção "Doutrinas" da Revista dos Tribunais de 1959 (ano 48, vol. 281, p. 7-34), cujo texto provoca o debate acerca das "Limitações Urbanística ao Uso da Propriedade". Nesse texto o jurista esclarece dúvidas sobre o caráter jurídico da legislação vigente sobre loteamentos na época, baseada no DL n58/37, e sugere com razoabilidade uma melhor distribuição das confusas competências municipal-União. (LEONELLI, 2010, p. 99)

O jurista (MEIRELLES, 1959) define como “orgia de loteamentos" a estrutura jurídica construída sobre a matéria urbanística no Brasil, até aquele momento. Para o autor, o decreto 58 de 1937 não pormenorizava as diretrizes urbanísticas de novos parcelamentos e loteamentos, deixando subjetivas inclusive questões técnicas que em tese fundamentavam o dispositivo. As únicas exigências mais claras diziam respeito às questões burocráticas de documentação e transação comercial dos lotes, com caráter administrativo, oportunamente delegando o controle dessas operações para as instâncias municipais. Entretanto, diante da administração local enfraquecida na matéria, a fiscalização não se efetivava. Desta forma, a orgia dos loteamentos se instalava "provocada por uma valorização imobiliária fictícia, transformando áreas rurais em loteadas apenas pela aprovação, sem infraestrutura alguma, sem melhoramentos, promovendo a desordem do crescimento urbano." (LEONELLI, 2010, p. 99):

Para Modesto (1959 apud LEONELLI, 2010, p. 100), esta conformação jurídicourbanística contribuía para uma inversão do princípio do planejamento, levando serviços públicos e infraestrutura sempre depois que a terra é ocupada, aumentando custos e inconveniências tanto para o cidadão (geralmente morador de regiões periféricas, que "se vira" com autoconstrução), quanto para a administração pública (geralmente com orçamento escasso). $\mathrm{O}$ autor ainda aponta que os profissionais técnicos geralmente não estavam envolvidos nos processos de elaboração das leis urbanísticas, tornando-as inócuas e obsoletas rapidamente. Inclusive, apontou o problema de "muitas administrações municipais em relação ao Código de Posturas e o zoneamento, argumentando que estas leis 
seriam insuficientes para respaldar o direcionamento das questões urbanísticas e do crescimento urbano."(1959 apud LEONELLI, 2010, p. 100), Afinal, o papel desempenhado pelas administrações municipais, as limitações das legislações vigentes na época e a explosão de loteamentos funcionavam majoritariamente para alimentar o mercado imobiliário, colonizando a cidade com "empreendimentos prematuros e loteamentos arbitrários", isto é, sem quaisquer cuidado com diretrizes de integração com o tecido urbano existente.:

(...) legislação urbanística federal vigente não impedia que estes empreendimentos fossem aprovados e vendidos mesmo sem terem sido implementados, contribuindo para uma valorização artificial. Por outro lado, os governos municipais incentivavam a expansão de lotes e do perímetro urbano para ampliarem a arrecadação de impostos, sem contabilizarem os gastos futuros com a implantação e manutenção dos novos núcleos urbanizados (MODESTO,1959, apud, LEONELLI, 2010, p. 100, grifo nosso),

Por fim, como bem define Santoro (2012, p. 73), de maneira geral a normatização sobre a ocupação do território, entre 1930 e 1950, serviu como sustentáculo político da elite econômica brasileira que, apesar de apoiar e precisar da urbanização (industrialização), não queria se ver livre dos seus privilégios, nem abrir mão dos lucros exorbitantes que esse processo proporcionava. Isto é, a legislação urbanística se apoiou em duas funções:

reserva de terras e manutenção do patrimônio das classes mais altas em áreas centrais, através de zoneamento de controle; e a regularização e anistia de parcelamentos mais centrais, acompanhada de regulamentação dos novos. Inicialmente, nos anos 1930, o poder público dedica-se caso-a-caso à regularização de arruamentos; posteriormente faz uma série de anistias (Passos, 1983); e chegando nos anos 1950, cancela a possibilidade de registrar ruas particulares. No mesmo período, o poder público irá regulamentar novos parcelamentos, apenas no que tange as responsabilidades dos arruamentos e a infraestrutura necessária (inclui estrutura de água potável, etc).

\subsubsection{O Governo JK e ascensão das empreiteiras}

Fica evidente, até aqui, a proximidade entre o poder público, as classes dominantes e as empreiteiras privadas no que tange às decisões categóricas dos caminhos da urbanização brasileira. Raquel Rolnik (2015) chama a atenção para o fato de que muito embora Vargas já tenha favorecido construtoras nacionais desde os anos 1930, o Estado ainda detinha certa autonomia para atuar tanto como contratador quanto realizador de obras públicas. O Plano Nacional de Viação, de 1945, transformou o Departamento Nacional de Estradas e Rodagem (DNER) em autarquia e passa a ser "o primeiro ponto de articulação entre firmas de engenharia nacionais recém-fundadas e o governo" (ROLNIK, 2015, p. 343). O objetivo era justamente criar um parque industrial de construção civil nacional, sem a necessidade de depender de empresas estrangeiras (e, obviamente, agradar investidores da burguesia nacional em troca de apoio político). 
A partir da década de 1950, com Juscelino Kubitschek, o Estado se consolida como contratante do mercado privado (principalmente das empresas "apadrinhadas" politicamente), utilizando recursos oriundos de fundos públicos. As grandes obras públicas dos "50 anos em 5" demandavam um volume de atividades que o Estado não conseguiria prover, consolidando o setor privado como executor desses projetos.

"Durante o governo JK, especialmente a partir da construção de Brasília,
ganharam espaço as empreiteiras mineiras. É nesse período-democrático- que as
conexões entre as empreiteiras e os partidos políticos são estabelecidas mais
claramente: Na alocação de cargos e funções do aparelho do Estado entre os
integrantes da aliança que elegeu JK, coube a indicação da diretoria do DNER à
cúpula do PSD, à qual justamente se encontravam politicamente ligados a
empreiteiros, em especial os empreiteiros de Minas Gerais. Questionados sobre
as razões que haviam levado JK a presenteá-los com a diretoria do DNER, os
empreiteiros mineiros são claros em afirmar a relação de dependência mútua
existente entre eles e o governo. Nesta relação, as empreiteiras precisavam das
obras rodoviárias do programa de metas para crescerem e JK precisava articular
uma base de apoio político, atendendo aos interesses de um grupo de empresários
mineiros que haviam contribuído substancialmente para sua campanha à
Presidência da República" (CAMARGOS, 1993, apud, ROLNIK, 2015, p. 343-
344)

Em contrapartida, na mesma década começa a surgir movimentação pela criação de uma nova lei de parcelamento com o intuito de sanar da expansão urbana desordenada, tendo em vista as diversas falhas (intencionais?) do decreto 38 de 1937 nesse propósito. Entretanto, em 1955, o projeto de lei ofre veto presidencial e revela que o governo federal optou por não interferir na política urbana, seja para dar "celeridade" aos projetos de urbanização, apesar dos problemas, seja para continuar favorecendo a iniciativa privada com a desregulação. (LEONELLI,2010). Ainda, ao preferir não determinar a regulação urbanística, o governo também demonstra optar "que as vias dos loteamentos não passassem para o domínio público para que os municípios não se responsabilizassem pela implantação das redes de abastecimento de água, coleta de esgoto.” (LEONELLI, 2010, p. 87). Observa-se, portanto, uma postura de esquiva do poder público em relação à tarefa de planejar e gerir o espaço da cidade, abrindo ainda mais espaço para que a inciativa privada tomasse conta dela, como bem interessasse. Isso, obviamente, gerou diversos questionamentos sobre domínio público e competência dos entes envolvidos durante a expansão urbana (tema que será aprofundado mais adiante).

Em 1960, quando a capital federal foi transferida do Rio de Janeiro para Brasília, houve a interiorização desse novo modelo de sistema urbano no país, impulsionado pelo processo de urbanização em curso. (LEONELLI, 2010). Ocorreram alterações territoriais em nível nacional e implicações sócio-espaciais intra-urbanas, como ilustra Faria (1991):

[...] o processo de urbanização que vem ocorrendo no Brasil nos últimos trinta anos apresenta [...] uma dupla característica. Por um lado, concentra grandes 
contingentes populacionais - em termos de tamanho absoluto - em um número reduzido de área metropolitanas e grandes cidades [...]; por outro, alimenta o crescimento da população urbana de um grande número - e crescente - de cidades de diferentes tamanhos que se integram num complexo padrão de divisão territorial de trabalho social tanto entre o campo e a cidade como entre as cidades [...]. Neste sistema, em trinta anos, surgiram 386 novas cidades de mais de 20 mil habitantes (FARIA, 1991, p. 103, apud LEONELLI, 2010, p. 77).

Santos (1994, p. 9, apud LEONELLI, 2010, p. 77) argumenta que além das cidades já bastante poderosas na hierarquia urbana nacional, começam a se desenvolver as cidades intermediárias, numa sistema de rede com demais cidades menores, "todas, porém, adotando um modelo geográfico de crescimento espraiado, com um tamanho desmensurado, que é a causa e é efeito da especulação”. É justamente nesse momento que a cidade de Ribeirão Preto começa a se integrar com algumas dinâmicas nacionais de ocupação segregada do espaço, bem como dá indícios do nascimento das relações locais de poder entre construtoras e gestão pública.

\subsection{Ditadura Militar (1964-1985)}

\subsubsection{Contexto social, político e econômico}

Tão logo chega à presidência da República, João Goulart movimenta a política nacional em 1961 com seus projetos de reforma do Estado brasileiro (as chamadas "reformas de base"). As propostas envolviam a reestruturação de uma ampla série de setores, como fiscal, bancário, administrativo, universitário e, principalmente, fundiário (rural e urbano). Destaca-se, também, a movimentação pelo sufrágio universal, incluindo analfabetos a as patentes de menor hierarquia nas forças armadas, como marinheiros e sargentos. No geral, o projeto de nação apresentado por Goulart enfatizava a necessidade de soberania popular sobre os rumos da política e da econômica - "defendia-se medidas nacionalistas prevendo uma intervenção mais ampla do Estado na vida econômica e um maior controle dos investimentos estrangeiros no país, mediante a regulamentação das remessas de lucros para o exterior." (FERREIRA, 2017)

Diversos grupos sociais e militantes políticos da causa fundiária surgiram durante o processo de construção da nação brasileira, ao longo do século XX. A base ideológica de Goulart e o momento político do país contribuíram para que essas demandas fossem levadas até o núcleo da administração pública, como nunca tivera sido feito. Vale lembrar que o contexto internacional da Guerra Fria influenciou diversos governos do mundo, sob sistema capitalista, a adotar posturas mais coletivistas e de bem-estar social, afinal, havia grande 
disputa por modelos hegemônicos de mundo. Em um país com tantas desigualdades crônicas, como o Brasil, o fortalecimento de uma visão alternativa de desenvolvimento deu grande força para movimentos populares, geralmente apartados das decisões políticas do país, culminando na eleição de Jango. Em discurso por ocasião do encerramento do $1^{\circ}$ Congresso Camponês realizado em Belo Horizonte em novembro de 1961, João Goulart, afirmou que não só era premente a realização da reforma agrária, como também declarou a impossibilidade de sua efetivação sem a mudança da Constituição brasileira que exigia indenização prévia em dinheiro para as terras desapropriadas. (FERREIRA, 2017).

No que diz respeito à reforma urbana vislumbrada por Goulart, as propostas focariam no desenvolvimento de programas habitacionais, em que os inquilinos pudessem comprar as residências por eles já alugadas. Com ajuda do governo central, a aquisição da moradia própria também poderia ser feita mediante compra de títulos da dívida pública, o que tentaria solucionar tanto o problema do déficit habitacional quanto das finanças do Estado, este cada vez mais comprometido em gastos habitacionais em função do êxodo rural provocado pela industrialização.

As propostas de reformas desagradaram os setores mais conservadores do cenário político, principalmente no que envolvia as alterações na política fundiária da constituição de 1946. Muito embora Goulart tenha planejado fortalecer a questão com a criação do Conselho Nacional de Reforma Agrária, em 1962, a iniciativa não teve nenhum resultado prático e durante todo o governo parlamentarista a agenda das reformas não avançou. (SAULE JR., 2007) O restabelecimento do presidencialismo em 1963 ampliou os poderes de Goulart, agravando a tensão política vez que o mesmo avançava no debate político sobre a questão fundiária, inclusive apresentando já no primeiro semestre de 1963 um anteprojeto de reforma agrária que previa a desapropriação de terras com título da dívida pública, ensejando alteração constitucional.

No âmbito urbano, o então presidente encaminhou simultaneamente um projeto de emenda constitucional que propunha o pagamento da indenização de imóveis urbanos desapropriados por interesse social com títulos da dívida pública. A reprovação dessas propostas no congresso inflamou ainda mais os movimentos políticos de esquerda, colocando centenas nas ruas em apoio a Goulart. (SAULE JR., 2009) Até setores mais conservadores, como o exército, se mobilizaram contra a resistência do congresso e em setembro de 1963 eclode a Revolta dos Sargentos, reivindicando o direito de que graduados 
das forças armadas (sargentos, suboficiais e cabos) exercessem mandato parlamentar em nível municipal, estadual ou federal (SAULE JR., 2007).

Apesar do apoio popular João Goulart começa o ano de 1964 virtualmente isolado no governo, sem conseguir negociar sua agenda com o Partido Social Democrático (PSD) e com as forças mais conservadoras. Diante desse cenário a ofensiva do presidente foi tentar agregar apoio mais amplo da sociedade e tentar neutralizar os argumentos contrários do congresso, que questionavam sua legitimidade. A empreitada política focou no discurso pelo operariado, exaltando as reformas de base, convocando os principais grupos de esquerda para agir em campo e organizar grandes comícios. (FERREIRA, 2017) Entretanto, como se sabe, no mesmo ano o Brasil sofre um golpe civil-militar, com apoio dos Estados Unidos ${ }^{16}$, e João Goulart é exilado no Uruguai até 1976, quando retorna para ser sepultado.

Logo após tomarem o poder os militares instituíram o "Comando Supremo da Revolução" e reprimiram violentamente os reformistas à esquerda, como por exemplo o CGT, a União Nacional dos Estudantes (UNE), as Ligas Camponesas e grupos católicos como a Juventude Universitária Católica (JUC) e a Ação Popular (AP). Milhares de pessoas foram presas de modo irregular, e a ocorrência de casos de tortura foi comum, especialmente no Nordeste onde o líder comunista Gregório Bezerra fora arrastado pelas ruas de Recife completamente amarrado. Diante desse cenário de total repressão os projetos de reforma fundiária e urbana são adiados novamente. (CASTRO, C. 2017)

O golpe militar interrompeu um ciclo virtuoso de debates sobre as cidades. Inclusive, no ano anterior (1963) fora realizado um grande congresso de reforma urbana promovido pelo Instituto dos Arquitetos do Brasil. De acordo com Saule Junior (2006) a temática só seria retomada com maior intensidade nas décadas de 1970 e 1980, quando já se começa a discutir o "embrião" do Estatuto da Cidade. As conquistas dos movimentos sociais e dos profissionais da área foi se dando de maneira lenta e gradual, conforme o regime militar permitia alguma abertura de participação. Apesar da repressão e a pouca permeabilidade política do governo os movimentos sociais aos poucos ganhavam mais

\footnotetext{
16 A Operação Brother Sam foi desencadeada pelo governo dos Estados Unidos, sob a ordem de apoiar o golpe de 1964 caso houvesse algum imprevisto ou reação por parte dos militares que apoiavam João Goulart (Jango), consistindo de toda a força militar da Frota do Caribe, liderada por um porta-aviões da classe Forrestal da Marinha dos Estados Unidos e outro de menor porte, além de todas as belonaves de apoio requeridas a uma invasão rápida do Brasil pelas forças armadas americanas.
} 
visibilidade e relevância no cenário nacional, através de trabalhos de base junto das periferias e de um discurso marcado pela autonomia. Importantes instituições como a Igreja Católica também contribuíram para o avanço das discussões e a resistência da causa urbana país, principalmente após o lançamento da "Ação Pastoral e o Solo Urbano", em que se defendia a função social da propriedade (e se tornou referência para a inclusão desse princípio em marcos legais posteriores). (UZZO et. Al., 2006)

Entre 1940 e 1991 a população urbana passou de $31,2 \%$ a $75 \%$ do total da população nacional, sendo que só durante o período militar a mudança foi de 44, $67 \%$ para $75,59 \%$ (aproximadamente).

Tabela 2 - Taxa de urbanização no Brasil (1940 - 1991)

\begin{tabular}{|c|c|}
\hline Periodo & Taxa de urbanizaçäo \\
\hline 1940 & 31,24 \\
\hline 1950 & 36,16 \\
\hline 1960 & 44,67 \\
\hline 1970 & 55,92 \\
\hline 1980 & 67,59 \\
\hline 1991 & 75,59 \\
\hline
\end{tabular}

Fonte: IBGE, Censo demográfico 1940-2010. Até 1970 dados extraídos de: Estatísticas do século XX. Rio de Janeiro: IBGE, 2007 no Anuário Estatístico do Brasil, 1981, vol. 42, 1979.

Após décadas de industrialização e intenso êxodo rural as cidades brasileiras se encontravam abarrotadas e sem infraestrutura adequada. Soma-se a isso a alta concentração de renda e a política urbana centrada no lucro de empreiteiras e investidores, o que agravava a situação para as pessoas mais pobres e as empurrava cada vez mais para as periferias precarizadas. Em pesquisa recente realizada pelo IPEA e pela UNB foi revelado que a acumulação de renda no topo dos $1 \%$ mais ricos deu um salto nos primeiros anos de regime militar. Os novos números desmistificam o milagre econômico como único responsável pelo aumento do fosso entre os mais ricos e os mais pobres. Segundo os economistas as medidas dos anos de recessão e o ajuste do começo do período, que incluíram isenções fiscais, arrocho salarial e repressão a sindicatos, foram determinantes para a reversão rápida, entre 1964 e 1968. (MEDEIROS; SOUZA, 2015, p. 128-129) 
Gráfico 1 - Desigualdade social no golpe militar de 1964

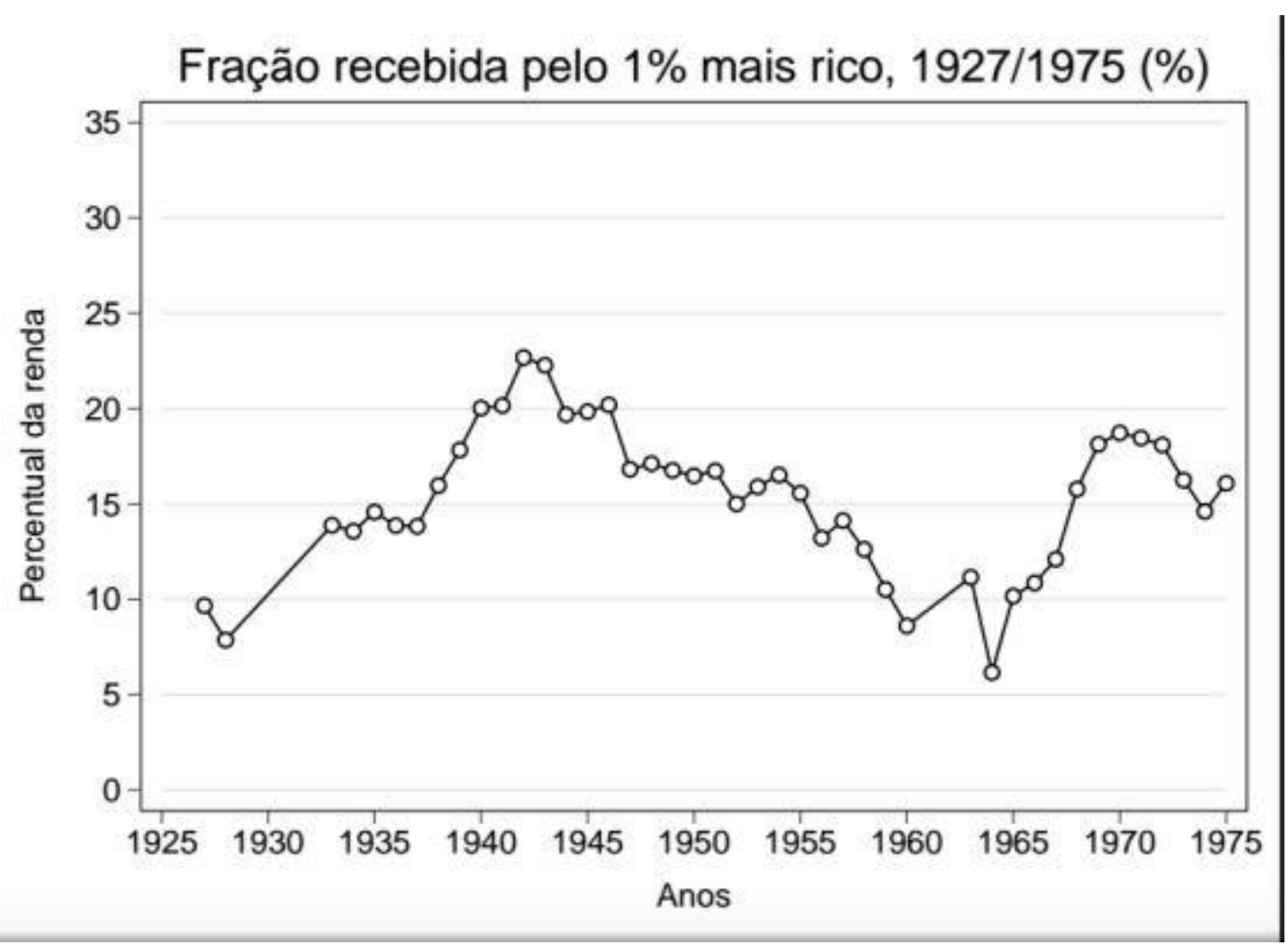

Fonte: SOUZA, P.H.G.F.; MEDEIROS, M. “Top Income Shares and Inequality in Brazil” in Sociologies in Dialogue. Revista da Sociedade Brasileira de Sociologia (ISSN 2447-2670) SID, Porto Alegre, v. 1, n. 1, p. 119-132, jul.-dez. 2015

A análise da desigualdade social é importante para entender as dinâmicas de organização urbana, tanto porque podem provocar o inchaço das periferias empobrecidas como porque aumentam as chances de surgir bairros exclusivos de alta renda (condomínios). Partindo desse pressuposto e com o que se vê no gráfico, nota-se que o país vinha numa caminhada de superação da concentração de renda e, quando as políticas urbanas de Goulart finalmente começaram a ser pensadas como problema social, é implantada a ditadura militar com pensamento econômico conservador, revertendo todo o processo alcançado. (MACARINI, 2000, p. 2-3) :

Para os tecnocratas conservadores a ditadura representou uma oportunidade extraordinária para a aplicação de sua orientação pretensamente racional e eficiente à política econômica, uma vez suprimidas de um golpe quaisquer 
propostas alternativas enraizadas no nacional-desenvolvimentismo e as possibilidades de mobilização popular em seu apoio. A face austera exibida pelo regime durante o governo Castello Branco por um momento descortinou um horizonte favorável à implementação duradoura desse enfoque para a política econômica, estendendo-se pelo tempo que fosse necessário à obtenção de seus frutos. Contudo, como logo se viu, mesmo os ortodoxos defensores da austeridade, tinham o seu apoio pelo regime e pelo empresariado condicionado ao cumprimento de promessas definidas ainda em 1964: uma redução da inflação para $10 \%$ a.a. e a retomada do crescimento a taxas ao redor de $6 \%$ a.a. quando do término do governo Castello Branco. A restauração da lucratividade do capital, beneficiando democraticamente suas várias frações, representava o limite de tolerância para com aquela política econômica (MACARINI, 2000, p. 2-5)

\subsubsection{A administração Municipal na Constituição Federal de 1967}

A Constituição de 1967 foi a sexta do Brasil independente e a quinta enquanto República. A constituinte tinha a intenção de institucionalizar e legalizar o regime militar, até então sob a constituição de 1946. O poder autoritário dos militares visava a aumentar o controle do Poder Executivo sobre o Legislativo e Judiciário e criando desta forma, uma hierarquia constitucional centralizadora. As emendas constitucionais que eram atribuições do Poder Legislativo, com o aval do Poder Executivo e Judiciário, passaram a ser iniciativas únicas e exclusivas dos que exerciam o Poder Executivo, ficando os demais relevados a meros espectadores das aprovações dos pacotes, como seriam posteriormente nominadas as emendas e legislações baixadas pelo Presidente da República.

Obviamente a centralização de poder teve grandes consequências para a administração das cidades, que até então vinham gradualmente conquistando certa autonomia durante o período democrático. $\mathrm{O}$ art. 16, II, $\S 1^{\circ}$ da carta magna de 67 determinava que os prefeitos das capitais dos Estados e dos municípios considerados estancias hidrominerais teriam seus prefeitos nomeados diretamente pelo governador, passíveis de aprovação da Assembléia Legislativa de cada unidade federativa. Também, os Prefeitos dos Municípios declarados de interesse da segurança nacional seriam nomeados pelo governador do estado em questão e aprovados pelo presidente da república. Sendo assim, a gestão dos problemas locais em muitas das principais cidades do país ficou comprometida vez que não mais se tinha mais canal de participação popular.

Art. 16 ,II $-\S 1^{\circ}$ - Serão nomeados pelo Governador, com prévia aprovação:

a) da Assembléia Legislativa, os Prefeitos das Capitais dos Estados e dos Municípios considerados estâncias hidrominerais em lei estadual; 
b) do Presidente da República, os Prefeitos dos Municípios declarados de interesse da segurança nacional, por lei de iniciativa do Poder Executivo. (Vide Lei $\mathrm{n}^{\circ} 5.449$, de 1968)

Além disso, o $\S 2^{\circ}$ do mesmo artigo determina que só serão remunerados os Vereadores das Capitais e dos Municípios de população superior a trezentos mil habitantes (dentro dos limites e critérios fixados em lei). Ainda que os altos salários de vereados possam, de fato, subverter o propósito da representação política local, o contrário também pode ser nocivo vez que limita a participação de pessoas com baixa renda nas decisões. No país em que grande parte das pessoas tem jornadas extra de trabalho, a limitação do salário de vereador poderia selecionar representantes mais elitizados, comprometendo o acesso das camadas mais populares às decisões sobre a cidade.

Vale destacar que em 1969 a constituição é emendada (EC 01 de 1969) e seu texto normativo passa a considerar a função social como limitação ao direito de propriedade. Entretanto, ainda que esse dispositivo recaísse sobre toda propriedade sob jurisdição nacional não havia normas infraconstitucionais que regulassem sua aplicação prática. Sendo assim, sua eficácia ficou comprometida, tendo um papel meramente político "para inglês ver”. (MOREIRA, 2014, p. 29)

\subsubsection{A política habitacional e a influência na organização territorial urbana}

No mesmo ano em que ocorre o golpe de Estado, é instituído o PLANHAB (Plano Nacional de Habitação). Essa política foi bastante emblemática da nova fase de intensas regulações e planos gerais centralizadores, características do governo militar. De acordo com Paula Santoro (2012, p.75) o período de governo federal também foi acompanhado pela construção de importantes marcos que regulamentaram a política urbana no território brasileiro, como Código Tributário Nacional (Lei no 5.172/ 1966), o Código Florestal (Lei Federal o o n 4.771/1965), a Lei Federal de Parcelamento do Solo (Lei Federal n 6.766/1979) e, no âmbito rural, o Estatuto da Terra, Lei Federal no 4.504/64. Destaca-se a Lei 4.591 de 1964, conhecida como Lei das Incorporações Imobiliárias, considerada também fundamental para a estruturação do mercado Imobiliário, regulamentando a constituição de condomínios, forma que já começava a ser cada vez mais utilizada na ocupação dos espaços urbanos. (ROYER, 2013, p.51).

Muito embora todos esses marcos sejam importantes até hoje, o maior impacto do governo militar no âmbito das cidades deu-se a partir da estruturação de uma política de 
desenvolvimento urbano estruturada. A intenção era formular uma política urbana atrelada a um projeto nacional de integração entre as regiões vez que havia grande desigualdade entre elas. Dessa forma, o governo planejava criar uma extensa rede urbana de apoio ao processo produtivo em favor do empresariado nacional, reforçado um modelo de desenvolvimento ainda direcionada à elite econômica do país. (SANTORO, 2012)

A execução da política habitacional seria feita com financiamento do Banco Nacional de Habitação (BNH), órgão federal que compunha o Sistema Financeiro de Habitação (SFH). Os recursos empregados nessas atividades foram captados através do recém-criado Fundo de Garantia por Tempo de Serviço (FGTS) e de letras imobiliárias. A intenção era justamente proporcionar linhas de crédito de curto prazo a construtoras e de longo prazo para compradores de moradias, sem contar o papel que o programa teve na implantação de projetos de infraestrutura urbana. (SANTORO, 2012). O desempenho do FGTS ao longo do período de funcionamento do $\mathrm{BNH}$ assegurou, até 1980, excelentes resultados quantitativos, demonstrando que essa fonte de recursos era de crucial importância tanto do ponto de vista do custo de captação do recurso para a execução de política habitacional para renda média e média baixa, quanto do fomento à indústria da construção civil (ROYER, 2012). Nesse sentido a pesquisadora Luciana Royer elucida:

Foi de fato a constituição de um fundo parafiscal como o FGTS, por meio da lei 5.107, de 13 de setembro de 1966 , que deu outro impulso aos recursos antes restritos com os quais operava o Banco. O FGTS é um fundo financeiro formado pela contribuição mensal de empregadores aos seus empregados mediante depósito de $8 \%$ das remunerações em conta vinculada7, de natureza privada e sob gestão pública, conformando uma poupança compulsória do trabalhador que o empregador recolhe na fonte. A magnitude dos recursos do FGTS alçou o BNH à condição de segundo estabelecimento bancário do país de sua criação até o início dos anos 70 por conta da aplicação e liquidez de seus recursos (ROYER, 2009, p. 50)

Como se percebe, a execução dos projetos urbanos era completamente dependente e sujeita às vontades do governo federal. Nesse sentido, haviam duas formas de se conseguir financiamento para programas habitacionais: a primeira seria através da Financiadora de Estudos e Projetos - Finep e a segunda pelo Fiplan, do BNH, voltado ao planejamento das cidades, articulado com o Serviço Federal da Habitação e do Urbanismo SERFHAU , envolvendo a elaboração de planos diretores. (SANTORO, 2012, p. 84). Para conseguir repasse de verba federal nessas atividades era necessário que a prefeitura tivesse elaborado um plano urbanístico (Planos Diretores de Desenvolvimento Integrado-PDDIs) 
e então submetido ao SERFHAU. A literatura mostra que esse tipo de planejamento imposto de cima para baixo e exigido "para cumprir obrigação" não surtiram o efeito esperado, vez que geralmente eram feitos por consultorias externas à gestão da cidade. "Pouco tempo durou o SERFHAU (1964-1974) e com seu fechamento diminuiu o interesse pelos planos e o próprio programa Fiplan desinteressou-se de financiar planos". (SANTORO, 2012, p. 84)

Villaça (2004) destaca que os planos diretores do período militar não serviam para orientar obras públicas, cuja viabilização se dava através de planos setoriais. Também, não legitimavam as ações das prefeituras, pois não utilizavam os planos como orientadores de suas ações; vários deles sequer foram aprovados pelas Câmaras, que não os reconhecia como sendo política do município. (Villaça, 2004, p.190 apud SANTORO, 2012). "Dessa forma, o planejamento urbano do período militar se caracterizava por ser eminentemente técnico, desprovido de carga política, reduzindo seus resultados a amplos diagnósticos municipais" (SANTORO, 2012, p. 84)

Vale notar que as normas, tecnicistas ou não, pareciam oferecer ampla liberdade à atuação do mercado imobiliário, sem oferecer qualquer tipo de resistência às mudanças de uso rural para urbano. Inclusive, em alguns casos, foram propositalmente utilizadas para esse objetivo. O BNH era um dos responsáveis pela compra de grandes porções de terra fora da zona urbana (mais barata) esperando com isso recuperar o investimento quando da alteração do perímetro urbano e a valorização da propriedade (isso em tese barateava o preço final das moradias e ainda fazia render o dinheiro dos fundos de pensão utilizados no investimento) (ROYER, 2013). Entretanto, ainda que tais proposições tenham de fato utilidade, a política contribuiu para a ampliação sem critérios do perímetro urbano, arrastando consigo muitos "efeitos colaterais" como o espraiamento da cidade, a disseminação de vazios urbanos e a especulação imobiliária. É o que elucida Paula Santoro (2012, p. 137-138):

Ampliar este mercado imobiliário envolve, portanto disponibilizar terras, através de ações públicas como aumento do perímetro urbanizável; manter as políticas e planos que, por muito tempo, evitaram tratar do tema da expansão urbana ou regular o crescimento urbano horizontal; liberar áreas que eram objeto de restrições à ocupação ou adensamento, como é o caso de áreas com restrições ambientais. Neste processo de transição de uso rural para urbano há uma grande valorização da terra que beneficia proprietários, que mantém altas rentabilidades e a possibilidade de especular com a terra; geralmente onerando a gestão pública que tem que ampliar serviços e oferta de equipamentos sociais, nem sempre produzindo espaços justos, com mesclas sociais e com qualidade urbanoambiental. E, principalmente, raramente está voltado para atender as necessidades urbanas e habitacionais da população, ou mesmo processos de crescimento populacional (Santoro \& Bonduki, 2009). Mesmo reconhecendo o 
ônus público da opção de crescer de forma dispersa, as políticas de flexibilização têm acontecido, sem medir as conseqüências para o urbano

A atuação da política habitacional induziu, em muitos casos, à formação de um estoque de terras com o intuito de produzir a habitação de interesse social (buscava-se, a longo prazo, ajudar a regular o mercado e os preços da terra). Havia o início de uma conscientização da sociedade civil (principalmente na academia) de que a política colaborava com a especulação dos terrenos e demandava uma maior regulação das transformações de uso (como alteração do perímetro urbano).O poder especulativo dessa estratégia obviamente foi percebido por diversos atores envolvidos no loteamento e no parcelamento do solo urbano, reforçando o poder privatizante das leis urbanísticas. A execução de boa parte da política habitacional foi feita sem o planejamento das áreas de expansão urbana, com conjuntos habitacionais dissociados de infraestrutura urbana, serviços e equipamentos públicos (principalmente sistemas de transporte), e com projetos urbanos ruins.

Sendo assim, Luciana Royer (2013, p.14) salienta que muito embora todo esse aparato institucional criado no governo militar tenha sido exitoso em produzir moradia popular, é inegável o seu caráter concentrador de renda já que no final das contas as unidades subsidiadas ocupavam parcelas consideráveis do território e eram destinadas a segmentos médios e altos da população. (garantindo a apropriação de parte dos recursos pelo setor empresarial ligado à construção civil e pelos grupos rentistas)

\subsubsection{O Decreto-lei $271 / 1967$}

Em 1967 é instituído pela presidência da República o Decreto Lei 271, cujo conteúdo dispõe sobre loteamento urbano, responsabilidade do loteador, concessão de uso e espaço aéreo e etc. $\mathrm{O}$ intuito era complementar os aspectos civis relativos ao processo de loteamento e tentar regular a atividade de modo abrangente em todo o território (visto que a matéria ainda se baseada no problemático decreto 58/1937). Em 1964 houve iniciativa do Instituto dos Arquitetos do Brasil no sentido de fomentar uma nova lei federal sobre parcelamento do solo, visto que os mesmos problemas relatados na década de 30 ainda atingiam as cidades e se agravavam conforme o êxodo rural se intensificava. Para tanto, convidaram os juristas para elaborar um projeto de lei (LEONELLI, 2010, p. 87)

De acordo com os juristas, era premente a necessidade de regulação dessa atividade não só sob a visão do Direito Civil, exclusivamente discorrendo sobre compra e 
venda da propriedade, mas sob o olhar do direito urbanístico, adequado à multidisciplinariedade das relações envolvidas, como por exemplo a questão dos bens públicos urbanos. Ainda, salientaram o quanto a disseminação sem controle dos loteamentos se dava com maior intensidade nas cidades do interior, que dificilmente possuíam lei sobre loteamento urbano. (...)"tinha um dono de terra aqui na periferia e fazia o loteamento do jeito que ele queria. Não tinha nenhuma norma para ele, por exemplo, para deixar uma praça pública, para ter um lugar de lazer, não tinha nada, lote mínimo, não havia obrigatoriedade de nada". (AZEVEDO, em entrevista concedida a autora em 01/04/2010, apud LEONELLI, 2010, p. 88).

Meirelles (2010) argumentou que o aspecto urbanístico estaria circunscrito no direito administrativo municipal, sendo descabida a regulação pontual e isolada tratando dos aspectos contratuais da transmissão da propriedade urbana .Em seu livro "Direito Administrativo Brasileiro " - defendia a urgência para que os municípios elaborassem suas leis sobre loteamentos, definindo normas urbanísticas e sanitárias, estipulando percentuais mínimos para áreas públicas, dimensões de ruas e infraestrutura como energia elétrica, água, esgoto e transporte coletivo.

Entretanto, do projeto elaborado por Meirelles e Azevedo foram subtraídos vários artigos relativos a esses aspectos urbanísticos, o que desconfigurou o texto original. Foi aprovado parte da lei, que gerou o Decreto-Lei Federal 271/1967, mantendo desregulada a colonização das terras circundantes aos centros urbanos. A expansão urbana manteve-se atrelada à logica de lucratividade em detrimento da urbanidade.

Destaca-se que o artigo $3^{\circ}$ desse dispositivo determina aplicação "aos loteamentos a lei 4.591 de 1964, equiparando-se o loteador ao incorporador, os compradores de lote aos condôminos e as obras de infra-estrutura à construção da edificação" (BRASIL, 1967). A Lei $n^{\circ}$. 4.591/64 dispõe sobre o condomínio em edificações e as incorporações imobiliárias, não tratando de loteamentos, e sim do regime de propriedade de condomínios verticais. Entretanto, Leonelli (2010, p. 126) destaca que o referido artigo do DL 271 permitiu interpretar o loteador como incorporador e induziu ao entendimento de que os condomínios horizontais, conhecidos loteamentos fechados, pudessem ser regidos pela lei de condomínios em edificações e não pelas leis municipais de loteamento existentes. Segue portanto uma primeira grande tentativa de legalizar a ação de empresas e investidores que seguiam ganhando muito dinheiro com a expansão desregulada das cidades. 


\subsubsection{A Lei 6766/79}

De acordo com Nabil Bonduki (2007) o loteamento constituiu o modelo mais comum de expansão urbana no Brasil desde 1930. O autor ainda enfatiza que o início dos anos 60 sinalizou um aprofundamento da crise urbana e habitacional tendo em vista a maior intensidade que esses processos de urbanização e industrialização aconteciam. Nesse contexto, o período militar foi marcado por dois grandes eventos nacionais (civis) que agregaram força política e conhecimento sobre os problemas ${ }^{17}$ desencadeados pela transformação. O primeiro foi o Seminário sobre Uso do Solo e Loteamento Urbano, realizado em Salvador em 1969, promovido pelo CEPAM $^{18}$, com caráter eminentemente técnico (sobretudo em relação aos loteamentos). Criado em 1967 como órgão estatal, o CEPAM participava como entidade de assessoramento técnico dos municípios paulistas justamente por isso tinha bastante contato com os principais problemas urbanísticos da época (LEONELLI, 2010, p. 114) No encontro foi debatido um anteprojeto de lei de parcelamento e, posteriormente, encaminhado para apreciação ao Executivo Federal.

O segundo evento de destaque foi o Simpósio "O Homem e a Cidade", proposto pela Fundação Milton Campos em 1975, com caráter mais político e menos técnico que o outro mas com igual anseio por uma lei federal que abarcasse todos os aspectos necessários à reformulação da política urbana. Ainda que o governo militar tenha reprimido duramente os movimentos sociais em prol da reforma urbana, a atuação dessas instituições garantiu que pelo menos as discussões se mantivessem durante o período. O CEPAM foi importante órgão de representatividade nesse sentido, assim como universidades públicas, representantes do SERFHAU, IAB de Pernambuco e IPEA - Instituto de Pesquisa Econômica Aplicada também se fizeram presentes. (LEONELLI, 2010, p.116). Enquanto

\footnotetext{
17 - Nelson Saule Junior, p. 20, 2008 ${ }^{17}$ : "Plano de expansão urbana como condição de extensão do perímetro urbano - "Há a necessidade de definição de zona de expansão urbana no Projeto de Lei e a inclusão da obrigatoriedade do plano de expansão urbana no Artigo 7o Deve constar da revisão da Lei Federal no 6.766/79 que os planos de expansão tornem-se obrigatórios na abertura de qualquer novo loteamento que se encontre em uma zona de expansão urbana. Nestes planos de expansão deve ser determinada, ainda, a obrigatoriedade de percentual de doação de terra para implementação de HIS. O marco regulatório do parcelamento do solo - tanto nacional como local -, com sua visão privatista (gleba a gleba) e rentista (percentuais fixos, sem relação com os diferentes sítios urbanos e situações municipais quanto à necessidade de infra-estrutura e equipamentos), tem incidido de forma negativa tanto no processo de expansão adequada das cidades quanto na disponibilização de terras para moradia. Na experiência internacional de planejamento urbano, raros são os países desenvolvidos que prescindem de um planejamento da expansão urbana, no qual já se predefinem os sistemas viários e de mobilidade básicos, assim como o dimensionamento e a localização de equipamentos, áreas verdes e áreas de lazer
}

${ }^{18}$ Centro de Estudos e Pesquisas de Administração Municipal 
o crescimento econômico do "milagre brasileiro" acontecia a posição repressiva do governo militar se sustentava. Entretanto, ao fim da década de 70 o Brasil entra novamente em crise e as pressões populares se intensificam sobre o regime. Nesse contexto, em 1979 o projeto da Lei Federal de parcelamento é aprovado, tanto em virtude dos estudos e movimentos que sustentaram o projeto desde o início quanto em função do apelo populista que a aprovação poderia ter, apaziguando os ânimos contra o governo (SANTORO, 2012)

No que tange à influência dessa lei sobre a expansão urbana, destacam-se os seguintes aspectos:

- A partir do art. $3^{\circ}$ fica limitada a possibilidade de parcelamento do solo com uso urbano somente em área urbana e de expansão urbana. Isso incumbe as prefeituras do dever de definir o perímetro urbano em lei municipal (esperando, assim, evitar o espalhamento da cidade sobre a zona rural)

- A lei não defini os critérios específicos para que uma zona possa ser considerada de expansão urbana. Dessa forma, argumenta-se que ela não garantiu que o crescimento urbano se desse por contiguidade, favorecendo a expansão "em retalhos", a gosto dos investidores imobiliários. (Leonelli, 2010, p.174)

- De acordo com Paula Santoro (2012, p.100) A aprovação da Lei induziu muitos a municípios definir seus perímetros tanto para poderem regular seu crescimento, quanto para regular usos e preços da terra, criando um "mapa" sobre onde cobrar impostos (influência tributária)

- Foi estabelecido um mínimo de áreas públicas a serem resguardadas em cada empreendimento, cumprindo assim função coletiva da cidade:

\begin{abstract}
"35\% da área total da gleba objeto do parcelamento deverá ser utilizada com áreas públicas $\left(4^{\circ}\right)$, cuja definição deve constar no projeto e memorial descritivo $\left(\right.$ art. $\left.9^{\circ}\right)$ e não deverão ser alteradas. Como se trata de uma lei federal, atribui o controle sobre onde serão estas áreas ao município que poderia, por exemplo, a partir da certidão de diretrizes de uso do solo (art. $6^{\circ}$ ) enviada ao parcelador, manifestar-se sobre alguns detalhes de projeto de interesse público, como a necessidade de reserva de espaço para vias previstas em seus planos, etc. (SANTORO, 2012, p. 102)
\end{abstract}

- A lei obriga o município a emitir diretrizes de uso do solo antes de poder aprovar o parcelamento. O que acarretaria em maior planejamento do território e determinação dos zoneamentos 
- A lei elencou uma série de punições a loteadores irregulares. Dentre elas, destacase a que prevê crime contra a Administração Pública (art.50) pelo não cumprimento de suas regras e parâmetros, com previsão de coautoria de crime envolvendo loteadores, funcionários do executivo, órgãos licenciadores e do registro de imóveis.

Dentre todas as inovações é importante salientar que a 6766 praticamente inaugura o perímetro urbano como política de regulação da organização periurbana, e é inegável os avanços que ela trouxe para a área, pouco discutida no ordenamento. Entretanto, existem muitas críticas sobre a eficácia dos instrumentos na prática. Paula Santoro (2012), por exemplo, argumenta que muitos técnicos da prefeitura terminam aprovando os projetos enviados sem respeitar todos os critérios, muitas vezes porque a cidade não estabeleceu diretrizes de expansão viárias ou de zoneamento. Isto é, a lei demanda uma quantidade bastante alta de fiscalização para que possa surtir efeito. E, no período de crise que o Estado brasileiro se encontrava foi bastante difícil encaixar essas tarefas no orçamento.

Além disso, a dependência de repasse de recursos pelo governo federal deixou muitos municípios reféns do setor privado na execução de obras, fazendo com que os projeto irregulares fossem (e são) aprovados com vista grossa da prefeitura. É obvio que não se pode excluir a culpa das administrações públicos por serem coniventes com essa prática. Entretanto, o enfraquecimento orçamentário das gestões locais, somados ao crescente poder da indústria de construção civil criou ambiente ideal para a existência de relações políticas de favor, tradicionalmente presentes na história como bem demonstram as investigações da polícia federal em 2016 e 2017.

Também, a pretensão fiscalizatória e punitiva demandava uma quantidade extraordinária por funcionários. Sendo assim, as determinações penais não conseguiram ser aplicadas , sendo ainda mais prejudicadas pelos lentos processos judiciais, que com frequência acabavam em prescrição.

\subsection{Nova República}

O fim da ditadura militar renovou as esperanças dos movimentos engajados na política urbana, permitindo que o aparato institucional fosse disputado por interesses antes inacessíveis à maioria da população. A partir da abertura política do país, o Governo de José Sarney já demonstra abordagem mais preocupada com a questão urbana e cria o 
Ministério do Desenvolvimento Urbano e Meio Ambiente, pelo Decreto ${ }^{\circ} 91.145$ de 15 de março de 1985. Além da pressão de entidades ligadas à área, a medida foi justificada por conta da situação caótica das cidades brasileiras, principalmente em questões como o saneamento básico e saúde pública. Ainda, a medida considerou a especulação imobiliária como responsável por parte da crise urbana e reconheceu a necessidade de uma política habitacional e de desenvolvimento que estivessem lúcidas e ativas na solução dos problemas das cidades. De acordo com Bezzon (2008, p.131), diante desse cenário "não só o operariado, mas até setores da classe média tiveram virtualmente barrado o seu acesso a moradia própria”. (BEZZONN, 2008, p. 131)

O período trazia a promessa de que finalmente a população poderia participar das decisões políticas com maior contundência. Entretanto, ao longo dos anos ficou claro que o contexto político e econômico (nacional e internacional) não estava em consonância com essas expectativas. As profundas transformações do padrão de acumulação capitalista nas últimas décadas e a disseminação das finanças como matriz de organização da riqueza em escala mundial impuseram uma nova racionalidade ao desenho institucional das políticas públicas, tanto nos países de centro quanto nos países subdesenvolvidos.

A partir dos anos $70^{19}$, "a crise físcal do Estado, associada à reestruturação da apropriação do excedente no sistema mundial, implicou em uma inflexão substantiva na trajetória de reconhecimento de direitos e na oferta estatal de bens e serviços públicos." (ROYER, 2013, p.13) Ao tempo que a expansão financeira se consolidava e se capilarizava no sistema mundial, foi observado um padrão de falência fiscal e a insuficiência dos fundos administrados pelo Estado. Dessa forma, foi esvaziada a sustentação estatal das políticas públicas welfaristas ${ }^{20}$, deslocando para o mercado o atendimento das necessidades básicas da classe trabalhadora. O Estado se limita ao atendimento de demandas focalizadas e ao fomento das economias de mercado (inclusive, há autores que pontuam que o orçamento fiscal do Estado passa a ser direcionado também para garantir a rentabilidade de aplicações financeiras de investidores privados) (ROLNIK, 2015; ROYER, 2013, p. 14) É nesse contexto econômico mundial que a administração do governo PSDB, em 1995, começa a reforma administrativa do Estado baseando-se em princípios neoliberais,

\footnotetext{
${ }^{19}$ Período afetado pelas crises do Petróleo, com grande impacto no cenário econômico mundial.

${ }^{20}$ Palavra derivada de "Welfare State. Também conhecido como "Estado de bem-estar social" ou "Estado de providência". É um conceito de governo em que Estado tem o papel predominante na proteção e na promoção do bem estar econômico e social de seus administrados. - Giddens, A. (1998), The Third Way. The Renewal of Social Democracy. Cambridge, Polity.
} 
primando pelo conceito de“ público não estatal". Dentre as principais ideias estavam os princípios organizacionais de terceirização ou publicização, descentralização, e a gerência por resultados, o que significou a implantação de um amplo programa de privatizações, as políticas macroeconômicas de estabilização do país e os programas de desenvolvimento nacional. Tudo isso capitaneado pelo Ministério da Administração Federal e Reforma do Estado. (BEZZON, 2008, p. 133)

\subsubsection{A política urbana na Constituição de 1988}

Pela primeira vez na história do Brasil uma constituição dedica um capítulo à política urbana, uma grande conquista para os movimentos políticos que há décadas militavam em favor de reformas nessa área. As disposições se concentram nos artigos 182 e 183 da Carta Magna e tem natureza precipuamente social (em sentido amplo), com grande endosso ao princípio da função social da propriedade.

$\mathrm{O}$ art. 182 caput prescreve que a política de desenvolvimento urbano, a ser executada pelos Municípios, tem por objetivo ordenar o pleno desenvolvimento das funções sociais da cidade e garantir o bem estar de seus habitantes. Inclusive, no $\S 1^{\circ}$, o plano diretor aparece como obrigatoriedade para municípios acima de vinte mil habitantes, e consta expressamente a preocupação com a regulação da expansão urbana. Cammarosano (2014, p. 22) ressalta que muito embora as funções econômicas de fato dependam ou se beneficiem de um adequado desenvolvimento das cidades, o foco desse dispositivo é viabilizar a democratização das funções sociais da cidade em proveito de seus habitantes, possibilitando a existência de mecanismos que promovam o adequado aproveitamento do solo urbano. $\mathrm{O}$ art. 183, por sua vez, ao instituir a usucapião especial de pequenas áreas urbanas com finalidade de moradia enfatiza a preocupação como o social no sentido estrito do termo (CAMMAROSANO, 2014). Dessa forma, evidencia-se que o texto constitucional de 1988 determina que os municípios têm não apenas o direito, mas o dever de intervir em processos especulativos que resultem em valorizações excessivas da terra (e, consequentemente, numa expansão urbana capturada pela mais valia urbana) (Levy et al., 2005)

Ainda, Carlos Ari Sundfeld (2014, p. 49-50) destaca que o art. 24 inaugura o direito urbanístico como disciplina jurídica constitucional, regulador do "direito da política de desenvolvimento urbano" em três sentidos: a) como conjunto das normas que disciplinam a fixação dos objetivos da política urbana (normas da constituição); b) como conjunto de textos normativos em que estão fixados os objetivos da política urbana (os 
planos urbanísticos, por exemplo); c) como conjunto de normas em que estão previstos e regulados os instrumentos de implementação da política urbana (Estatuto da cidade, entre outros). Sendo assim, a constituição define o planejamento urbano em todas as esferas como atividade eminentemente publicística em que o Estado deve assumir postura preponderante (afinal, o urbanismo é atividade de interesse coletivo).

Existem outros dispositivos constitucionais que não fazem referência direta à organização das cidades mas afetam seu desenvolvimento, principalmente sua expansão. $\mathrm{O}$ direito à moradia, por exemplo, está expressamente inserido no art. $6^{\circ}$ e mencionado no art. $7^{\circ}$ - IV como pertinente às necessidades vitais básicas dos trabalhadores urbanos e rurais. Ainda, o art. $5^{\circ}$, que prevê direitos e garantias individuais e coletivos, determina que a moradia é asilo inviolável do indivíduo e que a propriedade deve atender à sua função social (reiterado no art. 170, III). (CAMMAROSANO, 2014, p. 24)

Ao se consolidar enquanto conteúdo constitucional a moradia digna entra para o hall de direitos sociais positivados passível de judicialização e, sendo assim, cria maior pressão para que entes da administração pública se mobilizem em desenvolver programas e políticas habitacionais. É com lastro nesses direitos que programas como Minha Casa Minha Vida foram constituídos, gerando grande impacto na forma de ocupação das cidades (tanto positiva quanto negativamente). (SAULE Jr., 1997)

De maneira geral, tanto no que diz respeito à política urbana quando habitacional, fica claro que o constituinte impôs ao legislador e ao administrador público dar densidade normativa às matérias, bem como prevê a implementação de políticas que lhes assegurem plenamente a eficácia. De acordo com Cammarosano (2014, p.25) o nosso sistema constitucional impõe políticas socialmente ativas e que, a partir da legislação infraconstitucional que se desenvolve a partir de seus preceitos fundamentais, é possível viabilizar a concretização dos direitos. Como exemplo, o autor cita que mesmo com todos os princípios gerais elencados nos artigos 182 e 183 da constituição as cidades ainda continuaram com muitos problemas:

\footnotetext{
"Instrumentos normativos tradicionais - como as leis disciplinadoras do parcelamento do solo urbano, leis de zoneamento, códigos de edificação e outras disposições de ordem urbanística, e até de preservação do meio ambiente - não tem sido suficientes para a solução de muitos dos grandes problemas que afligem as cidades, especialmente os grandes conglomerados urbanos. $\mathrm{O}$ encarecimento do solo urbano, a ocupação descontrolada e degradadora do meio ambiente, especialmente por contingentes populacionais de baixa renda, tangidos para a periferia por inúmeros fatores, a especulação imobiliária, o estoque de áreas que permanecem não utilizadas ou subutilizadas ou utilizadas de forma inadequada, como se não existisse o preceito da função social da propriedade, é situação que se apresenta em descompasso com a ordem jurídica em vigor." (CAMMAROSANO, 2002, p.26)
} 
No entanto, a perspicácia do nosso modelo constitucional permite que os regramentos específicos infraconstitucionais funcionem como uma ponte entre os princípios emanados pela Magna Carta e a realidade da vida cotidiana. Sendo assim, muito embora a constituição não "resolva" de imediato os problemas da vida urbana, ela cria estrutura para que as soluções jurídicas surjam com maior especificidade no campo infraconstitucional (ainda, permite que essas normas reguladoras tragam problemas locais e em congruência com seu tempo. Caso a constituição especificasse detalhes da política urbana em seu conteúdo correria o risco de não abarcar problemas comuns a todas as regiões do país, ou se tornar obsoleta muito rapidamente, dificultando reformas).

No que tange à autonomia, a constituição estabelece o Município como entidade estatal de terceiro grau na ordem federativa, com atribuições próprias. Isto é, a autonomia municipal não decorre de delegação do Estado-membro em que o Município se situa, mas do próprio texto constitucional. (DI SARNO, 2014, p. 64-67). No contexto da presente pesquisa, é possível observar que a partir de 1988 a política urbana localizada ganha muita força para determinar como e onde a cidade poderá crescer, vide art. 30 (BRASIL, 1988):

\footnotetext{
Art. 30. Compete aos Municípios:

I - legislar sobre assuntos de interesse local;

II - suplementar a legislação federal e a estadual no que couber;

V - organizar e prestar, diretamente ou sob regime de concessão ou permissão, os serviços públicos de interesse local, incluído o de transporte coletivo, que tem caráter essencial;

VIII - promover, no que couber, adequado ordenamento territorial, mediante planejamento e controle do uso, do parcelamento e da ocupação do solo urbano;
}

Sendo assim, Hely Lopes Meirelles (2008, p.94), conceitua os seguintes adventos constitucionais que embasam a vigente autonomia municipal em: a) poder de autoorganização (elaboração de lei orgânica própria); b) poder de autogoverno (eleição do prefeito, do vice-prefeito e dos vereadores); c) poder normativo próprio ou autolegislação (elaboração de leis municipais dentro dos limites de atuação traçados pela Constituição da República); d) poder de auto-administração (administração própria para criar, manter e prestar os serviços de interesse local, bem como legislar sobre os tributos e suas rendas - artigos 29 e 30 da CF). Há, ainda, muitas críticas quanto à dependência de repasses federais para a execução de grandes obras de infraestrutura, o que 
comprometeria a autonomia de fato dos municípios. Isso abriria espaço para que agentes privados ganhassem influência nas decisões locais a partir de parcerias e concessões com as prefeituras falidas.

\title{
2.6.2. Estatuto da Cidade - o art. 42-b e a regulação do perímetro urbano
}

Passados 18 anos desde a redação do projeto de lei de desenvolvimento urbano (PL 775 de 1983) e após 13 anos de tramitação, finalmente foi aprovada a Lei 10.257 de 10 de julho de 2001 (O Estatuto da Cidade). O dispositivo vem regulamentar os artigos 182 e 183 da Constituição Federal, cujo conteúdo carecia de especificação infraconstitucional desde 1988. Ainda que "atrasado", o diploma urbanístico significou grande vitória para as forças democratizantes como o Movimento Nacional pela Reforma Urbana, participante do Fórum Nacional pela Reforma Urbana, e contribuiu com o estabelecimento de normas de ordem pública e interesse social. Bezzon resume pontualmente o papel desempenhado pelo Estatuto (BEZZON, 2008, p.136):

\begin{abstract}
Tendo como objetivo o ordenamento territorial com base a função social da cidade e da propriedade e apresenta as diretrizes gerais focadas no: desenvolvimento sustentável, garantindo direito a cidade, a moradia, infraestrutura, saneamento, transporte, serviços públicos, trabalho, lazer, para todas as gerações; gestão democrática considerando instâncias de participação social; cooperação entre governo, iniciativa privada, demais setores da sociedade; planejamento das cidades com ação regional e ambiental; oferta de equipamentos urbanos, transporte e serviços públicos; ordenação e controle do solo; entre outras diretrizes que demonstram a intenção de controle sobre o espaço urbano, regulamentação das ações sobre ele, de forma mais flexível e justa, numa visão equilíbrio, ambiental e social, estabelecido sobre o consenso da sustentabilidade.
\end{abstract}

Ainda que todos os instrumentos de política urbana previstos no E.C. contribuam de alguma maneira com a organização do território urbano, o artigo $42 \mathrm{~b}$ se destaca por definir regras gerais de determinação do perímetro urbano, pela primeira vez no ordenamento brasileiro. Até esse momento da pesquisa é possível perceber que a alteração de uso do solo tem sido utilizada tanto para favorecer loteadores privados (seja alterando diretrizes urbanísticas sob encomenda ou anistiando irregularidades) quanto para favorecer o próprio poder público (expandindo a zona urbana mirando na arrecadação de impostos) (SANTORO, 2012).

Entretanto, a justificativa que embasou a inclusão desse dispositivo na lei não levou em consideração critérios exclusivamente econômicos, mas principalmente de segurança pública, influenciado pelos desastres naturais do ano anterior. O verão de 2011 foi marcado pelas chuvas e deslizamentos de terra que assolaram principalmente a região 
serrana do Rio de Janeiro com destaque para Nova Friburgo, Teresópolis, Petrópolis, Sumidouro, São José do Vale do Rio Preto e Bom Jardim. Os serviços governamentais contabilizaram 916 mortes $^{21}$ e em torno de 345 desaparecidos. A Secretaria de Estado da Saúde e Defesa Civil do Rio de Janeiro, reportou que 428 pessoas morreram em Nova Friburgo, 382 em Teresópolis, 71 em Petrópolis, 21 em Sumidouro, 4 em São José do Vale do Rio Preto e 1 em Bom Jardim. Já as desaparecidas foram 180 em Teresópolis, 85 em Nova Friburgo, 45 em Petrópolis e duas em Sumidouro. ${ }^{22}$.

Figura 1 - Deslizamentos na Região Serrana do Rio de Janeiro (2011)

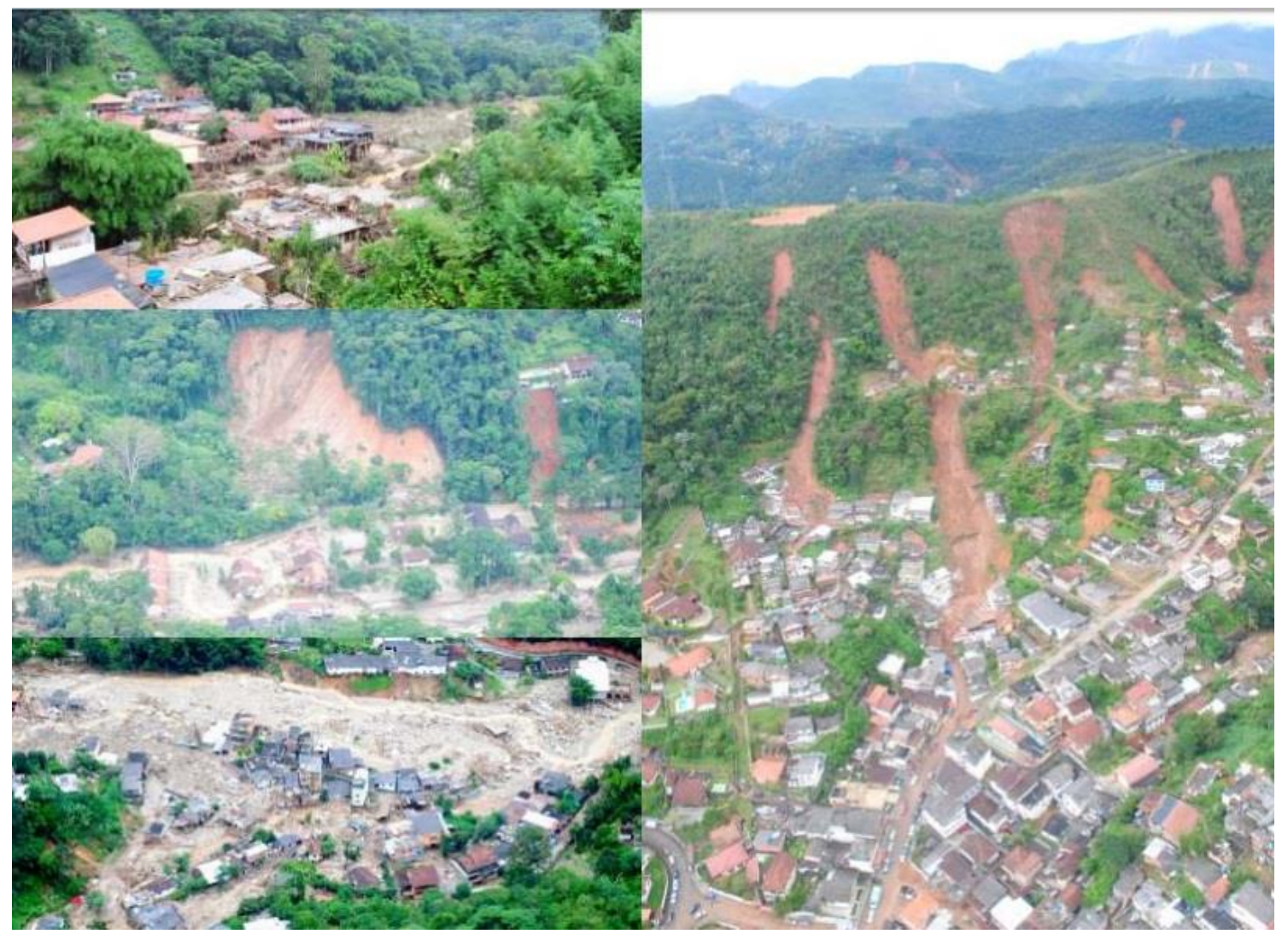

Fonte: Banco Mundial, Brasília, 2012.

Os relatórios técnicos produzidos pela defesa civil (e também por trabalhos acadêmicos) concluíram que a região de fato tinha instabilidade geológica e estava sujeita a desastres. Entretanto, as fatalidades só ocorreram por conta da permissividade, da falta

\footnotetext{
${ }^{21}$ BANCO MUNDIAL. Avaliação de Perdas e Danos: Inundações e Deslizamentos na Região Serrana do Rio de Janeiro - Janeiro de 2011. Relatório elaborado pelo Banco Mundial com apoio do Governo do Estado do Rio de Janeiro. Brasília, 2012. Disponível em http://mi.gov.br/pt/c/document_library/get_file?uuid=74dde46c-544a-4bc4-a6e1$852 \mathrm{~d} 4 \mathrm{c} 09 \mathrm{be} 06 \&$ groupId=10157 acessado em 07/2017

$22 \quad$ Ministériohttp://noticias.terra.com.br/brasil/rj-minc-anuncia-parques-fluviais-em-areas-atingidas-porchuva,93ba44fa607da310VgnCLD200000bbcceb0aRCRD.html
} 
de monitoramento e de planejamento das áreas ocupadas (por parte do poder público). As prefeituras e o Estado tinham acesso às pesquisas e estavam cientes dos riscos, entretanto, optaram por não se envolver e deixaram a população mais pobre ocupar as áreas indesejadas durante anos. Muitos criticaram os próprios moradores por se instalar nessas regiões de modo irregular "para obter vantagem". A verdade é que o urbanismo empresarial das cidades reservou as melhores áreas, mais seguras e economicamente viáveis às corporações, que as explora através de loteamentos e condomínios. Na ausência de políticas públicas que controlassem o crescimento das franjas urbanas e pensassem numa política habitacional inclusiva, as pessoas em situação de vulnerabilidade não tiveram outra escolha senão viver sob risco. (CASTILHO et al, 2012)

É justamente nesse contexto que a Lei Federal n ${ }^{\circ} 12.608$ de 2012 veio alterar o Estatuto da Cidade acrescentando o artigo 42-B, com a seguinte redação:

“Art. 42-B. Os Municípios que pretendam ampliar o seu perímetro urbano após a data de publicação desta Lei deverão elaborar projeto específico que contenha, no mínimo:

I - demarcação do novo perímetro urbano;

II - delimitação dos trechos com restrições à urbanização e dos trechos sujeitos a controle especial em função de ameaça de desastres naturais;

III - definição de diretrizes específicas e de áreas que serão utilizadas para infraestrutura, sistema viário, equipamentos e instalações públicas, urbanas e sociais;

IV - definição de parâmetros de parcelamento, uso e ocupação do solo, de modo a promover a diversidade de usos e contribuir para a geração de emprego e renda;

V - a previsão de áreas para habitação de interesse social por meio da demarcação de zonas especiais de interesse social e de outros instrumentos de política urbana, quando o uso habitacional for permitido;

VI - definição de diretrizes e instrumentos específicos para proteção ambiental e do patrimônio histórico e cultural; e

VII - definição de mecanismos para garantir a justa distribuição dos ônus e benefícios decorrentes do processo de urbanização do território de expansão urbana e a recuperação para a coletividade da valorização imobiliária resultante da ação do poder público.

$\S 1^{\text {o }}$ O projeto específico de que trata o caput deste artigo deverá ser instituído por lei municipal e atender às diretrizes do plano diretor, quando houver. 
$\S 2^{\circ}$ Q Quando o plano diretor contemplar as exigências estabelecidas no caput, o Município ficará dispensado da elaboração do projeto específico de que trata o caput deste artigo.

§ 3ำ A aprovação de projetos de parcelamento do solo no novo perímetro urbano ficará condicionada à existência do projeto específico e deverá obedecer às suas disposições."

A preocupação com segurança pública é bastante evidente no inciso II, que condiciona a criação de novas áreas de urbanização à demarcação de áreas de risco. Ainda, o parágrafo $1^{\circ}$ do mesmo artigo, revela preocupação com a definição dos perímetros urbanos em municípios sem um plano diretor aprovado. O legislador se foi cuidadoso ao tentar dar obrigatoriedade, abrangência e, ao mesmo tempo, celeridade à demarcação vez que a morosidade dos municípios em tratar das matérias poderia colocar risco a vida da população. Embora a lei seja bastante clara e específica nos critérios definidores do perímetro, as interpretações que os administradores locais fazem tende a não ser uniforme em virtude das diferentes realidades que enfrentam, sobretudo quando se considera a capacidade institucional. O que pode comprometer o seu poder regulador (TOMANIK, 2017).

Em relação ao inciso VII, é importante ressaltar que o Art. $4^{\circ}$-n do Estatuto da Cidade já previa instrumentos que incidissem mais diretamente sobre a recuperação da valorização da terra, como a Outorga Onerosa do Direito de Construir (OODC), que pode ser cobrada sobre a permissão de construir e a Outorga Onerosa de Alteração de Uso (OOAU), que pode ser cobrada sobre a permissão de urbanizar ou mudar de um uso menos rentável para um mais (geralmente mudança de uso habitacional para comercial, entre outras possíveis) (SANTORO, 2012, p. 158) Entretanto, a lei 12.608 de 2012 parece inovar na questão uma vez que condiciona a ampliação do perímetro à existência desses mecanismos.

A professora Paula Santoro (2012) chama a atenção para o estágio embrionário da discussão sobre esses dispositivos, o que é bastante inadequado visto que os municípios não só tem o direito, mas o dever de intervir em processos especulativos que resultem em valorizações excessivas da terra. A aplicação dos mecanismos de outorga onerosa parece enfrentar fortes resistências no mundo do direito, que considera essa recuperação de valores uma argumentação muito mais política do que de fato hábil para evitar a captura da mais valia urbana. Entretanto, é de se esperar que os agentes dominantes e a indústria de construção civil não endossem a aplicação de outorgas, afinal, isso representaria o fim de uma série de confortos e benefícios econômicos garantidos ao longos de décadas. Nesse 
sentido, a urbanista Ermínia Maricato (2001, p. 111) argumenta que os instrumentos de Operação Urbana e Outorga Onerosa podem, dependendo de como se dá sua aplicação, representar um avanço social e político ou reafirmar o primado absoluto do mercado. Para a autora, o texto da lei "não garante que o poder público não seja capturado por interesses privados ao investir os recursos captados na valorização da própria área e, com isso, favorecer apenas os empresários que aí investem"

A mudança que a lei propõe na política periurbana é bastante recente, o que dificulta uma análise de constatação de efeitos. Entretanto, a pesquisadora Raquel Tomanik (2017) apresenta um estudo de caso da cidade de Betim (MG) em que é possível vislumbrar alguns prós e contras:

\begin{abstract}
O que se observa, a partir do caso do município de Betim, é que a interpretação do artigo 42-B como uma relação de itens a serem atendidos nos projetos de ampliação do perímetro urbano, apesar de atribuir maior qualidade à nova expansão urbana, sobretudo pela diversidade de usos que impõe a ela, não tem sido medida capaz de garantir a gestão equilibrada do território. Tal interpretação segue instruções da Agência RMBH, órgão responsável pelo planejamento metropolitano, que orienta que os projetos específicos devem contemplar todos os itens do artigo 42-B5 . A preocupação da Agência RMBH é legítima, já que a realidade dos 34 municípios que compõem a região metropolitana sob sua responsabilidade é diversa tanto em especificidade territorial quanto em estrutura administrativa. A RMBH, apesar de figurar entre as poucas regiões metropolitanas brasileiras com capacidade governativa (Compans, 2015), é marcada por desigualdades institucionais e financeiras que dificultam a gestão do espaço pelos municípios (Costa, 2012). A intervenção do Estado, que atualmente elabora proposta de um macrozoneamento metropolitano, como reflexo do PDDI elaborado recentemente e em cumprimento às exigências do Estatuto da Metrópole, mostra-se necessária para controlar a expansão da área urbana dos municípios, sobretudo daqueles que despertam maior interesse no mercado imobiliário e que sofrem pressão pela ampliação de seu perímetro urbano. (TOMANIK, 2017, p.9)

Assim como Betim, vários municípios, metropolitanos ou não, possuem instrumentos jurídicos capazes de lidar com a gestão de seu território. Entretanto, tais instrumentos não são acompanhados de regras de aplicação, ficando essa ação a cargo daqueles que os implementam. Sendo assim, é importante considerar em que medida a interpretação das normas tem trazido mais problemas do que solução e questionar: é de mais regulamentos que se precisa? Em análise do histórico da Lei Federal $\mathrm{n}^{\circ}$ 6.766, de 1979, que dispõe sobre o parcelamento do solo urbano, Blanco (2008), ao parafrasear Edésio Fernandes, destacou que "o problema no Brasil não é de falta de leis, é de leitura". Seguindo o destaque do autor, cabe discutir se o Estatuto da Cidade, um marco regulatório reconhecido internacionalmente, necessitaria de complementos, tais como o artigo 42-B, ou se as novas medidas já não estariam contempladas nos regulamentos existentes. (TOMANIK, 2017,p 12)
\end{abstract}

A partir do caso em estudo, a autora confirma que só produzir o mapeamento de uma área para determinada finalidade não é capaz de forçar o cumprimento da função social da cidade e da terra urbana. A viabilidade de aplicação dos dispositivos do artigo 42-B parece depender muito mais da escala em que se insere a elaboração do projeto específico de alteração. Isto é, não seria necessário revisar toda a lei quando da necessidade de ampliação 
do perímetro urbano, mas analisar casuisticamente as demandas e as propostas apresentadas setorialmente, inclusive quanto à adequação ao artigo 42-B nas áreas confrontantes. "Tal situação poderia ser vencida a partir de diretrizes que considerassem a área de influência imediata da ampliação do perímetro urbano e não somente a interpretação do artigo 42-B como um check-list de parâmetros atendidos e não atendidos". (TOMANIK, 2017, p. 12)

Ainda, toca-se num ponto bastante pertinente sobre a acumulação de regramentos que só deixam ainda mais confusa a solução de conflitos, criando espaço para os "exploradores" do direito. (se beneficiam da indefinição para travar o sistema jurídico a seu favor).

\subsubsection{A política habitacional em tempos de financeirização}

Conforme abordado em tópicos anteriores, a década de 70 e o início da década de 80 foram marcadas pelo fortalecimento do $\mathrm{BNH}$ como promotor das moradias populares. Rolnik (2015) elucida que esse novo impulso se deu tanto por influência política do Banco Mundial como por fomento do II Plano Nacional de Desenvolvimento (II PND), que tirou prioridade das indústrias de construção, automobilística e de bens de consumo duráveis para as de bens de capital e construção pesada. Nesse período houve grande expansão urbana com a construção das Cohabs, que povoaram boa parte das periferias das cidades, bem como pela introdução de programas de apoio à autoconstrução (por exemplo lotes urbanizados e financiamento de centros sociais e equipamentos urbanos nos conjuntos já implantados)

No final dos anos 80 o $\mathrm{BNH}$ e todo o complexo sistema que o sustentava foi paralisado principalmente pela falta de liquidez diante do grave quadro inflacionário que o país se encontrava, bem como pela recessão da economia e seu consequente aumento na inadimplência, abrindo rombos nas contas do banco. "Pesou também para sua extinção a ruptura da coalização de interesses empresariais e políticos que se articularam para sua criação, em um quadro mais geral de crise do regime ditatorial e de base de sustentação econômica e política" (ROLNIK, 2015, p. 286)

Nos anos 90, durante a gestão do governo Fernando Henrique Cardoso (PSDB), houve importantes mudanças estruturais como a reforma monetária, com lançamento do plano Real, e a abertura do mercado para bancos estrangeiros. O "choque de mercado" produzido por essa política visava à seleção de bancos mais aptos, modernizando o sistema financeiro nacional, além de aumentar a fluidez de capital internacional. Nesse mesmo contexto, o setor imobiliário foi alvo de importantes reformas liberalizantes. A Associação 
Brasileira de Entidades de Crédito Imobiliário e Poupança (ABECIP) foi grande entusiasta da criação de uma Sistema Financeiro Imobiliário, nos moldes do sistema de hipotecas dos Estados Unidos, com o intuito de ampliara participação do capital financeiro no mercado imobiliário. Eis a origem dos Certificados de recebíveis imobiliários (CRI); fundos de investimento imobiliários (FII), leis específicas para secutirizadoras de crédito imobiliário, criação do regime de alienação fiduciária (ROLNIK, 2015, p. 286-287; ROYER, 2013)

Nesse mesmo período o governo PSDBista lança dois programas de habitação social - o primeiro deles foi o PAR (Programa de Arrendamento Residencial), em que o empreendedor privado ficava responsável pela operação desde a compra do terreno, até o projeto e construção. O governo municipal participaria apenas da seleção da demanda e o governo federal ficaria incumbido de financiar diretamente, subsidiando o mutuário através da Caixa Econômica Federal - que absorveu boa parte da estrutura e dos recursos do BNH. O segundo programa foi o PSH - Programa Social de Habitação e, nesse caso, o Estado leiloava subsídios por região e bancos de segunda linha podiam adquiri-los para, em parceria com os municípios, construir casas. (ROLNIK, 2015, p. 289). Importante salientar que nesse momento ${ }^{23}$ o financiamento direto ao mutuário, bem como demais cartas de crédito individuais, absorveram $76 \%$ dos recursos do FGTS para a construção de moradias destinadas às classes médias (ROLNIK, 2015, p. 289).

A gestão de Lula, a partir de 2002, dá continuidade ao perfil financeirizado da política habitacional, mas com três estratégias diferentes de ampliação do crédito e fomentando a venda de moradia :

- regulamentação da alienação fiduciária, permitindo que a modalidade coexistisse com o princípio de "bem de família" (bastante indigesto para os investidores do ramo imobiliário)

- resolução do Banco Central determinando que os bancos aplicassem uma porcentagem do Sistema Brasileiro de Poupança e Empréstimo (SBPE) e do Fundo de Compensação das Variações Salariais (FCVS) em empréstimos imobiliários;

- Proposição da "MP do Bem” (MP 252 de 2004) que dava insenção de imposto a venda de imóveis, desde que seu resultado fosse imediatamente aplicado na compra de outro imóvel residencial. (ROLNIK, 2015, p. 289-290)

A disseminação dos recursos financeiros pelo sistema imobiliário aumentou o poder de controle das subsidiárias de crédito, transformando-as também em securitizadoras

\footnotetext{
${ }^{23}$ Entre 1995 e 1998
} 
e submetendo as estratégias das construtoras à lógica de seu braço financeiro. "Em muitos casos, os CEOs dos fundos também assumiram posições de comando na empresa, integrando seus conselhos de administração e cargos gerenciais “ (ROLNIK, 2015, p. 292). Em 2014, das 22 empresas de construção listadas na Bovespa, 9 centravam 37 bilhões de dólares em terra, totalizando quase 620 mil quilômetros quadrados de solo urbano, em várias cidades do país. (ARAGÃO, 2014) Tamanho afluxo de capital tem grande poder de barganha sobre as prefeituras que, quase sempre endividadas, disputam entre si os investimentos flexibilizando leis urbanísticas, por exemplo aumentando a área de expansão urbana e abrindo as terras rurais para a dinâmica financeira da habitação.

Enquanto isso, na esfera federal, o governo continua a utilizar recursos de fundos públicos ou de gestão pública como o Fundo de Amparo ao Trabalhador - FAT e Fundo de Garantia do Tempo de Serviço - FGTS, para propiciar condições favoráveis ao empresariado investir em habitações, seguindo a lógica do mercado financeiro. Em 20112012, por exemplo, o Programa Minha Casa Minha Vida alocou recursos para habitação e estabeleceu metas relativas à construção de um milhão de moradias, destas 400 mil destinadas a famílias com renda familiar entre zero e três salários mínimos. Foi disponibilizado quase um bilhão de reais para que o programa concluísse essa fase, sendo que destes, o maior volume de recursos está destinado para a produção privada de habitação através de empreendimentos privados ou de recursos para o beneficiário final, enquanto isso foi disponibilizado um volume 46 menor para o Minha Casa Minha Vida entidades ${ }^{24}$, através do FNHIS, menos de 10\% do recurso total investido (SANTORO, 2012, p. 131). Isto é: muito embora a gestão pública do período estivesse de fato preocupada com a questão habitacional, produzindo centenas de moradias populares, o modelo escolhido para a política pública ainda se baseia na abertura de terras para a financeirização, criando uma série de efeitos negativos (principalmente para a população que passa a viver nesses empreendimentos).

Seja para o rentismo dos investidores, seja para políticas públicas financeirizadas de moradia popular, o modelo de organização do solo no Brasil envolve a disponibilização de

\footnotetext{
${ }^{24}$ O Programa Minha Casa, Minha Vida - Entidades, foi criado em 2009, com o objetivo de tornar a moradia acessível às famílias organizadas por meio de cooperativas habitacionais, associações e demais entidades privadas sem fins lucrativos. O programa, ligado à Secretaria Nacional de Habitação do MInistério das Cidades, é dirigido a famílias de renda familiar mensal bruta de até $\mathrm{R} \$ 1.600,00$ e estimula o cooperativismo e a participação da população como protagonista na solução dos seus problemas habitacionais.
} 
terras para dar continuidade dos processos capitalistas de acumulação. Não à toa, esse processo se dá através de ações públicas como aumento do perímetro urbanizável; "manutenção de políticas e planos que, por muito tempo, evitaram tratar do tema da expansão urbana ou regular o crescimento urbano horizontal; liberação das áreas que eram objeto de restrições à ocupação ou adensamento, como é o caso de áreas com restrições ambientais. Nesse sentido, Paula Santoro é contundente (2012, p. 137-138):

\begin{abstract}
Neste processo de transição de uso rural para urbano há uma grande valorização da terra que beneficia proprietários, que mantém altas rentabilidades e a possibilidade de especular com a terra, geralmente onerando a gestão pública que tem que ampliar serviços e oferta de equipamentos sociais, nem sempre produzindo espaços justos, com mesclas sociais e com qualidade urbanoambiental. E, principalmente, raramente está voltado para atender as necessidades urbanas e habitacionais da população, ou mesmo processos de crescimento populacional (Santoro \& Bonduki, 2009). Mesmo reconhecendo o ônus público da opção de crescer de forma dispersa, as políticas de flexibilização têm acontecido, sem medir as conseqüências para o urbano.
\end{abstract}

\title{
2.6.4. A Lei $n^{\circ} 13.465 / 2017$ (Medida Provisória 759 de 2016)
}

Após a destituição de Dilma Roussef, em 2016, o governo de Michel Temer e sua base aliada lançou em tempo record um pacote de grandes alterações no ordenamento brasileiro, modificando direitos e garantias já consolidados. Uma das primeiras e mais profundas alterações empreendidas pelo governo foi a proposição da PEC 241/55 ("PEC do teto"), cujo conteúdo prevê, dentre outros, o congelamento dos gastos com saúde e educação pelos próximos $20 \operatorname{anos}^{25}$. Ainda, em março de 2017 a Câmara aprovou um projeto de lei que permitiu a terceirização do trabalho em qualquer tipo de atividade, não mais apenas nas atividades-meio. ${ }^{26}$ Em julho de 2017 aprovou a reforma trabalhista, alterando a CLT em mais de 100 artigos. Segue em votação a proposta de reforma da previdência, também bastante criticada pela falta de grandes debates públicos e pela abrupta elevação no tempo mínimo de trabalho ${ }^{27}$.

É nesse contexto de reformas relâmpago que em 31 de maio de 2017 foi aprovada a Medida Provisória no 759 (atual Lei 13.465/2017), substituindo as leis 8.629/1993 e 11.952/2009, estabelecendo novas regras para "regularização fundiária rural e urbana, sobre a liquidação de créditos concedidos aos assentados da reforma agrária e sobre a regularização fundiária no âmbito da Amazônia Legal, institui mecanismos para aprimorar

\footnotetext{
25 Aprovada. Transformada na Emenda Constitucional no 95 de 15/12/2016

26 PL 4302/1998 . Transformado na Lei Ordinária 13429/2017

${ }^{27} 65$ anos para homens, 62 anos para mulheres.
} 
a eficiência dos procedimentos de alienação de imóveis da União". Seja no âmbito urbano, seja no rural, a medida é mais uma dentre uma série de leis que tratam da possibilidade de regularização de terras ocupadas irregularmente com casas, condomínios, comércios, indústria e todo tipo de uso e formas de ocupação do solo. Ou seja: altera as condições de acesso à terra, o que pode ter grandes consequências nos processos de expansão urbana e na organização da zona rural.

Tão logo foi aprovada a MP passa a ser propagandeada pelo site oficial da Secretaria Especial de Agricultura Familiar e do Desenvolvimento Agrário, vinculada ao Ministério da Casa Civil. Segundo a notícia de 01 de Junho de $2017^{28}$ o dispositivo promete dar celeridade ao processos de regularização fundiária e cita pequenos agricultores familiares como principais beneficiários. De acordo com o secretário José Ricardo Roseno ${ }^{29}$, da SEAD, as novas regras representam a evolução da política de regularização fundiária no país. "Estamos modernizando a Reforma Agrária e o Programa Terra Legal com foco na titulação. Vamos aumentar a velocidade da documentação de terras e, assim, eliminar o que ainda é hoje o principal gargalo para melhorar a relação dos agricultores familiares com as políticas às quais eles têm direito".

Entretanto, não parece haver a mesma impressão positiva por parte de profissionais da área. No dia $1^{\circ}$ de fevereiro de 2017 o Instituto dos Arquitetos do Brasil (IAB-SP) e o Instituto Brasileiro de Direito Urbanístico (IBDU) organizaram um evento em São Paulo para debater ${ }^{30}$ o tema tão complexo justamente por ter sido proposto de modo tão apressado. Dentre os presentes, a advogada Roseane Tierno (2017) pontuou uma série de aspectos problemáticos no âmbito jurídico, que vão desde conflitos de competência até grilagem de terra pública.

Registros Públicos: A Lei no 13.465/2017 (MP) revogou um sistema complexo de leis de regularização fundiária que vinha sendo construído desde a década de 70, abrangendo diferentes áreas do direito. A Lei 6015 de 1973 (lei nacional de registros públicos), por exemplo, instrui cuidadosamente como deverão ser feitos os registros e a

\footnotetext{
${ }^{28}$ BRASIL.Secretaria Especial de Agricultura Familiar e do Desenvolvimento Agrário, Ministério da Casa Civil. Disponível em http://www.mda.gov.br/sitemda/noticias/regulariza\%C3\%A7\%C3\%A3ofundi $\%$ C3\%A1ria-modernizada-foi-aprovada-no-senado-mp-759. Acessado em 08/07/2017

${ }^{30}$ A pelestra aconteceu em São Paulo, do dia 01 de fevereiro, no prédio do IAB às 18:30. O vídeo do debate está disposto no endereço: https://www.youtube.com/watch?v=908RTkTFvoI
} 
escrituração de imóveis (Arts. 168-173). Segundo a advogada, esse procedimento detalhista foi introduzido justamente para que se pudesse ter uma base burocrática clara e objetiva, facilitando a regularização fundiária. No entanto, a aprovação da medida provisória de Michel Temer torna obsoleto esse dispositivo. O diploma normativo não foi capaz de abranger toda a complexidade do tema e, agora, deixou uma série de lacunas que podem atrasar ainda mais o processo de regularização fundiária. Além disso, esses vazios deixado pela MP deverão agora ser regulados por decreto, muito embora os legisladores não tenham se atentado para o fato de que certas matérias, como registro público, tem reserva legal e não poderão ser abarcadas por esse tipo normativo.

Conflito de competência e estagnação da regularização: Outra lei colocada em cheque é a 11. 977 de 2009, que dispões sobre regularização fundiária urbana e sobre as disposições do programa Minha Casa Minha Vida. Como se percebe, existem leis ainda bastante recentes e atualizadas tratando da matéria, não havia necessidade de uma intervenção tão drástica e tão apressada. Um dos problemas apontados é que muitos Planos Diretores do país adotaram os princípios da 11.977/09 em seu conteúdo e agora, com a obsolescência da lei, a regularização fundiária fica pendente de nova regulação. O problema se agrava porque ao contrário do arcabouço jurídico que se tinha antes, essa MP não é autoaplicável e provocará estagnação no processo de regularização fundiária no país - ou pelo menos até que todos os provimentos dos tribunais e das leis urbanísticas (planos diretores, leis de uso e ocupação do solo, etc) sejam devidamente readequados. Inclusive uma série de provimentos dos tribunais e do $\mathrm{CNJ}$ orientavam o procedimento notorial dos cartórios com base na lei 11.977 e, agora, essa instrução está em suspenso. Além disso, vale ressaltar que agora existe uma MP federal legislando sobre bens de outro ente da federação.

Licenciamento ambiental - A maior parte da população de baixa renda mora em regiões ambientalmente frágeis, justamente por serem a único espaço disponível fora da cidade oficial. Sendo assim, o banco de terras a ser regularizado geralmente envolve zonas de proteção ambiental. A lei 11.977 de 2009, ao longo de sua elaboração, negociou critérios muito bem estabelecidos para conciliar os dois interesses, criando um resultado tão satisfatório que o capítulo foi incorporado no novo código florestal. A Lei n ${ }^{\circ}$ 13.465/2017 revoga esse ponto e não demonstra uma alternativa.

Regularização e infraestrutura - A Lei $n^{\circ}$ 13.465/2017 permite que tenha regularização sem que a região seja dotada de infraestrutura urbana mínima. Além de 
regular matéria urbanística de competência municipal ela priva que as novas áreas recémregularizadas tenham a mesma qualidade urbana (e de vida) que desfrutam os bairros formais, cheios de investimentos públicos. A medida provisória permite que uma área seja regularizada desde que a prefeitura apresente um cronograma de obras a ser registrado em cartório (o chamado CRF - Certificado de Regularidade Fundiária), com valor de título executivo extrajudicial. Entretanto, Tierno (2017) prevê que muitas prefeituras emitirão o registro em uma gestão e deixarão o título executivo para outras gestões, terceirizando o problema e tornando ainda mais crônica a falta de qualidade urbana. Vale lembrar que as regiões regularizadas sem infraestrutura continuam a causar problemas não só para os moradores, mas para toda a cidade. Ocupações em beira de rio, por exemplo, podem assorear as margens e comprometer o abastecimento de água da cidade.

Nomenclatura: A Lei $\mathrm{n}^{\circ}$ 13.465/2017 também inclui um conceito de "Núcleo Urbano" que é estranho à nomenclatura nacional e internacional da área, que geralmente se refere a esses espaços como "assentamentos irregulares". Roseane ressalta o quão falacioso é chamar um assentamento sem infraestrutura de núcleo urbano sem que o próprio poder público se responsabilize a levar urbanidade para lá. A mudança de nomenclatura pode induzir ao errôneo entendimento de que essas regiões não mais carecem de investimentos ou melhoramentos. Ainda, pode alterar a gestão das ZEIS (Zonas Especiais de Interesse Social) já que em muitos programas de captação de recursos para áreas vulneráveis a legislação vincula o recebimento de acordo com a classificação (nome) no mapeamento. A alteração do nome pode gerar confusão e comprometer a arrecadação das zonas atualmente definidas como ZEIS, travando uma série de benefícios já iniciados. Isso se deve, também, pela tentativa de tentar unificar a resolução do problema em uma única norma, com nomenclaturas unificadas e procedimentos centralizados, como se a pluralidade de instrumentos e leis fosse algo prejudicial. A Lei $n^{\circ}$ 13.465/2017 ignora que a diversidade de mecanismos é essencial para regular matérias fundiárias e urbanísticas justamente pela complexidades de áreas jurídicas envolvidos e as especificidades de cada município.

\section{Regularização ou grilagem?}

O Art. 11 da A Lei no 13.465/2017 define duas modalidades de Regularização Fundiária Urbana (Reurb): I - Reurb de interesse social - Reurb-S - aplicável a núcleos urbanos informais ocupados predominantemente por população de baixa renda, observado o disposto em ato do Poder Executivo federal; II - Reurb de interesse específico - Reurb-E 
- aplicável a núcleos urbanos informais ocupados por população não qualificada na hipótese de que trata o inciso I. (ou seja, população de média e alta renda).

Nos artigos 11 a 18 são estabelecidos dezenas de critérios e requisitos para que se posse conseguir a Reurb-S (de baixa renda), mas não há óbices burocráticos quanto à Reurb-E Além disso, o Art. 21 determina que a legitimação fundiária constitui forma originária de aquisição do direito real de propriedade, conferido por ato discricionário do Poder Público "que detiver área pública ou possuir área privada, como sua, unidade imobiliária com destinação urbana, integrante de núcleo urbano informal consolidado.

Sendo assim, é possível que um posseira, não enquadrado na reurbanização de interesses social (rico), adquira justo título de propriedade via modo originário de aquisição, através de uma medida discricionária da prefeitura, sem grandes entraves burocráticos. (inclusive sobre terras públicas, da União). Além de viabilizar a anistia de grilagens sobre terra pública, a discricionariedade do dispositivo coloca em cheque a segurança jurídica da propriedade privada. (TIERNO, 2017)

Os problemas encontrados no texto normativo foram tantos que o Ministério Público do Distrito Federal e Territórios (MPDFT) elaborou nota técnica em repúdio à então Medida Provisória (Nota Técnica $n^{\circ}$ 1/2017- PROURB/PRODEMA/PDDC) No documento, a instituição defende que o Congresso Nacional rejeite a norma ou adeque diversos dispositivos que, se não forem alterados, poderão ser considerados inconstitucionais, seja pela ausência do requisito de urgência para edição de medida provisória, seja pelo comprometimento da promoção do equilíbrio ambiental e ao cumprimento da função social da propriedade urbana, seja pela ampla anistia para quem ocupou o solo ilegalmente até a data mencionada. ${ }^{31}$ :

Uma das irregularidades apontadas pelo MPDFT é a ausência do requisito de urgência para edição de medida provisória. De acordo com a nota, a matéria é complexa e altera significativamente a legislação sobre o tema, que já havia sido modificada em julho de 2009. Por essa razão, não deveria ser tratada por medida provisória, sem debate prévio com a sociedade.

O MPDFT considera que as novas regras dão maior importância à titulação que aos demais objetivos da regularização fundiária, que dizem respeito à mitigação dos danos urbanísticos e ambientais decorrentes da ocupação desordenada. Com isso, amplia-se o risco de que o processo de regularização se transforme em mera oficialização das situações já existentes, sem as contrapartidas necessárias à promoção do equilíbrio ambiental e ao cumprimento da função social da propriedade urbana.

\footnotetext{
${ }^{31}$ BRASIL. MPDFT é contrário à Medida Provisória 759/2016. Criado em 26 de Abril de 2017, às 14:51. http://www.mpdft.mp.br/portal/index.php/comunicacao-menu/noticias/noticias-2017/9196-mpdft-econtrario-a-medida-provisoria-759-2016
} 
Da forma como foi apresentado, o texto da MP $n^{\circ}$ 759/2016 considera beneficiários da regularização fundiária todos aqueles que detenham área pública ou que possuam área privada, a qualquer título. A regra não exclui a posse violenta, clandestina, precária ou de má-fé, o que transforma a medida provisória em anistia para quem ocupou o solo ilegalmente até 23 de dezembro de 2016. Para o MPDFT, a nova regra premia pessoas que continuaram infringindo a legislação após a edição das leis $n^{\circ} 11.977 / 2009$ e $n^{\circ} 12.651 / 2012$ e alimenta a "cultura da regularização", que tolera e incentiva situações ilegais na expectativa de que um dia venham a ser regularizadas.

A MP $n^{\circ} 759 / 2016$ também altera as regras anteriores ao estender benefícios antes aplicáveis somente à regularização fundiária de interesse social (de baixa renda) à regularização fundiária de interesse específico, o que alcança ocupações de médio e alto poder aquisitivo. Além disso, abrange não apenas as áreas ocupadas para fins de moradia, mas também imóveis destinados a atividades profissionais ou comerciais, ainda que situadas em áreas classificadas como rurais. Essa modificação permite a dispensa de exigências relativas ao percentual e às dimensões de áreas destinadas ao uso público, entre outros parâmetros urbanísticos. Para as ocupações em áreas públicas, a medida provisória também dispensa a desafetação e a observância da Lei de Licitações.

Outra alteração que preocupa o MPDFT são os retrocessos em relação à proteção ao meio ambiente. Além de não prever a necessidade de licenciamento ambiental do projeto de regularização fundiária, a MP n 759/2016 admite a regularização de núcleos urbanos informais existentes até a data de sua publicação (23/12/2016) em Áreas de Preservação Permanente (APP) e em áreas de risco, com base em estudos técnicos que demonstrem a viabilidade dessas ocupações, independentemente da condição social dos beneficiários.

Para o MPDFT, é essencial que a política de regularização fundiária esteja em sintonia com as diretrizes estabelecidas pelo Estatuto das Cidades e pelas políticas nacionais de proteção ao meio ambiente, de mobilidade urbana e de defesa civil. Além disso, os prazos curtos e a excessiva informalidade do procedimento instituído pela medida provisória podem se transformar em fonte de insegurança jurídica, inclusive para o sistema de registro de imóveis.

A Instituição sustenta, ainda, que são os municípios e o Distrito Federal que devem decidir quais áreas poderão ser utilizadas para fins urbanos e quais deverão permanecer como rurais, assim como os tipos de atividades econômicas exploradas nesses locais. Essa definição só poderá ocorrer pela alteração das legislações locais, que deve ser precedida de audiências públicas e debates com a participação da comunidade, sob pena de violação das diretrizes gerais da política de desenvolvimento urbano fixadas pelo Estatuto das Cidades.

De acordo com Raquel Rolnik 1997) há um padrão lógico em leis como essa ao longo da história, em que estabelecem uma data limite para anistiar somente aqueles que ocupam uma área irregularmente até a data de sua publicação, ou seja, o que já foi ocupado. Esse procedimento reforça (e resgata) um modelo que determina a organização territorial do Brasil desde a metade do século 19, com a lei de terras de 1850: a posse é reconhecida para alguns (ricos) e bloqueada para outros (pobres). Ainda que tanto fazendeiros quanto moradores de favela estejam numa mesma situação jurídica (irregular), vigoram mecanismos que permitem às pessoas com mais recursos regularizar essas terras a posteriori, aproveitando-se da influência política e da confusão normativa. Os pobres, por sua vez, são alvos de barganhas eleitorais que condicionam o apoio ao candidato à 
regularização e o reconhecimento de seus direitos de posse, mantendo-os sempre em uma condição de subalternidade. Nesse ponto, James Holston (2013) é brilhante ao expor a dualidade normativa no sistema jurídico brasileiro, em que a legalidade do território paira sobre um critério de classe, entremeando-se entre o regular e o irregular de acordo com a vontade do poder dominante:

\begin{abstract}
o sistema jurídico brasileiro não objetiva nem resolver os conflitos de terra de maneira justa, nem decidir sobre seus méritos legais através de procedimentos judiciais. Meus argumentos enfatizam a norma e a intenção pelas quais, no Brasil, a lei da terra, nos seus próprios termos, é tão confusa, indecisa e disfuncional. E possível suspeitar que as causas dessas características não sejam somente incompetência e corrupção, mas a força de um conjunto de intenções subjacentes às suas construção e aplicação, intenções essas bem diferentes daquelas voltadas para as resoluções das disputas. Assim, argumento que a lei brasileira produz regularmente, nos conflitos de terra, procedimentos e confusão irresolúveis; que essa irresolução jurídico-burocrática às vezes dá início a soluções extrajudiciais; e que essas imposições políticas, inevitavelmente, terminam por legalizar algum tipo de usurpação. Em suma, a lei de terra no Brasil promove conflito, e não soluções, porque estabelece os termos através dos quais a grilagem é legalizada de maneira consistente. É, por isso, um instrumento de desordem calculada, através do qual práticas ilegais produzem lei, e soluções extralegais são introduzidas clandestinamente no processo judicial. Nesse contexto repleto de paradoxos, a lei é um instrumento de manipulação, complicação, estratagema e violência, através do qual todas as partes envolvidas - dominadoras ou subalternas, o público e o privado - fazem valer seus interesses. A lei define, portanto, uma arena de conflito na qual as distinções entre o legal e o ilegal são temporárias e sua relação é instável (HOLSTON, 2013, p. 265-266)
\end{abstract}

Se a utilização do perímetro urbano já era alvo de pressão econômica por parte de grandes construtoras, agora ela pode se tornar obsoleta vez que cada "núcleo urbano" que se forma fora do estabelecido pode ser alvo de regularização discricionária a posteriori. 


\section{INTERAÇÕES JURÍDICAS CONFLITUOSAS ENVOLVENDO O PERÍMETRO URBANO}

A cronologia da política urbanística não deixa dúvidas sobre as grandes disputas econômicas envolvendo a ocupação da terra, principalmente na região periurbana, reforçando a teoria de Harvey sobre a necessidade que o sistema capitalista tem em se expandir territorialmente para dar continuidade aos processos de acumulação. Não ficam dúvidas, também, sobre o quanto a colonização desses novos espaços geralmente favorece grupos dominantes de alta renda, que se utilizam da legislação urbanística para tecer camadas de (i)legalidade a seu favor, e assim vão definindo o perfil e a qualidade da cidade e do campo a despeito dos interesses coletivos. Ainda, foi demonstrado que o novo perfil da acumulação capitalista iniciado após a década de 70, se baseia num complexo sistema financeiro que dá liquidez ao valor do solo, permitindo uma capilaridade de investimentos que abre ou fecha o acesso à terra a determinadas camadas sociais. Nesse processo, objetivos como "justiça social" e "conservação" vão sendo gradualmente convertidos em objetivos de eficiência e racionalidade do mercado, "com um toque de muito socialismo para os ricos, auxílio financeiro para empresas e instituições financeiras pouco sólidas" (HARVEY, 2005, p. 77). Sendo assim, é possível vislumbrar a razão pelo qual o perímetro urbano geralmente é alterado (quando não há estudo ou justificativa técnica para tanto). A próxima tarefa neste capítulo será, portanto, mensurar e descrever os impactos que essa alteração nem sempre motivada pode ter tanto na interação com outros dispositivos do ordenamento como na organização da vida urbana e rural.

\subsection{Legislação Ambiental}

Nos primeiros anos da década de 1960 o Brasil enfrentava dificuldades de crescimento econômico. Por conta disso, o governo federal do regime militar tentou incentivar a exportação de produtos industrializados, inclusive de natureza agrícola, motivo pelo qual concedeu crédito rural para a atualização tecnológica do campo (GRAZIANO DA SILVA, 1982). A institucionalização do crédito rural se dá em 1965 na tentativa de integrar o setor agrícola ao industrial e promoveu uma verdadeira corrida para o oeste em busca de terras agricultáveis, principalmente no interior de São Paulo e do Rio de Janeiro, posteriormente avançando para Goiás, Mato Grosso do Sul, Mato Grosso, entrando inclusive em áreas da Amazônia Legal. Esse processo de expansão da fronteira agrícola teve grande impacto nos biomas que encontrou pelo caminho, desde a Mata Atlântica até Amazônia, passando pelo Cerrado (SANTORO, 2012, p. 96) 
Diante desse cenário houve esforço para regular a ocupação desses novos espaços e conciliar o crescimento econômico com a conservação ambiental. Em 1965 também foi aprovado o Código Floresta (L. 4.771 de 65), atualizando o Decreto n. 23.793 de 1934, até então o dispositivo normativo dedicado à essa matéria. Dentre as novidades em destaque está a introdução do conceito de Preservação Permanente, que limitava a exploração da propriedade florestada da seguinte maneira, segundo a redação original da lei (BRASIL, 1965):

Art. 16. As florestas de domínio privado, não sujeitas ao regime de utilização limitada e ressalvadas as de preservação permanente, previstas nos artigos $2^{\circ} \mathrm{e}$ $3^{\circ}$ desta lei, são suscetíveis de exploração, obedecidas as seguintes restrições:

a) nas regiões Leste Meridional, Sul e Centro-Oeste, esta na parte sul, as derrubadas de florestas nativas, primitivas ou regeneradas, só serão permitidas, desde que seja, em qualquer caso, respeitado o limite mínimo de $20 \%$ da área de cada propriedade com cobertura arbórea localizada, a critério da autoridade competente;

c) nas regiões citadas na letra anterior, nas áreas já desbravadas e prèviamente delimitadas pela autoridade competente, ficam proibidas as derrubadas de florestas primitivas, quando feitas para ocupação do solo com cultura e pastagens, permitindo-se, nêsses casos, apenas a extração de árvores para produção de madeira. Nas áreas ainda incultas, sujeitas a formas de desbravamento, as derrubadas de florestas primitivas, nos trabalhos de instalação de novas propriedades agrícolas, só serão toleradas até o máximo de $50 \%$ da área da propriedade;(BRASIL, 1965)

Posteriormente é alterado o código florestal e especificados os critérios de configuração da Área de Preservação Permanente e é incluído o conceito de Reserva Legal, determinando os percentuais de preservação nas propriedades (a depender do bioma). Santoro (2012, p. 97) explicita que o código estendia a necessidade de se manter uma reserva legal "a qualquer propriedade, independentemente de sua localização, fosse urbana ou rural, portanto deveria ter funcionado como uma regra que limitava a ocupação urbana, independentemente de qual fosse o tamanho e localização da propriedade". Isso se comprova pela redação da Lei. $\mathrm{n}^{\circ} 7.803$ de 1989, que altera o código florestal e determina a aplicação às áreas de cerrado a reserva legal de $20 \%$ (vinte por cento) para todos os efeitos legais. (art. 16, $\S 2^{\circ}$ ); e no art. 44 estabelecia que a reserva legal entendida a área de, no mínimo, $50 \%$ (cinqüenta por cento), de cada propriedade, onde não é permitido o corte raso. Isto é, em nenhum momento havia distinção quanto a localização dentro ou fora da zona urbana, tendo grande abrangência.

Entretanto, em 2001 o então presidente Fernando Henrique Cardoso propõe a Medida Provisória n 2.166-67 cujo conteúdo restringiu a proteção apenas para áreas rurais, inserindo um parágrafo no Código Florestal que conceitua a reserva legal como sendo propriedade ou posse rural, excetuada a de preservação permanente, necessária ao uso 
sustentável dos recursos naturais, à conservação da biodiversidade e ao abrigo e proteção de fauna e flora nativa (CASTRO, 2016; SANTORO, 2012). Eis a redação da MP na íntegra:

\begin{abstract}
“Art. $1^{\circ}$, III - Reserva Legal: área localizada no interior de uma propriedade ou posse rural, excetuada a de preservação permanente, necessária ao uso sustentável dos recursos naturais, à conservação e reabilitação dos processos ecológicos, à conservação da biodiversidade e ao abrigo e proteção de fauna e flora nativas;
\end{abstract}

"Art. 16. As florestas e outras formas de vegetação nativa, ressalvadas as situadas em área de preservação permanente, assim como aquelas não sujeitas ao regime de utilização limitada ou objeto de legislação específica, são suscetíveis de supressão, desde que sejam mantidas, a título de reserva legal, no mínimo:

I - oitenta por cento, na propriedade rural situada em área de floresta localizada na Amazônia Legal;

II - trinta e cinco por cento, na propriedade rural situada em área de cerrado localizada na Amazônia Legal, sendo no mínimo vinte por cento na propriedade e quinze por cento na forma de compensação em outra área, desde que esteja localizada na mesma microbacia, e seja averbada nos termos do $\S 70$ deste artigo;

III - vinte por cento, na propriedade rural situada em área de floresta ou outras formas de vegetação nativa localizada nas demais regiões do País; e

IV - vinte por cento, na propriedade rural em área de campos gerais localizada em qualquer região do País.” (BRASIL, 2001, grifo nosso)

A alteração chama a atenção pois não há qualquer fundamento legal, ou mesmo técnico, que justifique a exclusão da obrigação de manter intacto percentual mínimo de $20 \%$ da floresta existente no imóvel urbano. Akaoui (AKAOUI, 2000, p. 290, apud SANTORO, 2012, p. 96) argumenta que diante dessa alteração muitos municípios definiram suas zonas urbanas em uma canetada da Câmara de Vereadores para, dentre outras razões, "não incidir a obrigação da reserva legal e este fato justifica um aclaramento de que o Código Florestal incide sobre áreas com características rurais, estejam elas em zona urbana ou rural". Santoro identifica que essa interpretação iniciou um verdadeiro furor nas Câmaras de Vereadores para incluir o mais rápido possível grandes partes do território dentro do perímetro urbano evitando, dentre outras consequências, a obrigação de respeitar a reserva legal, o que gerou impactos tanto na produção do espaço urbano como na proteção do meio ambiente. Uma vez que muitas cidades possuíam áreas urbanas cobrindo a maior parte de seu território, era possível lotear em locais distantes da contiguidade urbana. $\mathrm{O}$ grande problema da dispersão urbana descontrolada é que, além facilitar a formação de vazios urbanos, podem ser constituídos vários núcleos habitados em pontos pulverizados 
do mapa, gerando custos extraordinários para o orçamento público prover as localidades com toda a infraestrutura que é de direito. Sem contar que tem grande impacto na organização da zona rural, que se reduz a um grande reservatório de terra esperando para ser urbanizada.

\subsection{Questão tributária}

Assim como o Código Florestal, o Código Tributário Nacional, foi criado no mesmo contexto de centralização administrativa do governo militar. $\mathrm{O}$ dispositivo normativo se destacou por criar norma geral para estabelecer a definição de rural e urbano, visando a otimizar a cobrança de impostos. Geralmente os municípios tinham cada um uma definição própria, com critérios próprios, o que gerava entraves burocráticos e prejudicavam a celeridade da arrecadação fiscal. "Há uma evidente dificuldade de interpretação sobre o que é rural e que é urbano ; e até mesmo por isso, os interesses se manifestam e há uma pressão pelo aumento do perímetro e pela manutenção do imposto rural, permitindo especulação com terras em área de transição rural urbana. (SANTORO, 2012, p. 98)"

Vejamos o que estabelece a lei:

Art. 32. O imposto, de competência dos Municípios, sobre a propriedade predial e territorial urbana tem como fato gerador a propriedade, o domínio útil ou a posse de bem imóvel por natureza ou por acessão física, como definido na lei civil, localizado na zona urbana do Município.

$\S 1^{\circ}$ Para os efeitos deste imposto, entende-se como zona urbana a definida em lei municipal; observado o requisito mínimo da existência de melhoramentos indicados em pelo menos 2 (dois) dos incisos seguintes, construídos ou mantidos pelo Poder Público:

I - meio-fio ou calçamento, com canalização de águas pluviais;

II - abastecimento de água;

III - sistema de esgotos sanitários;

IV - rede de iluminação pública, com ou sem posteamento para distribuição domiciliar;

V - escola primária ou posto de saúde a uma distância máxima de 3 (três) quilômetros do imóvel considerado.

$\S 2^{\circ}$ A lei municipal pode considerar urbanas as áreas urbanizáveis, ou de expansão urbana, constantes de loteamentos aprovados pelos órgãos competentes, destinados à habitação, à indústria ou ao comércio, mesmo que localizados fora das zonas definidas nos termos do parágrafo anterior. 
Numa primeira vista é possível observar que a lei fornece requisitos gerais tanto para evitar o aumento do perímetro urbano sem justificativa técnica, (com fins meramente arrecadatórios), quanto dá critérios mínimos para viabilizar a cobrança de impostos. O CTN também regula Imposto sobre a Propriedade Territorial Rural (ITR), cobrado pela União, hoje com repasses aos municípios. Muito embora o limite de perímetro urbano, aprovado em lei municipal, defina zona urbana de uma cidade e, portanto, determina a incidência de tributos, é possível ter usos agrícolas e cobrar ITR mesmo dentro dessa área. Entretanto, ainda assim é curioso o poder de influência que o Município pode ter em matéria tributária da União com uma simples determinação de perímetro urbano. É o que ilustra a doutrina de Hely Lopes Meirelles (MEIRELLES, 1990, p. 568):

\begin{abstract}
"A competência é privativa e irretirável do Município cabendo à Lei urbanística estabelecer os requisitos que darão à área condição urbana e urbanizável; e, atendidos esses requisitos, a lei especial delimitará o perímetro urbano, as áreas de expansão urbana e os núcleos em urbanização. No segundo caso (efeitos tributários), a lei definidora da zona urbana deverá atender aos requisitos do Código Tributário Nacional (art. $32 \S 1^{\circ} \mathrm{e} 2^{\circ}$ ), estabelecidos para fins meramente fiscais (...) Promulgada a lei municipal instituidora ou ampliadora da zona urbana, a Prefeitura deverá enviar seu texto integral ao INCRA, para a cessação de sua jurisdição sobre a nova área urbana e transferência da competência impositiva federal (ITR) para a municipal (IPTU), incidente sobre o terreno e respectivas construções. (grifo nosso)
\end{abstract}

Interessante observar que a relação CTN-perímetro urbano também pode trazer uma porção de outras consequências secundárias. A Reforma Tributária do período promoveu maior centralização de decisões e de receita o que, portanto, comprometeu a autonomia dos municípios e Estados que tiveram suas receitas enxugadas. (CASTRO, 2016) Consequentemente aumentram-se também as relações políticas escusas e pessoalizadas entre municípios e governo federal vez que a verba da cidade passa a depender de determinações arbitrárias de posições superiores da administração pública. É o que constata Paula Santoro (2012, p. 99):

No que tange a expansão urbana, a falta de autonomia e recursos dificultava a extensão da infraestrutura a partir de recursos próprios, tornando o município dependente de recursos externos para completar sua urbanização. E para ter acesso aos programas do BNH ou do Fundo de Apoio ao Desenvolvimento Social - FAS tinha-se que fazer uma verdadeira via-sacra pelo governo federal, mantendo sua dependência dos poderes centrais, apesar de terem sido eleitas pelo voto direto. Esta dependência ainda é muito atual, muito embora a Constituição Federal de 1988 tenha dado maior autonomia aos municípios, não garantiu que a estrutura de financiamento destes sofresse grandes alterações (Relatório das Cidades Brasileiras, 2010) 


\subsection{O Avanço da Cidade Sobre a Zona Rural}

A expansão urbana avança inevitavelmente sobre algumas terras agrícolas, o que não necessariamente precisa ser vito como algo negativo.O Estauto da Cidade possui uma série de instrumentos dedicados à integração da política rural com a urbana vez que o campo é parte integrande da cidade e não seu antônimo. No entanto, na maioria das áreas urbanas em países de baixa e média renda, a ausência de qualquer plano de uso da terra ou estrutura de planejamento estratégico para orientar as mudanças no uso do solo significa que as áreas urbanas se expandem ao acaso, ou então esse planejamento até existe mas está dominado por um setor específico da hierarquia social que se utiliza dele para reforçar seus privilégios. Na maioria dos casos há pouco controle efetivo sobre as conversões do uso da terra agrícola para usos não-agrícolas, privilegiando interesses imobiliário sobre o agrário. (tradução livre) $^{32}$ (DODMAN et al., 2001).

Os centros urbanos geralmente se expandem sobre a terra agrícola mais produtiva do país, justamente porque a maioria deles cresceu por causa de solos altamente férteis, como é o caso de Ribeirão Preto. Entretanto, é importante diferenciar que as propriedades rurais aqui afetadas negativamente são as pequenas e médias propriedades produtoras de alimentos, distribuídas geralmente pela região periurbana por questões logísticas. Os grandes proprietários de terra, que no caso do interior paulista geralmente se dedicam à monocultura agroexportadora, possuem uma dinâmica diferente (SANTORO, 2012). Nabil Bonduki demontra que entre os anos 1990 e 2000, as oscilações no mercado de commodities agrícolas no interior de São Paulo ora valorizando, ora desvalorizando as culturas de cana e laranja, têm estimulado a mudança do solo rural para urbano através da abertura de novos loteamentos residenciais (Bonduki, 2009). Pelo que indicam os estudos na área, os grandes proprietários de terra compensam a crise de preços agrícolas com ganhos imobiliários, determinando que parte de suas propriedades sejam loteadas e transformadas em assentamentos urbanos em áreas de grande valorização. Obviamente que para compensar o lucro da atividade agroexportadora esses novos núcleos urbanizados são

\footnotetext{
${ }^{32}$ Urban expansion inevitably covers some agricultural land while changes in land values and land markets around cities often result in land left vacant as the owners anticipate the gains they will make from selling it or using it for non-agricultural uses. In most urban areas in low-and middle-income nations, the absence of any land-use plan or strategic planning framework to guide land-use changes means that urban areas expand haphazardly. This expansion is determined by where different households, enterprises and public sector activities locate and build, legally or illegally. In most instances, there is little effective control over land-use conversions from agriculture to non-agricultural uses.
} 
destinados às classes mais altas, criando assim um pacto de gestão entre o latifúndio, as empreiteiras e a administração pública.

Inclusive, não é difícil encontrar situação em que o grande proprietário e o administrador público são a mesma pessoa, consubstanciando o interesse da sua classe através da máquina municipal. Paula Santoro (2012, p. 257), ao analisar o caso de Catanduva -SP, constatou que elite agrária local, entrenhada nos principais cargos políticos do município, se utilizava de informação privilegiada sobre estradas regionais a serem abertas ou duplicadas, bem como percebeu direcionamento ou lobby para que determinadas estradas sejam objeto de investimentos estaduais. Segundo a pesquisa, os proprietários de terras no entorno da cidade, não só visavam a valorizar suas terras mirando uma eventual urbanização, como também arquitetavam todo o processo para servir como moeda de troca de apoios eleitorais, nas suas diferentes formas (afinal, estariam envolvidos desde poderosos agentes estaduais até empreiteiras e concessionárias de pedágio, criando um verdadeiro caldeirão político "intra-elite", maximizando lucros e mantendo as estruturas de poder)

Além disso, a perda de produtividade agrícola "solucionada" com empreendimentos imobiliários vem sendo feita através de relações ainda patrimonialistas com a agroindústria, o que mostra sinais de migração de capital produtivo para o ativo terra (reforçando a tendência de financeirização do solo descritos por Harvey (2005); Royer (2013); Rolnik (2015), o que pode agravar a concentração fundiária e de renda no país, com grande impacto sobre a forma de expansão das cidades. Nesse sentido, Santoro (2012, p. 217) analisa empiricamente a situação de diferentes municípios do interior paulista e expõe:

\footnotetext{
Sem cruzar os dados de produtividade, é perceptível em alguns municípios cuja produtividade agroexportadora de cana-de-açúcar é alta que o crescimento urbano dá-se por contiguidade e tem um limite muito evidente. Assim que termina a cidade, inicia-se o plantio de cana. $\mathrm{O}$ estudo de caso sobre o município de Catanduva ilustra bem esta hipótese. Ou mesmo, se compararmos a forma de crescimento dos clássicos municípios produtores de cana do Noroeste Paulista ex. Monte Alto ou Bebedouro (além de Catanduva) com município onde a produção agrícola declinou, como Limeira, cuja produção de laranja está diminuindo; ou como Mairiporã, estância climática onde o turismo impera, vê-se ocupações mais dispersas no território, sem contiguidade
}

Graziano da Silva (1997b, p.13) também enxerga relação entre o desempenho das commodities da agroindústria e a dinâmica de expansão sobre o espaço rural. $\mathrm{O}$ autor traça um paralelo entre o preço do suco de laranja, café e grãos e o do valor dos imóveis rurais, concluindo que ambos se influenciam de maneira inversamente proporcional.Além disso, o autor argumenta que a produção agrícola vem ocupando cada vez menos o tempo total de 
trabalho das famílias rurais e, portanto, a agricultura vem respondendo apenas por parte do tempo de ocupação e da renda dessas famílias. Sendo assim, as atividades agropecuárias já não respondem pela maior parte da renda da população rural (GRAZIANO DA SILVA, 1999)

Graziano da Silva (1997b) enxerga que está cada vez mais difícil delimitar o que é rural e o que é urbano nas cidades brasileiras, vez que há atividade industrial no campo, há atividade agrícola dentro das cidades e que isso de fato não deve ser uma preocupação. Para o autor , o meio rural pode ser entendido como um "continuum " do urbano do ponto de vista espacial e, como resultado desse processo dialético de transformação, a agricultura tradicionalmente caracterizada como um setor produtivo hermético, com seu próprio mercado de trabalho e equilíbrio interno, se integrou no restante da economia a ponto de ser impossível uma cisão. Graziano da Silva descreve esse amálgama rururbano como responsáveis pelo surgimento dos “complexos agro-industriais, com dinâmicas urbanísticas muito peculiares. Dessa forma, uma vez que a zona rural hoje comporta funções muito mais complexas e com impactos muito determinantes no perfil da expansão da cidade, não parecem satisfatória a regulação simplista desse espaço, incoerente com sua nova realidade.

Outro aspecto a se considerar é sobre o fato de que os centros urbanos geralmente se expandem sobre a terra agrícola mais produtiva do país, já que grande parte dos centros urbanos cresceu precisamente por conta da alta produtividade do solo - seja para alimentar a população em crescimento, seja por alguma atividade econômica vinculada ao uso da terra (SATTERTHWAITE et al., 2010, p. 2816) Hoje, entretanto, obviamente os grandes aglomerados urbanos demandam uma quantidade de recursos muito maior que seus arredores são capazes de fornecer, tanto pela especlialização da mão de obra em serviços e indústria, pelo tamanho das populações quenato pelo esgotamento do solo local. Dessa forma, as cidades modernas muitas vezes ocupam terras agricultáveis e se baseiam em grandes e complexas cadeias de suprimentos globais, o que significa um modelo de organização espacial extremamente custoso financeiramente e ecologicamente. Além disso, a dependência desses núcleos urbanos centralizados torna as populações vulneráveis a desastres tanto nas regiões que produzem seus recursos como na própria localidade, o que gera grande insegurança e flutuação de preço. (SATTERTHWAITE et al., 2010, p. 2816) 
Levando em consideração os novos conceitos de zona urban e rural, que rompem com a dicotomia até então consolidada de cidade x fazenda, é possível vislumbrar a harmonização das atividade agrícolas em uma nova conformação da organização territorial, possivelmente ajudando as cidades a se tornarem mais auto-sustentáveis, resilientes e menos suscetíveis às adversidades do comércio de recursos essenciais. Sem contar que um novo jeito de pensar a zona rural finaldade colocaria a região no foto dos debates, tirandoa da obsolescência funcional, sempre tratada como reserva de terra para o mercado imobiliário. Satterthwaite (et al., 2010, p. 2816-2817) elucida que hoje já existem Centenas de milhões de habitantes urbanos que dependem da agricultura urbana por parte de seu consumo ou renda de alimentos, pois vendem culturas de alto valor ou culturas não alimentares ou criam gado para venda. Uma série de estudos em centros urbanos na África Oriental durante a década de 1990 mostraram 17-36\% da população cultivando e / ou mantendo gado (Lee-Smith 2010). Esses estudos também mostraram a diversidade entre os agricultores urbanos, que vão desde profissionais liberais de alta instrução até faixas mais pobres, à base de subsitência. Em Dar es Salaam, na Tanzânia, a agricultura urbana e periurbana teve um papel importante na segurança alimentar e nutricional, assim como acontece em grande parte das nações de baixa renda. Entretanto, conforme o espaço se torna cada vez mais financeirizado e disputado pela capilaridade de investimentos, se torna cada vez mais difícil para os pobres urbanos ter acesso à terra necessária para a agricultura (Smit et al., 1996; Lee-Smith 2010).

\subsection{Efeitos sobre os Bens Públicos}

O processo de redemocratização na década de 1980 foi acompanhado por importantes transformações políticas e demográficas no ambiente urbano e rural. As grandes cidades começam a se desconcentrar em direção ao interior, incentivadas pela piora nas condições de vida nas grandes cidades, pela dispersão do parque industrial e ao surgimento de novas formas condominiais de urbanização. Na região centro-sul, especialmente no Estado de São Paulo, esse processo se deu com mais intensidade em função da capacidade produtiva já instalada, da rede de infraestruturas consolidada, do alto poder aquisitivo da população e, por fim, pelas mudanças no financiamento habitacional vivida nos anos 2000.

Além disso, a oscilação nos preços das commodities produzidas no interior tornava os negócio imobiliários uma alternativa interessante tanto para os agroempresários quanto para as prefeituras, o que resultou em pouca resistência à mudança de uso rural para urbano. (Santoro \& Bonduki, 2009) Vale lembrar que o período foi acompanhado por grandes 
investimentos no sistema rodoviário, firmando o modal de transporte automobilístico individual como o principal (quando não o único disponível), abrindo novos corredores de “colonização”. Todas essas facilidades econômicas atraíram o interesse de imobiliárias, que enxergaram um lucrativo potencial de expansão (SANTORO, 2012, p.27)

. A partir desse momento o perfil geográfico das classes sociais sofre alteração e as burguesias metropolitanas, que antes se concentravam em bairros-jardins nas regiões centrais, começam a se mudar para os novos espaços planejados e exclusivos na zona rural. Da mesma, forma as camadas médias também se dispersam para além do perímetro urbano, principalmente em condomínios verticais (BNH; RMV e afins), mas em regiões ainda bem conectadas à malha urbana. (SANTORO, 2012, p. 68-69). Interessante notar a posição dos Shopping Centers como "âncoras" de serviços e lazer nesse processo de colonização de novos espaços, arrastando as novas centralidades para perto da zona rica de expansão (REIS, 2006, p.12). Por fim, as classes mais baixas são relegadas às periferias, preteridas nos investimentos públicos de toda sorte, e geralmente se fixam em regiões diametralmente opostas dos setores com postos de trabalho e serviços, gerando grande demanda por transporte público. (SANTORO, 2012). Além de não usufruírem igualmente da valorização imobiliária produzida pelos agentes públicos, a população periférica precisa gastar cada vez mais com mobilidade (e torcer para que as empresas de transporte não sejam cartelizadas, como é comum acontecer).

Sposito (2013) descreve que o processo de diferenciação socioespacial na cidade se dá tanto pela segregação quanto pela autosegregação. No primeiro caso, enquadram-se as pessoas pobres que são empurradas para as periferias sem participar do planejamento da cidade. Já no segundo, enquadram-se as pessoas mais ricas que optam pelo isolamento em relação ao conjunto da comunidade. “(...)é o espaço dos outros e, portanto, não mais de todos" (SPOSITO, 2013, p.281). É importante lembrar que os empreendimentos imobiliários não são integralmente responsáveis por criar essa necessidade que a elite tem de diferenciar-se social e espacialmente do "resto", afinal, isso é fruto de uma mentalidade colonial histórica ainda enraizada na sociedade. Entretanto, os empreendedores imobiliários se aproveitam da existência de extremos de valorização entre as regiões urbanas, lucrando ainda mais e reforçando a privatização financeirizada do território. (SPOSITO, 2003, p. 1) Paula Santoro (2012, p. 144), elucida que esse processo se mantêm e se reproduz pelo deslocamento da externalidade de vizinhança, ou seja, mantendo a distinção espacial em favor dos padrões desiguais de valorização entre as partes ricas e pobres. Sendo assim, como há muitos espaços desvalorizados, os poucos espaços servidos 
de investimentos se tornam ainda mais disputados e, portanto, ainda mais caros (e lucrativos). São verdadeiros enclaves de habitabilidade.

Essa nova modalidade de organização urbana acaba influenciando diretamente nas formas como a população utiliza os seus espaços coletivos, assim como influencia na regulação dos bens públicos. "A produção dos espaços públicos gera uma demarcação física nas cidades, estas delimitações definem usos e funções, além de também constituírem uma fronteira simbólica para a cidade" (LEONELLI, 2017, p.3)

\subsubsection{Loteamentos fechados:}

O loteamento é uma das modalidades de parcelamento do solo admitidas pela lei 6766 de $1979\left(\operatorname{art.} 2^{\circ}\right)^{33}$. Justamente por conceder parte da atividade urbanizadora ao setor privado, o legislador estabeleceu alguns critérios legais mínimos para impedir que o interesse público fosse completamente dominado pelo particular, evitando a privatização dos espaços e dos bens coletivos. É o que se percebe em determinados requisitos do dispositivo:

a) As áreas destinadas a sistemas de circulação, a implantação de equipamento urbano e comunitário, bem como a espaços livres de uso público, serão proporcionais à densidade de ocupação prevista pelo plano diretor ou aprovada por lei municipal para a zona em que se situem (art. $4^{\circ}$ - I)

b) ; Consideram-se comunitários os equipamentos públicos de educação, cultura, saúde, lazer e similares. (art. $\left.4^{\circ}-\mathrm{IV}, \S 2^{\circ}\right)$,

c) O Poder Público competente poderá complementarmente exigir, em cada loteamento, a reserva de faixa non aedificandi destinada a equipamentos; Consideram-se urbanos os equipamentos públicos de abastecimento de água, serviços de esgotos, energia elétrica, coletas de águas pluviais, rede telefônica e gás canalizado. $\left(\operatorname{art} .5^{\circ}\right)$

\footnotetext{
${ }^{33}$ Art. $2^{\circ}$. O parcelamento do solo urbano poderá ser feito mediante loteamento ou desmembramento, observadas as disposições desta Lei e as das legislações estaduais e municipais pertinentes. $1^{\circ}$ - Considerase loteamento a subdivisão de gleba em lotes destinados a edificação, com abertura de novas vias de circulação, de logradouros públicos ou prolongamento, modificação ou ampliação das vias existentes.§ $2^{\circ}$ considera-se desmembramento a subdivisão de gleba em lotes destinados a edificação, com aproveitamento do sistema viário existente, desde que não implique na abertura de novas vias e logradouros públicos, nem no prolongamento, modificação ou ampliação dos já existentes.
} 
d) Antes da elaboração do projeto de loteamento, o interessado deverá solicitar à Prefeitura Municipal, ou ao Distrito Federal quando for o caso, que defina as diretrizes para o uso do solo, traçado dos lotes, do sistema viário, dos espaços livres e das áreas reservadas para equipamento urbano e comunitário, apresentando, para este fim, requerimento e planta do imóvel contendo, pelo menos: IV - a indicação dos arruamentos contíguos a todo o perímetro, a localização das vias de comunicação, das áreas livres, dos equipamentos urbanos e comunitários existentes no local ou em suas adjacências, com as respectivas distâncias da área a ser loteada; $\left(\operatorname{art} .6^{\circ}\right)$

e) A indicação das áreas públicas que passarão ao domínio do município no ato de registro do loteamento. (art. $\left.9^{\circ}, \S 2^{\circ} \mathrm{III}\right)$

f) A enumeração dos equipamentos urbanos, comunitários e dos serviços públicos ou de utilidade pública, já existentes no loteamento e adjacências. (art. $9^{\circ}, \S 2^{\circ}$ IV)

g) Desde a data de registro do loteamento, passam a integrar o domínio do Município as vias e praças, os espaços livres e as áreas destinadas a edifícios públicos e outros equipamentos urbanos, constantes do projeto e do memorial descritivo (art. 22)

É notável, portanto, que as áreas internas do loteamento, destinadas à afetação ao interesse público ou para a satisfação de um bem geral da comunidade, passam a integrar o patrimônio público do Município, ficando gravados de indisponibilidade. Entretanto, a lei federal apenas é competente para estabelecer diretrizes gerais nesse aspecto, caso contrário estaria interferindo em competência urbanística dos municípios. Dessa forma, fica a cargo dos municípios regular as especificidades organizacionais do uso do solo e isso nem sempre acontece, comprometendo a efetividade das políticas urbanas (é comum negligência nas diretrizes de expansão viária, por exemplo). Justamente por isso, Paula Santoro (2012, p. 102) ressalva que muitos técnicos da prefeitura acabam aprovando os projetos enviados sem respeitar os critérios estabelecidos, o que diminui o controle sobre os espaços públicos. (É evidente que o empresariado se utiliza de lobby e outros meios escusos para conseguir flexibilizar a lei em seu proveito. Mas, a princípio, atenhamo-nos à questão administrativa).

Outro problema recorrente em relação aos loteamentos é, justamente, a modalidade "fechada". Ainda que o projeto do empreendimento seja legal regular e contemple áreas 
destinadas ao uso coletivo e, portanto, ao domínio público municipal, é comum os administradores do empreendimento fecharem o acesso do loteamento com cancela e guarita depois de pronto, privatizando o espaço. O empresário tem consciência de que uma gleba de terra, inicialmente privada, ao ser parcelada num loteamento, passa a ter áreas privadas e áreas públicas integrantes da malha urbana da cidade e com acesso irrestrito. (ROCHA, 2011, p. 3) Justamente por isso, José Afonso da Silva constata que não existe embasamento legal na modalidade de loteamento fechado, sendo artifício de especuladores para maximizar seus proveitos econômicos:

"Não há legislação que os ampare, constituem uma distorção e uma deformação de duas instituições jurídicas: do aproveitamento condominial de espaço e do loteamento ou do desmembramento. É mais uma técnica de especulação imobiliária, sem as limitações, as obrigações e os ônus que o direito urbanístico impõe aos arruadores e loteadores do solo . (1981, p. 353)

Ainda, Hely Lopes Meirelles (1994) identifica os espaços livres e áreas verdes nos loteamentos como limitações do traçado urbano voltadas à salubridade da cidade Paulo Affonso Leme Machado (2000) acentua nas praças seu caráter sanitário, como elemento de direito urbanístico e instrumento de proteção à saúde e José Afonso Da Silva (1994) lembra que elas se prestam a exercitar o direito de reunião (art. $5^{\circ}$, II, XVI, XX, CF), para fins religiosos, cívicos, políticos e recreativos. Sendo assim, existe uma série de direitos coletivos que são comprometidos pela construção de loteamentos fechados. Além de ilegais, a recorrência dessa modalidade nos processos de expansão urbana é, ao mesmo tempo, um processo de privatização do espaço público, antagônico ao direito à cidade.

\subsubsection{Condomínios horizontais}

Como o próprio nome diz, os condomínios não ensejam a criação de lotes individualizados como no loteamento mas, aproximam-se mais da situação em "a mesma coisa pertence a mais de uma pessoa, cabendo a cada uma delas igual direito, idealmente, sobre o todo e cada uma das partes". (PEREIRA, 2009, p. 160). No contexto urbanístico, o condomínio especial de casas térreas e assobradadas (condomínio residencial) é a modalidade de uso e ocupação do solo que consiste na construção edificada em plano horizontal, sendo disciplinada pela Lei Federal de n. 4.591/64, "As unidades residenciais têm acesso privativo apenas a áreas de uso comum dos condôminos, que incluem, dentre outras, a malha viária interna ao empreendimento, bem como as áreas comuns, como salão de jogos e de festas, guaritas, corredores" (ROCHA, 2011, p. 3): 
Ainda que a lei 4.591/64 estabeleça critérios para definição de unidades autônomas o que acontece, na realidade, é a comercialização de lotes tal como num loteamento e não de frações ideais, como nos condomínios verticais. Os empreendedores se utilizam erroneamente da legislação, destinada à regulação de prédios de apartamentos e casas assobradadas, para justificar a transformação de bairros inteiros em enclaves de exclusividade, se desvencilhando das obrigações coletivas impostas pela lei 6.766 de 1979 (ANDRADE, 2006). Sendo assim, através de interpretações forçosas da lei, essa modalidade de ocupação do solo avança sobre a zona rural de maneira dispersa "feudalizando" o território. A conivência do poder público se dá de várias formas, desde autorizando projetos nesses moldes até, principalmente, flexibilizando a lei de perímetro urbano permitindo acesso às terras rurais mais baratas (SANTORO, 2012).

\subsection{3. (Breve) Classificação dos Bens Públicos}

É importante considerar as reflexões acerca dos bens no contexto dos loteamentos e condomínios para então se fazer uma análise crítica do tipo de cidade que se constrói e que tipo de regulação deve recair sobre ela. A recente fusão entre conceito de público e privado suscita diversos questionamentos, tanto por parte de quem usa quanto de quem administra os espaços urbanos. (Afinal, um "bairro privado" é parte integrante da cidade? A rua privada do condomínio tem função pública? O regime jurídico que regula esses bens deve se aproximar mais do modelo privatista ou publicístico?) Ainda, questiona-se o quanto essa nova conformação territorial está em acordo com os princípios constitucionais e doutrinários no que diz respeito à regulação dos bens, com consideráveis impactos à ordem econômica e social.

Para classificar os bens sob sua jurisdição, o direito positivado brasileiro utiliza como critério a titularidade, sendo públicos os bens do domínio nacional pertencentes ás pessoas jurídicas de direito público interno, conforme elencados no art. 98 e 41 do código civil (MARRARA, 2007):

Art. 98. São públicos os bens do domínio nacional pertencentes às pessoas jurídicas de direito público interno; todos os outros são particulares, seja qual for a pessoa a que pertencerem.

Art. 41. São pessoas jurídicas de direito público interno:

I - a União;

II - os Estados, o Distrito Federal e os Territórios;

III - os Municípios;

IV - as autarquias;

IV - as autarquias, inclusive as associações públicas; (Redação dada pela Lei ${ }^{\circ}$ 11.107, de 2005)

$\mathrm{V}$ - as demais entidades de caráter público criadas por lei. 
Parágrafo único. Salvo disposição em contrário, as pessoas jurídicas de direito público, a que se tenha dado estrutura de direito privado, regem-se, no que couber, quanto ao seu funcionamento, pelas normas deste Código.

Parágrafo único. Salvo disposição em contrário, as pessoas jurídicas de direito público, a que se tenha dado estrutura de direito privado, regem-se, no que couber, quanto ao seu funcionamento, pelas normas deste Código. (BRASIL, 2002)

Por sua vez, o art. 99 do Código Civil diferencia esses bens públicos em três grupos por um critério de afetação, sendo a) primeiro, bens de uso comum do povo (ou domínio público), caracterizados por uma sujeição precípua ao uso indistinto de todos, afetados por lei ou ato administrativo visando à satisfação direta de interesses privados, coletivos e individuais, e públicos, primários e secundários (MARRARA, 2007, p. 60). Neles se enquadram os bens que podem ser utilizados por todos, em igualdade de condições, seja por determinação legal, seja em razão de usa natureza física, como praias, ruas, praças e etc. (DI PIETRO, 2004, p. 569);

b) segundo, bens de uso especial (ou bens patrimoniais indisponíveis), definidos como instrumentos necessários à prestação de serviços públicos. Englobam, assim, os bens afetados a um estabelecimento ou serviço público e, portanto, seus beneficiários seriam os servidores e/ou os utentes dos serviços estatais (MARRARA, 2007, p. 61). Nesse caso há uma vinculação jurídica necessária entre o bem e o serviço público que se presta, por exemplo um prédio afetado para a constituição de uma faculdade estadual.

c) terceiro, por fim, os bens dominicais, que não integram o “domínio público" em função de sua desafetação. Esses bens não teriam destinação pública determinada, nem fins administrativos, podendo ser utilizados pelas pessoas jurídicas de direito público competentes em qualquer ocasião, além de poderem ser alienados. (MARRARA, 2007, p. 64)

Entretanto, essa classificação tem se mostrado insatisfatória para regular a complexidade de relações jurídicas envolvendo os bens, extrapolando a dicotomia publicoprivado. $\mathrm{O}$ critério da titularidade não permite que se identifique um regime jurídico padrão aplicável adequadamente a todas as três espécies de bens públicos. Para Thiago Marrara (2007, p. 55), “ o critério da titularidade, pública ou privada, não decorre necessariamente de um regime, público ou privado". Por exemplo, por mais que os bens dominicais não possuam uma atribuição pública específica ainda se vinculam constitucionalmente pelo princípio da função social da propriedade, o que resguardaria um resquício de utilidade pública do bem. Ou, também, há dificuldade em encaixar nos três critérios os bens de empresas estatais e bens de entes públicos com estrutura privada. Para Carlos Ari Sundfeld 
"não tem valor constitucional a aplicação do direito privado às empresas estatais prestadoras de serviço público. Em relação às prestadoras de atividades econômicas, se aplica o regime privatístico, porém, não as dispensa das sujeições típicas da administração" (SUNDFELD, 1995, p. 1995 apud MARRARA, 2007, p. 77)

No contexto urbanístico essa problemática se ilustraria, por exemplo, no questionamento sobre o acesso aos bens internos dos condomínios horizontais. Afinal, as vias, as praças, os bosques internos a esses bairros privados ocupam área considerável da cidade e possuem função eminentemente coletiva. Pelo critério da titularidade esses bens estariam no mesmo locus jurídico de um lote individualizado na periferia, sujeitos, portanto, a um mesmo regime jurídico (Privado). Entretanto, pelo princípio da função social da propriedade, não seria cabível a privatização de regiões inteiras da cidade para satisfazer as demandas de uma fatia muito específica do estrato social. É justamente por conta dessa dificuldade de coesão jurídica que alguns doutrinadores introduziram uma nova sistematização à matéria, flexibilizando as regras engessadas do Código Civil na tentativa de superar seu enfoque personalista-patrimonialista: a teoria do domínio público.

\subsubsection{Teoria do Domínio Público}

A teoria do domínio público propõe uma visão mais funcional dos bens na sociedade, pautando a regulação muito mais pela utilidade desses bens (se mais ou menos pública) do que necessariamente por quem detém os títulos de propriedade (sem se olvidar do princípio da indisponibilidade conformado pelas regras de inalienabilidade, impenhorabilidade e imprescritibilidade). Com base nisso, é proposta uma escala de dominialidade, a qual se assenta em dois pressupostos: 1 . Nem todos os bens públicos estão em regime publicístico puro, uma vez que alguns deles entram teoricamente em regime privado apenas em parte derrogado pelo direito público; 2 . Nem todos os bens particulares, bens pertencentes a pessoas jurídicas de direito privado, estão imunes à incidência de um regime mais publicístico que afasta o regime privado natural - esse bastante útil à defesa do acesso à cidade frente à "condominialização" do território. (MARRARA, 2007, p. 9194)

Dessa forma, o domínio público estatal corresponderia ao primeiro conjunto de bens, abarcando bens públicos agravados por um regime publicístico puro (bens de uso comum do povo e bens de uso especial). Os dominicais, entretanto, por mais que estejam sob a incidência de muitas normas públicas, se enquadrariam no domínio privado do Estado, sendo regidos por um regime mais próximo daquele que incide sobre os bens particulares. Em relação ao segundo pressuposto apresentado, estariam os bens das empresas, estatais 
ou não, prestadoras de serviços públicos típicos do Estado e os bens privados utilizados pela Administração Direta para realização de funções públicas (São bens que com funções similares às que constituem o domínio público, mas que não são próprias do Estado). Os bens privados que exercem funções públicas seriam classificados como domínio público imprório, justamente pela falta de natureza jurídica de direito público. (MARRARA, 2007, p.95) Com base nisso, ainda que as novas formas de ocupação do espaço privatizem o território urbano, é possível contra argumentar sobre a pretensão de exclusividade. Um condomínio, por exemplo, seria avaliado pela sua função dentro do tecido urbano e não por sua titularidade (até porque, mesmo sua titularidade não possui embasamento nos critérios positivados vigentes). O mesmo serve para atacar a segregação de cunho classista e racista de alguns estabelecimentos privados com função eminentemente públicas, como shoppings e restaurantes, no caso dos rolezinhos. A teoria do domínio público, portanto, pode ser uma alternativa para a recuperação função pública, tão vulnerada em tempos de camarotização.

Tabela 3 - Escala de Dominialidade

\begin{tabular}{|c|c|c|c|}
\hline \multicolumn{4}{|c|}{ Escala de Dominialidade } \\
\hline Objeto & Natureza Jurídica & $\begin{array}{c}\text { Funções Sociais } \\
\text { (FS) }\end{array}$ & Regime Jurídico \\
\hline $\begin{array}{l}\text { 1. Domínio } \\
\text { público } \\
\text { estatal }\end{array}$ & $\begin{array}{l}\text { Propriedade } \\
\text { estatal }\end{array}$ & $\begin{array}{l}\text { FS da propriedade } \\
\text { FS do domínio } \\
\text { público } \\
\text { FS dos bens } \\
\text { públicos } \\
\text { FS específicas }\end{array}$ & $\begin{array}{l}\text { Regime jurídico } \\
\text { publicístico }\end{array}$ \\
\hline $\begin{array}{l}\text { 2. Domínio } \\
\text { público } \\
\text { impróprio }\end{array}$ & $\begin{array}{l}\text { Propriedade } \\
\text { particular }\end{array}$ & $\begin{array}{l}\text { FS da propriedade } \\
\text { FS do domínio } \\
\text { público } \\
\text { FS específicas }\end{array}$ & $\begin{array}{l}\text { Regime jurídico } \\
\text { predominantemente } \\
\text { publicístico }\end{array}$ \\
\hline $\begin{array}{l}\text { 3. Domínio } \\
\text { privado } \\
\text { estatal ou } \\
\text { bens } \\
\text { dominicias }\end{array}$ & $\begin{array}{l}\text { Propriedade } \\
\text { estatal }\end{array}$ & $\begin{array}{l}\text { FS da propriedade } \\
\text { FS do domínio } \\
\text { público } \\
\text { FS específicas }\end{array}$ & $\begin{array}{lr}\text { Regime jurídico } \\
\text { privado } \\
\text { derrogações } \\
\text { direito público }\end{array}$ \\
\hline
\end{tabular}




\begin{tabular}{l|l|l|l}
\hline $\begin{array}{l}\text { Domínio particular } \\
\text { ou bens particulares }\end{array}$ & $\begin{array}{l}\text { Propriedade } \\
\text { particular }\end{array}$ & $\begin{array}{l}\text { FS da propriedade } \\
\text { FS específicas }\end{array}$ & $\begin{array}{l}\text { Regime jurídico } \\
\text { essencoalmente } \\
\text { privado }\end{array}$ \\
\hline
\end{tabular}

Fonte: MARRARA, 2007, p. 96 


\section{ANÁliSE DE CASO: A ORGANIZAÇÃo TERRITORIAL DE RIBEIRÃo PRETO}

\subsection{Ribeirão Preto no Período Colonial: expansão e primeiros regramentos}

O que se chama hoje de região de ribeirão preto é a porção do território que se localizava próxima ao "caminho de goiás" (São Paulo, Campinas, Mogi-Mirim, Casa Branca, Batatais e Franca). Com a decadência da mineração entre os fins do século XVIII e início do século XIX, essa região passa a receber um grande afluxo de mineiros. Enquanto a região de campinas passa a se dedicar à produção e ao processamento da cana de açúcar, os pontos mais distantes se dedicam a criação de animais e a cultivos de subsistência. (PIRES, M.C.S, 1996, 23). Nas três primeiras décadas do século XIX a região de Ribeirão Preto se constituía em três núcleos populacionais em São Simão, Cajuru e Jaboticabal, pertencentes a Casa Branca, Batatais e Araraquara, respectivamente. Todos constituídos através da doação de terras para a constituição de um patrimônio religioso (Como mencionado no tópico anterior, era esse o primeiro passo para a formação e institucionalização de um núcleo urbano)

As terras do patrimônio de São Sebastião de Ribeirão Preto estavam subordinadas ao Juiz da Comarca de Casa Branca, que "solicitava ao fabriqueiro todo zelo e vigilância em relação às terras doadas: abertura de ruas conforme as instruções urbanísticas da época e, o levantamento dos edifícios que deverão ser de 18 palmos de pé direito, todos alinhados e distribuídos em regra sem de 60 palmos de largura" (REIS, 1979, p.9 apud PIRES, 1996, p. 37). A estrada de ferro Santos-Jundiaí (1867) facilitou o acesso à região, que sentiu aumento da ocupação e foi elevada à categoria de freguesia em 1870, e à Vila em 1871, desmembrando-se de São Simão (PIRES, 1996, p. 38). Logo em seguida a Câmara Municipal da cidade é construída em 1874, administrando os seus 5.535 habitantes.

De acordo com Maria C. Pires, (1996, p. 38) " o traçado ortogonal, comum ao urbanismo de topógrafo, que marcou a paisagem das cidades do período cafeeiro, indicava, também, pela dimensão das ruas e da praça, uma preocupação em criar um espaço central já prevendo uma expansão considerável do núcleo urbano" - sem contar os motivos já explicitados por Raquel Rolnik, sobre a conveniência que esse traçado propiciava quando da necessidade de individualizar lotes e vende-los. Importante salientar que grande expansão do café na região, ocorrida entre 1876 e 1883, foi impulsionada pela construção da malha ferroviária, o que aumentou a ocupação das terras no município e, consequentemente, a aglomeração e valorização em torno do setor urbano em formação. 
Em 1878, a recém construída câmara municipal propôs um vasto Código de Posturas concernentes à organização do espaço e da expansão de novas vias, mas era pendente de aprovação da Assembléia Provincial de São Paulo. (Segundo Maria Conceição Pires, esse código era o único instrumento de que dispunha a administração local para estabelecer normas em sua área de competência - 1996, p.40). A lei foi aprovada e publicada em 1883 e passou a regular, além do traçado de expansão, sobre a qualidade construtiva e estética das edificações no perímetro urbano:

\section{RESOLUÇÃO N. 48 de 1883}

O visconde de Itú vice-presidente da provincia de S. Paulo etc. Faço saber a todos os habitantes que a assembléa legislativa provincial, sob proposta da camara municipal da villa do Ribeirão Preto decretou a resolução seguinte: (...)

Art. 139. - Os terrenos para concessão de datas dentro do perimetro da decima urbana, para construcção de casa, quintaes, pomares, jardins, etc., serão requeridos ao presidente da camara, e, quando deferidas as respectivas petições, serão ellas em synopsis registradas em livro especial pelo secretario da camara; não podendo sem que tenha sido cumprido esse preceito o arruador fazer ou demarcar o alinhamento e seguirem-se as mais formalidades.

Para Pires (1996, p. 40) as proibições não valiam para toda a cidade mas, como será analisado posteriormente, atingiam apenas o espaço destinado à burguesia cafeeira. Além disso, a autora evidencia que a destinação de terrenos para a construção de moradias era uma das formas encontradas por esse grupo social dominante para iniciar o processo de constituição do núcleo urbano, o que prometia grande utilidade para seus negócios. Pelo artigo 139 exposto acima, muito embora perceba-se uma preocupação com a organização do traçado urbano, diferente da origem de muitas cidades brasileiras, denota-se o forte controle da oligarquia agrária sobre o acesso às terras da então Villa, bem como o interesse econômico em controlar sua expansão tendo em vista o aumento populacional.

Pelos dados da secretaria de Agricultura, Commercio e Obras Públicas (Estatísticas Agrícolas e Zootécnica do Estado no anno de 1904-1905, São Paulo, Typ. Brazil), em 1905 os três maiores proprietários de terras em Ribeirão Preto eram Francisco Schimidt, Martinho Prado e a Cia. Agrícola Fazenda Dumont concentravam 35\% da área do município e $31,3 \%$ da produção. Esses mesmos três proprietários concentravam $57,1 \%$ das terras e $51,3 \%$ da produção de Sertãozinho. 
Maria Conceição Pires (1996, p. 43) salienta que a concentração de terra, somada à intensa ocupação da mão-obra livre e escrava pelos grandes latifúndios, deixava inclusive poucos espaços disponíveis para o cultivo de alimentos. Com isso, a própria expansão da cidade de Ribeirão Preto se "comprometeu" devido à escassez de mantimentos (a população entre 1874 e 1886 passou de 5.535 habitantes para 10.420 - o que, segundo a autora, havia demanda para crescimento maior não fosse a crise de abastecimento).

É importante, também, destacar o período como transição da mão de obra escrava para a mão de obra assalariada imigrante. Ainda que de maneira fragmentada ${ }^{34}$, a entrada do Brasil no capitalismo global foi acompanhada de um projeto de nação inspirado nas grandes potências globais europeias, o que se refletia tanto na arquiteturas das cidades (vide reformas neoclássicas de inspiração francesa no Rio de Janeiro) quanto nas políticas de embranquecimento da população, tendo a oligarquia cafeeira financiado boa parte da vinda de estrangeiros italianos, alemães, espanhóis para o Brasil. Foi a partir desta década (1880) que se efetivaram os investimentos de parte do excedente obtido com o café na cidade, preparando-a para receber um novo perfil de cidadão, num novo perfil de sociedade (capitalista, europeizada).

Davescovi (1985, p. 30) destaca o efeito urbanizado do café quando cita que "o processo inicial de constituição e urbanização de cidades no Estado de São Paulo, bem como o de estruturação e consolidação de sua rede urbana, foi em muito relacionada coma uma dinâmica de internalização do capitalismo, de generalização da mercadoria, exatamente no momento em que a atividade condutora da economia do país era a produção e a comercialização do café”. Pela primeira vez uma parte robusta da riqueza gerada pela atividade econômica permanecia no território de origem ou sendo investida em setores produtivos direta ou indiretamente rentáveis (ferrovias, equipamentos coletivos urbanos, bancos, e etc). O grande afluxo de imigrantes para as fazendas e os crescentes núcleos urbanos acabou por conferir às cidades condição básica para a formação de um mercado de trabalho.

\footnotetext{
${ }^{34}$ Raquel Rolnik, em “A cidade e a Lei” (1997, p. 23) define a Lei de Terras de 1850 como marco divisor na entrada do Brasil no sistema capitalista, justamente por transformar a terra em mercadoria. Entretanto, simultaneamente à essa transformação, houve um grande apossamento das elites agrárias nacionais de grandes porções de terras, fazendo com que o país já se inaugurasse no sistema capitalista com grandes restrições de participação das dinâmicas por parte da população mais pobre. Isto é, uma pequena parcela da população grilou boa parte das terras disponíveis, com as mais diversas titularidades (sejam terras da coroa, sejam posses religiosas, sejam terras indígenas). Logo em seguida alteraram o modo de aquisição da propriedade com preponderância da compra e da venda, limitando o grupo com possibilidades fáticas de participar dessa operação e isolando a elite agrária no estrato mais alto das classes sociais.
} 


\subsection{República Oligárquica - a era do café.}

Segundo Pires (1996, p. 50), No final da década de 1890 Ribeirão passa a contar com diversos serviços urbanos, bem como entidades estatais administrativas. Como por exemplo rede de água e esgoto pela secretaria de agricultura, comércio e obras públicas (vinculada ao Estado de São Paulo); serviço de telefonia (1898); iluminação elétrica (1899) - pela empresa Força e Luz de Ribeirão Preto, criada para fornecer eletricidade para a zona urbana e seus arrebaldes (Villa Tibério, Barracão e Villa Bonfim). Importante notar que relato na própria secretaria para a época menciona que bairros mais pobres, como o Barracão (hoje próximo à rodoviária), além de não estarem inclusos no planejamento traçado da cidade, como na região central, que cuidadosa e meticulosamente estabelecia regras de ocupação, não eram servidos pelos serviços públicos mencionados (no que se refere ao saneamento e água encanada).

Nesse período também foi fundado o núcleo colonial Antônio Prado (1887) cuja proposta era prover as fazendas da região com um "viveiro de mão-de-obra", atendendo às exigências do complexo de atividades que envolvia a produção cafeeira. (SILVA, 2002) O núcleo colonial Antônio Prado foi locado nas terras devolutas, obviamente mais baratas e sem grande utilidade econômica, que se encontravam na várzea do ribeirão Preto e do córrego Retiro. Posteriormente, no período de industrialização dos anos 1930-40, essas regiões abrigarão fábricas e vilas operárias - evidenciando a segregação espacial entre as classes sociais da cidade:

Figura 1 - Núcleo urbano principal de Ribeirão Preto e núcleo colonial Antônio Prado em 1887. 


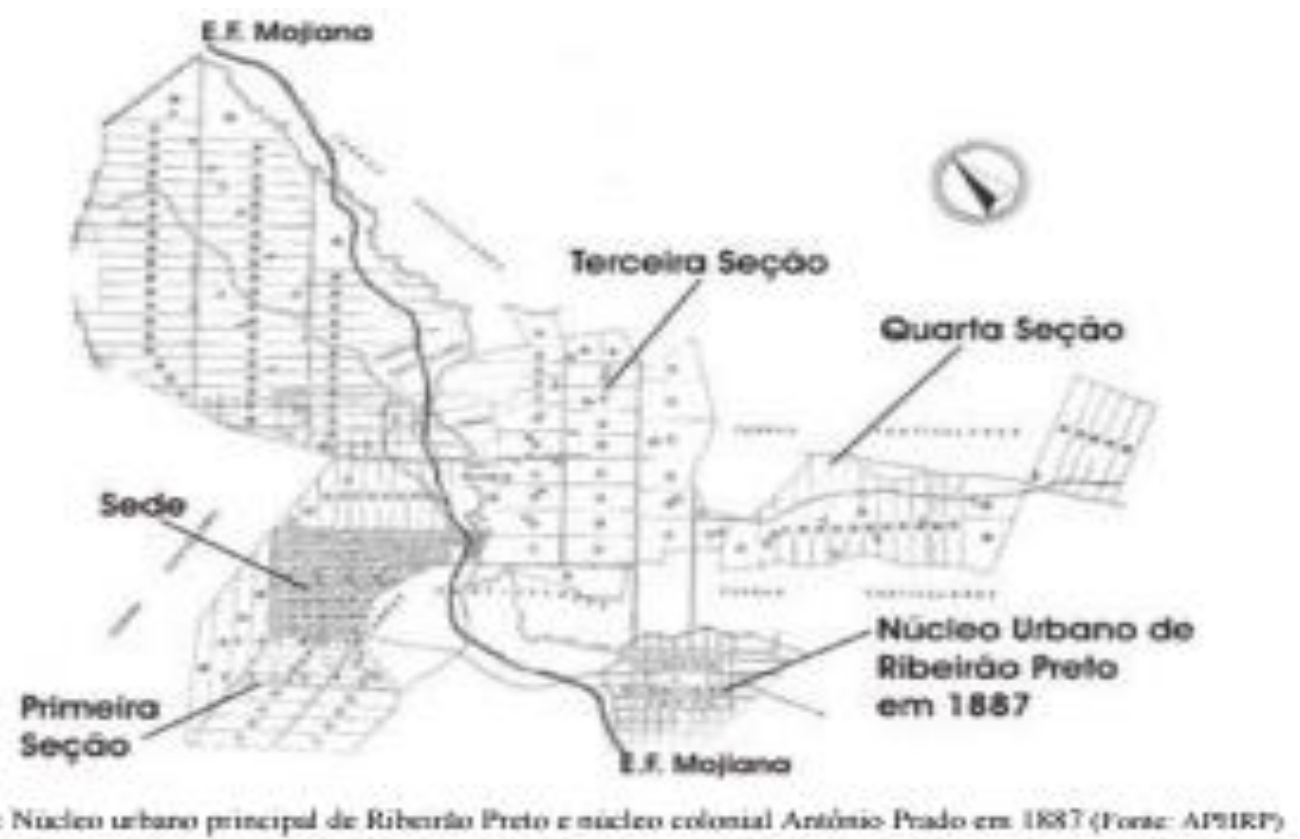

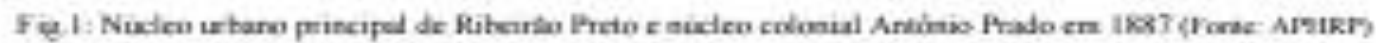

Fonte: APHRP; SILVA, 2002.

A vila Tibério, bem como bairros arredores que surgiram na década de 1890, ao lado da linha férrea, eram destino final de muitos imigrantes que chegavam pelo trem. Inclusive, em 1893, o cemitério municipal é transferido para essa região, no lote de número 16 da terceira seção do núcleo colonial Antônio Prado, sendo tirado das proximidades do quadrilátero central da cidade, região frequentada pela elite cafeeira. Curioso notar que a transferência do cemitério para bairros mais populares (tanto para a colônia Antonio Prado quanto vila Tibério) coincide com o período da epidemia de febre amarela nas cidades do interior paulista, sendo Ribeirão mais gravemente afetada em 1903 (SILVA, 2002, p. 86). Além da remoção do cemitério a região também passou a abrigar o hospital de isolamento de leprosos, o cemitério de leprosos, o matadouro municipal, a Santa Casa de Misericórdia e asilo Padre Euclides, diversos albergues, sanatórios e orfanatos, e, por fim, as fábricas (SILVA, 2002, p. 97)

Ainda que se justificassem intervenções urbanas por questões sanitárias, é evidente a utilização do poder público para afastar elementos indesejados da parte mais rica da cidade, livrando-os do risco e do contato com os "agente de contaminação" (e, consequentemente, interferindo na valorização e desvalorização de determinados setores da cidades). Nota-se aqui o poder de planejamento não só no que tange às questões técnicas do urbanismo, mas definindo tipos de cidade de acordo com as demandas do setor social dominante. Inclusive o bairro "Higienópolis", na parte mais alta do quadrilátero central, além de fazer referência ao bairro paulistano homônimo, se encaixa nesse perfil de "limpeza" em relação às demais partes da cidade. 
É possível perceber, portanto, que os bairros de migrantes e imigrantes, situados ao norte dos córregos, estavam fora do planejamento dos traçados urbanos, eram preteridos nos investimentos em serviços e infraestruturas que valorizassem o imóvel. Entretanto, ao sul dos Ribeirões o regramento urbano era meticulosamente aplicado e seu conteúdo era bastante avançado para os padrões da época. Maria Conceição Pires (1996) argumenta que a partir desse momento deflagra-se a segregação espacial Norte-Sul da cidade, que além de determinar o padrão de valorização das terras nesse eixo, evidencia uma lógica peculiar de expansão urbana, aplicada pelo poder público, muito importante para entender o histórico do perímetro urbano em momentos posteriores.

\subsubsection{Início do Século $X X$}

Ribeirão Preto inaugurou o século XX com aproximadamente 60.000 habitantes (total de 185.000 na região). As flutuações no preço do café entre 1897 e 1911, bem como geadas e secas provocaram uma mudança no perfil econômico do município, com menor dependência em relação ao café e, consequentemente, induzindo à uma maior diversificação da economia. Inclusive, destaca-se o decreto 15.803 de 1922 da presidência da república, que institui o Patronato Agrícola de Ribeirão Preto com o intuito de capacitar e fixar os imigrantes à uma função econômica na zona rural, aproveitando a mão de obra e gerando renda com pequenas propriedades rurais. Diferente das colônias estabelecidas no século XIX, o patronato não tinha intenção de produzir trabalhadores necessariamente vinculados ao café:

Decreto $n^{0} \mathbf{1 5 . 8 0 3}$, de 11 de Novembro de 1922

O Presidente da Republica dos Estados Unidos do Brasil de accôrdo com o disposto no art. 53, do Regulamento approvado pelo decreto n. 13.706, de 25 de julho de 1919

\section{DECRETA:}

Artigo unico. Fica creado no municipio de Ribeirão Preto, Estado do S. Paulo, nos predios e terrenos doados pela respectiva Camara Municipal, um Patronato Agricola, subordinado á Directoria do Serviço de Povoamento, o qual terá annexa uma estação do Monta, revogadas as disposições em contrario.

Rio de Janeiro, 11 de novembro de $1922,101^{\circ}$ da Indepedencia e $34^{\circ}$ da Republica.

EPITACIO PESSÔA.

De acordo com a pesquisadora Suelly dos Santos (2015, p. 41), esses Patronatos deveriam assumir "a transformação e o controle do espaço rural da colonização estatal, sendo visto por um duplo caráter, de assistência aos pobres e como solução policial para manter a ordem". Percebe-se, portanto, que a abertura das terras antes exclusivas para o 
café também tiveram uma motivação social já que a permanente crise econômica do período aumentou a pressão popular por melhores condições de vida e melhor distribuição do território ocupado. Destaca-se também a interferência do poder central da República na organização territorial, talvez aí denotando um enfraquecimento da oligarquia paulista nas decisões políticas.

A partir disso, ao mesmo tempo que novos habitantes conseguem fixar-se em pequenas propriedades agrícolas, muitos trabalhadores rurais do café migram para o centro urbano, que passa a ganhar maior importância e atrair maiores investimentos, como centros fabris e demais serviço correlacionados (CANO, 1977). Pires (1996, p. 54) elucida que Ribeirão Preto adentra o novo século aparelhada por uma massa de recursos físicos ambiente construído - apropriadas às finalidades da produção e do consumo que, aliadas ao processo de constituição da força de trabalho, produziriam as bases matérias para o impulso industrial. Ainda, reforça-se que

"o processo de produção do ambiente construído era o espelho da acumulação do capital engendrada na economia cafeeira; capital que só era investido nas cidades, porque eles se constituíam também como espaços privilegiados de reprodução desse capital (DEVESCOVI, 1985, p. 58)

Em Ribeirão Preto, a quantidade de café embarcado nas estações da estrada de ferro caiu 75\% entre 1905 e 1920. Em compensação a safra de 1919-20 mostrou uma maior produção de culturas diversificadas, como a cana de açúcar, o algodão, arroz, mandioca, fumo e milho - vale distinguir que boa parte dessa diversidade agrícola se deu graças aos pequenos produtores e proprietários que surgiram no período. Os grandes fazendeiros continuavam mirando em novos produtos substitutos, que sustentassem o modelo monocultor agroexportador. Inclusive, em 1902, o coronel Francisco Schmidt, maior produtor de café da região, plantou 60 alqueires de cana em terras antes reservadas para o café, em decorrência da geada severa desse ano, talvez antevendo a futura "vocação" agrícola da região (PIRES, 1996, p. 55). Isto é: ainda que a crise tenha possibilitado maior acesso ao território e à cidade, a lógica central da acumulação pela terra ainda permaneceu influente nas formas e traços de Ribeirão Preto.

\subsection{Ribeirão Preto no período populista (1930-1964)}

De acordo com dados do IBGE, Ribeirão Preto contabilizava 79.771 habitantes no anos 40, chegando a 92.160 na década de 1950 (aumento de 15,5\%). A taxa de urbanização de Ribeirão Preto destes mesmos censos foi de $71,8 \%$ e $81,7 \%$ em cada período, respectivamente. Durante esse período, constatou-se que a área cultivada de cana de açúcar 
em 1944 já era maior que a de café na região de Ribeirão Preto e, em 1950, superando a de algodão. Ao final de 1954, a produção canavieira já era maior que as duas outras culturas juntas (PIRES, 1996, p. 57). A expansão da cultura da cana, em conjunto com a instalação cada vez mais robusta de um parque fabril, contribuiu para o desenvolvimento da agroindústria açucareira na cidade, acompanhando a tendência de crescimento do setor no Estado de São Paulo.

A política desenvolvimentista de Juscelino Kubitschek teve grande impacto na reformulação do perfil econômico da região, na segunda metade da década de 50. O Plano de $\operatorname{Metas}^{35}$, que tinha grande foco no setor automobilístico e energético, contribuiu para que o parque industrial de Ribeirão Preto se diversificasse do perfil majoritariamente alimentício e de processamento agrícola. A partir desse período a cidade ganha indústrias químicas e metal-mecânicas, o que foi bastante conveniente para o consolidado setor agroexportador da cidade vez que possibilitou o aperfeiçoamento técnico do campo com a produção de máquinas agrícolas - o complexo agroindustrial. (FIGUEIRA, 2013). Tânica Figueira (2013, p. 110) destaca “ Tal fato introduziu uma relação entre a produção agrícola e a industrial, articulando a primeira às demandas da nova etapa (industrial) capitalista". Isto é, ainda que a cidade estivesse atualizando sua base econômica e produtiva, o poder ainda se manteve (e se fortaleceu) nas mãos de um grupo muito semelhante do que sempre governou a cidade.

O fim da segunda guerra foi fator importante para impulsionar a expansão da atividade canavieira vez que o açúcar figurou como item valioso no comercio internacional de gêneros alimentícios. Ainda, as usinas do litoral nordestino não conseguiram acompanhar o aumento na demanda interna e externa, abrindo oportunidades para as grandes propriedades do Sudeste avançassem no mercado. No período 1940-1950, em virtude de pressões dos usineiros paulistas, o Instituto do Açúcar e Alcool (IAA), em conjunto com a "Comissão de Estudos sobre o Álcool-Motor" alterou o mapa da

35 "Esse ideal desenvolvimentista foi consolidado num conjunto de 30 objetivos a serem alcançados em diversos setores da economia, que se tornou conhecido como Programa ou Plano de Metas. (...) Guardadas as devidas proporções, como governador de Minas Gerais de 1951 a 1955, JK já tinha eleito o binômio energia e transportes como metas de desenvolvimento para a sua gestão. (...) As metas deveriam ser definidas e implementadas em estreita harmonia entre si, para que os investimentos em determinados setores pudessem refletir-se positivamente na dinâmica de outros. O crescimento ocorreria em cadeia. A meta de mecanização da agricultura, por exemplo, indicava a necessidade de fabricação de tratores, prevista na meta da indústria automobilística." SILVA, Suely Braga.O Brasil de JK - 50 Anos em 5: O Plano de Metas. FGV Online Centro de Pesquisa e Documentação de História Contemporânea do Brasil (CPDOC). Disponível em http://cpdoc.fgv.br/producao/dossies/JK/artigos/Economia/PlanodeMetas. Acessado em 29 de Junho de 2017. 
distribuição espacial de zonas favoráveis à produção de cana, incentivando a instalação de novas usinas em São Paulo, sendo a maior parte na Região de Ribeirão Preto. (PIRES, 1996, p. 58)

O embargo comercial norte-americano à Cuba, nos anos 1960, deu novo impulso à atividade no Brasil. Os investimentos públicos e privados na infraestrutura produtiva do setor sofreram com o excesso de expectativa da década anterior, o que começou a corroer as conquistas realizadas. Entretanto, a questão política no golfo do México favoreceu as exportações brasileiras e consolidou o país (e a região) como produtores dessas commodities. Se no período da crise do café (1929) as pressões sobre a terra permitiram maior acesso e diversificação do uso da terra, agora, novamente, as forças políticas e econômicas pressionaram para a concentração fundiária e o perfil monocultor na Região, com grandes consequências para a organização da cidade. (PIRES, 1996, p.60)

$\mathrm{O}$ aquecimento econômico da cidade e a promessa de oportunidades justificam o salto populacional apresentados pelos dados do IBGE. Em função disso o uso residencial extrapolou as delimitações da região Central. Diversos loteamentos foram implantados em vários setores da cidade, mantendo-se o padrão de ocupação horizontal e de baixas densidades em todas as regiões. De acordo com levantamento da Secretaria de Planejamento Urbano e Gestão Pública Municipal, enquanto na década de 1930 apenas dois loteamentos foram aprovados pelo poder legislativo - em 1937, a Quinta da Alvorada e, em 1938, a Vila Gertrudes -, entre 1940 e 1959 constituíram-se 74 loteamentos no município de Ribeirão Preto, sendo 28 na zona Norte, 20 na zona Oeste, 13 na zona Sul e 13 na zona Leste.

Figura 2 - Histórico do registro de parcelamento do solo (1910 - 1939) 


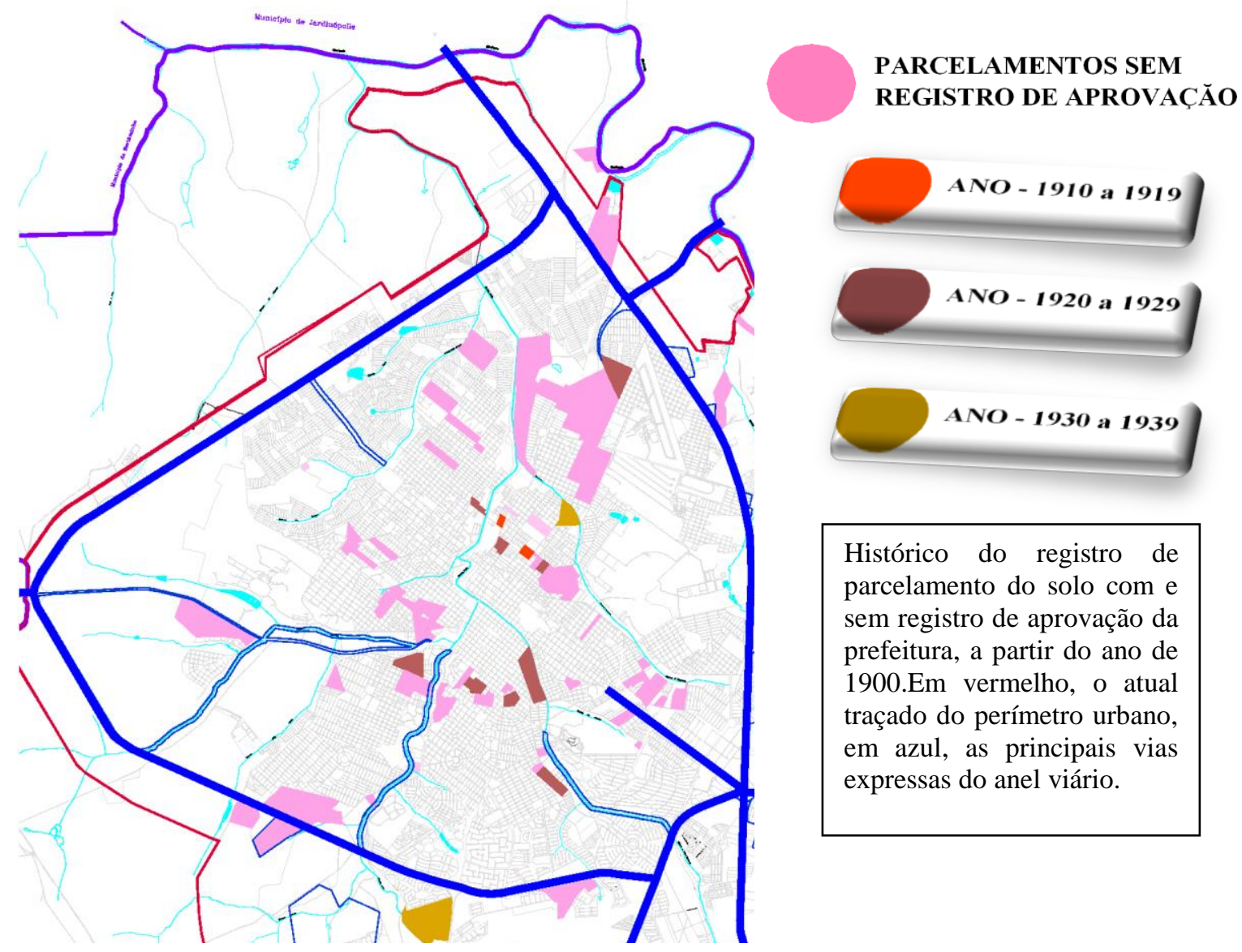

Fonte: SERPLAN - Secretaria de Planejamento e Gestão Pública de Ribeirão Preto, 2017.

Figura 3 - Histórico do registro de parcelamento do solo (1910 - 1969 


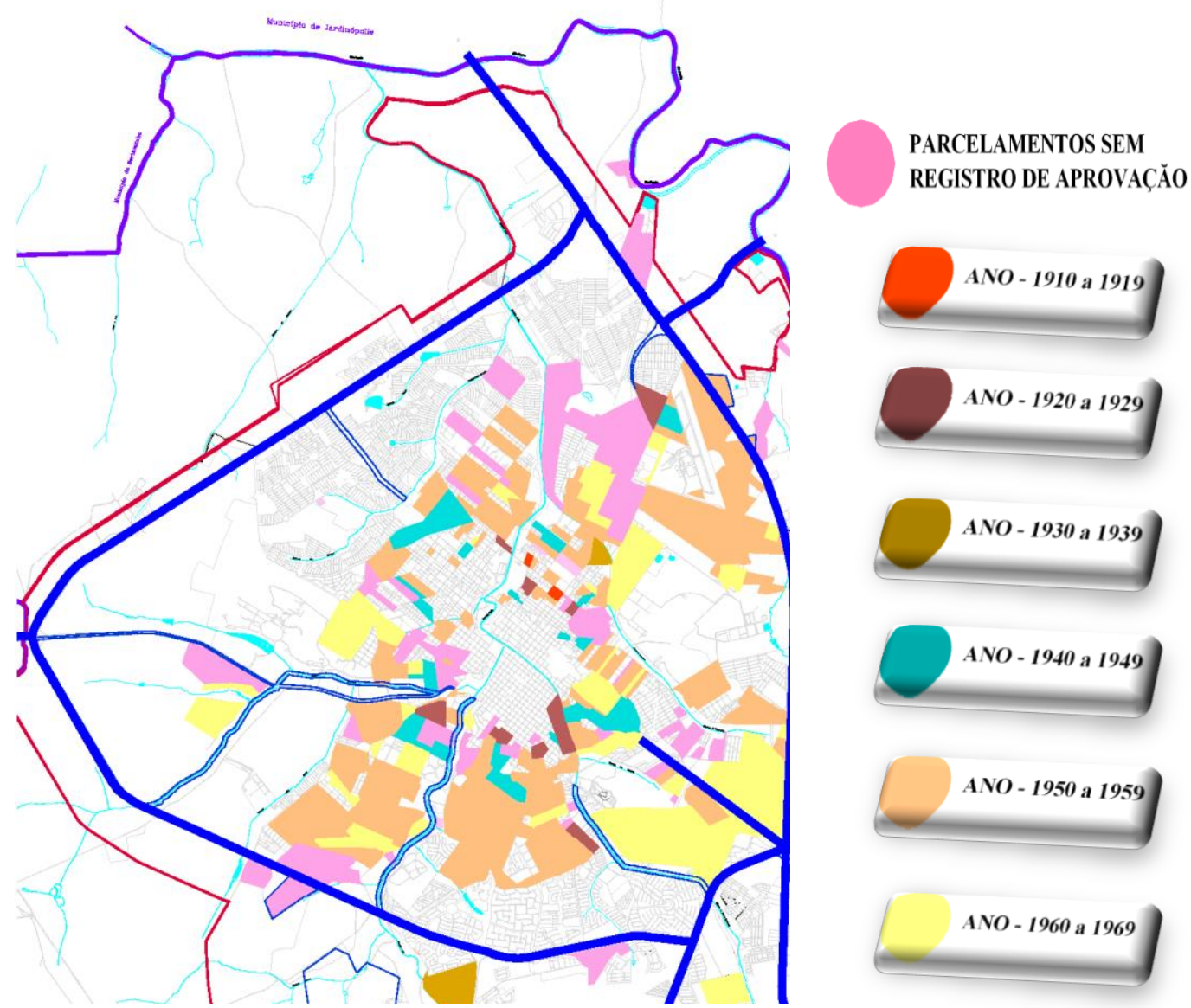

Fonte: SERPLAN - Secretaria de Planejamento e Gestão Pública de Ribeirão Preto, 2017.

Muito embora todas as regiões da cidade tenham demonstrado expansão significativa (a partir da aprovação - ou não - de parcelamentos), é possível perceber uma maior ocupação da região sul ao longo dos anos. Segundo Tânia Figueira (2013, p. 112), durante esse espraiamento a cidade manteve a distinção territorial social, conforme a configuração já estabelecida pelo quadrilátero central desde o século XIX: "enquanto nos quadrantes Norte e Oeste do município eles foram destinados aos estratos populacionais de menor renda, a zona Leste acabou sendo ocupada pela população de renda mensal média e, na zona Sul, instalaram-se os segmentos populacionais de renda elevada" (FIGUEIRA, 2013, p. 112). O que talvez explique a maior preferência dos investimentos imobiliários nas regiões ao sul do quadrante central.

Observa-se no mapa, também, uma quantidade extensa de terra parcelada sem registro de aprovação do poder público. Não caberia explorar as razões por trás de cada parcelamento irregular nessa pesquisa, entretanto, mesmo sem essa informação é possível perceber a precariedade e a dualidade do planejamento da expansão urbana na cidade. Precariedade porque, se desde essa época, a prefeitura não revelou e solucionou as falhas de documentação de áreas tão extensas, é difícil planejar o espaço sob insegurança jurídica. 
É difícil mensurar, por exemplo, as justificativas técnicas para eventual aumento do perímetro urbano sem saber a real situação jurídica dos lotes e vazios urbanos presentes dentro dessa zona (assim como dificulta a aplicação de sanções urbanísticas sem saber a condição jurídica das terras).

A dualidade, por sua vez, se verifica na diferença de tratamento entre os vários "tipos sociais" de ocupantes irregulares ao longo do processo de urbanização. Se de um lado empreiteiras ou grandes donos de terra são blindados contra a lei, recebendo indulgências da prefeitura ou do poder judiciário, de outro as pessoas em situação de pobreza são constante e assertivamente removidas de suas ocupações sob justificativa de cumprir a lei. (SANTOS, 2015). São essas “camadas de legalidade” explicadas por James Holston (2013) que contribuem para a manutenção da estratificação social e racial da cidade como ordem absoluta, comprometendo a viabilidade planejamento urbano, como se mostrará adiante.

Justamente por conta do crescimento urbano sem muitos critérios técnicos e cheio de problemas, em 1944 foi encomendado ao urbanista José de Oliveira Reis o que pode ser considerado o primeiro Plano Diretor de Ribeirão Preto: "um conjunto de normas para o controle e o adensamento do crescimento da cidade" (FIGUEIRA, 2013, p. 115). Entretanto, questões políticas internas da gestão municipal impediram que ele fosse adotado e implementado completamente. Ainda assim, o projeto trouxe à tona diversos pontos problemáticos e diagnósticos sobre a condição urbana de Ribeirão Preto, o que contribuiu para revelar a importância tanto das instituições administrativas quanto da legislação no que tange ao planejamento urbano. Em 1960 parte dessa lei seria utilizada para o estabelecimento do Plano de Vias, aprovado pelos poderes Legislativo e Executivo com o intuito de organizar a estrutura viária da cidade a exemplo dos regramentos semelhantes de São Paulo e Rio de Janeiro:

Figura 4 - Proposta Viária e de Zoneamento Urbano do Plano Diretor de José de Oliveira Reis, em 1945 


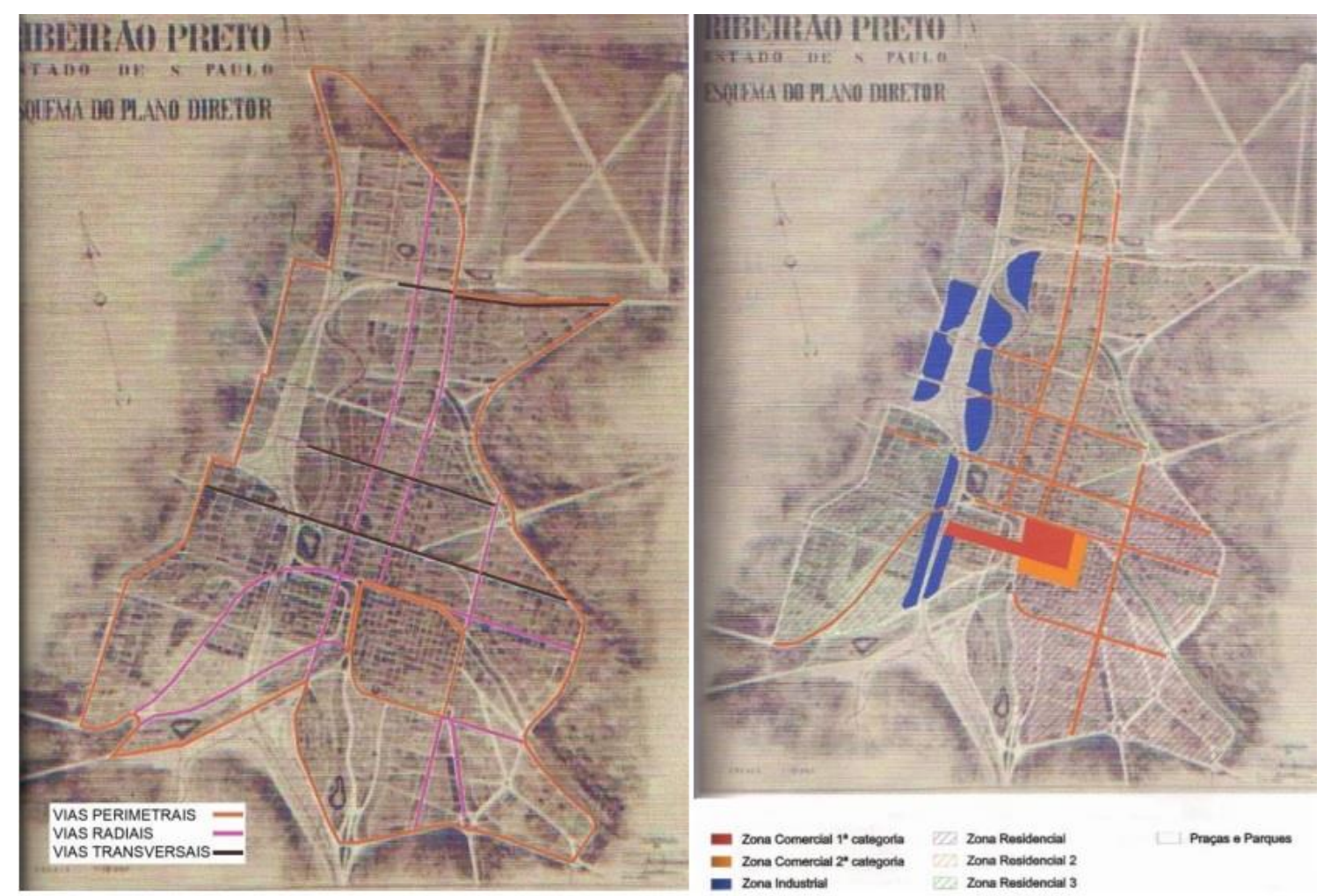

FONTE: Arquivo Público e Histórico do Município de Ribeirão Preto. 1945; FIGUEIRA, 2013, p. 116

Segundo Tânia Figueira (2013, p. 115) "o plano propôs um sistema viário que integrasse a região Central, seu entorno e os loteamentos encontrados nas áreas de expansão urbana, ressaltando a importância de manterem-se os limites do perímetro urbano em uma área compacta, a fim de evitar a proliferação de vazios urbanos [já existentes]”. Isto é, já se tinha noção de que a ampliação irrestrita das linhas perimetrais da cidade poderia incentivar a especulação mobiliária, vez que muitos investidores comprariam os lotes a preços baixos e os deixariam inutilizados até momento oportuno que os valorizasse, conforme a cidade se aproximasse. O poder público Ribeirão pretano já tinha conhecimento de que a alteração de perímetro urbano gerava interferências tanto econômicas como demográficas pelo território da cidade (desde 1945), o que torno ainda mais intrigante as novas proposições de leis contrárias a esses pressupostos.

No que diz respeito ao Plano de Vias de 1960, propôs-se uma malha essencialmente rodoviarista baseada na estrutura urbana já consolidada, hieraquizando as diferentes vias perimetrais, radiais, transversais. Isto é, o planejamento não pretendia interferir nas problemáticas segmentações sócio-espaciais da cidade, limitando-se à otimização e fluidez do trânsito. As obras convergiam interesses municipais e estaduais vez que a região administrativa de Ribeirão Preto se consolidava como polo urbano interiorano desde o começo do século XX. Seria uma ótima oportunidade tanto para o governo 
implantar o "novo modelo" de fazer urbano, totalmente vinculado à utilização do carro (a gosto das grandes montadoras recém instaladas no país) quanto para a administração local, que seria beneficiada com repasses de verba pública em obras de grande porte (FIGUEIRA, 2013, p.117).Participaram dessas determinações tanto Comissões técnicas do Departamento de Obras Públicas do Município (DOP) como o Departamento de Estradas e Rodagem do Estado de São Paulo (DER), que financiou a obra.

Figura 5 - Plano de vias de Ribeirão Preto - 1960

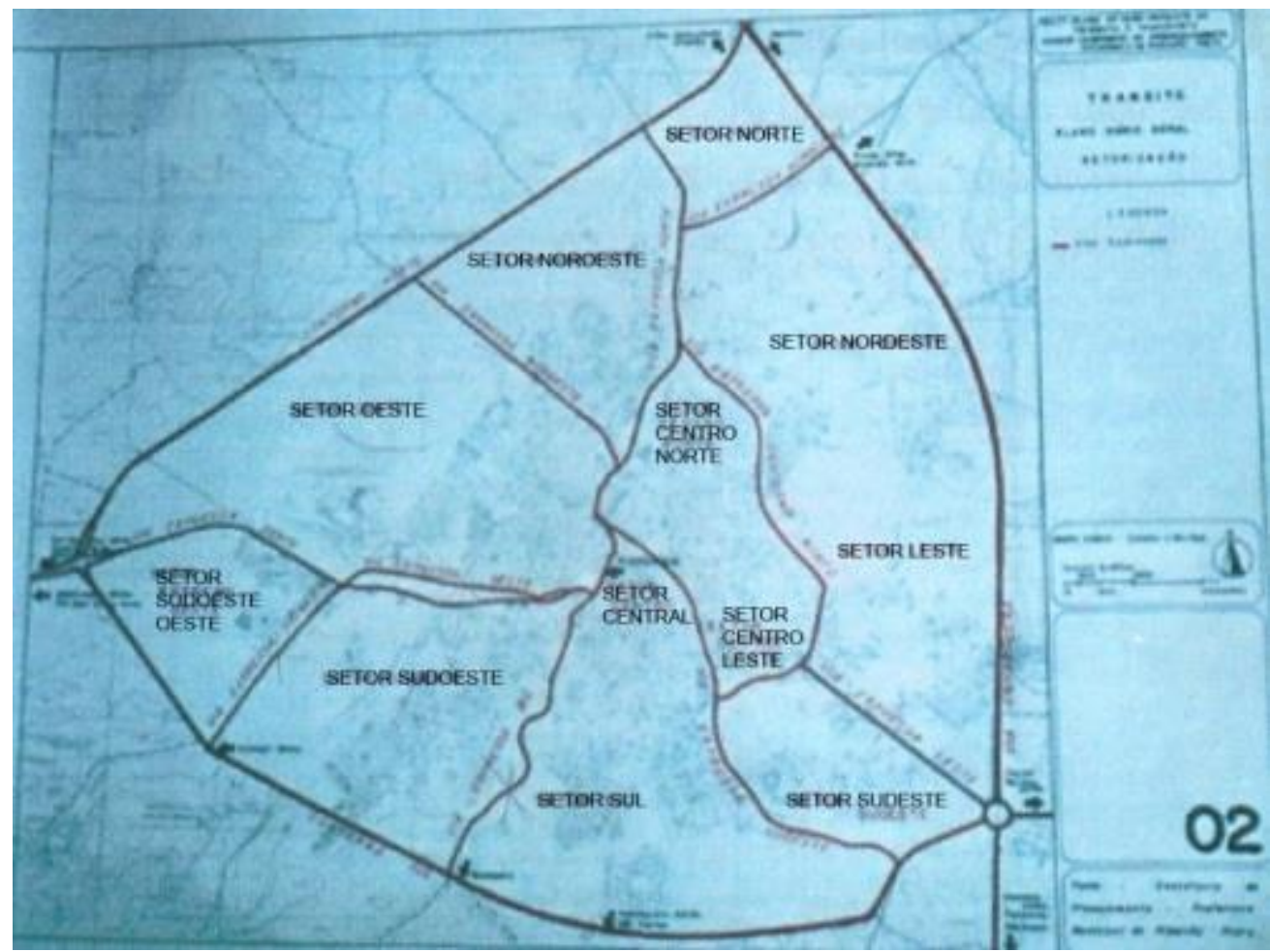

Fonte: Arquivo Público e Histórico de Ribeirão Preto, 1960. Por FIGUEIRA, 2013. p.117

De acordo com Tania Figueira, (2013, p. 118) a implantação desse sistema reforçou a importância do centro em relação às outras regiões da cidade, sendo um ponto de confluência das funções mais vitais da vida urbana de Ribeirão Preto. A região, que já era 
valorizada, passa a valer ainda mais graças aos investimentos públicos em infraestrutura. Mais uma vez vale ressaltar que o estrato mais rico da cidade ocupava justamente os setores centrais, como o bairro Higienópolis, desde o século XIX, o que permite enxergar uma manutenção das relações patrimoniais de poder (decisões políticas e gasto do dinheiro público para garantir ganhos da elite local com especulação imobiliária). O plano viário rodoviarista, portanto, além de incentivar o consumo de automóveis, possibilitou a criação de "avenidas imobiliárias" altamente lucrativas para a indústria da construção civil. Isso obviamente deu força para esses setores da economia, como era planejado pela política desenvolvimentista de Juscelino Kubitschek e, ainda, o alargamento do perímetro urbano juntamente com a implantação de uma série de loteamentos em torno das novas vias influenciou o espraiamento da cidade entre as décadas de 1960 e 1980, particularmente nas regiões do entorno das vias radiais e próximas à perimetral externa, ou Anel Viário (FIGUEIRA, 2013, p. 118)

Nesse sentido, é interessante notar como a lei ordinária 1510 de 1964 (RIBEIRÃO PRETO, 1964), que altera o perímetro urbano daquele ano, orienta a determinação dessa zona justamente tomando o plano viário como parâmetro.

\section{DELIMITA O PERÍMETRO URBANO DO DISTRITO DA SÉDE DE RIBEIRÃO PRÊTO.}

Faço saber que a Câmara Municipal decretou e eu promulgo a seguinte lei:

ARTIGO $1^{\circ}$ - O perímetro urbano do distrito da séde do Município de Ribeirão Prêto, fica delimitado pela área prevista na Lei $\mathrm{n}^{\circ} 1087$, de 16 outubro de 1961 e mais tôda a Avenida Barão do Bananal e os loteamentos existentes no seu prolongamento, atravessando a via Anhanguera e seguindo pela rua Dr. Adhemar de Barros, até a rua Prof. Joaquim de Faria, seguindo por esta até a rua Álvaro Abranches Lopes, e, seguindo por esta até a via Anhanguera em contôrno à praça pública Presidente Vargas. (grifo nosso)

\section{Palácio Rio Branco, Dr. Welson Gasparini} Prefeitura Municipal

Pelo que se extrai, a lei de 1964 vem simplesmente incluir novos setores loteados dentro do perímetro urbano, sem grandes justificativas técnicas para tanto. Segue-se uma lógica muito peculiar de expansão urbana em que 1) as vias (rodoviaristas) são construídas com dinheiro público e induzem o crescimento para as regiões limítrofes da cidade, adentrando a zona rural desvalorizada. 2) conforme o espaço é "colonizado" pelo capital privado, a administração pública regulariza retroativamente a ocupação através da alteração do perímetro urbano, e assim o instrumento supostamente ganha função de indulgência urbanística (para quem pode compra-la). 


\begin{tabular}{|c|c|c|c|}
\hline $\mathrm{N}^{\mathrm{o}}$ & $\begin{array}{c}\text { Tipo } \\
\text { normativo }\end{array}$ & $\begin{array}{c}\text { Data de } \\
\text { publicação }\end{array}$ & Conteúdo normativo \\
\hline 031 & Ato & $02 / 03 / 1935$ & Delimita a zona urbana da cidade de ribeirão preto. \\
\hline 033 & Ato & 05/02/1936 & Delimita a zona urbana da cidade de ribeirão preto. \\
\hline 028 & Ato & $30 / 11 / 1938$ & $\begin{array}{l}\text { Delimita o perimetro urbano do distrito de paz de vila } \\
\text { bomfim. }\end{array}$ \\
\hline 032 & Ato & $26 / 12 / 1938$ & $\begin{array}{l}\text { Delimita o perimetro urbano do distrito de paz de } \\
\text { guatapará. }\end{array}$ \\
\hline 075 & Ato & 05/09/1939 & $\begin{array}{l}\text { Delimita o perimetro urbano da séde do distrito de } \\
\text { paz de ribeirão preto e vila bomfim. }\end{array}$ \\
\hline 168 & $\begin{array}{c}\text { Lei } \\
\text { Ordinária }\end{array}$ & $23 / 11 / 1950$ & Divide a cidade em sete zonas. \\
\hline 272 & $\begin{array}{c}\text { Lei } \\
\text { Ordinária }\end{array}$ & 24/11/1952 & $\begin{array}{l}\text { Dispõe sôbre limpeza e conservação dos cursos de } \\
\text { água existentes no perímetro urbâno e suburbano da } \\
\text { cidade e distritos. }\end{array}$ \\
\hline 720 & $\begin{array}{c}\text { Lei } \\
\text { Ordinária }\end{array}$ & $27 / 06 / 1958$ & $\begin{array}{l}\text { Modifica dispositivos do código de posturas - } \\
\text { (terrenos baldios no perimetro urbano). }\end{array}$ \\
\hline 843 & $\begin{array}{c}\text { Lei } \\
\text { Ordinária }\end{array}$ & 25/10/1959 & $\begin{array}{l}\text { Regulariza as construções feitas sem a devida } \\
\text { aprovação da prefeitura, no perímetro urbano. }\end{array}$ \\
\hline 927 & $\begin{array}{c}\text { Lei } \\
\text { Ordinária }\end{array}$ & $01 / 06 / 1960$ & $\begin{array}{l}\text { Dispõe sôbre terrenos baldios no perímetro urbano da } \\
\text { cidade }\end{array}$ \\
\hline 1087 & $\begin{array}{c}\text { Lei } \\
\text { Ordinária }\end{array}$ & $16 / 10 / 1961$ & $\begin{array}{l}\text { Delimita o perímetro urbano do distrito da sede de } \\
\text { ribeirão preto. }\end{array}$ \\
\hline 1110 & $\begin{array}{c}\text { Lei } \\
\text { Ordinária }\end{array}$ & 20/11/1961 & $\begin{array}{l}\text { Modifica a primeira zona do perímetro urbano } \\
\text { estabelecido pela lei. } 168 \text { de } 1950\end{array}$ \\
\hline 1510 & $\begin{array}{c}\text { Lei } \\
\text { Ordinária }\end{array}$ & $04 / 12 / 1964$ & $\begin{array}{l}\text { Delimita o perímetro urbano do distrito da séde de } \\
\text { ribeirão prêto. }\end{array}$ \\
\hline
\end{tabular}

\subsubsection{O perímetro urbano na legislação municipal entre (1930-1964)}


Tebela 4 - Tipos normativos que mencionam a palavra "perímetro urbano" em Ribeirão Preto, no período entre 1930 e 1964. Fonte: Elaboração do autor

Utilizando ferramenta de busca legislativa municipal. disponível no site oficial da prefeitura de Ribeirão Preto, delimitou-se o objeto de pesquisa com a palavra chave "perímetro urbano" bem como foi delimitado o período de abrangência entre 1930 até 1964. O intuito é analisar se houve alterações na lei de perímetro, qual o contexto de menção ao instrumento e relacionar essas informações com o contexto político, econômico e histórico recortado. As células em destaque, coloridas, mostram as vezes em que a linha divisória foi alterada pela gestão municipal.

De todas as leis que alteraram o perímetro no período, além de não apresentarem critérios técnicos e específicos de ampliação elencados no corpo da norma, foi recorrente ${ }^{36}$ o embasamento na Lei Estadual 2.484 de 1935, que regula o procedimento necessários para que as zonas rurais e urbanas fossem estabelecidas:

\section{LEI Estadual N. 2.484, DE 16 DE DEZEMBRO DE 1935}

Art. 8. ${ }^{\circ}$ - Os primeiros prefeitos eleitos providenciarão, desde logo os estudos necessarios á delimitação da zona urbana, com referencia á séde do município e as de cada districto de paz, tornando clara e tacilmente reconhecivel, no terreno, toda a linha perimetrica, de mode a poderem as Camaras fazer, em lei. a devida fixação.

$\$ 1$ 1. $^{-}$- Não poderá a linha perimetrica da zona urbana afastar-se mais de cem metros além dos pontos extremos da povoação respectiva, caracterizados pela existencia de qualquer dos melhoramentos seguintes: illuminação publica, bondes, exgottos, abastecimento de agua, calçamento e guias para passeio. $\$ 2 .^{\circ}$ - A lei, que fixar a linha perimetrica, será de pois de publicada, remettida pelo prefeito á repartição arrecadadora do Estado, no municipio, o ao Departamento de Cadastro Immobiliario.

Art. 109 - Os municipios fixarão os limites do perimetro urbano das povoações, que ainda poderá ser subdividido para juizo fiscal e de policia. Emquanto não forem fixado esses limites, será considerada urbana toda a zona adjacente ás povoações, servidas por algum destes melhoramentos: illuminaçao publica, bondes, exgottos, abastecimento de agua, calçamento e guias para passeio

Observa-se que a lei estadual centraliza a atividade de determinação do perímetro urbano nas mãos do executivo municipal. É o prefeito quem tem legitimidade de convocar equipe técnica e estabelecer os critérios de definição do que é urbano e o que é rural, ainda que a fixação em lei dependa de aprovação da câmara municipal. A introdução do ato 075

\footnotetext{
${ }^{36}$ A partir da lei 168 de 1950 a redação das leis de alteração do perímetro passa a conter a frase "Faço saber que a Câmara Municipal decretou e eu promulgo a seguinte Lei: (...). O que denota uma mudança no procedimento, agora mais centralizado no poder legislativo que no executivo.
} 
de 1939 (RIBEIRÃO PRETO, 1939) ilustra esse centralismo na figura do prefeito, que justifica a determinação do perímetro

"Considerando, que foram demarcados os perimetros urbanos dos Distrito de
Vila Bomfim e Guatapará;(...) Considerando, que os trabalhos pela Comissão,
por mim nomeada para éssa delimitação, foram aprovados em reunião, em que
esteve presente o Coletor Estadoal, confórme, Áta de 13 de Junho de 1939,
e, Considerando, que é opôrtuno ratificar os nómes das Ruas, Avenidas e Praças
dos Distrito de Ribeirão Preto e do de Vila Bomfim”

Sabe-se que, durante esse período, a classe política da cidade ainda era extremamente dominada por representantes da oligarquia agrária (PIRES, 1996), e, portanto, é bastante provável que esses prefeitos guiassem suas decisões de acordo com os interesses dela. Ainda, a lei é bastante categórica no que diz respeito ao critério objetivo de expansão, não podendo a lei perimétrica expandir-se mais de cem metros dos pontos extremos da ocupação servidos de melhoramentos e infraestrutura. A princípio a redação parece favorável ao planejamento "responsável" pois esse limite ao poder decisório do prefeito evitaria que o perímetro fosse aumentado arbitrariamente, causando o espraiamento nocivo da cidade e alimentando a especulação imobiliária. Ainda, condicionaria o aumento do perímetro urbano ao melhoramento da infraestrutura urbana, evitando ocupações "sem cidade". Entretanto, não fica claro qual a intenção do legislador vez que o art.109 permite que qualquer núcleo servido de calçamento ou água seja considerado automaticamente zona urbana, arruinando quaisquer pretensões de condicionamento de alteração do perímetro aos critérios estabelecidos no artigo anterior. $\mathrm{E}$ também, a lei não enseja qualquer tipo de sanção pelo descumprimento de seu conteúdo, tornando-a vulnerável à ineficácia na prática. Nesse sentido James Holston (2013) enfatiza o quanto a indefinição e a confusão das leis territoriais no Brasil são estratégica e propositalmente estabelecidas para privilegiar a classe política (rica e instruída), vez que seriam os únicos hábeis a "andar pelo labirinto" e manejar uma solução judicial ou extrajudicial a seu favor.

Além das leis municipais específicas de alteração do perímetro o ato 018 de 1938 (RIBEIRÃO PRETO, 1938) se destaca por determinar diferentes taxas de limpeza pública e impostos sobre a conservação do calçamento dependendo do bairro a que se refere. A região central, mais rica, tem custos muito maiores do que as regiões no limite do perímetro urbano. Segue o disposto no dispositivo:

Imposto sobre conservação $\quad$ do calçamento.

\begin{tabular}{|l|r|}
\hline $1-$ No perímetro central por metro linear de frente & $2 \# 000$ \\
\hline
\end{tabular}

\begin{tabular}{|l|r}
\hline 2 - Nas demais ruas da cidade, idem idem & $1 \# 500$ \\
\hline
\end{tabular} 
Art. $4^{\circ}$ - A Taxa de Limpesa Publica, regulada pela mesma Lei no 39 , fica igualmente reduzida, e será cobrada de acôrdo com a tabela seguinte:

Taxa

de

Limpesa

Publica

1 - Nas ruas do perimetro central, por metro linear de frente $1 \# 000$

2 - Na zona da primeira divisão urbana, idem $\# 600$

3 - Na zona da 2 divisão urbana, idem $\# 300$

4 - Na zona da $3^{\text {a }}$ divisão, havendo melhoramentos, luz e sargetas, idem \#200

É possível especular que as maiores cobranças nas zonas ricas buscassem desonerar as populações mais vulneráveis e menos servidas de infraestrutura, bem como arrecadar o máximo de recursos cobrando mais do topo da pirâmide social. Entretanto, ainda que as intenções fossem as melhores possíveis é inegável o quanto essas determinações aumentavam o custo de vida nas regiões centrais e barravam o acesso de camadas mais pobres àquele espaço, garantindo exclusividade para os moradores mais abastados.Ainda que não se relacione diretamente com o perímetro urbano, esse ato contribui para o formato excludente e segregado de expansão urbana na cidade vez que força a população de baixa renda a ocupar espaços cada vez mais afastados do centro, bloqueado pelo muro social.

\subsection{Ribeirão Preto no Regime Militar (1964-1985) - A Cidade da Cana}

O patamar econômico atingido pelo município de Ribeirão Preto nas décadas de 1940-50 teve seu ritmo de expansão continuado no período, sobretudo nos setores secundário (indústria) e terciário (serviços) da economia regional, muito embora ainda dependessem da agricultura como base econômica de desenvolvimento. Destaca-se o cultivo e o processamento da cana-de-açúcar que forneceu subsídios monetários para a indústria metal mecânica (máquinas pesadas), além dos setores de implementos agrícolas e bens de capital. (PIRES, 1996, p. 86-88; FIGUEIRA, 2013, p. 119). A partir da década de 1970, o choque internacional do petróleo e as crises ligadas à produção e distribuição de hidrocarbonetos influenciou a implementação, em nível nacional, das políticas econômicas do Proálcool ${ }^{37}$.O programa foi responsável por um considerável ciclo de desenvolvimento

\footnotetext{
${ }^{37}$ O Pró-Álcool ou Programa Nacional do Álcool foi um programa de substituição em larga escala dos combustíveis veiculares derivados de petróleo por álcool combustível, financiado pelo governo do Brasil a partir de 1975 devido a crise do petróleo em 1973 e mais agravante depois da crise de 1979. O programa teve fim em 1990.
} 
econômico na região, sustentado até a o final da primeira metade da década de 80 (quando a maior parte do Brasil enfrentava grave crise). Em função disso, segundo dados do IBGE de 1970-80, a população economicamente ativa passou a aumentar consideravelmente no setor terciário, dada a necessidade de diversificação no comércio, nos serviços e na área financeira que a agroindústria exigiu. Nesse período Ribeirão Preto se alça como terceira maior praça financeira do país, atraindo olhares do mercado de capitais (FIGUEIRA, 2013, p. 118-119)

O mercado imobiliário acompanhou esse dinamismo, como se constata a partir do registro de 51 novos lotealmentos aprovados pela Câmara Municipal entre a década de 60 e 80:

\footnotetext{
Os bairros Ribeirânea, Jardim Canadá e City Ribeirão, por exemplo, foram conformados neste período com aprovações datadas, respectivamente, em 1967, 1970 e 1977. Eles se caracterizam, por estarem localizados nas proximidades do Anel Viário [ou atual perímetro urbano], nas áreas lindeiras aos Ribeirão Shopping [de 1981] e Novo Shopping [de 1999], com uso e ocupação destinados, basicamente, aos extratos de renda elevada da cidade - conforme observado pelas FIGURAS 6 e 61. Segundo dados da Secretaria de Planejamento e Gestão Pública [1995], tais aprovações aumentaram substantivamente a área urbana da cidade, com um crescimento de $7,32 \mathrm{Km}^{2}$ na zona Sul. (FIGUEIRA, 2013, p. 120)
}

Figura 6 - Parcelamentos Aprovados pela Prefeitura de Ribeirão Preto (1910 - 1989) 


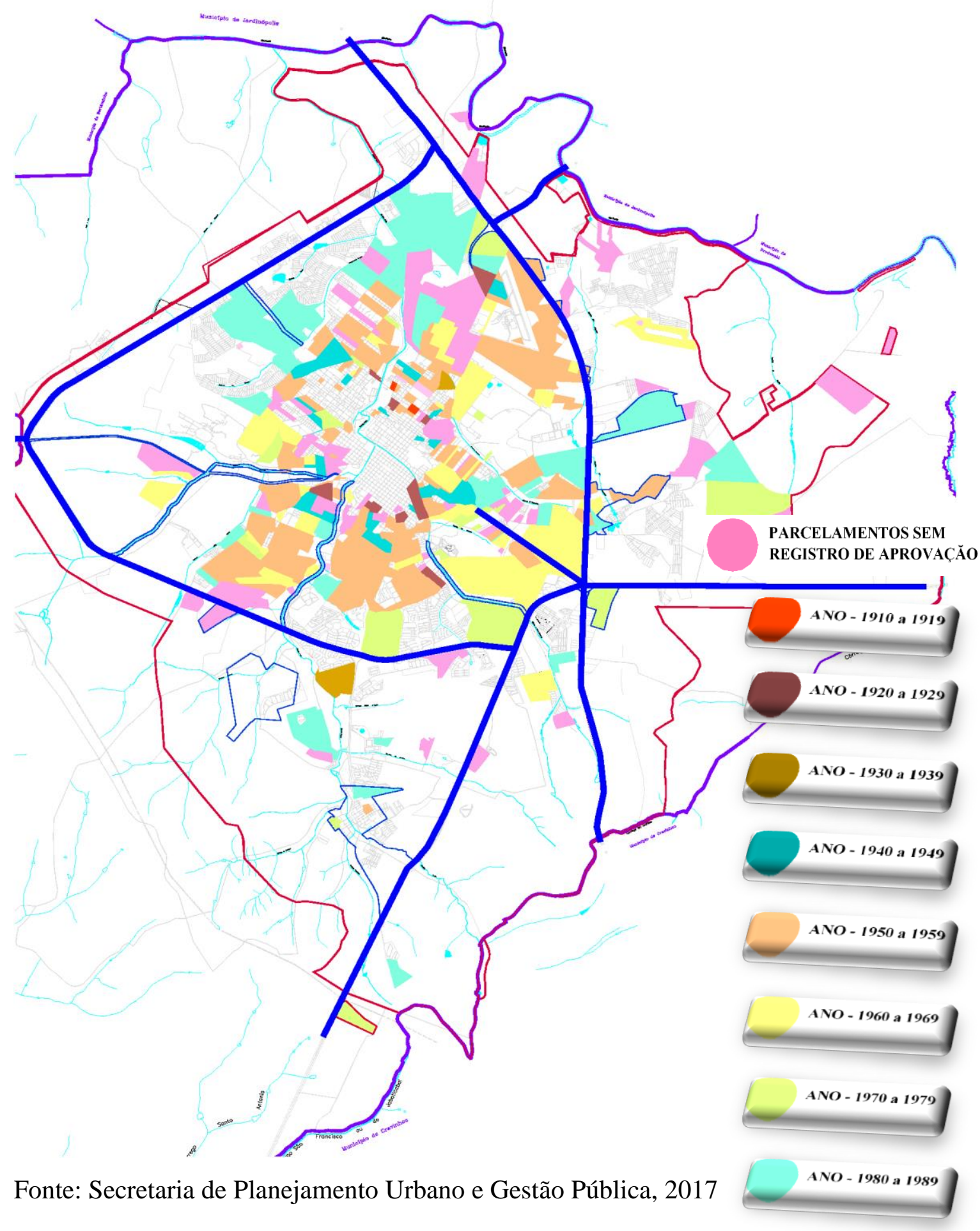

É interessante notar que entre as décadas de 60 e 70 houve uma reformatação do tamanho médio das propriedades de terra na zona rural da cidade. As que possuíam entre 100 e 1000 hectares (ha.) representavam 17,7\% do total de propriedades em 1960, ocupando cerca de 43,6\% da área canavieira, enquanto em 1970 esses números mudam para $15,2 \%$ e 47,5\% respectivamente. O que demonstra um considerável aumento da área 
média no período. Ao longo da década de 70 essa tendência de concentração continua e se acentua, com queda da participação da área ocupada por imóveis de menos de 100 ha e aumento do número de imóveis com mais de 1000 ha (esses que representavam $0,8 \%$ do número total de propriedades e passam a deter 38,3\% das terras). A partir de 1975, com a implantação do programa Proálcool, foi registrado ainda maior tendência à concentração fundiária (PIRES, 1996, p. 81-82):

(...) estabelecimentos com menos de 200 ha (91, 9\% das propriedades) detinham $30 \%$ da área; em 1980, esses estabelecimentos representavam $90,8 \%$ do total e detinham $26,7 \%$ da área. Em contrapartida, no mesmo período, os estabelecimentos com mais de 1000 ha diminuíram em número de estabelecimentos (de $0,8 \%$ para $0,7 \%$ ) e aumentaram em área (de $38,3 \%$ para $40 \%$ ). No estrato imediatamente inferior a esse, compreendendo as propriedades entre 500 e 1000 ha, também verificou-se aumento de área (FIBGE apud PIRES, 1996, p. 82)

De acordo com Graziano da Silva os cenários econômico e fundiário do município descrevem e emergência de um novo e mais complexo padrão agrícola, a partir desse momento. Segundo o autor, o momento inicia "integração de capitais sob o comando do capital financeiro, com reflexos não apenas na base técnica de atividade agrícola, mas principalmente no plano da concentração e centralização do capital e da terra e no plano das relações com o Estado" (GRAZIANO DA SILVA, 1996, p.33)

Nesses sentido, é curioso analisar as estatísticas à luz das percepções do economista Thomas Piketty (2014). O aumento nos índices de concentração fundiária em Ribeirão Preto de 1970-80 coincide com o início da tendência de concentração da renda no mundo industrializado, quando o rentismo do capital passa ser mais vantajoso que o capital produzido pelo trabalho. Harvey (2005) analisa que no mesmo período em que os choques do petróleo desencadeiam sucessivas quedas no crescimento e no rendimento mundo afora, surge a política neoliberal com seu distorcido uso do sistema de crédito, tornando ainda mais agressivo o processo de acumulação do capital. De acordo com o autor, essa política funcionou como redistribuidora da riqueza e da renda para as altas esferas da classe capitalista, obra dos mecanismos que comporiam a chama "acumulação por espoliação". Com base na teoria de Marx, esse processo seria a continuidade da acumulação primitiva de capital e seria a responsável pelo padrão da apropriação da riqueza na atual fase de organização do modo de produção capitalista, tendo como características a privatização da terra, a conversão de formas estatais e coletivas em propriedade privada, a supressão de direitos aos bens comuns, os processos neocoloniais de apropriação privada de ativos (como recursos naturais) e, o mais devastador de todos, o uso do sistema de crédito como 
meio radical de apropriação privada do excedente econômico. (2005, p. 171 apud ROYER, 2013, p. 26)

\subsubsection{O perímetro urbano na legislação municipal entre (1964-1985)}

Tabela 5 - Tipos normativos municipais que mencionam a palavra "perímetro urbano" em Ribeirão Preto, no período entre 1964 e 1988.

\begin{tabular}{|c|c|c|c|}
\hline $\mathrm{N}^{\mathrm{o}}$ & $\begin{array}{c}\text { Tipo } \\
\text { Normativo }\end{array}$ & $\begin{array}{c}\text { Data de } \\
\text { publicação }\end{array}$ & Conteúdo \\
\hline 1840 & $\begin{array}{c}\text { Lei } \\
\text { Ordinária }\end{array}$ & 11/10/1966 & $\begin{array}{l}\text { Dá nova delimitação aos perímetros urbanos dos } \\
\text { distritos da séde e de bonfim paulista. }\end{array}$ \\
\hline 1928 & $\begin{array}{c}\text { Lei } \\
\text { Ordinária }\end{array}$ & 08/06/1967 & $\begin{array}{l}\text { Delimita o perímetro urbano do distrito de } \\
\text { guatapará. }\end{array}$ \\
\hline 2297 & $\begin{array}{c}\text { Lei } \\
\text { Ordinária }\end{array}$ & 07/11/1969 & $\begin{array}{l}\text { Dá nova delimitação aos perímetros, da séde do } \\
\text { município e dos distritos de bonfim paulista e } \\
\text { guatapará. }\end{array}$ \\
\hline 2916 & $\begin{array}{l}\text { Lei } \\
\text { Ordinária }\end{array}$ & $26 / 08 / 1974$ & $\begin{array}{l}\text { Regulariza as construções feitas, no perímetro } \\
\text { urbano, sem o licenciamento da prefeitura, } \\
\text { obedecidas as formalidades que especifica. }\end{array}$ \\
\hline 3236 & $\begin{array}{c}\text { Lei } \\
\text { Ordinária }\end{array}$ & 18/11/1976 & $\begin{array}{l}\text { Dispõe sobre plano diretor de desenvolvimento } \\
\text { integrado - organização territorial - loteamentos, } \\
\text { reloteamentos, arruamentos, abertura e } \\
\text { prolongamento de vias, retalhamento de imóveis } \\
\text { em geral e dá outras providências. }\end{array}$ \\
\hline 3346 & $\begin{array}{l}\text { Lei } \\
\text { Ordinária }\end{array}$ & 28/09/1977 & $\begin{array}{l}\text { Dispõe sobre plano diretor de desenvolvimento } \\
\text { integrado - organização territorial, loteamento } \\
\text { reloteamentos, arruamentos, abertura e } \\
\text { prolongamento de vias, retalhamento de imóveis } \\
\text { em geral e dá outras providências. }\end{array}$ \\
\hline 3349 & $\begin{array}{c}\text { Lei } \\
\text { Ordinária }\end{array}$ & 07101977 & $\begin{array}{l}\text { Regulamenta a atividade comercial nas avenidas } 9 \\
\text { de Julho, Independência e Getúlio Vargas. }\end{array}$ \\
\hline 3563 & $\begin{array}{c}\text { Lei } \\
\text { Ordinária }\end{array}$ & $18 / 12 / 1978$ & $\begin{array}{l}\text { Dispõe sobre plano diretor de desenvolvimento } \\
\text { integrado - organização territorial - zoneamento }\end{array}$ \\
\hline
\end{tabular}




\begin{tabular}{|c|l|l|l|}
\hline 3651 & $\begin{array}{c}\text { Lei } \\
\text { Ordinária }\end{array}$ & $\begin{array}{l}\text { industrial - objetivos, definições, classificação, } \\
\text { subdivisão, uso do solo - e dá outras providências. }\end{array}$ \\
\hline 098 & Decreto & $15 / 04 / 1982$ & $\begin{array}{l}\text { Dá nova delimitação aos perímetros da sede do } \\
\text { município e dos distritos de bonfim paulista e } \\
\text { guatapará. }\end{array}$ \\
\hline 048 & Decreto & $28 / 01 / 1983$ & $\begin{array}{l}\text { Dispõe sobre aprovação de loteamento e dá outras } \\
\text { providências. }\end{array}$ \\
\hline 333 & Decreto & $26 / 12 / 1983$ & $\begin{array}{l}\text { Define e delimita setores e subsetores no distrito } \\
\text { sede do município de ribeirão preto. }\end{array}$ \\
\hline 031 & Decreto & $02 / 03 / 1984$ & $\begin{array}{l}\text { Dispõe sobre aprovação de loteamento e dá outras } \\
\text { providências. }\end{array}$ \\
\hline 033 & Decreto & $20 / 03 / 1986$ & $\begin{array}{l}\text { Dispõe sobre aprovação de loteamento e dá outras } \\
\text { providências. }\end{array}$ \\
\hline & Decreto & $06 / 05 / 1987$ & $\begin{array}{l}\text { Dispõe sobre aprovação de loteamento e dá outras } \\
\text { providências. "propriedade da campanhia } \\
\text { habitacional regional de ribeirão preto - cohab-rp" }\end{array}$ \\
\hline
\end{tabular}

Fonte: Elaboração do autor

Em destaque na tabela, em azul, estão os instrumentos normativos que alteraram o perímetro urbano, aumentando-o. Vale observar que no início esses aumentos se dão de maneira sucessiva e ao longo do tempo são instituídas novas normas que regulavam e estabeleciam critérios mais claros e objetivos de parcelamento (como as lei de 1976, 1977, 1978). Por fim, no período mais recente as menções ao perímetro são geralmente relacionadas à aprovação de novos loteamentos. Salienta-se o decreto 80 de 1987 que aprova loteamento para a companhia habitacional regional (COHAB), mostrando reflexos da política habitacional na fase do $\mathrm{BNH}$ e do sistema financeiro habitacional, ambos marcantes no período tanto para o país como para a região. Percebe-se, portanto, uma lógica cronológica de preparação jurídico-institucional para facilitar o parcelamento do solo, tanto para empreendimentos privados como para a implementação de bairros populares, tento o perímetro urbano papel decisivo na forma dessa expansão. 
4.4.1.1. Lei Municipal n. 1840/1966

Destaca-se também a lei 1840 que altera a disposição do perímetro urbano em 1966

(RIBEIRÃO PRETO, 1966). Em seu conteúdo descreve-se ponto a ponto o contorno da linha perimetral e é interessante notar como os locais de referência utilizados para incluir ou não uma região na zona urbana são geralmente loteamentos de regiões valorizadas, destinados às classes alta e média da cidade, como Jardim Recreio, Ribeirânia, Jardim Itamarati, Jardim Califórnia, Alto da Boa Vista, Vila Ana Maria, Jardim Monte Alegre: DISTRITO DA SÉDE

"Tem início na Estrada de Ferro da Cia Mogiana, paralela ao prolongamento da Avenida Vereador Manir Calil, e segue por aquela, até a divisa do lado opôsto do loteamento do "Jardim Santa Rita", no ponto em que êste confronta com o Hôrto Municipal; daí deflete à direita e segue em direção noroeste, pela divisa do mesmo, até alcançar também as divisas do "Parque Ribeirão Prêto" e por esta até a Avenida Cásper Líbero; daí deflete à esquerda e segue em direção sudoeste pela aludida Avenida até o final do loteamento; daí deflete à direita e segue em direção noroeste pelas divisas ainda do "Parque Ribeirão Prêto", até o córrego Vista Alegre; daí deflete à direita e segue em direção nordeste, pelo referido córrego, até o lado ímpar (ou lado esquerdo) da Avenida dos Bandeirantes (Estrada de Rodagem para Sertãozinho); daí deflete a esquerda e segue em direção oeste-noroeste, pela aludida Avenida, até o córrego Laureano; daí deflete a esquerda e segue em direção oeste, pelo referido córrego, até as divisas do "Jardim Recreio", daí deflete à direita e segue em direção noroeste, indo contornando o aludido loteamento nas direções oeste-noroeste, norte-noroeste e depois nordeste até a Avenida dos Bandeirantes ou seja Estrada de Rodagem para Sertãozinho, atravessando a aludida Estrada segue em direção nordeste, pelas divisas da Faculdade de Medicina, até a Estrada de Ferro da Cia Mogiana; daí deflete à direita e segue em direção sudeste, em linha reta na sequência da rua Miranda, até as divisas do loteamento da "Vila Monte Alegre", aquèm da rua Carlos de Campos; daí deflete à esquerda e segue em direção nordeste, passando pelas divisas dos loteamento da e segue em direção sul-sudeste e depois à direita em direção oeste, contornando o restante do referido loteamento, até o loteamento "Ribeirânia"; daí deflete à esquerda e segue em direção sul-sudeste, depois à esquerda em direção leste, depois à direita em direção sudoeste, depois à direita em direção oeste, depois à esquerda em direção sul e depois à direita em direção oeste, depois à esquerda em direção sul e depois à direita em direção norte-noroeste, contornando todo o restante do loteamento "Ribeirânia", até chegar novamente ao córrego do Retiro; daí deflete à esquerda e segue em direção sudoeste e depois, ligeiramente, à direita em direção oeste, contornando o loteamento do "Condomínio Itamaratí", até a Avenida Presidente Vargas; daí deflete à esquerda e segue em direção sudoeste, pela aludida Avenida, até o extremo do loteamento do "Jardim Helena"; daí defletindo à direita segue em direção oeste, depois à direita, em direção norte, e depois à esquerda, em direção norte-noroeste, contornando os loteamentos do "Jardim Helena", "Vila Ana Maria" e "Jardim California", até o prolongamento da Avenida Independência; daí deflete à direita e segue em direção nordeste, pelo lado par da referida Avenida, indo até os limites do loteamento do "Alto da Boa Vista"; daí deflete à esquerda e segue em direção noroeste, pelas divisas do mesmo, e paralela às ruas Nestor Moreira e Abiílio Rebordões, até a Estrada de Ferro da Cia Mogiana, na confluência com o prolongamento da Avenida Vereador Manir Calil, onde teve início esta delimitação". (grifo nosso) 
À época, muitos loteamentos eram inclusos dentro do perímetro urbano em momento posterior à aprovação do projeto de parcelamento, o que sugere uma postura de anistia da prefeitura em relação às irregularidades urbanísticas em favor dos empreendimentos comerciais . A Lei 2916 de 1974 (RIBEIRÃO PRETO, 1974), que consta na tabela, prevê em seu Artigo $1^{\circ}$ que as construções residenciais de até 80 metros quadrados, no perímetro urbano, sem o licenciamento prévio da administração, tem direito ao registro no departamento competente da prefeitura municipal "desde que estejam conforme ou admitam adaptações às exigências legais, pertinentes à matéria". O mesmo acontecia em São Paulo, que estabeleceu três leis oficializando vias abertas sem registro, em 1953, 1955 e 1962, e uma anistia aos loteamentos e edificações clandestinas em 1968, "representando uma espécie de ordem cronológica-espacial, anistiando os loteamentos do centro para a periferia, inicialmente beneficiando classes mais altas até as mais baixas" (SANTORO, 2012, p.100). A clandestinidade dos loteamentos se tornava cada vez mais comum e evidente em todos os municípios brasileiros, não à toa a década de setenta foi marcada pelas reivindicações por melhores condições urbanas, investimentos em infraestrutura, equipamentos e serviços, que culminaram na criação da Lei Federal de Parcelmento do Solo (6.766/1979). A questão evidencia o perímetro urbano como instrumento vulnerável à captura econômica, sendo utilizado para interferir no mercado produzindo vantagens econômicas a loteadores e construtoras. Permanece a impressão de que o planejamento urbano não consegue se desvencilhar das vontades oligárquicas de determinados setores da cidade, sempre presentes em sua história.

\subsubsection{Decreto 068 de 1973}

A título de curiosidade, vale notar o decreto 068 de 1973 (RIBEIRÃO PRETO, 1973) em que a prefeitura criou o Conselho Municipal de Urbanismo de Ribeirão Preto (posteriormente refundado pela Lei Complementar nº 695 de 1997 e regulamentado pelo Decreto $n^{\circ} 225$ de 1998). De acordo com o art. $1^{\circ}$, o órgão ficaria encarregado de a) - reunir pesquisas, estudos e projetos originários dos diversos órgãos municipais, entidades de classes e associações culturais do Município, preparando e sistematizando a documentação necessária à exata identificação das tendências de expansão urbana e das características sócio-comunitárias da cidade; b) - completar, com base nos estudos mencionados na alínea anterior, e na boa doutrina das modernas teorias de urbanismo, o Plano Diretor de Urbanização; c) - elaborar o Projeto do Código de Obras do Município, promovendo todas as medidas necessárias à sua posterior implantação; d) - elaborar o Plano de Zoneamento 
Urbano; e) - auxiliar na elaboração dos planos municipais de habitação; f) - realizar todas e quaisquer atividades relacionadas com o estudo de assuntos ligados à racional urbanização do município, mesmo que não arrolados especificamente nas alíneas anteriores.

O rol de competência atribuído ao conselho espanta pela grande possibilidade de participação nas decisões urbanísticas, inclusive na determinação dos parâmetros de expansão urbana. Entretanto, no período o órgão tinha um perfil eminentemente técnico, criado para atender "à imperiosa necessidade de levar a efeito estudos referentes ao Plano Diretor de Urbanismo;", conforme disposto na introdução à lei que o instituiu.

Além disso, a participação do conselho não era aberta a todos vez que, pela lei, “o COMUR será constituído por pessoas de notório saber e experiência dotados de alto espírito público, designados pelo Prefeito Municipal” (art. $2^{\circ}$ ). Bem como "a presidência do COMUR caberá a um dos membros do Conselho, escolhido pelo Prefeito Municipal.”(art. $\left.4^{\circ}\right)$

\subsubsection{Regulamentação do uso e ocupação do solo (1976-1978)}

Em 1976 a Lei 3236 dispõe sobre o plano diretor de desenvolvimento integrado e regula a organização dos loteamentos, reloteamentos, arruamentos, abertura e prolongamento de vias, retalhamento de imóveis em geral. Entretanto no ano seguinte a lei é revogado por um novo regramento (lei $n^{\circ} 3346 / 77$ ), com disposições bastante similares e mais minuciosas. Em seu art. $1^{\text {o }}$ são detalhados os critérios para definição da área urbana, rural e expansão urbana, sendo essa última situada em até no máximo de 2.000 (dois mil) metros além do limite do perímetro urbano, o que parecia ser uma estratégia bastante favorável ao crescimento contíguo da expansão urbana. Interessante notar que o dispositivo antecipa algumas disposições posteriormente estabelecidas pela lei. 6766 de 1979, como a exigência de se reservar áreas para destinações institucionais nos projetos submetidos à aprovação de loteamento, com requisito mínimo de 5\% ("área reservada a fins específicos de utilidade pública tais como educação, saúde, cultura e esportes;”). Ainda, o art. 15 determina que após a aprovação das autoridades sanitárias e militares, o proprietário assinará termo de compromisso no qual se obrigará: "a transferir como bem de uso comum do povo por doação sem quaisquer ônus para o município as áreas verdes e as vias, bem como transferir, mediante escritura pública, por 
doação à Prefeitura, como bem dominial, as áreas destinadas a fins institucionais"; (RIBEIRÃO PRETO, 1977).

No mesmo ano a Lei n. 3.349, de 07 de outubro de 1977 faz importantes alterações no planejamento da região sul, definindo corredores comerciais e novas vias de expansão viária (RIBEIRÃO PRETO, 1977):

Art. $1^{\circ}$ Em toda a extensão da Avenida 9 de Julho, na Avenida Independência desde o inicio até a rua Júlio Prestes e na Avenida Getúlio Vargas após a Avenida Antônio Diederichsen fica liberada a atividade comercial, na forma prevista por esta

Art. $2^{\circ}$ Nas áreas fixadas pelo artigo anterior, poderão instalar-se estabelecimentos comerciais das seguintes categorias:

a) comercio de consumo excepcional (raro e requintado);

b) serviços profissionais;

c) serviços pessoais de saúde e de higiene;

d) serviços de escritório e negócio.

Parágrafo Único - No anexo a esta lei, está a lista de atividades de categorias de que trata este artigo, sendo a sua numeração taxativa, não admitindo a inclusão de qualquer outra atividade. (grifo nosso)

A regulação de uso e ocupação do solo em conjunto com as mudanças propostas por essa lei foram determinantes para o perfil de crescimento territorial que se instalou da cidade desde então, como se verá a seguir.

\subsubsection{Fundação do Ribeirão Shopping e o Novo Vetor de Expansão Urbana}

O Ribeirão Shopping foi inaugurado em 1981, estrategicamente colocado na região centro-sul da cidade, cuja renda per capita anual era de aproximadamente cinco mil dólares e que possuía em média 1 automóvel para cada 4 habitantes (GARREFA, 2004). Segundo o arquiteto Fernando Garrefa, o empreendimento se diferenciava espacialmente dos equivalentes paulistanos, que geralmente eram instalados em áreas urbanizadas e bastante próximas dos mercados consumidores. A região onde hoje se localiza o Ribeirão Shopping fazia parte da fazenda Nova Aliança, portanto fundado nas zonas limítrofes rural-urbano. Curioso notar que os bairros de classe média e alta que se formaram na sequência sul do centro comercial também levam o nome da fazenda (Bairro Nova Aliança e Nova Aliança Sul) o que chama atenção para a recorrente relação entre os grandes proprietários de terra e a produção elitizada do espaço urbano em Ribeirão Preto.

Ainda que estivesse em uma região pouco urbanizada, o Shopping e seu entorno eram acessíveis pela Avenida Presidente Vargas - importante eixo viário da zona sul - e se situava a menos de um quilômetro do anel viário. "Pode-se considerar sua localização como 
bem sucedida, pois conciliava diversos fatores tais como o preço bem mais baixo da terra na zona rural, a proximidade do centro da cidade (apenas quatro quilômetros) e do anel viário e sua inserção no vetor sul da cidade que, em 1981, dava sinais claros de expansão" (GARREFA, 2004, p.5). Em 2004, por exemplo, depois de sucessivas expansões o centro comercial já atendia a uma população estimada em quatro milhões de habitantes, residentes em cerca de duzentas cidades, contidas em um raio de influência que atinge inclusive regiões do estado de Minas Gerais.

Dois anos depois, o planejamento decorrente da lei $\mathrm{n}^{\circ} 4.375$ de 1983 determinou a ampliação da avenida Presidente Vargas em 10km, em direção ao setor sul do Anel Viário, e alterou o zoneamento da região ao longo da via para uso misto. Em 1985 a Lei no 4.709 permitiu e regulou a abertura de novos loteamentos na região limítrofe do contorno sul do Anel Viário (art. $3^{\circ}$-4). Essas mudanças efetuadas pelo poder público na região sul criaram grandes corredores de comércio e serviços, interligaram a estrutura viária local e proporcionaram comodidades tanto para o Shopping quanto para os loteamentos que surgiram em sua órbita, valorizando a terra que antes era lindeira à zona rural. (FIGUEIRA, 2013, 144-146).

A figura da urbanização ancorada por um centro de compras é bastante simbólica para o período, marcado pela ascensão da financeirização da terra e pela liberalização do mercado mundial. Em "Guerra dos Lugares” a urbanista Raquel Rolnik (2015) argumenta que a nova ordem econômica global transformou as cidades em verdadeiros campos de batalha financeiros, onde vale tudo pela atração de investidores. Dessa forma os gestores mobilizam desde marketing "cool” para promover cidades mundo afora até a utilização de recursos públicos para criar bolsões de atratividade, provendo de infraestrutura e norteando o processo pelos shoppings centers, “corporate towers" e hotéis. A transformação da cidade em produto vendável no mercado financeiro gera novas prioridades de gastos, relegando o bem-estar social a segundo plano ("se sobrar"). Prova disso são os megaeventos esportivos, que demandam dinheiro público em obras com a promessa de colocar a cidade nos holofotes dos investimentos, como foi o caso do Rio de Janeiro nos Jogos Olímpico (SWYNGEDOUW; MOULAERT; RODRÍGUEZ, 2002)

O Resultado dessa política é a constituição de um território recortado do conjunto da cidade, construído e gerenciado sob a lógica da extração de renda e da promoção do consumo, gerido de forma paralela à gestão geral da cidade, que vai aos poucos expandindo os "enclaves" residenciais e comerciais - como condomínios fechados e shopping centers - em direção a pedaços inteiros de cidade, "possibilitando a atores privados o exercício de 
governo e, portanto, ampliando a zona de indefinição entre o privado e o público e reconfigurando a ordem política” (BENTES, 2011)

Figura 7 - Eixo Sul e as mudanças provocadas pela L. 3349 de 1977.

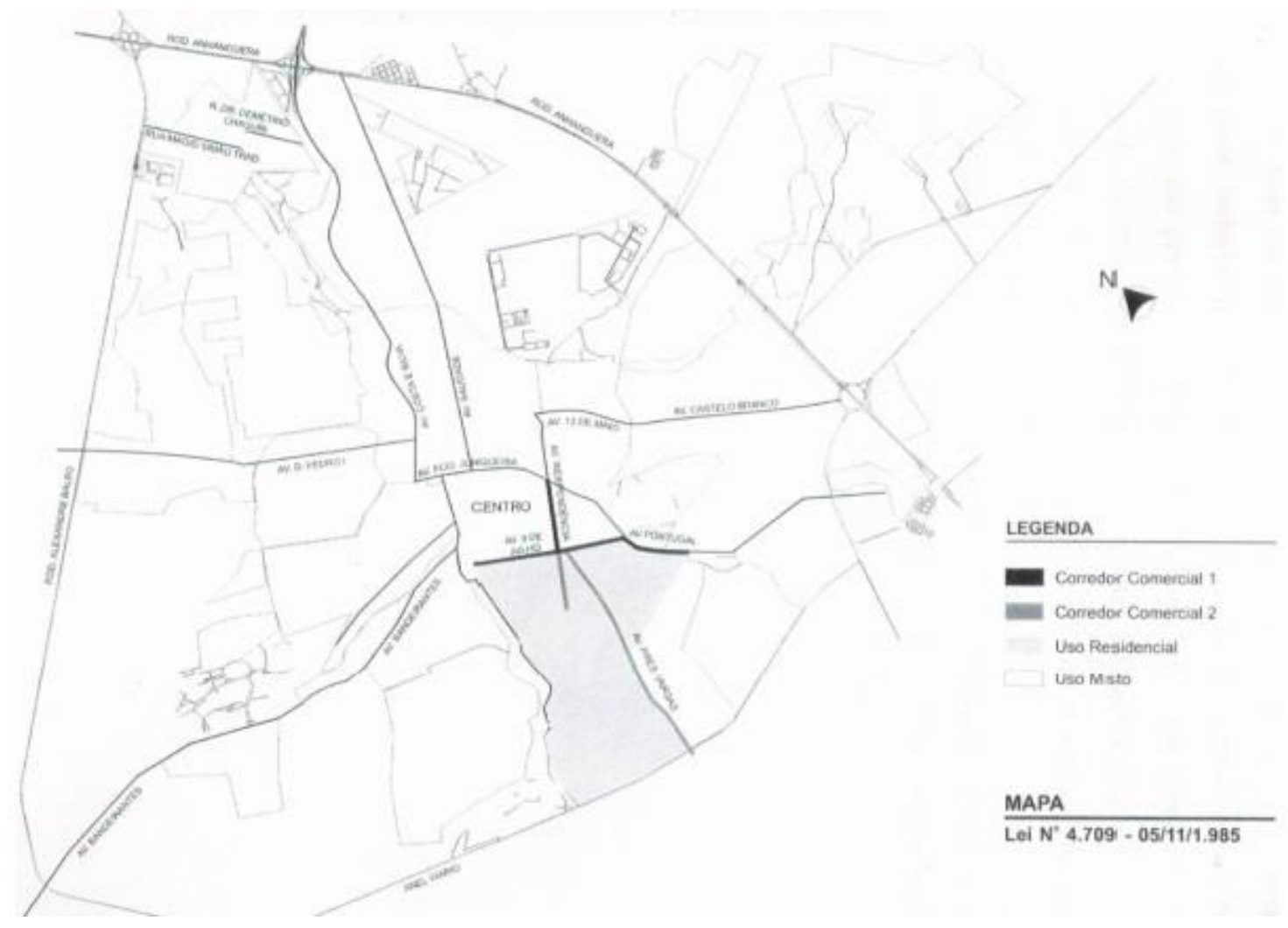

Mapa das principais alterações no parcelamento, uso e ocupação do solo da zona Sul de Ribeirão Preto, fruto das determinações da Lei n 3.349, de 07 de outubro de 1977, pela Prefeitura Municipal. Fonte: FIGUEIRA, 2013, p. 144.

4.5 Ribeirão Preto no período de redemocratização (1988-2017) 
Ribeirão Preto transitou do século XX para o XXI mantendo a tendência de crescimento demográfico, atingindo cerca de 674.405 habitantes em 2016, segundo projeção do IBGE. A cidade figura entre as 8 maiores cidades do Estado de São Paulo e entre as 30 maiores cidades do País (IBGE, 2014), com Produto Interno Bruto de R\$ 28.087.397,00 e PIB per capita de R\$ 42.682, 19, ambos em 2014.

Ainda, segundo o levantamento técnico do novo Plano Direitor (Ribeirão Preto, 2014) o interior do Estado de São Paulo ultrapassou no ano de 2012 a Região Metropolitana de São Paulo e ganhou o posto de maior mercado consumidor do País. "Esse resultado consolida a tendência de desconcentração do crescimento econômico observada nos últimos cinco anos, com a perda de participação das capitais dos Estados no consumo total das famílias brasileiras"

Entretanto, apesar da pujança econômica que a cidade demonstra no período os níveis de desigualdade social continuaram igualmente impressionantes, com índices Gini de 0,53 em 1991; 0,56 em 2000 e 0,54 em 2010 ${ }^{38}$. A enorme disparidade, as migrações pendulares provocadas pelo trabalho da lavoura de cana foram somadas à paralização da política habitacional nos anos 90, o que fez surgir uma série de assentamentos precários no município. É o que se observa nos mapas:

\footnotetext{
38 Brasil.DATASUS Tecnologia da Informação a $\quad$ Serviço do http://tabnet.datasus.gov.br/cgi/ibge/censo/cnv/ginisp.def
} 
Figura 8 - Renda Per Capita nos setores censitários de 2000.

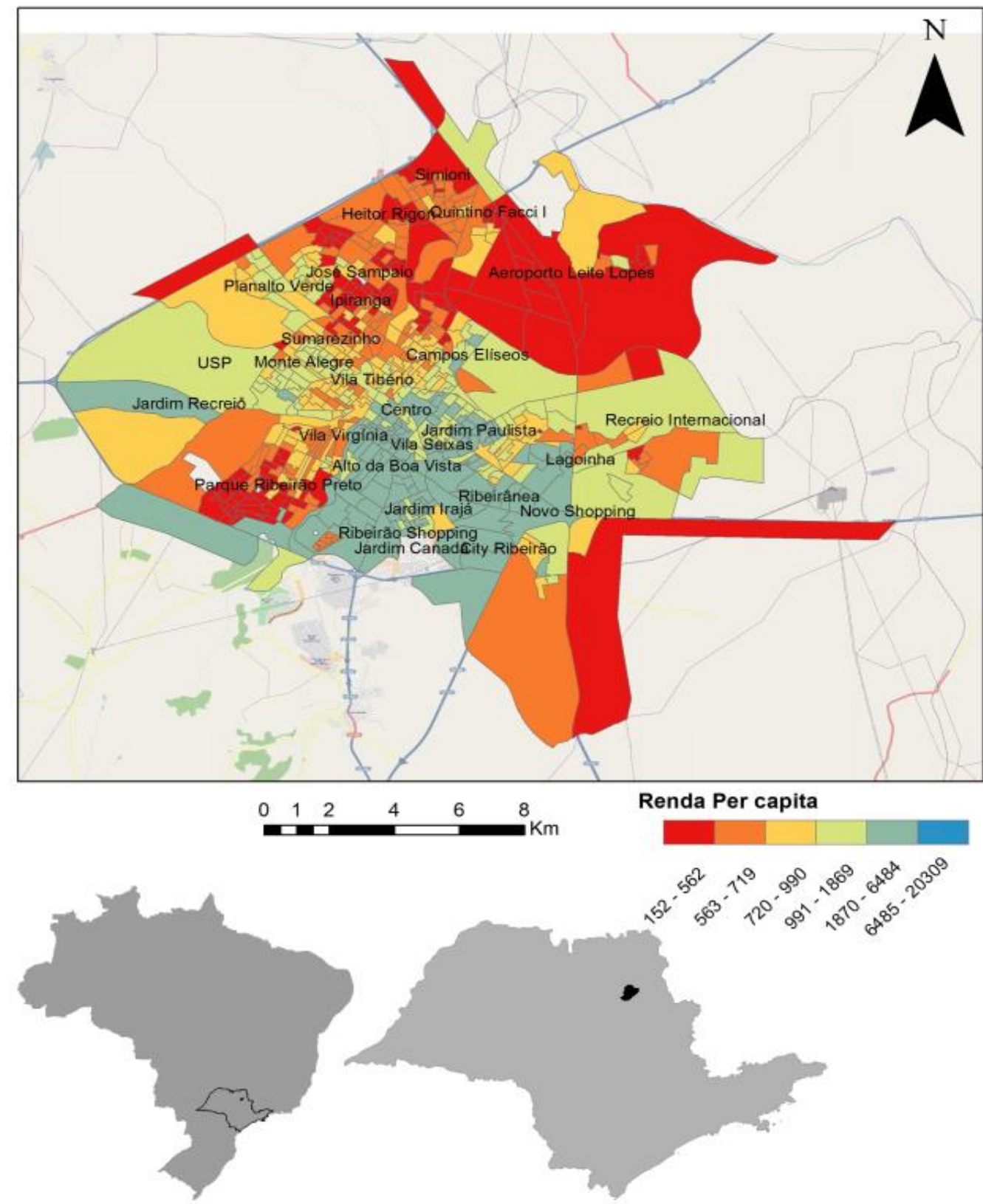

Fonte: IBGE. Autor: André Celarino, 2013. 
Figura 9 - Renda Per Capita nos setores censitários de 2010.
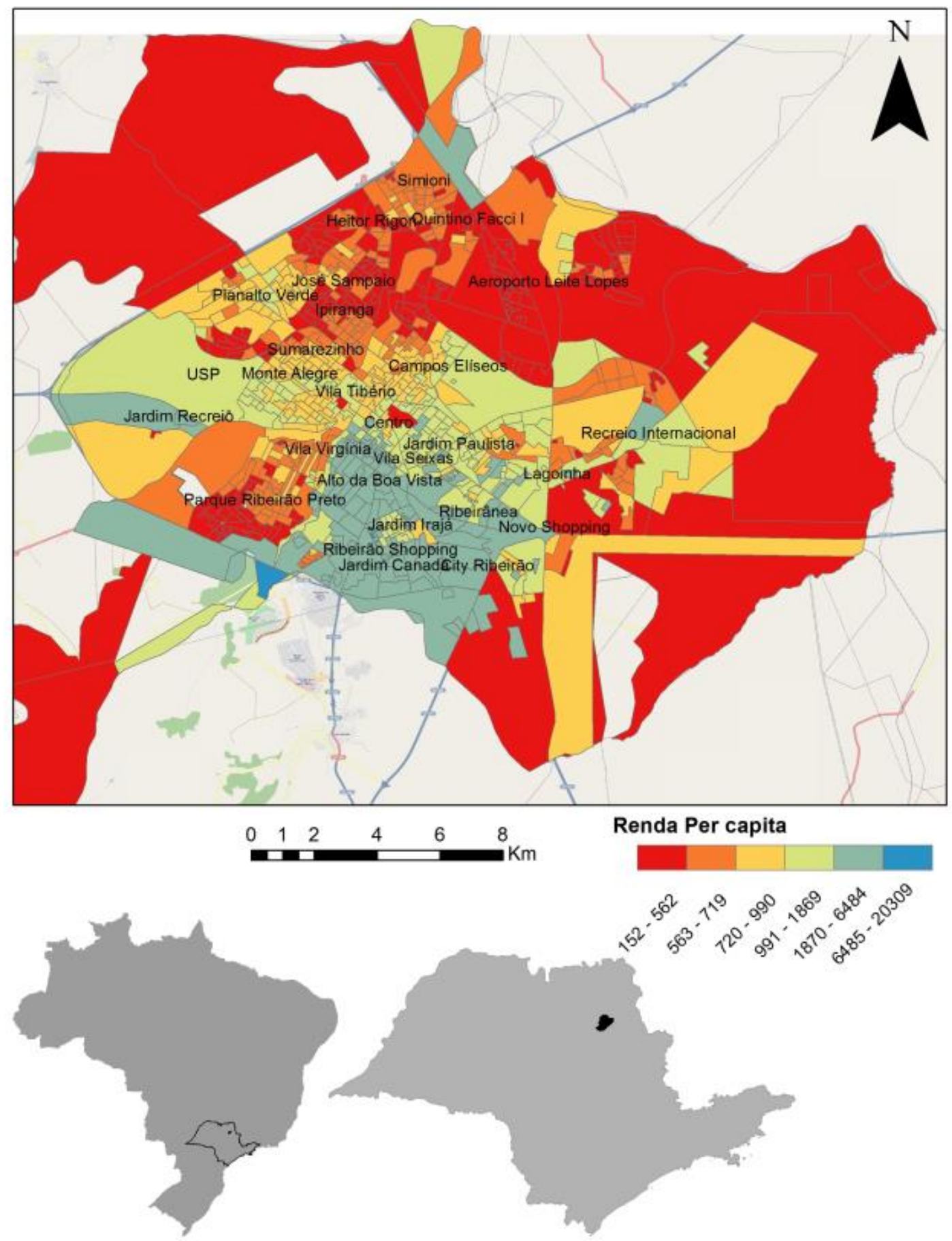

Fonte: IBGE. Autor: André Celarino, 2013.

Foto 10 - Divisão racial do município de Ribeirão Preto em 2010 

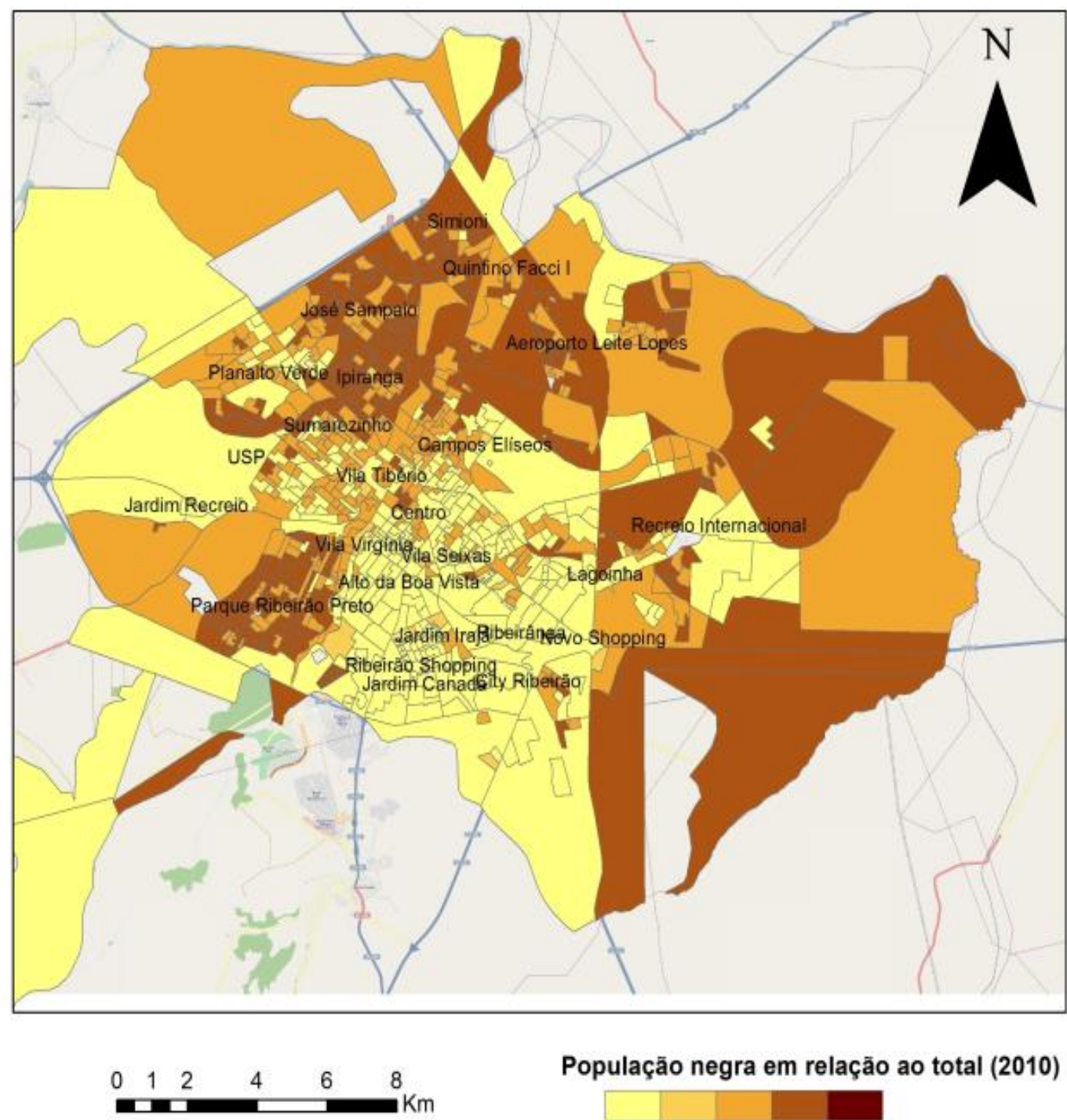

População negra em relação ao total (2010)

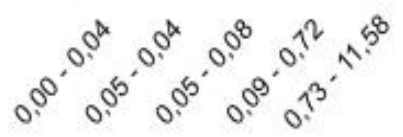

Fonte: IBGE (2010). Autor: André Celarino, 2013.

Foto 11 - Proporção de pessoas com 5 anos ou mais alfabetizadas em relação à população total por setores censitários (2010) 

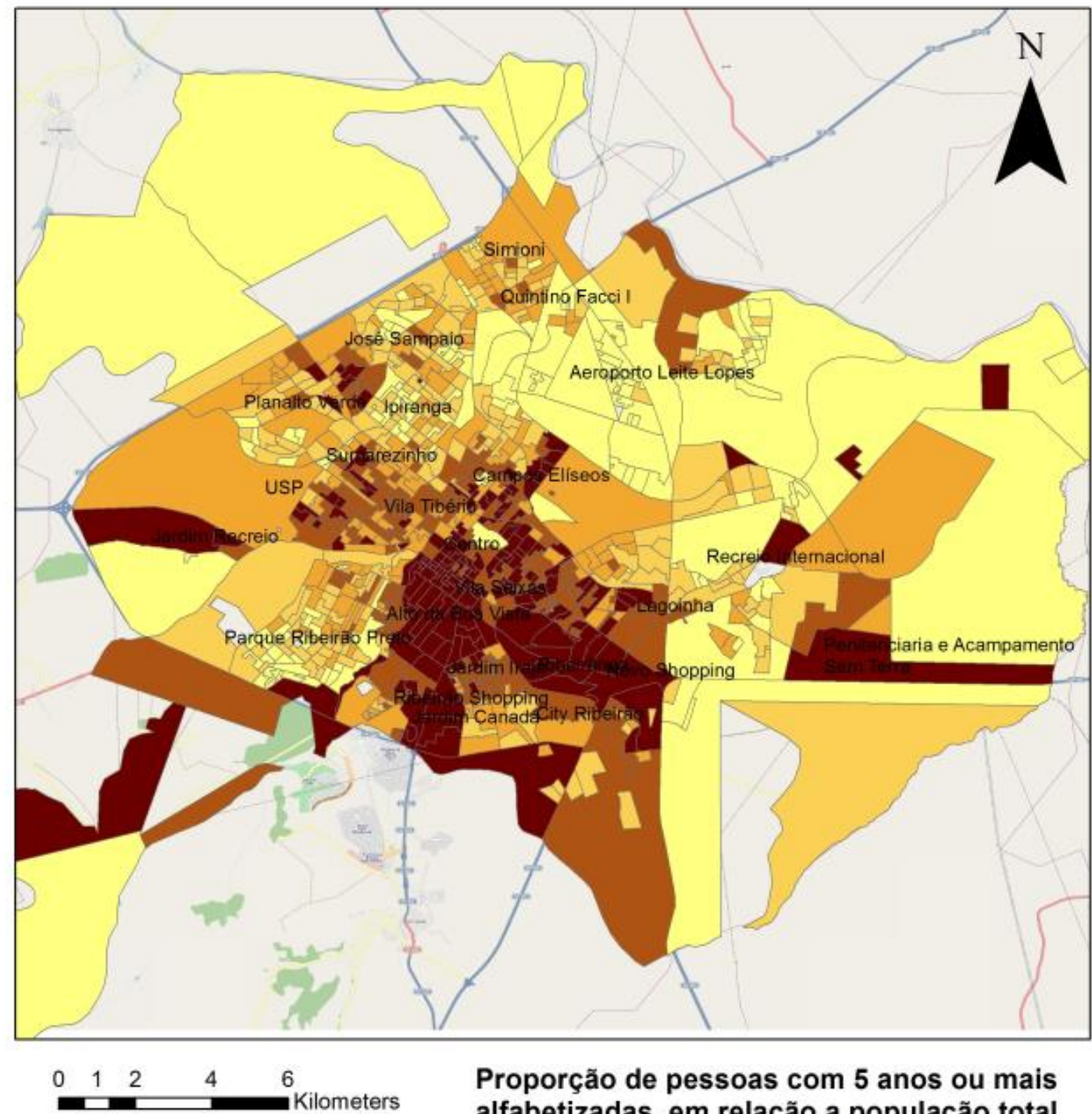

Proporção de pessoas com 5 anos ou mais alfabetizadas, em relação a população total por setores censitários, 2010.

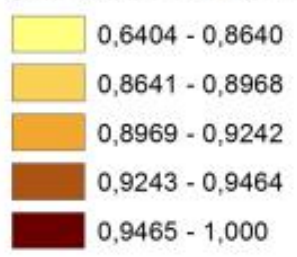

Fonte: IBGE. Autor: André Celarino, 2013.

Conforme se extrai das informações dos mapas, a cidade de Ribeirão Preta é nitidamente cindida por critérios de classe e raça, sendo o setor norte predominantemente pobre, negro, e com pouca escolaridade, enquanto o sul é branco, rico e instruído. Sabe-se que essa fragmentação social não é exclusividade do município, sendo característica 
comum a todo o Brasil. Entretanto, tendo o maior índice Gini da região administrativa, Ribeirão Preto deixa subentendido que seu passado oligárquico ainda determina as feições da sociedade moderna. A segregação espacial também foi construída a partir dessa configuração histórica, sendo reforçada por políticas públicas higienistas no começo do século XX. Passados mais de 100 anos dessas configurações segregacionistas a cidade ainda sustenta características espaciais semelhantes, sendo que agora novas formas de ocupação em condomínio e o contexto da financeirização do território tem tornado o encastelamento social ainda mais intenso:

Foto 12 - Relação entre Shoppings, Infraestrutura Viária e a Valorização do Solo

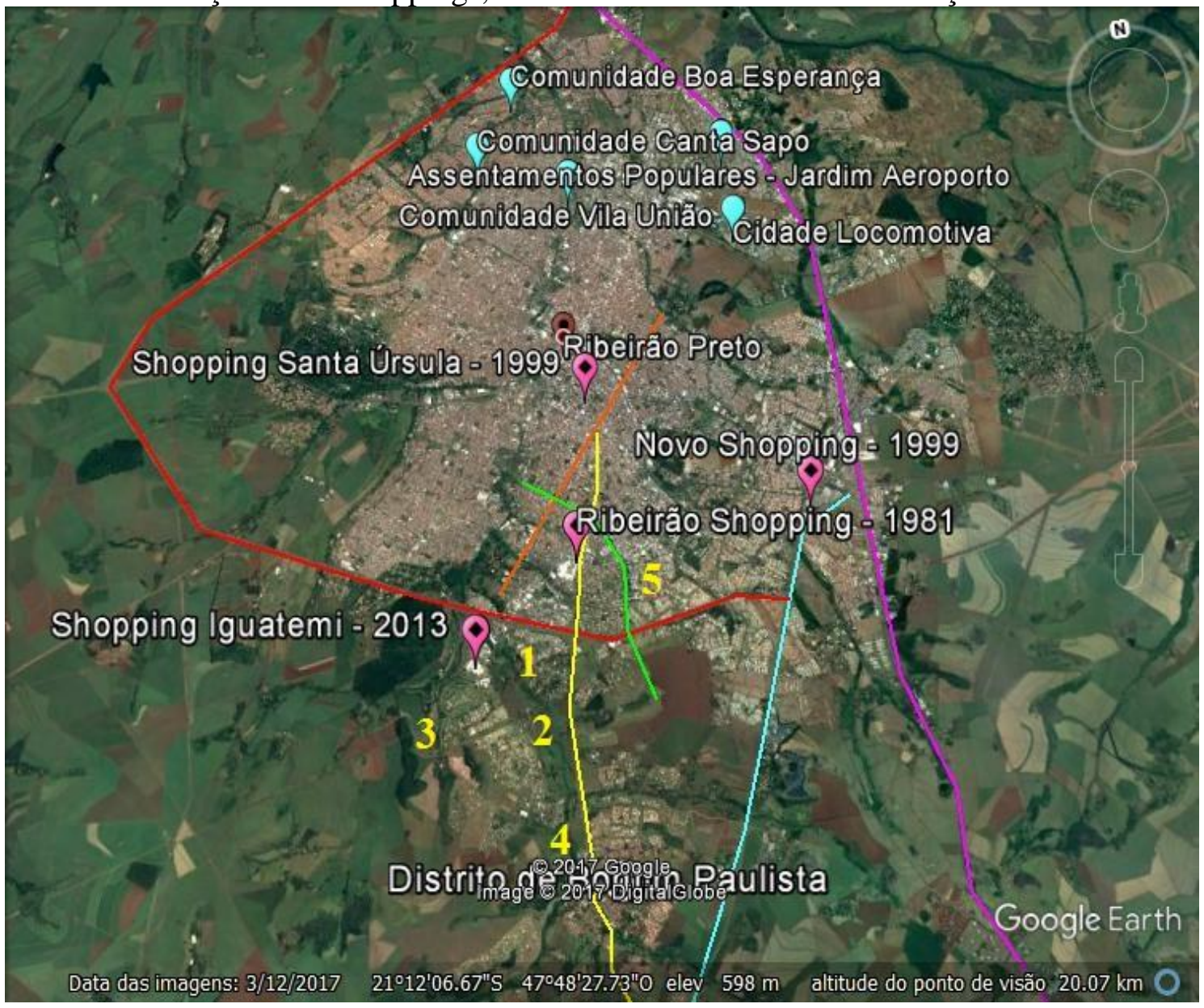

Fonte: Elaboração do autor.

a) Vias: Na imagem é possível identificar a malha de infraestrutura viária, tanto de estradas Estaduais quanto de vias municipais: rodovia Prefeito Antônio Nogueira - SP 322 (Vermelho); Rodovia Antônio Machado Sant'anna - SP 255 (Azul claro); Rodovia Anhanguera - SP 330 (Rosa); Avenida João Fiúsa (verde); Avenida Getúlio Vargas e Rodovia José Fragonezi (amarelo) - 
b) Condomínios e Loteamentos: Os números elencados no mapa correspondem à localização dos principais complexos habitacionais privados de alto padrão na zona sul: Nova Aliança Sul (1); Royal Park (2); Complexo do Golf (vários condomínios, 3); Alphaville (4); Região da Fiúsa (5).

c) Assentamentos Populares: os ícones em azul claro apontam a localização de alguns dos principais pontos de vulnerabilidade urbana na cidade, sendo o maior deles o conjunto de ocupações em torno do aeroporto Leite Lopes. A grande maioria dos bairros precarizados estão no setor norte da cidade.

O mapa permite sobrepor a localização dos Shopping Centers, dos Condomínios de Alto Padrão, dos Assentamentos precários e a malha de vias ampliadas, construídas ou interligadas à época da lei no 4.375 de 1983 e 4.709 de 1985. É possível constatar um padrão de expansão urbana onde: 1 . Os shoppings são colocados em zonas rururbanas limítrofes e de baixo valor, sempre em direção ao sul-sudeste (com exceção do Shopping Santa Úrsula no bairro Higienópolis); 2. A prefeitura mobiliza o planejamento urbano para viabilizar a instalação desses empreendimentos, seja alterando o regramento urbanístico, seja investindo em infraestrutura (vide as leis acima, criadas com esse intuito), seja fazendo "vista grossa" para as irregularidades urbanísticas dos empreendedores. 3. A terra ao redor do Shopping, (ou do ponto coemrcial "âncora" elegido para a colonização do espaço) é loteada e partilhada entre as construtoras.

Gráfico 2 - Total de Despesas Municipais em Urbanismo (Ribeirão Preto) 


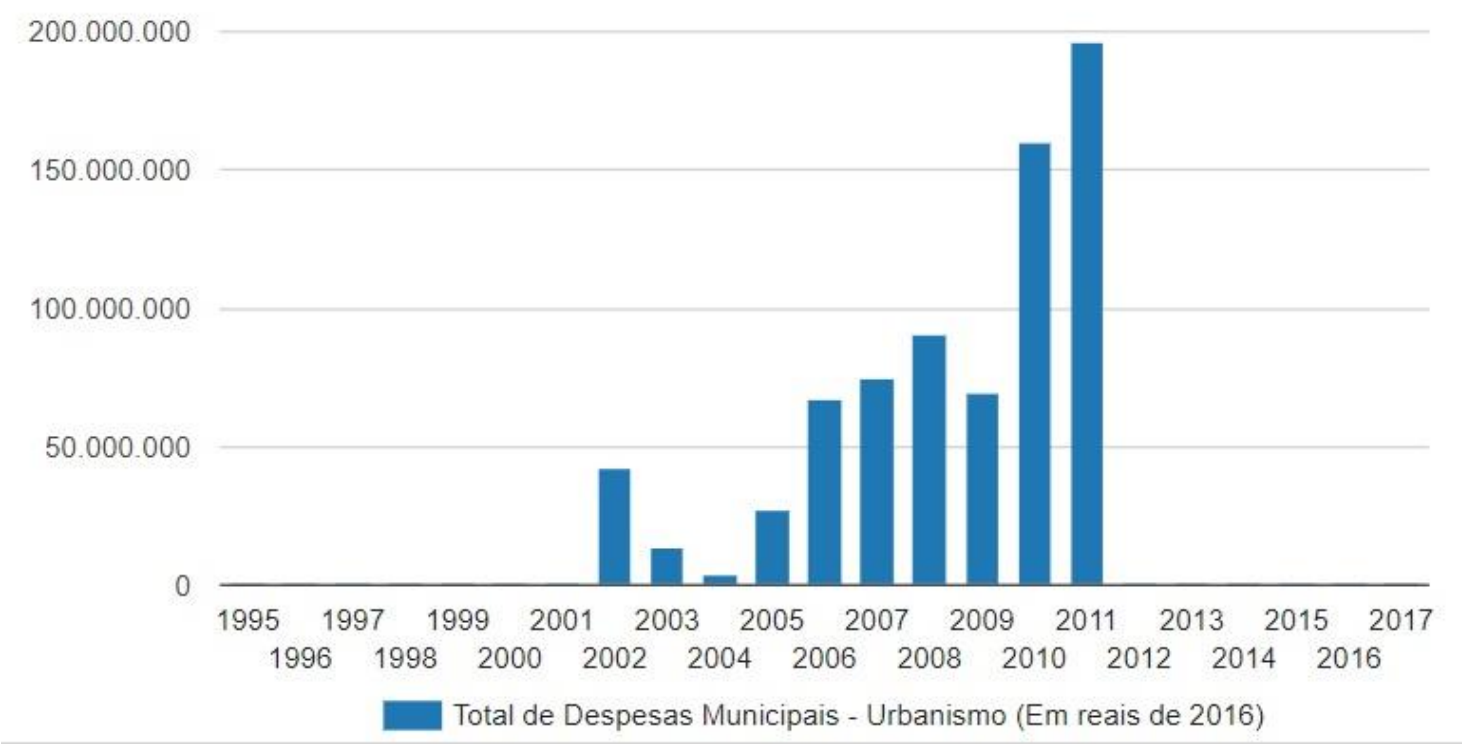

Fonte: Fundação ${ }^{39}$ SEADE, 2016.

Gráfico 3 - Total de Despesas Municipais (Em Reais de 2016)

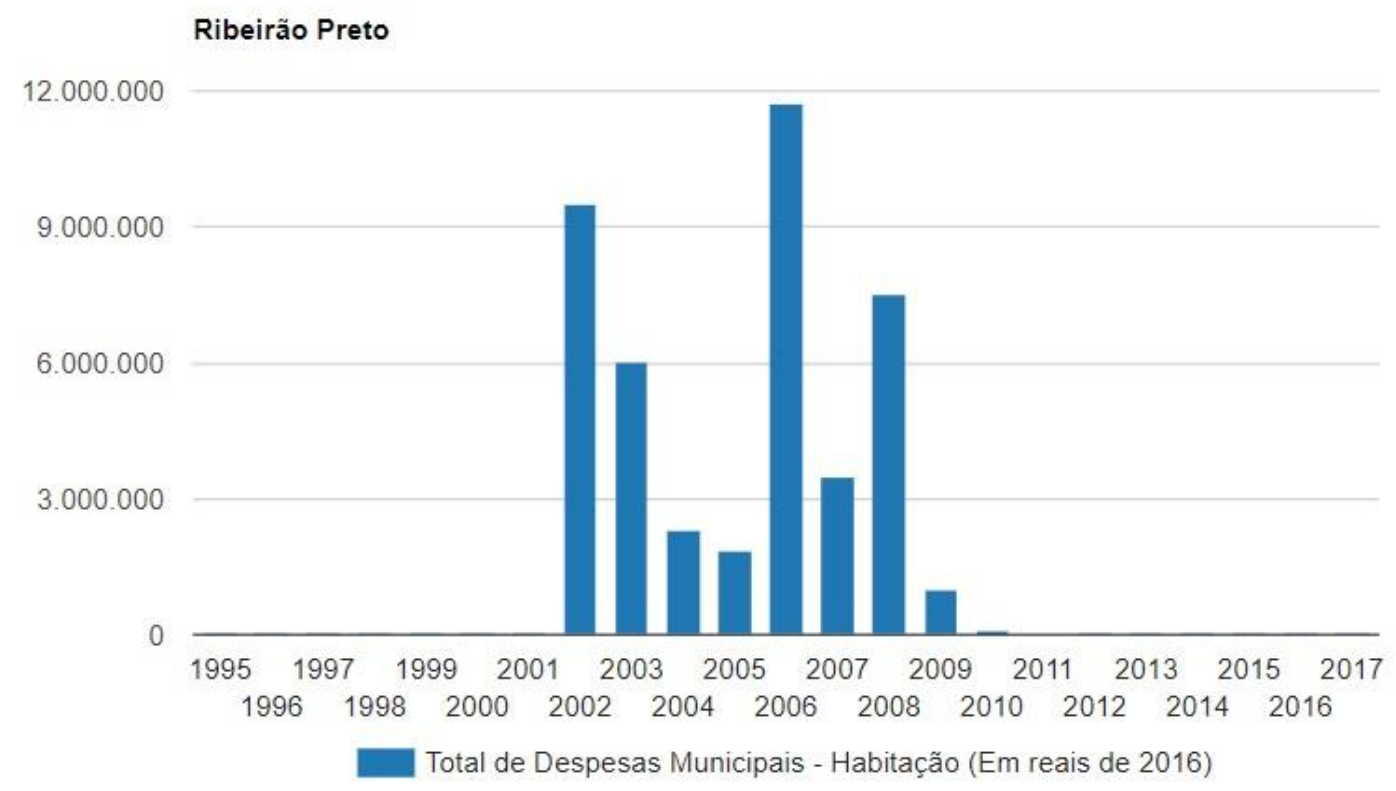

Pelas tabelas extrai-se que o Poder Público Municipal de Ribeirão Preto vem aumentando consideravelmente seus gastos com serviços urbanos, transporte coletivos e urbanos e infraestrutura em geral. Entretanto, o mesmo não se constata em relação às

\footnotetext{
${ }^{39}$ Obs.: Contas da Despesa Municipal em Urbanismo em Vigor a partir de 2002. O critérios para avaliar InfraEstrutura Urbana consideram: sistema viário, esgotamento e água (15451) Serviços Urbanos, (15452), Transportes Coletivos Urbanos, (15453) Fonte: Lei $n^{\circ} 4.320 / 64$ e Portaria MOG no 42/99. Ministério da Fazenda/Secretaria do Tesouro Nacional. Fundação Seade. Pesquisa Municipal Unificada - PMU.
} 
despesas decorrentes das ações de planejamento, coordenação e execução, de forma integrada, de programas de política habitacional (planejamento, promoção e construção de residências, a fim de satisfazer as necessidades de habitação nas cidades e no meio rural). Vale notar que o município tem um déficit habitacional de aproximadamente 60.000 imóveis, segundo a prefeitura ${ }^{40}$, o que dispensa a hipótese de que não haveria necessidade de investir no setor. Sendo assim, levando em conta o histórico apresentado de investimentos públicos em "avenidas imobiliárias" bem como a promiscuidade envolvendo as administrações municipais e as construtoras (vide caso Sevandija) é possível especular que os recursos públicos não estão sendo priorizados na construção de uma cidade plural, nem respeitando os princípios da política urbana nacional, como a moradia digna e direito à cidade.

\subsubsection{O Plano Diretor de 1995 e suas leis complementares (LC. 1.573/03 e LC. 2.157/07)}

No ano de 1995 foi aprovada a Lei Complementar n. 501, que instituía o Plano Diretor Participativo do município. No contexto da recente redemocratização, houve grande mobilização por parte de entidades e conselhos municipais com a elaboração do projeto de Lei, dentre eles o COMUR. Havia, portanto, a expectativa de se promover um desenvolvimento democrático, socialmente justo e ambientalmente equilibrado, contando pela primeira vez com a participação popular. Tinha-se a impressão de que as leis vigentes até então promoveram algum controle sobre a conformação e o adensamento urbano, todavia a cidade carecia de um projeto urbanístico mais amplo, de longo prazo, em que se estabelecessem diretrizes de expansão direcionados e vinculantes (FIGUEIRA, 2013, p. 146). Entretanto, o plano diretor manteve a tendência anterior de priorizar o vetor de expansão para a Zona Sul, levando em conta as facilidades promovidas pelos investimentos anteriores em infraestrutura (RIBEIRÃO PRETO, 1995):

\footnotetext{
ARTIGO $8^{\circ}$ - O setor sul, limitado pelo Vale do Ribeirão Preto, Vale do Retiro do Saudoso e pela Rodovia Antônio Machado Sant'Anna (SP-255), e parte do Setor Oeste limitado pelo Vale do Ribeirão Preto, pela Avenida dos Bandeirantes e pela divisa do Município a Oeste, constitui o vetor de crescimento da área urbanizada de Ribeirão

$\S 1^{\circ}$ - Os setores da cidade citados no "caput" deste artigo são aqueles definidos
}

\footnotetext{
${ }^{40}$ www.ribeiraopreto.sp.gov.br/J332/noticiaWebImprimir.xhtml?id=37140
} 


\begin{abstract}
pelo Decreto Municipal $\mathrm{n}^{\circ}$ 333, de 26 dezembro de 1983.
$\S 2^{\circ}$ - O eixo estruturado pelo prolongamento dos corredores comerciais formados pelas avenidas Independência, Presidente Vargas e Adelmo Perdizza constitui o vetor principal da expansão urbana do Município.

$\S 3^{\circ}$ - Os eixos estruturados pela Rodovia Antônio Machado Sant'Anna e sudeste e pelas avenidas Casper Líbero e Patriarca a sudoeste, constituem os vetores secundários da expansão urbana do Município.
\end{abstract}

Ainda que houvesse uma justificativa técnica para essa decisão, é possível especular que ela tenha se dado em benefício do grande interesse financeiro e imobiliário da cidade, vez que já havia esforços anteriores do poder público em transformar a área em polo de valorização, consolidando em torno do eixo sul do anel viário.

No que tange às menções diretas ao perímetro urbano é importante notar o art. 14I, que define a linha perimetral entre seu rol de "instrumentos urbanísticos" complementares da política de produção e organização do Espaço. É a primeira vez que essa nomenclatura é usada para determinar o perímetro urbano, tirando-o da condição de mera divisória técnica e alçando-o para o de ferramenta de política territorial. Além disso, como o Plano Diretor demanda participação popular, tem-se pela primeira vez a possibilidade de intervenção dos administrados na demarcação da zona urbana. $\mathrm{O}$ artigo 153, por sua vez, determina que a Lei de Zoneamento - Uso e Ocupação do Solo, seja apresentada de forma integrada, com a revisão da legislação existente, e a devida consolidação da Lei 5218/88, que estabelece o Perímetro Urbano, e das leis complementares de expansão urbana $n^{\circ}$ s $173 / 92$ e 161/92, que dão nova limitação ao perímetro urbano e alteram a zona de expansão urbana, respectivamente;

Mesmo com tantos detalhes, havia a urgência de aprovar imediatamente essa lei visto que o município superava largamente 20 mil habitantes e precisava cumprir a determinação constitucional de planejamento. De acordo com Tânia Figueira (2013), a pressa resultou em determinações genéricas para a cidade, o que resultou em uma séria de dispositivos normativos posteriores que viriam dar a regulamentação necessária às lacunas do Plano Diretor de 1995. Ao longo dos anos 2000 formou-se um mosaico de leis urbanísticas complementares àquele texto foi aprovado, dentes elas, a Lei $\mathrm{n}^{\circ} 1.616$, de 2004, que instituiu o Código do Meio Ambiente, "dispôs sobre o Sistema Municipal de administração da atualidade, proteção, controle e desenvolvimento do meio ambiente e uso adequado dos recursos naturais, sobre os instrumentos da política ambiental e estabeleceu normas gerais para a administração da qualidade ambiental do município" (FIGUEIRA, 2013, p.145). 
A promulgação do Estatuto da Cidade em 2001, deu início à primeira revisão do Plano Diretor do Município em 2002, culminando na Lei $\mathrm{n}^{\circ}$ 1.573/03 que readequou a lei de 1995 à exigências da política urbana nacional, conforme consta da Justificativa Técnica do Projeto de Lei da $2^{\mathrm{a}}$ revisão:

"Ribeirão Preto inicia seu processo de revisão em 2002, finalizando-o em novembro de 2003 com a promulgação da Lei ${ }^{\circ}$ 1.573/03. Naquele momento as audiências públicas aconteceram com o intuito de apresentar as inserções obrigatórias pelo Estatuto da Cidade ao Plano Diretor definido pela Lei $n^{\circ}$ 501/95. Com isso, esta última não foi revogada e ambas passaram a existir concomitantemente de forma complementar" (RIBEIRÃO PRETO, 2014, p. 11).

Em 2007 é promulgada a lei 2.157, que buscava readequar as determinações sobre parcelamento, uso e ocupação do solo com bases na Lei 10.257/2001 - Estatuto da Cidade e a Lei Complementar 501 - Plano Diretor. A partir da promulgação desta lei foram revogadas as disposições em contrário, notadamente as Leis Municipais 3346/77, 4889/86, $5058 / 87,5164 / 87,5218 / 88,5685 / 90,8681 / 00$, bem como suas respectivas leis complementares.

Vale lembrar que em função de uma Ação declatória de inconstitucionalidade $(\text { ADIN })^{41}$ contra a Lei. 2.505 de 2012, que disciplinava parcelamento, uso e ocupação do solo em Ribeirão Preto, as determinações vigentes acerca do perímetro urbano e de expansão urbana são baseadas na lei 2.157 de 2007.

Vide mapa:

${ }^{41}$ TJ-SP - Direta de Inconstitucionalidade : ADI 20983604820148260000 SP 2098360-48.2014.8.26.0000 


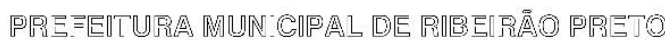

A D M I N I S T R A G Ã O DÁRCY VERA

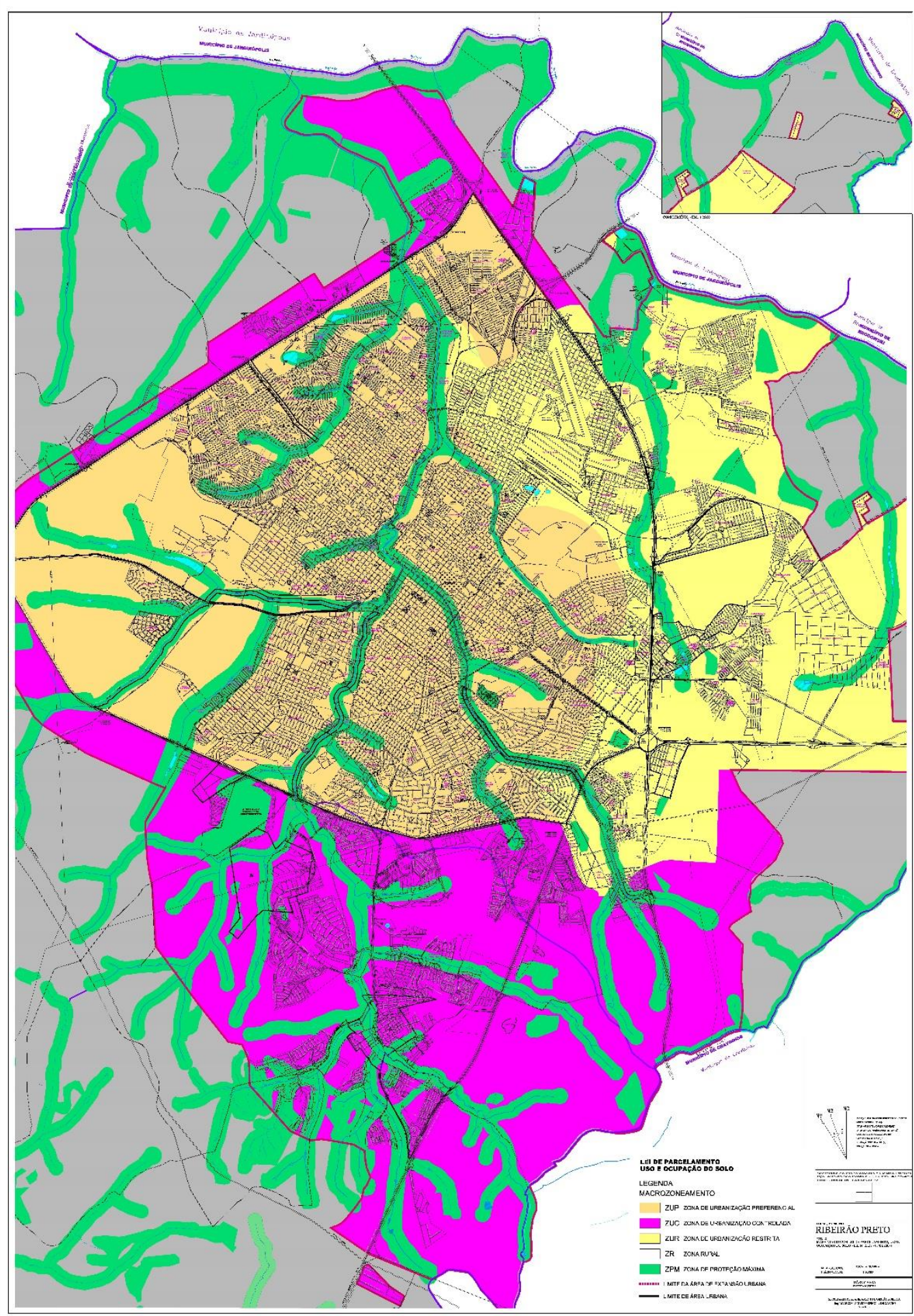

Figura 13 - Macrozoneamento de Ribeirão Preto (2007). Fonte: RIBEIRÃO PRETO, 2007. 


\subsection{Lei Complementar 2.505 de 2012: ADIN.}

Em 2012 foi feita uma revisão da LC 2157/07 onde se aprovou a Lei Complementar 2.505 de 18 de janeiro de 2012 que dispunha sobre o parcelamento, uso e ocupação do solo no Município. "Revogando as disposições em contrário, notadamente a Lei Complementar $\mathrm{n}^{\circ}$ 2157/2007 e suas respectivas leis complementares.
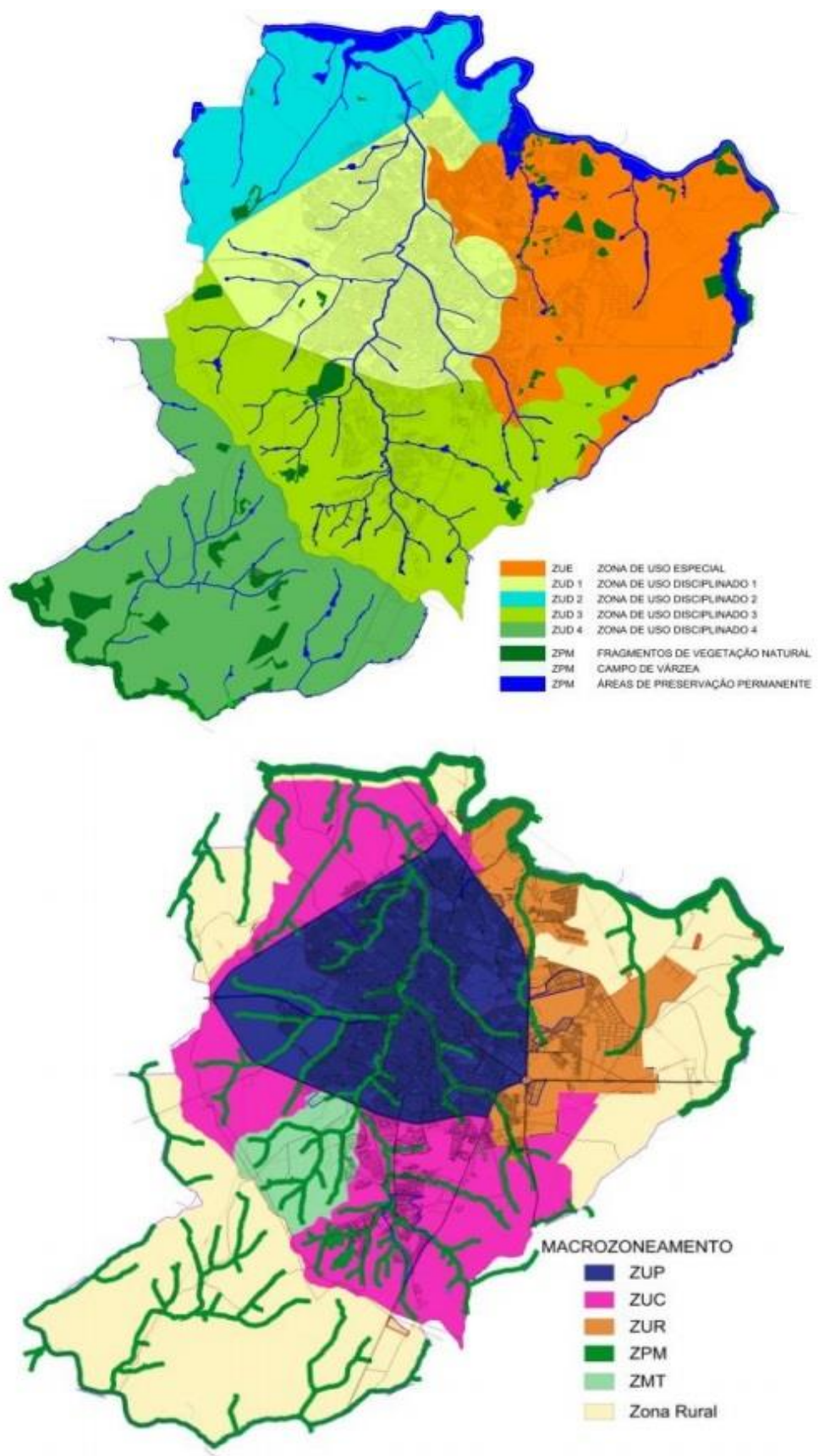

Figura 14- Mapa macrozoneamento de Ribeirão Preto (2012). Fonte: RIBEIRÃO PRETO, Justificativa Técnica Novo Plano Diretor, 2014. 
Comparando os mapas de 2007 e 2012 é possível notar um considerável aumento do perímetro da zona de expansão urbana, principalmente nas regiões Sul e Noroeste. A região em rosa (ZUC - Zona de Urbanização Controlada) no canto superior esquerdo é uma região majoritariamente industrial, conectada pelo anel viário e pela via anhanguera. A região rosa meridional é o mencionado "vetor sul" do desenvolvimento imobiliário.

Entretanto, tais disposições perderam vigência em fevereiro de 2015 quando o Decreto Legislativo 75/2015 do TJ-SP suspende a execução da Lei Complementar n 2.505/2012, tendo em vista a procedência da Ação Direta de Inconstitucionalidade no 2098360-48.2014.8.26.0000. de autoria da Procuradoria Geral de Justiça do Estado de São Paulo. Sendo assim, a LC No 2157/2007 voltou a estar em vigor (efeito repristinatório)

Os autores alegaram que a lei impugnada não contou com a participação comunitária no processo legislativo e, por esta razão, violou o artigo 180, II e 191 da Constituição do Estado de São Paulo que exige que a disciplina do parcelamento do solo urbano e de matéria referente a urbanização em sua elaboração e modificação, seja precedida de estudos técnicos e de oitiva da comunidade, de maneira a impedir revisões pontuais que molestem o desenvolvimento sustentável, Ainda, argumentou-se que a Constituição Federal prevê em seu artigo 30, VIII a competência dos Municípios para promover o adequado ordenamento territorial e no artigo 29, XII, preconiza a cooperação das associações representativas, o que assegura a participação da população em todas as matérias atinentes ao desenvolvimento urbano e ao meio ambiente. Sendo assim tal participação se daria em todas as fases do processo legislativo até o final e, na ausência da participação da comunidade, violados estão os artigos referidos.

De acordo com o parecer e o voto do Desembargador José Carlos Gonçalves Xavier de Aquino, relator do caso, a proposta de alterações na organização territorial de Ribeirão Preto carecia de estudos técnicos as que embasassem, afrontando, de fato os artigos 180, II, e 191 da Constituição do Estado e, por força do artigo 144 da mesma, feriu também o artigo 182, caput, da Constituição Federal. São techos do voto:

\section{VOTO No 27.021}

Em projeto legislativo de tamanho vulto, olvidou-se a Câmara Municipal em empreender estudos tendentes a assegurar que a lei complementar atingisse a finalidade precípua de, organizando o território do munícipio de forma técnica e ordenada, propiciar o bem-estar dos munícipes, através do desenvolvimento das funções sociais da cidade. E ao assim proceder, afrontou o artigo 182, caput, da Constituição Federal que dispõe que "A política de desenvolvimento urbano, executada pelo poder público municipal, conforme diretrizes gerais fixadas em lei, tem por objetivo ordenar o pleno desenvolvimento das funções sociais da cidade e garantir o bem-estar de seus habitantes

(...) Para que a norma urbanística tenha legitimidade e validade, ela deve decorrer de um planejamento, isto é, um processo técnico instrumentalizado para transformar a realidade existente de acordo com os objetivos previamente estabelecidos. Não pode decorrer das simples vontade do administrador, mas de 
estudos técnicos que visem assegurar o pleno desenvolvimento das funções sociais da cidade (habitar, trabalhar, circular e recrear) e garantir o bem-estar de seus habitantes. Previsto e exigido pela Constituição arts. 48, IV, 182, da CF e art. 180, II, da CE), tornou-se imposição jurídica a obrigação de elaborar planos e estudos quando se tratar de elaboração normativa relativa ao estabelecimento de diretrizes e normas relativas ao desenvolvimento urbano. (...) P. 12

(...) Assim, na esteira de precedentes jurisprudenciais e do bem lançado parecer ministerial - a norma vergastada por esta via, padece de inconstitucionalidade, não observando a exigência constitucional de participação popular, bem como da necessidade de estudo prévio do uso e ocupação do solo no município e, assim, fere de morte os artigos 180, II, e 191 da Constituição do Estado e, por força do artigo 144 da citada Carta, fere também o princípio contido no artigo 182, caput, da Constituição Federal (BRASIL, 2015, p.13)

O julgamento evidencia a arbitrariedade da administração pública no que diz respeito à participação popular na construção das leis urbanísticas. Em períodos de revisão do plano diretor, ou de discussão de leis na área, não são raras as vezes em que a prefeitura marca as reuniões em horários comerciais, contando com a baixa adesão da população mais vulnerável. O COMUR, por exemplo, é um espaço interessante para que essa troca aconteça. O Conselho foi criado e regulamentado em 98 justamente para que houvesse difusão do conhecimento técnico sobre organização urbana, bem como para dar voz ao cidadão na nova fase democrática em que país se inseria. Entretanto, a maioria das associações de bairros que participam oficialmente das assembleias é composta por membros de classe media e alta. Por exemplo: AAVIGO - Associação Amigos da Vila do Golfe (região de condomínios fechados), AASG - Associação Amigos do Saint Gerard (loteamento fechado), SACY - Sociedade Amigos City Ribeirão, SAC - Sociedade amigos do Canadá, ASAC - Associação Amigos do Jardim Canadá, AMOR - Associação dos Moradores da Ribeirânia, NOVASUL - Associação dos Amigos do Nova Aliança Sul (loteamento fechado), AMASUL - Associação Amigos do Nova Aliança Sul. Sem contar os representantes da ACI-RP - Associação Comercial e Industrial de Ribeirão Preto, CDLCâmara de Dirigentes Lojistas de Ribeirão Preto. Inclusive, a presidência do Conselho já esteve sob comando de representantes com altos cargos na indústria da construção civil local. Sendo assim, por mais que o COMUR desempenhe um trabalho bastante competente sem suas análises, parece faltar representatividade em seus conselhos.

\section{O novo vetor de crescimento e os Vazios Urbanos}




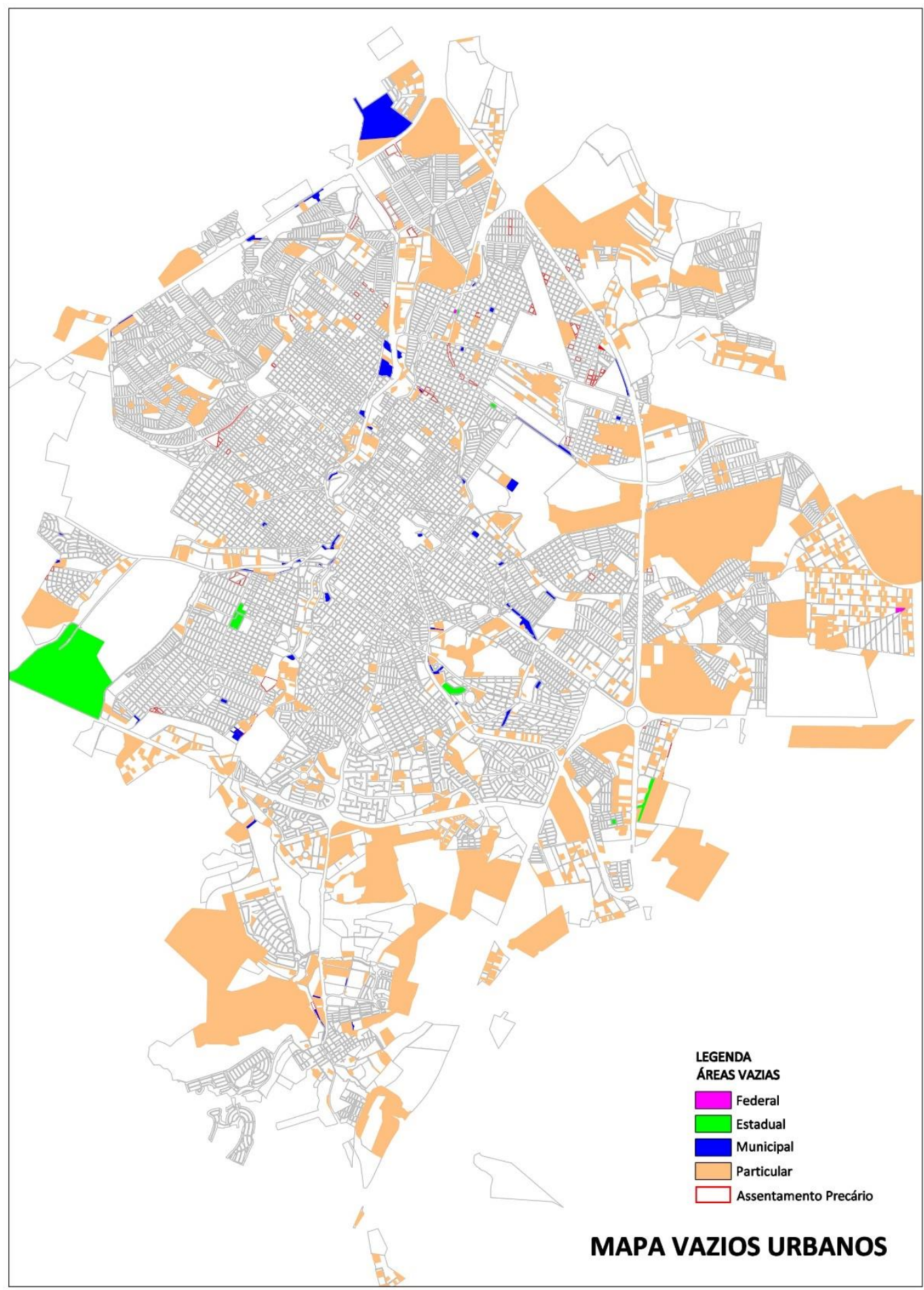

Figura 15 - Mapa de Vazios Urbanos em Ribeirão Preto; Autor: Rodrigo Rissi Geraldi, Ribeirão Preto, 2016. No art. $6^{\circ}$ da LC 501 de 1995 (plano diretor) determina-se que a política de produção e organização do espaço físico municipal será orientada pelos seguintes objetivos:

I - aumentar a eficiência dos serviços públicos municipais, reduzindo os custos de urbanização, otimizando os investimentos públicos realizados e estimulando os empreendimentos imobiliários nas áreas onde a infra-estrutura básica esteja subutilizada; 
II - estimular a ocupação dos vazios urbanos; III - promover a recuperação de áreas públicas, liberando o solo para uso coletivo e paisagístico e propiciando a melhoria das condições do ambiente construído; (grifo nosso)

No mapa feito com dados coletados em 2016 e 2017 percebe-se que muito embora a política urbana determine a ocupação de lotes não ocupados são inúmeros os espaços vazios dentro perímetro urbano e da zona de expansão urbana. Destacam-se as propriedades particulares nas regiões Sul e Sudeste do município, as regiões de maior valorização imobiliária. É curioso observar, também, a diferença de tamanho entre os vazios, sendo verdadeiros latifúndios urbanos nas regiões sul e sudeste, e pequenos na maior parte do interior do anel viário. Levando em consideração que o setor meridional do município concentra o maior número de condomínios alto padrão, é possível especular que o exagerado tamanho das propriedades sem uso seja com o intuito de resguardar o território rural de baixo valor para futuros empreendimentos do tipo, quando oportunamente valorizados pelo crescimento da cidade. Esse é mais um indício de que a definição das zonas rurais e urbanas não segue um critério embasado na legislação local visto que desrespeita o art. $6^{\circ}$, III do plano diretor. Ainda, não se questiona se há de fato a necessidade de expandir a malha urbana pelo território, criando "tentáculos" de cidade pela zona rural, permeados por vazios. É o que argumenta Tânia Figueira:

"Como quase todas as cidades brasileiras de médio porte, Ribeirão Preto apresentou padrões de urbanização dispersa desde os anos 1970, com a segregação clara entre zona norte - constituída em grande parte por conjuntos habitacionais promovidos pelo $\mathrm{BNH}$ - e sul, configurada para as camadas de mais alta renda. Em ambos os casos o desenvolvimento da malha urbana foi tentacular, propiciando a formação de inúmeros vazios. Nos anos 1980 o desenvolvimento imobiliário voltado às camadas de mais alta renda aconteceu por meio da verticalização do centro da cidade, em um processo que envolveu a demolição de vários casarões antigos do 124 período áureo do café [final do século XIX e início do XX] ." FIGUEIRA, 2013, p.126

Destacam-se, também, os grandes vazios urbanos particulares na região leste do mapa, além da via anhanguera, localizadas numa região que é alvo de grandes disputas imobiliárias (justamente pela consolidada infraestrutura viária.) Entretanto, essas propriedades encontram-se em área de vulnerabilidade ambiental, por serem zona de recarga do aquífero Guarani ${ }^{42}$, que abastece a cidade e boa parte da população do cone sul do continente. A zona leste de Ribeirão é considerada área de recarga por ter um solo poroso, que permite que a água infiltre mais facilmente até chegar ao aquífero. Segundo

42 Obs. Aquífero que abrange partes dos territórios do Uruguai, Argentina, Paraguai e, principalmente, Brasil, ocupando $1200000 \mathrm{~km}^{2}$ 
notícia veiculada pela mídia local, estudos encomendados pelo poder público local apontaram que o nível do aquífero havia baixado 70 metros na cidade em 80 anos. $^{43}$

Com base nisso, em 30 de setembro de $2015^{44}$, a juíza Lucilene Canella Mello, da $2^{\mathrm{a}}$ Vara da Fazenda Pública de Ribeirão Preto, determina que o local deveria ficar totalmente protegido, restringindo intervenções que pudessem impermeabilizar o solo, como imóveis ou ruas asfaltadas. A liminar visava a paralisar a expansão urbana numa área de cerca de 65 quilômetros quadrados na zona leste da cidade (equivale a cerca de $10 \%$ do total do município). A indústria de construção civil da cidade não ficou satisfeita com a decisão e investiu na judicialização e também no lobby com o poder legislativo e executivo. Em outubro de 2015 a liminar que "congelava" a expansão urbana sobre o aquífero foi suspensa pelo TJ-SP (Tribunal de Justiça), a pedido da prefeitura. Em dezembro de 2015 o assunto volta a ser discutido pela Câmara Municipal, no contexto do novo Plano Diretor que estava sendo elaborado para a cidade .Nessa ocasião os vereadores rejeitaram o projeto de plano justamente porque não se entrou em consenso em relação ao artigo 23 , que proíbe qualquer tipo de construção na área de recarga do Aquífero.

Segundo a vereadora Glaucia Berenice (PSDB), autora do projeto de lei que pretende proibir a implantação de novos parcelamentos urbanos na região, a restrição "atinge diretamente os interesses da construção civil que faz lobby em prol da liberação de novos empreendimentos imobiliários" ${ }^{\$ 5} \mathrm{O}$ caso evidencia, portanto, não só a captura política da administração pública pelo interesse privado como reforça a importância da política urbana de expansão, mostrando o potencial impacto ambiental de grande escala a partir da determinação do perímetro urbano e do zoneamento.

\subsubsection{A Zona de expansão Urbana e a questão Rural}

Com base no art. $2^{\circ}$ - VII do Estatuto da Cidade, a política urbana tem por objetivo ordenar o pleno desenvolvimento das funções sociais da cidade e da propriedade urbana mediante integração e complementaridade entre as atividades urbanas e rurais, "tendo em vista o desenvolvimento socioeconômico do Município e do território sob sua área de influência". Muito embora seja aclamada como "capital do Agrobusiness" Ribeirão Preto

\footnotetext{
43 http://www1.folha.uol.com.br/cotidiano/2015/10/1700504-decisao-que-protegia-area-do-aquiferoguarani-e-suspensa-em-ribeirao-preto.shtml

44 http://www1.folha.uol.com.br/cotidiano/2015/10/1693581-justica-barra-urbanizacao-em-ribeirao-pretosp-para-proteger-aquifero.shtml

${ }^{45}$ https://www.acidadeon.com/ribeiraopreto/politica/NOT,2,2,1172940,Audiencia+publica+discute+proteca o+do+Aquifero+Guarani+em+Ribeirao+Preto.aspx
} 
não conta com um projeto rural estruturado conjuntamente com a política urbana, o que pode comprometer eventuais intenções de planejamento. Eis alguns dados:

Tabela 6 - Estratificação das propriedades rurais em Ribeirão Preto (por área)

\begin{tabular}{|l|l|l|l|l|}
\hline \multirow{2}{*}{ Estratificação das Propriedades } & \multicolumn{2}{|c|}{ PROPRIEDADES } & \multicolumn{2}{|c|}{ ÁREA } \\
\cline { 2 - 6 } & $\mathrm{N}^{\mathbf{2}}$ & $\%$ & Há & $\%$ \\
\hline \multirow{2}{*}{ ATÉ 10 há } & 304 & $48,3 \%$ & $1.076,2$ & $2,2 \%$ \\
\hline $10-50$ & 164 & $26,0 \%$ & $3.723,5$ & $7,8 \%$ \\
\hline $50-100$ & 50 & $7,9 \%$ & $3.633,4$ & $7,6 \%$ \\
\hline $100-200$ & 47 & $7,5 \%$ & $6.698,7$ & $14,0 \%$ \\
\hline $200-500$ & 46 & $7,3 \%$ & $14.994,6$ & $31,3 \%$ \\
\hline $500-1000$ & 15 & $2,4 \%$ & $10.945,3$ & $22,8 \%$ \\
\hline$>1000$ & 4 & $0,6 \%$ & $6.829,1$ & $14,3 \%$ \\
\hline
\end{tabular}

Fonte: LUPA - Levantamento Censitário das Unidades de Produção Agropecuária do Estado de São Paulo 95-96; CATI Escritório de Desenvolvimento Rural de Ribeirão Preto.

Pelo que se extrai da tabela 48,3\% das propriedades rurais de Ribeirão Preto (ao todo 304 unidades) configuram pequena propriedade de acordo com o módulo fiscal do município que é 10 ha, informado pelo INCRA. Entretanto, esses imóveis ocupam apenas 2,2 \% da área total das propriedades enquanto apenas 4 propriedades com mais de 1000 ha ocupam 14, 3\% do total, sendo a maioria entre 200-500 há (31,3\%). Conforme elucidado por Pires (1996) além de evidenciar uma grande concentração fundiária, que inviabiliza a construção de uma zona rural diversa e inclusiva, chama-se atenção para o potencial disruptivo que essa configuração pode ter nas políticas municipais (e, consequentemente, 
urbanas), vez que concentra poder e renda nas mãos de um grupo restrito de pessoas (como historicamente tem sido na cidade)

Tebela 7 - Proporção Área Urbana X Área Rural (1995-2000)

\begin{tabular}{|c|c|c|c|c|}
\hline \multirow{2}{*}{ Ano } & \multicolumn{2}{|c|}{ Área urbana } & \multicolumn{2}{c|}{ Área rural } \\
\hline $1995-1996$ & 17.200 ha & $26 \%$ & 47.900 há & $74 \%$ \\
\hline 2000 & 27.408 ha & $42 \%$ & 37.692 há & $58 \%$ \\
\hline TOTAIS: & 65.100 ha & $100 \%$ & 65.100 há & $100 \%$ \\
\hline
\end{tabular}

Fonte: LUPA - Levantamento Censitário das Unidades de Produção Agropecuária do Estado de São Paulo 95-96; CATI Escritório de Desenvolvimento Rural de Ribeirão Preto.

Por esse gráfico constata-se a retração territorial da zona rural em relação à urbana, analisando pelo período de 1995 até 2000. Ainda que seja esperado esse resultado, diante do constante crescimento da cidade de Ribeirão Preto, essa mudança também reflete o perfil das gestões públicas na área rural. Note-se que mesmo sendo um polo agroindustrial, sede do maior evento agrícola do país (Agrishow), o município de Ribeirão Preto não conta com escritório do INCRA e não possui uma Secretaria Municipal da Agricultura autônoma, sendo que as atividades envolvendo o tema são trabalhadas internamente à Secretaria Municipal de Meio Ambiente. Pelo que se percebe, todo o planejamento e suporte técnico à Zona Rural de Ribeirão Preto é feito pelo CATI (Escritório de Desenvolvimento Rural de Ribeirão Preto), entidade estadual vinculada á Secretaria de Agricultura e Abastecimento, o que limita a atuação na área vez que a instituição se dedica a atividades em escala regional-estadual. Além disso, a organização territorial da zona rural é competência do Município, o que impede uma atuação mais contundente do CATI pois sempre dependerá do aval ou da solicitação da administração pública local.

Por mais que a população rural em Ribeirão Preto seja consideravelmente menor que urbana e suas atividades estejam cada vez menos ligadas ao campo, ainda existem elementos que obrigam a administração pública local a se dedicar à questão (pelo menos mais do que vem se dedicando). De acordo com o CATI (2015), aproximadamente $30 \%$ das hortaliças que abastecem os mercados da cidade são produzidas no próprio município. Vale destacar a produção do assentamento Mário Lago, um conjunto de aproximadamente 
264 famílias, sob liderança do MST, cujo principal objetivo da coordenadoria regional é recuperar a área degradada pela ação do agronegócio implantando um sistema de agroecologia, pretendendo construir um cinturão verde e garantir o fornecimento de produtos orgânicos para a cidade (FERRANTE, 2010). Talvez o assentamento seja uma das poucas entidades a se dedicar à política "rururbana" definida pelo plano diretor, que determina tanto a participação popular nas decisões sobre a zona rural quanto prevê a instalação de cinturão verde para garantia de segurança alimentar (RIBEIRÃO PRETO, 1995):

ARTIGO $3^{\circ}$ - São objetivos da política de desenvolvimento municipal: IV - a participação dos cidadãos no processo de uso, disputa e administração do desenvolvimento urbano e rural, mediando os conflitos de interesses; ARTIGO $7^{\circ}$ - Constituem diretrizes gerais da produção e organização do espaço físico: II - estabelecer as relações entre a área urbanizada e a área rural, de forma a implantar Um modelo urbanístico flexível e adaptativo ao processo de desenvolvimento econômico, social e ambiental do município; VI - a articulação dos agentes públicos e privados envolvidos no processo de uso, disputa e administração do desenvolvimento urbano e rural, mediando os conflitos de interesses;

ARTIGO 10 - Constituem diretrizes específicas da organização físico-territorial do município: IV - o estímulo ao uso agrícola ao longo do parque linear localizado às margens do Córrego Laureano e Dos Campos, constituindo um cinturão verde para o abastecimento da cidade, sendo estas áreas isentas da aplicação do Imposto Predial e Territorial Urbano progressivo;

ARTIGO 158 - Na execução e implementação das diretrizes gerais estabelecidas neste Plano Diretor, o Poder Executivo observará: VIII - com que a zona rural do território do município, seja considerada, nos seus aspectos físicos, econômicos e sociais, como tais integrados na Política Municipal de Desenvolvimento, por imperativo do disposto no artigo 155 da Lei Orgânica do Município de Ribeirão Preto;

Figura 16 - Pequenas Áreas Agrícolas X Grandes Empreendimentos Imobiliários 


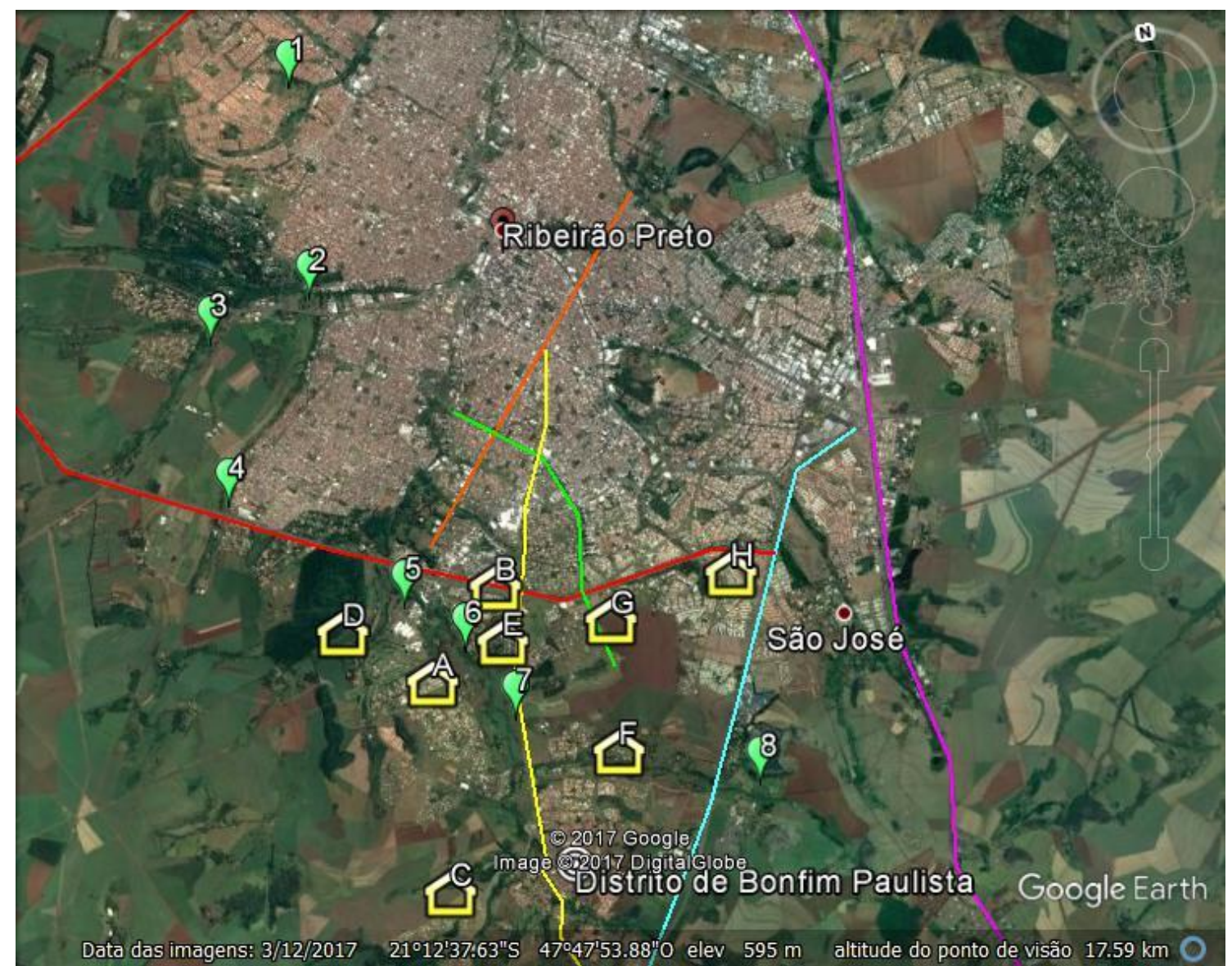

Fonte: Google Earth; CATI Escritório de Desenvolvimento Rural de Ribeirão Preto, 2017. Elaborado pelo autor.

$\mathrm{Na}$ imagem estão pontuados alguns dos remanescentes pontos de produção agrícola em pequenas propriedades, geralmente de hortifrúti. Dentre eles a região do Planalto Verde (1); a região do córrego Laureano, na avenida bandeirantes (2), a região do Jardim Itaú, à beira da rodovia Mário Donegá (3); no encontro da avenida patriarca com o anel viário (4); a atual região da Vila do Golfe, em frente ao Shopping Iguatemi $(5 ; 6)$, Região de Bonfim Paulista (7;8). Todas elas estão dentro da zona urbana ou em zona de expansão urbana, sendo que grande parte dessas regiões agrícolas existe desde o início do século XX, quando a crise de 1929 permitiu que as terras cafeicultoras fossem acessadas por parte mais ampla da população (PIRES, 1996). Os itens em amarelo identificam algumas das principais aglomerações de condomínios e loteamentos fechados na zona sul. Dentre eles Royal Park (A), Nova Aliança Sul (B), Alphaville (C), complexo do Golf (D), Quinta da Boa Vista (E). Analisemos a região do Golf-Shopping Iguatemi:

Figura 17 - Pequenas Propriedades Rurais no epicentro da Especulação Imobiliária - Zona Sul de Ribeirão Preto (Vila do Golfe) 


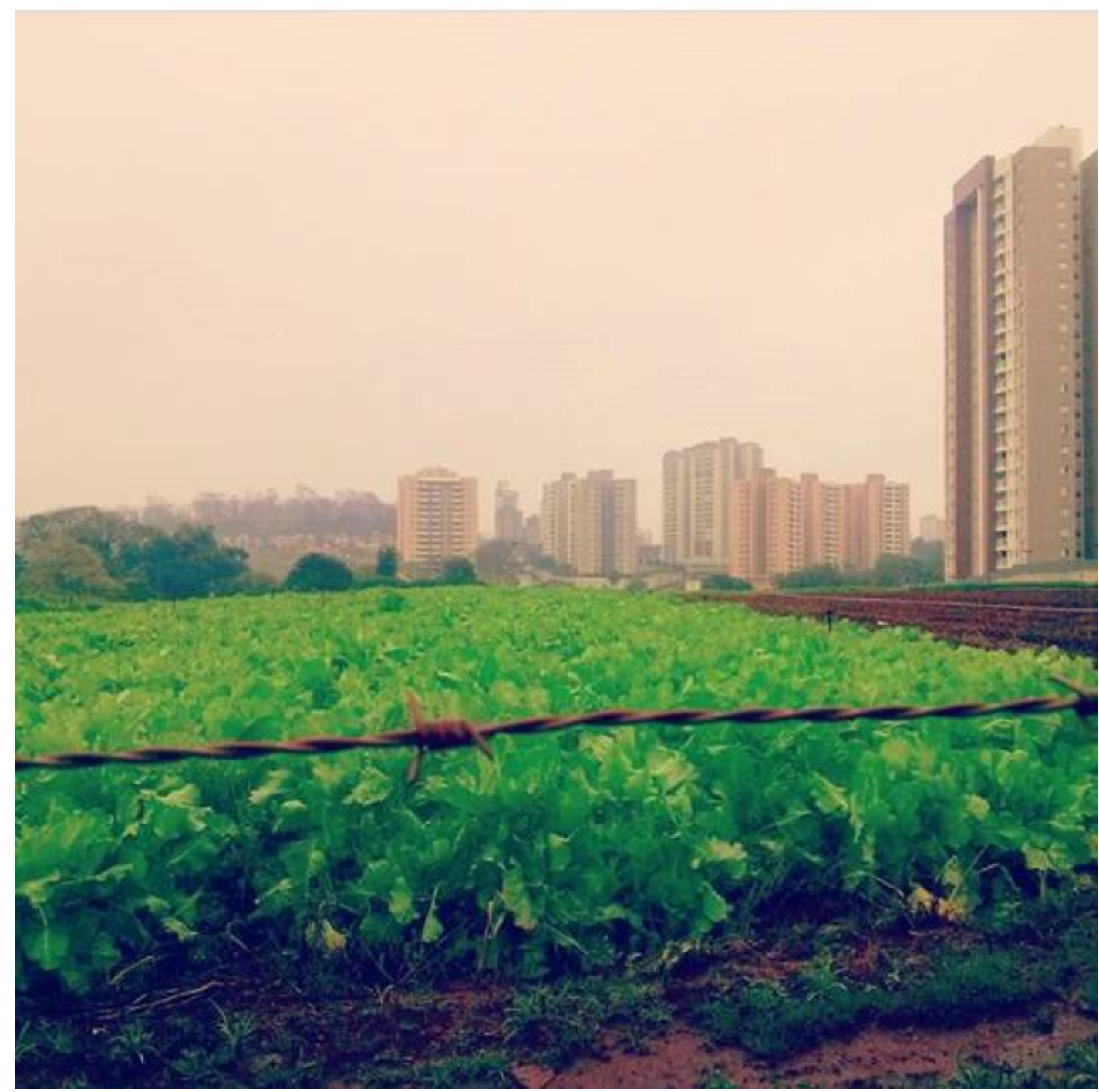

Fonte: Foto produzida pelo autor, dez. 2015.

A foto é bastante simbólica sobre o processo de expansão urbana de Ribeirão Preto em relação à zona rural. Os pequenos agricultores dificilmente têm voz ativa no planejamento do território, seja por falta de instrução ou oportunidade, e não são contemplados por políticas públicas que permitam interagir em pé de igualdade com o urbano. É comum encontrar pequenas propriedades agrícolas na zona sul dividindo o mesmo muro com grandes complexos de condomínios (o que gera inconvenientes para ambos os lados). A seguir é possível ver com mais detalhes a evolução da expansão urbana sobre a região hortifruti demonstrada na figura 16 No canto superior direito está o entroncamento viário que conecta a rodovia SP-322 (Prefeito Antônio Duarte Nogueira) à avenida Ângelo Gennaro Gallo. Próximo ao acesso viário está o Loteamento Nova Aliança Sul (parte dele fechado); ao centro da foto está o conjunto de propriedades agrícolas de hortifrúti; à esquerda se encontra a Estação Ecológica Estadual da Mata de Santa Tereza, 
com cerca de 180 hectares de Mata Atlântica e, por fim, na parte inferior da região está o local de construção do Shopping Iguatemi:

Figura 18 - Região do Shopping Iguatemi (2004)

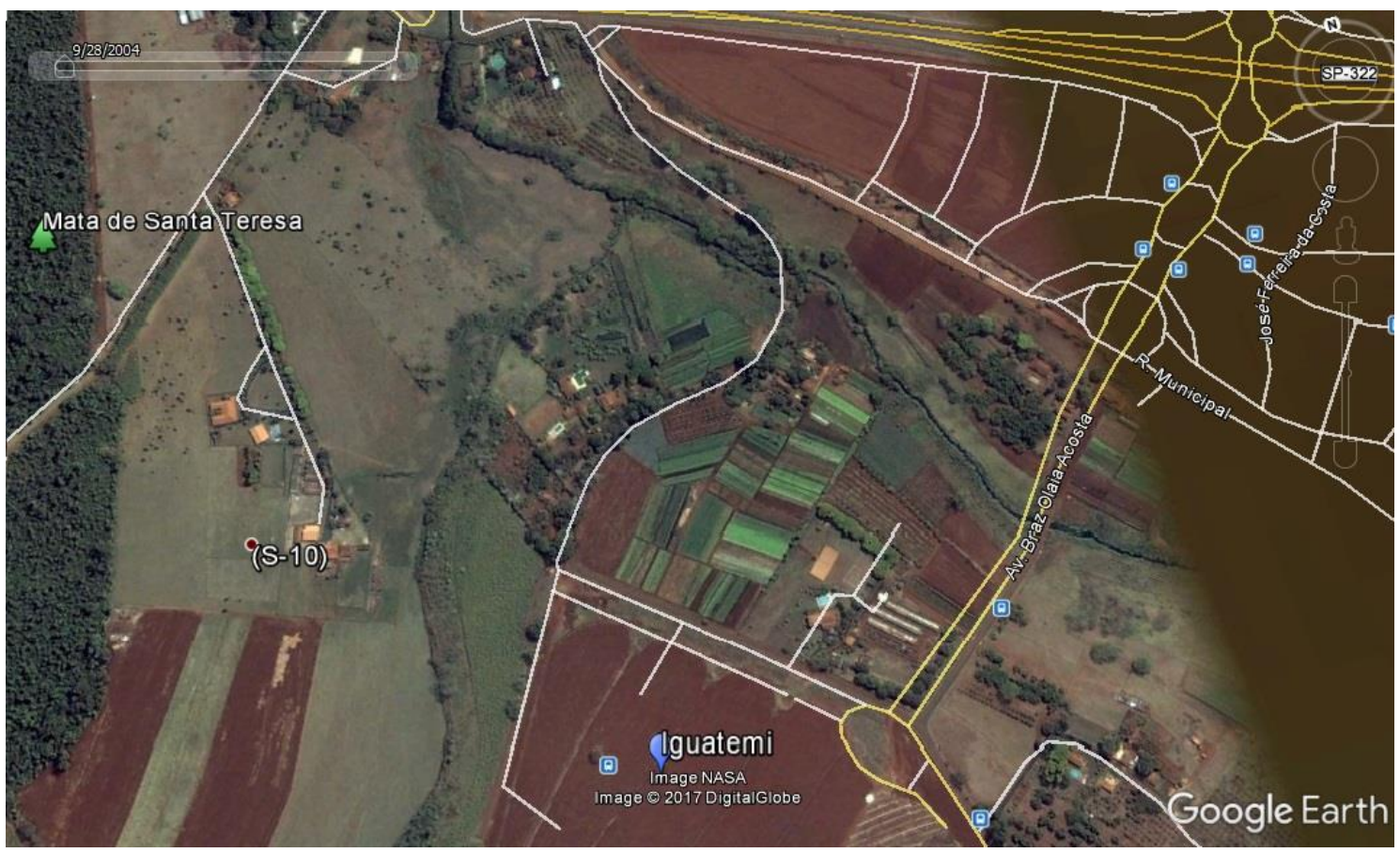

Fonte: Google Earth, 2004-2017. Elaborada pelo autor.

Figura 19- Região do Shopping Iguatemi (2012). Elaborada pelo autor. 


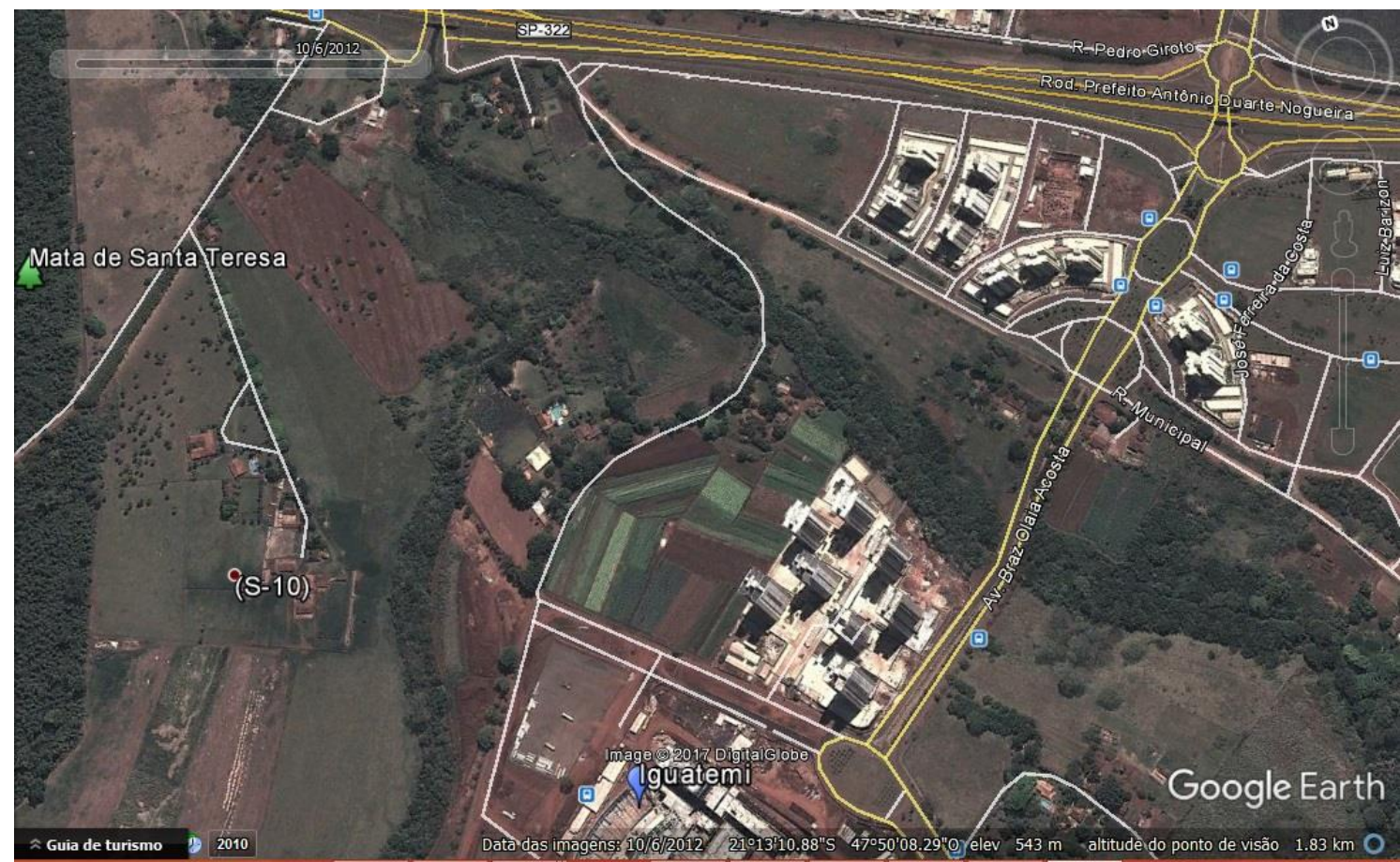

Fonte: Google Earth, 2012-2017. Elaborada pelo autor.

Figura 20 - Região do Shopping Iguatemi (2017)

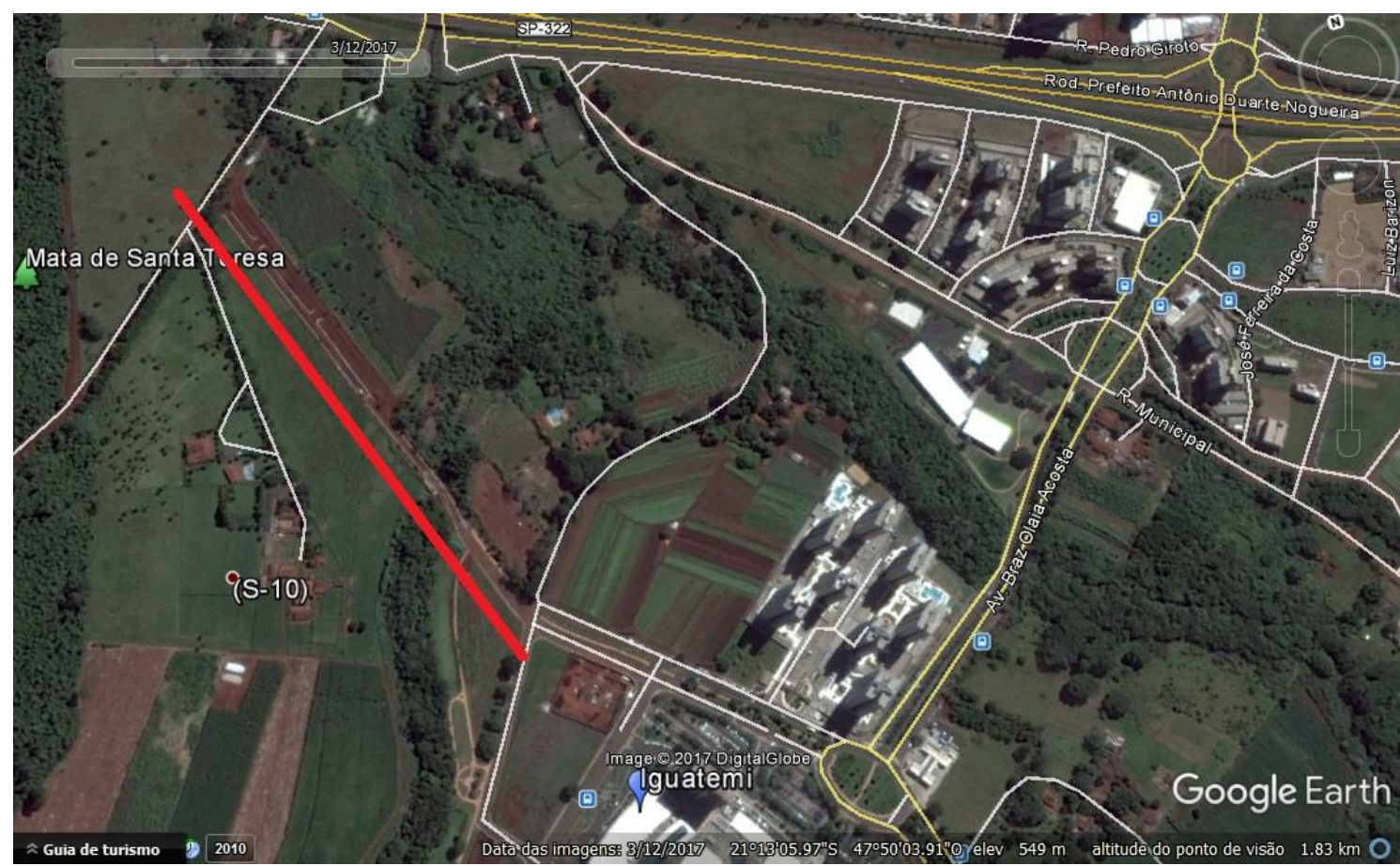

Fonte: Google Earth, 2017.

As figuras permitem observar o avanço dos empreendimentos imobiliários para além o anel viário, na região Sul de Ribeirão Preto, região que tradicionalmente abriga pequenas propriedades agrícolas (PIRES, 1996). Na última foto, de 2017, têm-se a produção de hortifrúti lado a lado com o condomínio de edifícios "Reserva do Golf Resort" e, do outro 
lado da avenida Luiz Eduardo Toledo Prato, está o Shopping Iguatemi já construído (inaugurado em 2013). A linha em vermelho sinaliza a construção de mais um acesso à região, dando espaço para mais uma conexão pelo anel viário. É notável a semelhança com o processo de valorização iniciada pelo Ribeirão Shopping nas décadas de 1980 e 90, envolvendo centro comercial de alto padrão, sistema viário e apartamentos em condomínios. São figuras bastante simbólicas do movimento de expansão territorial capitalista descrito por David Harvey (2005), em que a infraestrutura viária abre caminho para novas centralidades de consumo viabilizando a continuidade do processo de acumulação. As novas vias são exclusivamente para carros e incentivam o consumo de automóveis, o que é reforçado por uma política pública precária em mobilidade urbana. $\mathrm{O}$ Shopping é o centro de toda as atividades de lazer, de convivência, de serviços e comércio na região, inclusive abriga um escritório da Polícia Federal onde se faz o cadastro e retirada de passaportes. Por fim, os condomínios fechados, murados e ajardinados, criam um verdadeiro mosaico de enclaves e exclusividades na paisagem urbana, diferenciados entre si por uma escala de valor e comodidades.

Como se percebe, o novo modal de desenvolvimento urbano condiciona desde a mobilidade, a moradia, a interação social, o lazer e até os serviços públicos a um comportamento de consumo, calcado na utilização de espaços privados em detrimento do espaço público. Nesse contexto, a zona rural parece ter 2 únicas opções - ou desenvolve atividade de agroindústria baseada no latifúndio ou serve como reserva de valor para a expansão imobiliária, tendo a oscilação dos preços agrícolas como único critério para embasar a transformação de um em outro (BONDUKI, 2009). Ainda, conforme demonstrado por Garrefa (2004), há uma íntima relação entre os grandes proprietários de terra e a criação de bairros exclusivos. Sendo assim, diante de todos os elementos abordados, parece inevitável chegar à conclusão de que o aumento desproporcional na área de expansão urbana sobre o campo, na região sul de Ribeirão Preto, atende a interesses eminentemente financeiros e comerciais, com conivência da administração pública, ignorando as diretrizes urbanísticas da lei, a despeito do interesse coletivo. 


\section{CONSIDERAÇÕES FINAIS}

Diante de todo o exposto, é importante fazer menção preliminar às dificuldades metodológicas enfrentadas durante o caminhar da pesquisa. Por mais que se quisesse dar um enfoque mais empírico do que doutrinário, a estratégia não foi possível em sua totalidade. A coleta de dados foi bastante prejudicada pelo curto período de tempo para levantamento, somada à dificuldade encontrada nas repartições públicas em acessar as informações desejadas.

Constatou-se que pesquisas com enfoque sociológico e metodologia empírica não comportam a limitação de prazo de 2 anos vez que muitas dinâmicas sociais e econômicas analisadas se dão de maneira imprevisível e, portanto, não dependem só do pesquisador para serem estudadas. No caso, a captura econômica de uma política urbana estatal demandava informações que muitas vezes não estavam registrados em documentos e estatísticas, existindo apenas nas conversas "de bastidores" com agentes ou testemunhas. Os problemas dessas conversas extraoficiais são justamente a dificuldade em dar validade científica para elas (não havia consentimento das gravações, por exemplo) e, também, o risco real a que o pesquisador é exposto. Vale lembrar que em 2016 a prefeita de Ribeirão Preto, o presidente da câmara dos vereadores, secretários e outros agentes públicos foram presos em função de investigações da polícia federal em esquemas corrupção, inclusive envolvendo construtoras (vide operação Sevandija). Esse episódio parou a cidade por meses, já que a boa parte da linha sucessória à posse do cargo estava presa ou inabilitada para o exercício da função, criando inseguranças e animosidades em todos os setores públicos municipais.

Entretanto, alguns percalços por ventura se tornaram resultados empíricos relevantes para o objetivo buscado. Por exemplo, a dificuldade em marcar reuniões e acessar informações junto da Secretaria de Planejamento Urbano se deram porque dois dos cinco dias de funcionamento da repartição pública são inteiramente ocupados por agentes de construtoras apresentando projetos, esperando aprovação (ou pressionando por isso). Por mais que não se tenha logrado em coletar todos os dados documentais desejados, foi possível constatar que o principal órgão técnico de planejamento urbano possui uma equipe bastante enxuta perto do volume de trabalho que lhes é designado. Sendo assim, a atividade de planejamento fica comprometida, fazendo com os agentes públicos dediquem grande parte do tempo a analisar projetos empresariais de loteamentos, contribuindo para a preponderância desse tipo de atividade sobre a pública. 
Obviamente esse cenário não é um mero problema de déficit de pessoal. Enxergase íntima relação com o cenário político e econômico tratado na pesquisa, em que as atividades estatais são reduzidas a meras funções regulatórias em detrimento da "eficiência gestora do mercado", que rege conforme os interesses de seus agentes, privatizando atividades tipicamente estatais e tirando da população a soberania sobre seu próprio território e destino.

À parte das dificuldades, foi de fato possível tirar algumas conclusões.

Uma das constatações mais curiosas da pesquisa foi perceber o quanto o período da febre amarela, no início do século XX, foi determinante para conformação sócioterritorial de Ribeirão Preto. Conforme demonstrado pela Tabela 1, várias leis alteraram o perímetro urbano com base em critérios fitossanitários, separando a as classes altas (ligadas à cafeicultura) dos imigrantes e lavradores mais pobres, estabelecendo hospitais e cemitérios indesejados para longe do contato da oligarquia. A segregação norte-sul que nesse período se iniciou no quadrilátero central, entre Higienópolis e baixada, se reproduziu ao longo do tempo com grande conivência da administração pública, sempre se valendo da falaciosa neutralidade técnica do perímetro urbano.

Também foi constatado que a expansão urbana não necessariamente é danosa ao campo. No início da pesquisa se tinha a impressão de o alastramento da cidade seria sempre acompanhado de sentença de morte à zona rural. Entretanto, tanto a bibliografia quanto as visitas pelas regiões da cidade mostraram que na verdade há um potencial muito grande na junção dos dois mundos. O assentamento Mário Lago do MST foi uma grata surpresa durante as pesquisas de campo, mostrando grande capacidade em conciliar proximidade do centro urbano com a produção sustentável de alimentos.

Por fim, a hipótese central dessa pesquisa era que havia uma captura econômica do poder institucional municipal na determinação do solo via perímetro urbano. A conclusão é positiva nesse sentido. A análise dos textos das leis municipais e posterior sobreposição com dados geográficos mostraram que existem grande permeabilidade às irregularidades urbanísticas quando os infratores são de renda mais elevada. E que há severo rigor ao regramento urbanístico quando os infratores são mais pobres. Pela pesquisa se contatou que os anos 80 foram um divisor de águas na configuração socioeconômica da cidade pois a elite econômica que que antes dominava o setor agrícola migrou para o setor financeiro e da construção civil. Dessa forma, o mesmo poder de influência que se tinha no período do café agora é utilizado num espectro muito maior de atuação. 


\section{REFERÊNCIAS}

ANDRADE, L. T. Estilos de vida nos condomínios residenciais fechados - Brasil. In Frúgoli Jr, H. Andrade; L. T.; Peixoto; F. A (Org.). As cidades e seus agentes: práticas e representações. Belo Horizonte, 2006. p. 305-325.

ANITUA, Gabriel Ignacio. Notas sobre la metodología de investigationes empíricas em derecho. In COURTIS, Christian. Observar la ley: ensayos sobre metodología de la investigación jurídica. Madrid: Trotta, 2006, p. 299/319.

AGAMBEN, Giorgio. Metropolis. Sopro, n.26, abr. 2010. Disponível em:<www.culturaebarbárie.ong-sopro-verbetes-metropolis.html> Acesso em: 17 fev. 2017

AKAOUI, F. R. V. Apontamentos acerca da aplicação do Código Florestal em áreas urbanas e seu reflexo no parcelamento do solo. In: FREITAS, J. C. de (coord.). Temas de Direito Urbanístico 2. São Paulo: Centro de Apoio Operacional de Urbanismo e Meio Ambiente; Ministério Público de São Paulo, 2000.

ARAGÃO, Thêmis Amorim. Housing Policy and the Restructuring of Real Estate Sector in Brazil. Artigo apresentado no seminário internacional The Real Estate and Financial Complex (REFCOM), Leuven, 2014, mimeo.

ARTHURS, Harry William. Law and Learning. Report to the Social Sciences and Humanities. Research Council of Canada by the Consultative Group on Research and Education in Law, Information Division, Social Sciences and Humanities Research Council of Canada. Ottawa, 1983.

AZEVEDO, Eurico de Andrade Azevedo, entrevista concedida a autora, São João da Boa Vista, 2010. 01 de abril. Gravação de vídeo e som.

BANCO MUNDIAL. Avaliação de Perdas e Danos: Inundações e Deslizamentos na Região Serrana do Rio de Janeiro - Janeiro de 2011. Relatório elaborado pelo Banco Mundial com apoio do Governo do Estado do Rio de Janeiro. Brasília, $2012 . \quad$ Disponível em http://mi.gov.br/pt/c/document_library/get_file?uuid=74dde46c-544a-4bc4a6e1-852d4c09be06\&groupId=10157 acessado em 07/2017

BENTES, Júlio Cláudio da Gama. São Paulo, por Raquel Rolnik. Estud. av., São Paulo , v. 25, n. 71, p. 331-336, Apr. 2011 . Available from $<$ http://www.scielo.br/scielo.php?script=sci_arttext\&pid=S0103-

40142011000100025\&lng=en\&nrm=iso>. access on 17 July 2017. http://dx.doi.org/10.1590/S0103-40142011000100025.

BEZZON, J. C. F. O Planejamento Para o Desenvolvimento Local em Cidades "Glocais" Brasileiras: em direção ao novo modus operandi de gestão e produção da cidade. 13/10/2008. 272 fls. Tese de doutorado. Escola de Engenharia de São Carlos, Universidade de São Paulo, São Carlos, 2008.

BONDUKI, Nabil.G. Origens da habitação social no Brasil: Arquitetura Moderna, Lei do Inquilinato e Difusão da Casa Própria. Estação Liberdade;FAPESP, [1998] 2004. 
; KOURY, A. P. Das Reformas de Base ao BNH: as propostas do Seminário de Habitação e Reforma Urbana. In: ENANPPUR, 12, 2007, Belém. Anais do XII ENANPPUR: UFPA, 2007, 15 p.

. (coord.)(2009).Urbanização e preços da terra nas franjas urbanas em municípios no estado de São Paulo. Relatório final de Pesquisa em Políticas Públicas entregue à Fapesp em dezembro de 2009. São Paulo, Fapesp. (orgs). Expansão urbana em questão: Instrumentos para ordenar o crescimento das cidades. São Paulo: Instituto Pólis, 2010, p.149-164.

BRASIL, Constituição. A Constituição de 1824. 1986.

. Decreto $n^{0}$ 15.803, de 11 de Novembro de 1922. Dispõe sobre instalação do patronato agrícola de Ribeirão Preto. Disponível em http://www2.camara.leg.br/legin/fed/decret/1920-1929/decreto-15803-11novembro-1922-510083-publicacaooriginal-1-pe.html. Acesso em jul. 2017

. Decreto de 13 de Novembro de 1832. Dispõe sobre. "Prescreve a maneira de se fazer effectiva a creação de uma villa". Coleção de Leis do Império do Brasil - 1832, Página 186 Vol. 1 pt. II (Publicação Original). Disponível em http://www2.camara.leg.br/legin/fed/decret_sn/1824-1899/decreto-37404-13novembro-1832-564025-publicacaooriginal-88053-pe.html . Acesso em jul. 2017

. LEI $N^{\circ} .601$, de 18 de setembro de 1850 . Dispõe sobre as terras devolutas do império. Disponível em http://www. planalto. gov. br/ccivil_03/Leis/L0601-1850. htm. Aceso em jul. 2017.

. Constituição (1891) Constituição da República dos Estados Unidos do Brasil. Rio de Janeiro, 1891. Disponível em < http://www.planalto.gov.br/ccivil_03/Constituicao/Constitui\%C3\%A7ao91.ht $\mathrm{m}>$. Acesso em 24 out. 2006. 85

. Constituição (1934) Constituição da República dos Estados Unidos do Brasil. Rio de Janeiro, 1934. Disponível em < http://www.planalto.gov.br/ccivil_03/Constituicao/Constitui\%C3\%A7ao34.ht $\mathrm{m}>$. Acesso em 24 out.2006.

. Decreto-Lei $\mathbf{n}^{\mathbf{0}} . \mathbf{5 8}$, de 15 de Dezembro de 1937. Dispõe sobre o loteamento e a venda de terrenos para pagamento em prestações. Diário Oficial da União, Rio de Janeiro, 1937. Disponível em: http://www.planalto.gov.br/ccivil/Decreto-Lei/1937-1946/Del058.htm. Acesso em 21 jun 2005.

. Decreto-Lei $\mathbf{n}^{\circ}$. 3.079, de 15 de Setembro de 1938. Regulamenta o DecretoLei $\mathrm{n}^{\circ} .58$, de 10 de Dezembro de 1937, que dispõe sobre o loteamento e a venda de terrenos para pagamento em prestações. Diário Oficial da União, Rio de Janeiro, 1938. Disponível em: http://www.jusbrasil.com.br/legislacao/116654/decreto-3079-38. Acesso em 21 jun 2005.

. Constituição (1946) Constituição dos Estados Unidos do Brasil. Rio de Janeiro, $1946 . \quad$ Disponível em http://www.planalto.gov.br/ccivil_03/Constituicao/Constitui\%C3\%A7ao46.ht m>. Acesso em 24 out. 2006 
. Lei nº 649, de 11 de Março de 1949. Autoriza o Poder Executivo a dar nova redação ao artigo 22, do Decreto-Lei $\mathrm{n}^{\circ}$ 58, de 10 de dezembro de 1937, que dispõe sôbre as escrituras de compromisso de compra e venda de imóveis loteados. Diário Oficial da União, http://www6.senado.gov.br/sicon/ReexecutaPesquisaRealizada.action?sequen cialConsulta $=2010050915371636 \&$ codigoPortal $=0$. Acesso em 2 jun, 2006.

Constituição (1967). Constituição da República Federativa do Brasil. Brasília, $1967 . \quad$ Disponível em < http://www.planalto.gov.br/ccivil_03/Constituicao/Constitui\%C3\%A7ao67.ht m>. Acesso em 24 out. 2006.

Decreto $n^{0}$. 1.486, de 7 de Novembro de 1962. Dispõe sobre o Serviço Nacional de Municípios (SENAM), criado pelo Decreto número 50.334, de 11 de Março de 1961, sua transferência para o Gabinete Civil da Presidência da república e dá outras providências. Diário http://www6.senado.gov.br/legislacao/ListaTextoIntegral.action?id=88045.

Acesso em 2 set 2005.

Lei Federal. Código Florestal Brasileiro-Lei no 4771. In: DF: Congresso Federal. $1965 . \quad$ Disponível em http://www.planalto.gov.br/ccivil_03/leis/L4771.htm. Acesso em jul. 2017

CTN. Lei ${ }^{\circ}$ 5.172, de 25 de Outubro de 1966. Dispõe sobre o Sistema Tributário Nacional e institui normas gerais de direito tributário aplicáveis a União, Estados e Municípios. Disponível em< http://www. planalto. gov. br/ccivil_03/leis L, Acesso em jul. 2017

. Decreto-Lei no ${ }^{\circ}$ 271, de 28 de Fevereiro de 1967. Dispõe sobre o loteamento urbano, responsabilidade do loteador concessão de uso e espaço aéreo e dá outras providências. Diário http://www6.senado.gov.br/sicon/PaginaDocumentos.action . Acesso em 4 jul, 2005

. Lei $\mathbf{n}^{\mathbf{0}}$. 6.766, de 19 de Dezembro de 1979. Dispõe sobre o parcelamento do solo urbano e dá outras providências. Diário Oficial da União, Brasília, 1979. Disponível em: http://www6.senado.gov.br/sicon/PaginaDocumentos.action. Acesso em maio, 2005.

. Constituição da República Federativa do Brasil de 1988. Brasília, DF. Senado Federal. $1988 . \quad$ Disponível em: <http://www.planalto.gov.br/ccivil_03/constituicao/constituicao.htm>. Acesso em: jul/2017

Código Civil. Lei no 10.406, de 10 de janeiro de 2002. Institui o Código Civil. Diário Oficial da República Federativa do Brasil, Brasília, DF, v11, 2002.

- Tribunal de Justiça do Estado de São Paulo Federal.Ação Direta de Inconstitucionalidade $\mathrm{n}^{\mathrm{o}}$ 2098360-48.2014.8.26.0000 - Brotas - Voto - lcg. Autor: Procuradoria Geral de Justiça do Estado de São Paulo. Réu: Prefeitura Municipal de Ribeirão Preto - SP. Relator: José Carlos Gonçalves Xavier de Aquino. São Paulo, 15 de outubro de 2014. Disponível em < https://jurisprudencia.s3.amazonaws.com/TJ-SP/attachments/TJ-

SP_ADI_20983604820148260000_8c3c3.pdf?Signature=LMZtwUkpSwMSx rdTvFnKWJIOtOo\%3D\&Expires=1500333970\&AWSAccessKeyId=AKIAIP M2XEMZACAXCMBA\&response-content-type=application/pdf\&X-amzmeta-md5-hash=f13ea19331a668ca086e65281b061720> acessado em 17 de julho de 2017. 
. Lei Federal no 12.608 de 2012 . Institui a Política Nacional de Proteção e Defesa Civil - PNPDEC; dispõe sobre o Sistema Nacional de Proteção e Defesa Civil-SINPDEC e o Conselho Nacional de Proteção e Defesa Civil. Disponível em http://www.planalto.gov.br/ccivil_03/_ato20112014/2012/lei/l12608.htm. Acessado em jul. 2017

. Nota Técnica $n^{\circ}$ 1/2017- PROURB/PRODEMA/PDDC. Dispõe sobre Medida Provisória $\mathrm{n}^{\circ}$ 759/2016. Disponível em http://www.mpdft.mp.br/portal/pdf/noticias/abril_2017/Nota_T\%C3\%A9cnic a_MP_759-2016_PROURB.pdf. Acesso em 08 de Jul. 2017 . Medida Provisória N. o 2.166-67, de 24 de agosto de 2001. Presidência da República disponível em http://www. planalto. gov. br/ccivil_03/MP/216667. htm> acesso em jul. 2017

CAMARGOS, Regina Coeli Moreira et al. Estado e empreiteiros no Brasil: uma análise setorial. 1993

CAMMAROSANO, Márcio. Fundamentos Constitucionais do Estatuto da Cidade. ) in: Estatuto da Cidade - Comentários à Lei Federal 10.257 de 2001. DALLARI; A.A.; FERRAZ, S. (org.). $4^{\text {a }}$ ed. São Paulo: Malheiros Editores, 2014. p. 21-26

CANO, Wilson. Raízes da concentração industrial em São Paulo. São Paulo: Difel, 1977.

CASTRO, Celso.O golpe de 1964 e a instauraçao do regime militar. FGV Online Centro de Pesquisa e Documentação de História Contemporânea do Brasil (CPDOC). Disponível em <http://cpdoc.fgv.br/producao/dossies/FatosImagens/Golpe1964>. Acessado em 04 de Julho de 2017.

CELARINO, Andre. Ribeirão Preto-SP de 2000 a 2010: Poucas mudanças. O metafísico, Ribeirão Preto, 2013. ttps://ometafisico.wordpress.com/2013/04/22/ribeirao-preto-sp-de-2000-a2010-poucas-mudancas/\#comments. Acesso em 18 de julho de 2017.

CORREA, Fábio Rogério Cassimiro. Os Bancos de Custeio Rural e o crédito agrícola em São Paulo (1906-1914). 2012. Tese de Doutorado. Universidade de São Paulo.

DEVESCOVI, Regina de Campos Balieiro. Urbanização e acumulação: um estudo sobre a cidade de São Carlos. 1985. Tese de Doutorado.

DI PIETRO. Maria Sylvia Zanella.. Direito Administrativo. São Paulo: Atlas, 2004.

DI SARNO, Daniela Campos Libório. Competências Urbanísticas (arts. $3^{\circ}$ e 51) in: Estatuto da Cidade - Comentários à Lei Federal 10.257 de 2001. DALLARI; A.A.; FERRAZ, S. (org.). $4^{\mathrm{a}}$ ed. São Paulo: Malheiros Editores, 2014. p. 63-72

DODMAN, David; SATTERTHWAITE, David. Institutional capacity, climate change adaptation and the urban poor. IDS Bulletin, v. 39, n. 4, p. 67-74, 2008.

ENGELS, Friedrich; HORA, A. Dias. Questão do alojamento. 1971.

ESTEVES, Maria Aparecida Vargas; NOGUEIRA, Marly. A proliferação e a consolidação de condomínios fechados: um estudo de caso em uma cidade médiaDivinópolis (MG). Revista Geografias, v. 9, n. 1, p. 23-39, 2013.

FARIA, V. Cinqüenta anos de urbanização no Brasil: tendências e perspectivas. Estudos CEBRAP, 29, São Paulo, 1991. p. 98-119 
FELDMAN, Sarah. Instituições de Urbanismo no Brasil na década de 1930: olhar técnico e dimensão urbano-industrial. 2007. 109 f. Tese de Livre Docência - Escola de Engenharia de São Carlos, Universidade de São Paulo, São Carlos, 2007.

ERRANE, Vera Botta. O sistema produtivo do assentamento mário lago: uma experiência de produção agroecológica no centro da indústria agrocanavieira do interior do estado de são Paulo. In Campo Grande, 25 a 28 de julho de 2009, 48 SOBER - Sociedade Brasileira de Economia, Administração e Sociologia Rural. Anais. 19 pg.

FERREIRA, Marieta de Moraes. A trajetória política de João Goulart - As reformas de base. FGV Online - Centro de Pesquisa e Documentação de História Contemporânea do Brasil (CPDOC). Disponível em $<$ http://cpdoc.fgv.br/producao/dossies/Jango/artigos/NaPresidenciaRepublica/ As_reformas_de_base.> Acessado em 04 de Julho de 2017.

. Constituição de 1988 e política urbana no Brasil: recuperando um percurso de construção de idéias e práticas. In: GOULART, J. O. As múltiplas faces da constituição cidadã. São Paulo: Cultura Acadêmica, 2009. p.63-76

FELISBINO, Riberti de Almeida. Os municípios brasileiros nas constituições federais, 1824 a 1988. 27 de março de 2012. Portal de e-governo, inclusão digital e sociedade do conhecimento. Governo de Santa Catarina. Disponível em http://www.egov.ufsc.br/portal/conteudo/os-munic\%C3\%ADpios-brasileirosnas-constitui\%C3\%A7\%C3\%B5es-federais-1824-1988 acessado em 17/06/2017 às 18:00 hrs

FIGUEIRA, Tânia Maria Bulhões. Produção social da cidade contemporânea. Análise dos Condomínios Urbanísticos e Loteamentos Fechados de Alto Padrão do Subsetor Sul de Ribeirão Preto/SP, v. 198, 2013.

FUKUYAMA, Francis. O fim da história eo último homem. Rio de Janeiro: Rocco, 1992. GARREFA, Fernando. O Ribeirão Shopping e suas quatro expansões: um retrato da evolução dos espaços e estratégias utilizadas pelos shoppings centers brasileiros. Artigo apresentado à Faculdade de Arquitetura e Urbanismo da Universidade de São Paulo. São Paulo. 2004. p.1-11. Disponível em: <http://www.usp.br/fau/depprojeto/labcom/produtos/2004_garrefa_ribeiraosh opping.pdf $>$. Acesso em jul/2017.

GRAZIANO, José Francisco da Silva. A Modernização Dolorosa. Rio de Janeiro: Zahar, 1982.

Sobre a delimitação do rural e do urbano no Brasil: Testando as Aberturas Geográficas das Novas PNADs. In: SOCIEDADE BRASILEIRA DE ECONOMIA RURAL. Anais do XXXV Congresso Brasileiro de Economia e Sociologia Rural. Brasília. 1997. p.114-146

; DEL GROSSI, Mauro Eduardo. A mudança no conceito de trabalho nas novas PNADs'. Economia e sociedade: revista do Instituto de Economia da UNICAMP., v. 8, n. 8-9, p. 247-61, 1997b.

O Novo Rural Brasileiro. Campinas, IE/UNICAMP. 1999 (2m edição

HARVEY, David. Social processes and spatial form: an analysis of the conceptual problems of urban planning. Papers in Regional Science, v. 25, n. 1, p. 47-69, 1970.

. A produção capitalista do espaço. São Paulo: Annablume, 2005

O Neoliberalismo: história e implicações. Edições Loyola: São Paulo, 2008 
HOLSTON, James. Cidadania Insurgente: disjunções da democracia e da modernidade no Brasil. São Paulo: Companhia das Letras, 2013

IBAM. A evolução do município brasileiro. Textos e Discussões. RJ: IBAM, 2000.

INSTITUTO BRASILEIRO DE GEOGRAFIA E ESTATÍSTICA. Censos Demográficos. Rio de Janeiro. IBGE. 1920, 1930, 1940, 1950, 1960, 1970, 1980, 1991, 2000 e 2010.

INSTITUTO BRASILEIRO DE GEOGRAFIA E ESTATÍSTICA. Histórico da Cidade de Ribeirão Preto-SP. Disponível em: <http://www.ibge.gov.br/cidadesat/topwindow.htm?1>. Acesso em: jul/2017.

LEAL, Victor N. Coronelismo, enxada e voto: o município e o regime representativo no Brasil. SP: Editora Nova Fronteira, 1997.

LEE-SMITH, Diana. Cities feeding people: an update on urban agriculture in equatorial Africa. Environment and Urbanization, v. 22, n. 2, p. 483-499, 2010.

LEFEBVRE, Henri. Reflections on the politics of space. Antipode, 8, p.30-37, 1976 ; SOJA, Edward. Geografias pós-modernas - a reafirmaçãodo espaço na teoria social crítica. Rio de Janeiro: Zahar, 1993

LEONELLI, Gisela Cunha Viana.A construção da lei federal de parcelamento do solo urbano 6.766: debates e propostas do início do sec XX a 1979. 2010. Tese (Doutorado em Arquitetura e Urbanismo) Escola de Engenharia de São Carlos, Universidade de São Paulo, São Carlos, 2010.

MARINHO, J.M.; A Expansão Urbana Privatizada: a lei e o mercado imobiliário no caso de Indaiatuba - SP.in: Sessão temática 3: produção e gestão do espaço urbano, metropolitano e regional. Anais: XVII ENAMPUR, São Paulo, 2017. $14 \mathrm{pg}$.

LEVY, M.; SANTORO, P.; CYMBALISTA, R. Estatuto da Cidade: uma leitura sob a perspectiva da recuperação da valorização da terra. In: SANTORO, Paula (org.). Gestão social da valorização da terra (Cadernos Pólis, 9). São Paulo: Instituto Pólis, 2004, p.14-37.

MAIA, Doralice Sátyro. Normativas urbanas no brasil imperial: a cidade e a vida urbana na legislação brasileira (1822 - 1850). Revista Geo UERJ. Rio de Janeiro - Ano $16, \mathrm{n}^{\circ} .25$, v.2, $2^{\circ}$ semestre de 2014, pp.458-476 ISSN: 1415-7543 E-ISSN: $1981-9021$

MACARINI, J.P.A política econômica da ditadura militar no limiar do "milagre" brasileiro: 1967/69. Texto para Discussão. IE/UNICAMP n. 99, set. 2000.

MACHADO, P.A.L. Direito Ambiental Brasileiro", Malheiros Editores, $4^{\mathrm{a}}$ edição, p. 252.

MARICATO, H. Brasil, cidades: alternativas para a crise urbana. Petrópolis: Vozes, 2001. 204 p. ISBN 85-326-2633-5.

MARRARA, Thiago. "Bens públicos Domínio urbano Infra-estruturas." Editora Forum, 2007.

MARX, Murillo. Cidade no Brasil, terra de quem?. São Paulo: EDUSP/Nobel, 1991.

MARX, Karl. Grundrisse, trans. Martin Nicolaus. Vintage, New York, 1973

MARX, K.; ENGELS, F. Feuerbach. Oposición entre las concepciones materialista e idealista (Capítulo 1 de La ideologia alemana).in. Escritos sobre Materialismo Histórico. Tradução de César Ruiz Sanjuán. Alianza Editorial: Madrid, 2012.

MCGRANAHAN, G.; SATTERTHWAITE, D.; TACOLI, C. "Urbanization and its implications for food and farming”. International Institute for Environment 
and Development, London . Pholosofical Transactions of The Royal Society. Phil. Trans. R. Soc. B (2010) 365, 2809-2820 doi:10.1098/rstb.2010.0136. Downloaded from http://rstb.royalsocietypublishing.org/, disponível em http://rstb.royalsocietypublishing.org/content/royptb/365/1554/2809.full.pdf. Accessed on July 10, 2017

MEIRELLES, Hely. Lopes. Limitações Urbanísticas ao uso da Propriedade. Revista dos Tribunais. São Paulo, ano 48, v. 281, p. 7-35, 1959.

Direito municipal brasileiro. SP: Editora Malheiros, 1993.

Direito de Construir, Malheiros Editores, 6 edição, 1994, p. 102.

. Direito Municipal Brasileiro. 36a edição. São Paulo: Editora Malheiros, 2010.

MINAYO, M. C. de S. (Org.). Pesquisa social: teoria método e criatividade. $17^{\mathrm{a}} \mathrm{ed}$. Petrópolis, RJ: Vozes, 1994. $80 \mathrm{p}$

MODESTO, H. Ausência de Planejamento no Brasil. Revista Notícias Municipais, Rio de Janeiro, ano VI, n. 37, p.3-16, nov-dez 1959.

MOREIRA, Mariana. A história do Estatuto da Cidade. Estatuto da Cidade: comentários a Lei federal, v. 10, 2001.

OLIVEIRA, Fabiana Luci (org.) O sistema de justiça brasileiro sob olhares empíricos.Justiça em foco: Es-tudos Empíricos. Rio de Janeiro: Editora FGV, 2012

PEREIRA, Caio Mário da Silva. Instituições de Direito Civil. Vol. IV. Direitos Reais.20 ed. De acordo com o Código Civil de 2002. Rev. E Atual. Por Carlos Edison do Rêgo Monteiro Filho. Rio de Janeiro: Forense, 2009.

PIRES, Maria Conceição Silvério. O processo de urbanização e a organização do espaço em uma Região Canavieira: a Região de Ribeirão Preto. 18/02/97. 251 p. Dissertação (Mestrado) - Faculdade de Arquitetura e Urbanismo da Universidade de São Paulo. São Paulo, 1996.

RIBEIRÃO PRETO.Ato 31 de 2 de março de 1935. Delimita a zona urbana da cidade de Ribeirao Preto. . Acesso em Jul. 2017 . http://www.ribeiraopreto.sp.gov.br/J321/pesquisa.xhtml?lei=29989Acesso em Jul. 2017

;Ato 33 de 5 de fevereiro de 1936. Delimita a zona urbana da cidade de Ribeirao Preto. Disponível em http://www.ribeiraopreto.sp.gov.br/J321/pesquisa.xhtml?lei=30011Delimita Acesso em jul. 2017

Ato 18 cd 18 de Julho de 1938. Dispões sobre Licenças", estabelecido pelo art. $50 \mathrm{n}^{\circ}$ 1, da Lei Organica dos Municipios, e demais taxas e contribuições, Disponível em http://www.ribeiraopreto.sp.gov.br/J321/pesquisa.xhtml;jsessionid=0d92388c 7266727f6e3cca2f786a?leiImpressao=30498. Acesso em Jul. 2017

Ato 28 de 30 de novembro de 1938. http://www.al.sp.gov.br/repositorio/legislacao/decreto/1938/decreto-9775-

30.11.1938.htmlDelimita o perímetro urbano do distrito de paz de Vila Bonfim . Acesso em Jul. 2017

Ato 32 de 26 de dezembro de 1938. http://www.ribeiraopreto.sp.gov.br/J321/pesquisa.xhtml;jsessionid=ff67e9533 5f4fb51f35d7a55c197? leiImpressao=30724Delimita o perímetro urbano do distrito de paz de Guatapará . Acesso em Jul. 2017 
Ato 75 de 05 de Setembro de 1939. Delimita o perímetro urbano da sede do distrito de paz de Ribeirão Preto e vila bonfim.. http://www.ribeiraopreto.sp.gov.br/J321/pesquisa.xhtml;jsessionid=ff67e9533 5f4fb51f35d7a55c197?leiImpressao=30724Acesso em Jul. 2017

Lei 168 de 23 de novembro de 1950. www.ribeiraopreto.sp.gov.br/J321/pesquisa.xhtml;jsessionid=ff67e95335f4fb $51 \mathrm{f} 35 \mathrm{~d} 7 \mathrm{a} 552342197$ ?leiImpressao=3072Divide a cidade em sete zonas . Acesso em Jul. 2017

$\begin{array}{llllll}\text { Lei } & 272 & \text { de } & 24 & \text { de } & \text { novembro } 1952\end{array}$ www.ribeiraopreto.sp.gov.br/J321/pesquisa.xhtml;jsessionid=ff67e95335f4fb 51f35d7a55csds 197?leiImpressao=3072. Dispõe sôbre limpeza e conservação dos cursos de água existentes no perímetro urbâno e suburbano da cidade e distritos.

Lei 720 de $1958 \quad 27$ de junho de 1958. www.ribeiraopreto.sp.gov.br/J321/pesquisa.xhtml;jsessionid=ff67e95335f4fb 51f35d7a55c197?leiImpressao=307234234 Modifica dispositivos do código de posturas - (terrenos baldios no perimetro urbano).. Acesso em Jul. 2017

Acesso em Jul. 2017Lei 843 de 25 de outubro de 1959. www.ribeiraopreto.sp.gov.br/J321/pesquisa.xhtml;jsessionid=ff67e $95335 \mathrm{f} 4 \mathrm{fb}$ 51f35d7a55c197?leiImpressao $=3072223$ Regulariza as contruçoes feitas sem a devida aprovação da prefeitura . Acesso em Jul. 2017

Lei 927 de $1^{\circ}$ de Junho de 1960. www.ribeiraopreto.sp.gov.br/J321/pesquisa.xhtml;jsessionid=ff67e95335f4fb $51 \mathrm{f} 35 \mathrm{~d} 7 \mathrm{a} 55 \mathrm{c} 197$ ?leiImpressao $=307223423$ Dipoe sobre terrenos baldios no perímetro urbano da cidade . Acesso em Jul. 2017

Lei 1087 de 16 de outubro de 1961. www.ribeiraopreto.sp.gov.br/J321/pesquisa.xhtml;jsessionid=ff67e $95335 \mathrm{f} 4 \mathrm{fb}$ 51f35d7a55c197?leiImpressao=30729898978. Delimita o perímetro urbano do distrito sede de Ribeirão Preto . Acesso em Jul. 2017

. Lei 1.840 de 11 de outubro de 1966. Dispões sobre alterção do perímetro urbao. Disponível em https://www.jusbrasil.com.br/topicos/21592451/lei-n1840-de-11-de-outubro-de-1966-do-municipio-do-ribeirao-preto. Acesso em Jul. 2017

Lei 1110 de 20 de novembro de 1961. Modifica a primeira zona do distrito da sede de Ribeirão Preto.

www.ribeiraopreto.sp.gov.br/J321/pesquisa.xhtml;jsessionid=ff67e95335f4fb 51f35d7a55c197?leiImpressao=3072989812312 . Acesso em Jul. 2017

Lei 1510 de 4 de Dezembro de 1964. www.ribeiraopreto.sp.gov.br/J321/pesquisa.xhtml;jsessionid=ff67e95335f4fb 51f35d7a55c197?leiImpressao $=307211329$ Delimita o perímetro urbano do distrito da sede de Ribeirão Preto. .Acesso em Jul. 2017

.Decreto 068 de 1973. Cria o COMUR. Disponível em www.ribeiraopreto.sp.gov.br/J321/pesquisa.xhtml;jsessionid=ff67e93092803 95f4fb51f35d7a55c197?leiImpressao=3072989812312. Acesso em jul.

. A Lei 2916 de 1974. Dispõe sobre regulações sobre o uso do solo. Disponivelwww.ribeiraopreto.sp.gov.br/J321/pesquisa. $x$ html; jsessionid=ff67e 9309280395f4fb51f35d7a55c197? ?eiImpressao=3012398 Acesso em jul. 2017 2017 
. Lei n. 3.349, de 07 de outubro de 1977. Define Plano Diretor Estratégico de Ribeirao Preto. Disponível em www.ribeiraopreto.sp.gov.br/J321/pesquisa.xhtml;jsessionid=ff67e280395f4f b5100985c197?leiImpressao=30726. Acesso em jul. 2017

. Lei $\mathrm{n}^{\circ} 4.375$ de 05 de Agosto de 1983. Define ocupação da avenida getulo vargas. Diponivel em https://www.jusbrasil.com.br/topicos/21568418/artigo2-da-lei-n-4375-de-05-de-agosto-de-1983-do-municipio-do-ribeirao-preto.

Acesso em Jul. 2017

- Lei Complementar $n^{0}$ 501, de 31 de outubro de 1995. Dispõe sobra a instituição do Plano Diretor do município de Ribeirão Preto e dá outras providências. Disponível em: <http://www.pmrp.com.br/splan/planod/i28planod.php>. Acesso em: jul/2017. . A Lei 2916 de 1974. Dispõe sobre regulações sobre o uso do solo. Disponivel

em

Lei Complementar $\mathbf{n}^{0}$ 1.279, de 28 de dezembro de 2001. Dispõe sobre a Planta Genérica de Valores de Imóveis Urbanos do Mmunicípio, altera dispositivos do código tributário municipal, Lei $\mathrm{n}^{\circ} 2415$, de 21 de dezembro de 1970, e dá outras providências. Disponível em: <http://www.ribeiraopreto.sp.gov.br/leis/pesquisa/ver.php?id=4950pdf>. Acesso em: jul/2017.

. Lei Complementar $n^{0}$ 2.157, de 08 de Janeiro de 2007. Dispõe sobre o Parcelamento, Uso e Ocupação do Solo no Município de Ribeirão Preto. Disponível em: <http://www.ribeiraopreto.sp.gov.br/leis/pesquisa/ver.php?id=21377>. Acesso em: jul/2017.

. Lei Complementar $n^{0} \mathbf{2 . 4 6 2}$, de 13 de Julho de 2011. Dispõe sobre a Regularização de Loteamentos Fechados no Município de Ribeirão Preto e dá outras providências. Disponível em: $<$ http://www.ribeiraopreto.sp.gov.br/leis/pesquisa/ver.php?id=33625>. Acesso em: jul/2017.

Lei Complementar $\mathbf{n}^{\circ} \mathbf{2 . 5 0 5}$, de 17 de janeiro de 2012. Dispõe sobre o Parcelamento, Uso e Ocupação do solo no município de Ribeirão Preto. Disponível em: <http://www.ribeiraopreto.sp.gov.br/leis/pesquisa/ver.php?id=33955>. Acesso em: jul/2017.

.. Lei Complementar $\mathbf{n}^{0}$ 2.572, de 28 de dezembro de 2012. Dispõe sobre a Planta Genérica de Valores de Imóveis Urbanos do Mmunicípio, altera dispositivos do código tributário municipal, Lei n ${ }^{\circ} 2415$, de 21 de dezembro de 1970, e dá outras providências. Disponível em: <http://www.ribeiraopreto.sp.gov.br/dom/sdom/uploads/i73121228caderno2.p df $>$. Acesso em: jul/2017.

. RIBEIRÃO PRETO. Prefeitura Municipal de Ribeirão Preto. Secretaria de Planejamento e Gestão Pública. Justificativa técnica do plano diretor. Ribeirão Preto: Sem Editora, 2014. 169 p. Disponível em: <https://www.ribeiraopreto.sp.gov.br/splan/planod/justificativa_tecnica.pdf $>$. Acesso em: 19 jul 2017. 
REIS FILHO, Nestor Goulart. "La ciudad barroca. In. Cerrilos M.L. (org), História Urbana Iberoamericana. Madrid: Testimónio, 1990.

. Contribuição ao estudo da evolução urbana do Brasil (1500 / 1720). São Paulo: Pini, 2000.

.. Notas sobre a urbanização dispersa e novas formas de tecido urbano. São Paulo: Via das Artes, 2006.

ROCHA, R.O. Loteamentos fechados e regulamentação dos espaços urbanos in: URBA - ST2 Produção Contemporânea do Espaço e Projetos de Urbanismo, UFBA, Salvador, 2011.

ROLNIK, Raquel. A cidade e a lei: legislação, política urbana e territórios na cidade de São Paulo. Studio Nobel, 1997.

. Guerra dos lugares: a colonização da terra e da moradia na era das finanças. Boitempo, 2015.

ROYER, Luciana de Oliveira. Financeirização da política habitacional: limites e perspectivas / tese de doutorado. Luciana de Oliveira Royer - São Paulo: USP / Faculdade de Arquitetura e Urbanismo, 2009.

. Financeirização da Política Habitacional - limites e perspectivas. Annablume: São Paulo, 2013

SANTOS, Paulo. Formação de cidades no Brasil Colônia. V. Congresso Internacional de Estudos Luso-Brasileiros. Coimbra, 1968.

SANTOS, Milton. Território e sociedade. 2. Ed. São Paulo: Fundação Perseu Abramo, 2000. Entrevista com Milton Santos

SAULE Jr., Nelson. Novas perspectivas do Direito Urbanístico Brasileiro Ordenamento constitucional da política urbana. Aplicação e eficácia do Plano Diretor. Porto Alegre: Sergio Antonio Fabris Editor, 1997.

. Vias Jurídicas da Política Urbana no Brasil: Sergio Antonio Fabris Editor, Porto Alegre, 2007.

The Right to the City. Strategic Response to Social Exclusion and Spatial Segregation - The Chalenges of the Democratic Management in Brazil Instituto Pólis, Ford Foundation, São Paulo, 2009, pág 39 a 62.

SCHÜRMANN, Betina. Urbanização Colonial na América Latina: ciudad planejada versus desleixo e caos. Textos de História, vol. 7, $n^{\circ} 1-2,1999$. p. 150

SOUZA, P.H.G.F.; MEDEIROS, M. "Top Income Shares and Inequality in Brazil” in Sociologies in Dialogue. Revista da Sociedade Brasileira de Sociologia (ISSN 2447-2670) SID, Porto Alegre, v. 1, n. 1, p. 119-132, jul.-dez. 2015

SILVA, José Afonso da. Direito urbanístico brasileiro. Editora Revista dos Tribunais, 1981.

SILVA, Adriana Capretz Borges da. Imigração e Urbanização: o núcleo colonial Antônio Prado em Ribeirão Preto. 2002. Dissertação (Mestrado em Engenharia Urbana). - DECiv/UFSCar, São Carlos. 
SÃO PAULO. Resolução n. 48 de 1883. Dispõe sobre alinhamento, elegancia e regularidade dos edificios. Desponível em . Http://www.al.sp.gov.br/repositorio/legislacao/resolucao/1883/resolucao-4806.08.1883.html acesso jul. 2017

Decreto $\mathbf{n}^{0}$ 233, de 02 de março de 1894. Estabelece o Código Sanitário. Disponível http://www.al.sp.gov.br/repositorio/legislacao/decreto/1894/decreto\%20n.233 \%20de\%2002. 03.1894.htm. Acesso em 17/07/2017.

. Decreto no 708, de 18/09/1899. Dá regulamento para instalação domiciliar de esgotos. Disponível em http://www.al.sp.gov.br/repositorio/legislacao/decreto/1899/decreto-70818.09.1899.html. Acesso em jul. 2017

.Lei estadual n. 865, de 17 de dezembro de 1902. Dispõe sobre os Estabelecimentos de Credito Agricola no Estado. Disponpivel em http://al.sp.gov.br/norma/?id=64957. Acesso em jul. 2017

.Decreto $\mathbf{n}^{\mathbf{0}} \mathbf{1 . 2 5 4}$, de 03/12/1904. Dá regulamento para a cobrança da taxa de esgotos na cidade de santos. Disponivel em http://www.al.sp.gov.br/repositorio/legislacao/decreto/1899/decreto-70818.09.1899.html. Acesso em jul. 2017

.Decreto $\mathrm{n}^{\circ} \mathbf{1 . 3 4 6}$, de 08/02/1906. Declara de necessidade pública, para serem desapropriados pelo estado, terrenos adjacentes à linha adutora das águas do cabuçu. Disponível em https://www.al.sp.gov.br/norma/?id=136158. Acesso em jul. 2017

Decreto $\mathbf{n}^{0}$ 2.141 de novembro de 1911. Reorganiza o serviço sanitário do estado. Disponível em http://www.al.sp.gov.br/norma/?id=135510. Acesso em jul. $2017 .$.

.Decreto $n^{\circ}$ 2.918, de 09/04/1918. Dá execução ao código sanitário do estado de são paulo. Disponivel em http://www.al.sp.gov.br/norma/?id=134547. Acesso em jul. 2017

.Lei $\mathrm{n}^{\circ}$ 2.259, de 31/12/1927. Modifica as disposições do código sanitário, relativamente a construção de hospitais, casas de saúde e maternidade. Disponível em https://www.al.sp.gov.br/norma/?id=66551. Acesso em jul. 2017.

. LEI N. 2.484, DE 16 DE DEZEMBRO DE 1935. Dispõe sobre creação, annexação, desmembramento ou suppressão de município. Disponível em http://www.al.sp.gov.br/repositorio/legislacao/lei/1935/lei-2484-

16.12.1935.html. Acesso em jul. 2017

. decreto $n^{\circ} 4.641$, de 03/10/1929. Regulamenta a lei $n^{\circ} 2362$, de 14 de janeiro deste ano, que deu organização às prefeituras sanitárias de campos do jordão e guarujá. Disponível em https://www.al.sp.gov.br/norma/?id=132845. Acesso em: jul. 2017.

SPIRKINE, A. YAKHOT, O. Princípios do Materialismo Dialético. S. São Paulo: Estampa, 1975

SPOSITO, Maria. Encarnação Beltrão. Loteamentos fechados em cidades médias paulistas - Brasil. In: SPOSITO, E.; SPOSITO, M. E.; SOBARZO, O. (Org.). Cidades 
médias: produção do espaço urbano e regional. São Paulo: Expressão Popular, 2006. p. 175- 197

.. A cidade dentro da cidade. Uma edge city em São José do Rio Preto. In Scripta Nova Revista Eletrónica de Geografía Y Ciencias Sociales: Universidad de Barcelona, 2003. Disponível em: . SPOSITO, Maria Encarnação Beltrão; GOES, Eda Maria. Espaços fechados e cidades: insegurança urbana e fragmentação socioespacial. 1 ed. - São Paulo: Editora Unesp, 2013

SUNDFELD, Carlos Ari. A submissão das empresas estatais ao direito privado: uma definição histórica do STF. Boletim de Direito Administativo, n.5, p.286-290, maio, 1995.

.. O Estatuto da Cidade e Suas Diretrizes Gerais (art. $2^{\circ}$ ) )" in: Estatuto da Cidade - Comentários à Lei Federal 10.257 de 2001. DALLARI; A.A.; FERRAZ, S. (org.). $4^{\mathrm{a}}$ ed. São Paulo: Malheiros Editores, 2014. p. 47-61

SWYNGEDOUW, Erik; MOULAERT, Frank; RODRIGUEZ, Arantxa. Neoliberal urbanization in Europe: large-scale urban development projects and the new urban policy. Antipode, v. 34, n. 3, p. 542-577, 2002.

TIERNO. Roseane. Palestra sobre a MP 759 In: IAB-SP + IBDU DEBATEM MP-759, 2017, São 01 de fevereiro de 2017. IAB, São Paulo. Disponível em https://www.youtube.com/watch?v=9o8RTkTFvoI> Acesso em: 8 jul. 2017

TOMANIK, Raquel. Rural versus urbano: quais são as regras da disputa? Uma discussão a partir da aplicação do artigo 42-B do Estatuto da Cidade em Betim / MG. XVII ENANPUR - sessão temática 3: produção e gestão do espaço urbano, metropolitano e regional. São paulo, 2017.

UZZO, Karina et al. Retratos sobre a atuação da sociedade civil pelo direito à cidade: diálogo entre Brasil e França. 2006.

VILlAÇA, F. J. M. A Estrutura Territorial da Metrópole Sul Brasileira. 1978. Tese. [Doutorado em Geografia Física]. Departamento de Geografia da Faculdade de Filosofia, Letras e Ciências Humanas da Universidade de São Paulo. São Paulo. Espaço Intra-Urbano no Brasil. São Paulo. Studio Nobel. 2001

Uma contribuição para a história do planejamento urbano no Brasil. In: DEAK, C.; SCHIFFER, S. R. (orgs.). O processo de urbanização no Brasil. São Paulo: Editora da Universidade de São Paulo, 2004, p.167-243. 


\section{LISTA DE IMAGENS}

\section{1 - GRÁFICOS}

Gráfico 1 - Desigualdade social no golpe militar de 1964. SOUZA, P.H.G.F.; MEDEIROS, M. "Top Income Shares and Inequality in Brazil" in Sociologies in Dialogue. Revista da Sociedade Brasileira de Sociologia (ISSN 2447-2670) SID, Porto Alegre, v. 1, n. 1, p. 119-132, jul.-dez. 2015

Gráfico 2 - Total de Despesas Municipais em Urbanismo (Ribeirão Preto). Fundação SEADE, 2017. Disponível em http://www.imp.seade.gov.br/frontend/\#/tabelas . Acesso em 15 jul.2017 Gráfico 3 - Total de Despesas Municipais (Em Reais de 2016), Fundação SEADE. Disponível em http://www.imp.seade.gov.br/frontend/\#/tabelas . Acesso em 15 jul.2017

\section{II - FIGURAS}

Figura 1 - Núcleo urbano principal de Ribeirão Preto e núcleo colonial Antônio Prado em 1887. SILVA, Adriana Capretz Borges da. Imigração e Urbanização: o núcleo colonial Antônio Prado em Ribeirão Preto. 2002. Dissertação (Mestrado em Engenharia Urbana). DECiv/UFSCar, São Carlos.

Figura 2 - Histórico do registro de parcelamento do solo (1910 - 1939).

PREFEITURA MUNICIPAL DE RIBEIRÃO PRETO. Histórico do registro de parcelamento do solo com e sem registro de aprovação da prefeitura, a partir do ano de 1900. SERPLAN Secretaria de Planejamento e Gestão Pública de Ribeirão Preto, 2017

Figura 3 - Histórico do registro de parcelamento do solo (1910 - 1969)

PREFEITURA MUNICIPAL DE RIBEIRÃO PRETO. Histórico do registro de parcelamento do solo com e sem registro de aprovação da prefeitura, a partir do ano de 1900. SERPLAN Secretaria de Planejamento e Gestão Pública de Ribeirão Preto, 2017

Figura 4 - Proposta Viária e de Zoneamento Urbano do Plano Diretor de José de Oliveira Reis, em 1945. FIGUEIRA, Tânia Maria Bulhões. Produção social da cidade contemporânea. Análise dos Condomínios Urbanísticos e Loteamentos Fechados de Alto Padrão do Subsetor Sul de Ribeirão Preto/SP, v. 198, 2013 . p. 116

FIGUEIRA, Tânia Maria Bulhões. Produção social da cidade contemporânea. Análise dos Condomínios Urbanísticos e Loteamentos Fechados de Alto Padrão do Subsetor Sul de Ribeirão Preto/SP, v. 198, 2013 . p. 116

Figura 5 - Plano de vias de Ribeirão Preto - 1960

FIGUEIRA, Tânia Maria Bulhões. Produção social da cidade contemporânea. Análise dos Condomínios Urbanísticos e Loteamentos Fechados de Alto Padrão do Subsetor Sul de Ribeirão Preto/SP, v. 198, 2013.p. 117

Figura 6 - Parcelamentos Aprovados pela Prefeitura de Ribeirão Preto (1910 1989). PREFEITURA MUNICIPAL DE RIBEIRÃO PRETO. Histórico do registro de parcelamento do solo com e sem registro de aprovação da prefeitura, a partir do ano de 1900. SERPLAN - Secretaria de Planejamento e Gestão Pública de Ribeirão Preto, 2017 
Figura 7 - Eixo Sul e as mudanças provocadas pela L. 3349 de 1977.

FIGUEIRA, Tânia Maria Bulhões. Produção social da cidade contemporânea. Análise dos Condomínios Urbanísticos e Loteamentos Fechados de Alto Padrão do Subsetor Sul de Ribeirão Preto/SP, v. 198, 2013. P. 144

Figura 8 - Renda Per Capita nos setores censitários de 2000.

CELARINO, Andre. Ribeirão Preto-SP de 2000 a 2010: Poucas mudanças. O metafísico, Ribeirão Preto, Abr. 2013 ttps://ometafisico.wordpress.com/2013/04/22/ribeirao-preto-sp-de-2000-a-2010poucas-mudancas/\#comments. Acesso em 18 de julho de 2017.

Figura 9 - Renda Per Capita nos setores censitários de 2010. CELARINO, Andre. Ribeirão Preto-SP de 2000 a 2010: Poucas mudanças. O metafísico, Ribeirão $\quad$ Preto, $\quad$ Abr. 2013 ttps://ometafisico.wordpress.com/2013/04/22/ribeirao-preto-sp-de-2000-a-2010poucas-mudancas/\#comments. Acesso em 18 de julho de 2017.

Figura 10 - Divisão racial do município de Ribeirão Preto em 2010 CELARINO, Andre. Ribeirão Preto-SP de 2000 a 2010: Poucas mudanças. O metafísico, Ribeirão $\quad$ Preto, $\quad$ Abr. 2013 ttps://ometafisico.wordpress.com/2013/04/22/ribeirao-preto-sp-de-2000-a-2010poucas-mudancas/\#comments. Acesso em 18 de julho de 2017.

Figura 11 - Proporção de pessoas com 5 anos ou mais alfabetizadas em relação à população total por setores censitários (2010)

CELARINO, Andre. Ribeirão Preto-SP de 2000 a 2010: Poucas mudanças. O metafísico, Ribeirão $\quad$ Preto, $\quad$ Abr. 2013 ttps://ometafisico.wordpress.com/2013/04/22/ribeirao-preto-sp-de-2000-a-2010poucas-mudancas/\#comments. Acesso em 18 de julho de 2017.

Figura 12 - Relação entre Shoppings, Infraestrutura Viária e a Valorização do Solo. Fonte: Google Earth - Ribeirão Preto. Produção do autor.

Figura 13 - Macrozoneamento de Ribeirão Preto (2007).

RIBEIRÃO PRETO. Lei 2.157 de 8 de janeiro de 2007. Dispões sobre o parcelamento do solo. https://www.ribeiraopreto.sp.gov.br/J321/pesquisa.xhtml?lei=21377,

Figura 14- Mapa macrozoneamento de Ribeirão Preto (2012). Fonte: RIBEIRÃO PRETO. Prefeitura Municipal de Ribeirão Preto. Secretaria de Planejamento e Gestão Pública. Justificativa técnica do plano diretor. Ribeirão Preto: Sem Editora, 2014. 169 p. Disponível em: <https://www.ribeiraopreto.sp.gov.br/splan/planod/justificativa_tecnica.pdf $>$. Acesso em: 19 jul 2017.

Figura 15 - Mapa de Vazios Urbanos em Ribeirão Preto; Autor: Rodrigo Rissi Geraldi, Ribeirão Preto, 2016

Figura 16 - Pequenas Áreas Agrícolas X Grandes Empreendimentos Imobiliários. Fonte: Google Earth; CATI Escritório de Desenvolvimento Rural de Ribeirão Preto, 2017. Elaborado pelo autor. 
Figura 17 - Pequenas Propriedades Rurais no epicentro da Especulação Imobiliária - Zona Sul de Ribeirão Preto (Vila do Golfe)

Elaborada pelo autor, dez. 2015.

Figura 18 - Região do Shopping Iguatemi (2004) Elaborada pelo autor a partir de imagens do Google Earth, 2017. Elaborado pelo autor.

Figura 19 - Região do Shopping Iguatemi (2012) Elaborada pelo autor a partir de imagens do Google Earth, 2017. Elaborado pelo autor.

Figura 20 - Região do Shopping Iguatemi (2017) Elaborada pelo autor a partir de imagens do Google Earth, 2017. Elaborado pelo autor.

\section{III - TABELAS}

Tabela 1: Tipos normativos estaduais que mencionam a palavra "perímetro urbano" em Ribeirão Preto, no período oligárquico. Elaboração do autor.

Tabela 2 - Taxa de urbanização no Brasil (1940 - 1991). Instituto Brasileiro De Geografia E Estatística. Censos Demográficos. Rio de Janeiro. IBGE. 1920, 1930, 1940, 1950, 1960, 1970, 1980, 1991, 2000 e 2010.

Tabela 3 - Escala de Dominialidade. MARRARA, Thiago. "Bens públicos Domínio urbano Infra-estruturas." Editora Forum, 2007, p. 96

Tebela 4 - Tipos normativos municipais que mencionam a palavra "perímetro urbano" em Ribeirão Preto, no período entre 1930 e 1964. Fonte: Elaboração do autor

Tabela 5 - Tipos normativos municipais que mencionam a palavra "perímetro urbano" em Ribeirão Preto, no período entre 1964 e 1988. Fonte: Elaboração do autor

Tabela 6 - Estratificação das propriedades rurais em Ribeirão Preto (por área). Palestra ministrada na Associação de Engenharia, Arquitetura e Agronomia de Ribeirão Preto - Fórum Permanente de Debates "Ribeirão Preto do Futuro" em Abril de 2015.pelo Engo Agr $^{\circ}$ Luís Fernando F. Zorzenon

Tebela 7 - Proporção Área Urbana X Área Rural (1995-2000)

Palestra ministrada na Associação de Engenharia, Arquitetura e Agronomia de Ribeirão Preto - Fórum Permanente de Debates "Ribeirão Preto do Futuro" em Abril de 2015.pelo Eng" Agr" Luís Fernando F. Zorzenon 